UNIVERSIDADE DE BRASÍLIA

FACULDADE DE ARQUITETURA E URBANISMO (FAU)

PROGRAMA DE PESQUISA E PÓS-GRADUAÇÃO (PPG)

FELIPE PEREIRA NASCIMENTO

ESPECIFICAÇÃO DE SISTEMAS CONSTRUTIVOS INDUSTRIALIZADOS PARA EDIFICAÇÕES PÚBLICAS:

AVALIAÇÃO DE CONTRATAÇÕES PÚBLICAS DE PROJETO

BRASÍLIA - DF 
FELIPE PEREIRA NASCIMENTO

\title{
ESPECIFICAÇÃO DE SISTEMAS CONSTRUTIVOS \\ INDUSTRIALIZADOS PARA EDIFICAÇÕES PÚBLICAS: \\ AVALIAÇÃO DE CONTRATAÇÕES PÚBLICAS DE PROJETO
}

FELIPE PEREIRA NASCIMENTO

\begin{abstract}
Dissertação submetida à Faculdade de Arquitetura e Urbanismo da Universidade de Brasília como parte dos requisitos necessários para a obtenção do Grau de Mestre no Curso de Arquitetura e Urbanismo da Faculdade de Arquitetura e Urbanismo (FAU), Programa de Pesquisa e Pós-Graduação (PPG), linha de pesquisa Técnicas e Processos de Produção do Ambiente Construído (TAS).

Orientadora Prof. Dra. Raquel Naves Blumenschein.
\end{abstract}

\section{BRASÍLIA/DF}




\title{
UNIVERSIDADE DE BRASÍLIA \\ FACULDADE DE ARQUITETURA E URBANISMO \\ PROGRAMA DE PÓS-GRADUAÇÃO EM ARQUITETURA E \\ URBANISMO
}

\author{
ESPECIFICAÇÃO DE SISTEMAS CONSTRUTIVOS \\ INDUSTRIALIZADOS PARA EDIFICAÇÕES PÚBLICAS: \\ AVALIAÇÃO DE CONTRATAÇÕES PÚBLICAS DE PROJETO \\ ARQ. FELIPE PEREIRA NASCIMENTO
}

DISSERTAÇÃO DE MESTRADO SUBMETIDA AO PROGRAMA DE PÓS-GRADUAÇÃO EM ARQUITETURA E URBANISMO DA FACULDADE DE ARQUITETURA E URBANISMO DA UNIVERSIDADE DE BRASÍLIA, COMO PARTE DOS REQUISITOS NECESSÁRIOS PARA A OBTENÇÃO DO GRAU DE MESTRE EM ARQUITETURA E URBANISMO.

APROVADA POR:

Prof. ${ }^{a}$. RAQUEL NAVES BLUMENSCHEIN, Dr. ${ }^{\text {a }}$ (FAU/UnB) (Orientadora)

Prof. ${ }^{a}$. ROSA MARIA SPOSTO, Dr. ${ }^{\text {a }}$ (FT/UnB)

(Examinador Externo)

Prof. ${ }^{a}$ VANDA ALICE GARCIA ZANONI, Dr., ${ }^{a}$ (FAU/UnB) (Examinador Interno)

BRASÍLIA/DF, 26 DE JANEIRO DE 2018. 
FICHA CATALOGRÁFICA

NASCIMENTO, FELIPE PEREIRA

Especificação de sistemas construtivos industrializados para edificações públicas: avaliação de contratações públicas de projeto.

[Distrito Federal] 2018.

xvii, 140p., 210 x 297 mm (PPG-FAU/UnB, Mestre, Arquitetura e Urbanismo, 2018).

Dissertação de Mestrado - Universidade de Brasília. Programa de Pós-Graduação em

Arquitetura e Urbanismo.

Faculdade de Arquitetura e Urbanismo.

1. Sistemas Construtivos Industrializados 2. Planejamento

3. Obras Públicas 4. Inovação

I. FAU/UnB II. Título (série)

\section{REFERÊNCIA BIBLIOGRÁFICA}

NASCIMENTO, F. P. (2017). U Especificação de sistemas construtivos industrializados para edificações públicas: avaliação de contratações públicas de projeto. Dissertação de Mestrado em Arquitetura e Urbanismo. Programa de PósGraduação em Arquitetura e Urbanismo, Faculdade de Arquitetura e Urbanismo, Universidade de Brasília, Brasília, DF, 138p.

\section{CESSÃO DE DIREITOS}

AUTOR: Felipe Pereira Nascimento

TÍTULO: Especificação de sistemas construtivos industrializados para edificações públicas: avaliação de contratações públicas de projeto.

GRAU: Mestre ANO: 2018

É concedida à Universidade de Brasília permissão para reproduzir cópias desta dissertação de mestrado e para emprestar ou vender tais cópias somente para propósitos acadêmicos e científicos. O autor reserva outros direitos de publicação e nenhuma parte dessa dissertação de mestrado pode ser reproduzida sem autorização por escrito do autor.

Felipe Pereira Nascimento

QMSW 05, Lote 02, Bloco D, No 01, Sudoeste

70.680-500 Brasília - DF - Brasil

e-mail: felipen.arquitetura@gmail.com 


\section{DEDICATÓRIA.}

À minha família, pais, irmãos e noiva, que é meu porto seguro e minha fonte de energia.

Ao Brasil, meu país, e ao Maranhão, minha terra, meu torrão. Que as soluções inovadoras sejam cada vez mais presentes em suas realidades e que tragam o desenvolvimento necessário e condizente com suas respectivas grandezas. 


\section{AGRADECIMENTOS}

A DEUS, pela sua providência divina em minha vida através das realizações e das pessoas que ele colocou em meu caminho.

Aos meus Pais, Orlanir e Lourival, pelo carinho, dedicação e exemplo de humanidade e por suas orações carregadas de fé e amor.

Aos meus irmãos, Victor e Victoria, pelo incentivo e carinho.

À minha noiva, Christiana, pelo companheirismo, dedicação, paciência e por todo o suporte que me ofereceu ao longo desse processo.

À minha orientadora, Prof $f^{\mathrm{a}}$. Dr ${ }^{\mathrm{a}}$. Raquel Naves Blumenschein, por me acompanhar na travessia do portal da pesquisa acadêmica, por ter confiado neste trabalho e incentivado a busca pela transformação através do conhecimento e pela compreensão e solicitude ofertados a mim.

Aos professores do PPGFAU/UnB, que contribuíram para a minha formação durante o curso de mestrado.

A todos os colegas discentes da PPGFAU/UnB que estiveram ao meu lado ao longo do curso, em especial aos amigos Bruno Guimarães e Mariana Guimarães pelas experiências e informações compartilhadas.

Às professoras Rosa Sposto e Vanda Zanoni, que compõem a Banca de avaliação desse trabalho, por terem aceitado participar do processo de construção dessa pesquisa e pelas valiosas contribuições para o seu prosseguimento.

À CAPES por ter viabilizado a realização desse trabalho através do provimento do suporte financeiro.

Sem dúvida, a conclusão de um trabalho acadêmico é uma vitória que está associada às pessoas que estiveram presentes ao longo do caminho, o que torna impossível conquistá-la sozinho. Muito obrigado a todos. 
O importante para o governo não é fazer coisas que os indivíduos já estão fazendo, e fazê-las um pouco melhor ou um pouco pior; mas fazer aquelas coisas que no momento não são feitas de forma alguma." John Maynard Keynnes. 


\section{RESUMO}

O presente trabalho apresenta uma análise sobre o processo de concepção e tomada de decisão que define o objeto da contratação de obras para edificações públicas, sobretudo quanto à escolha dos sistemas construtivos a serem utilizados como solução de projeto dos empreendimentos públicos.

O trabalho propõe o desenvolvimento de uma ferramenta de avaliação destinada a mapear a presença de fatores determinantes para a especificação de sistemas construtivos industrializados como soluções de projeto nos processos de licitação, a fim de identificar entraves e propor diretrizes para a intensificação do uso desses sistemas.

O desenvolvimento da pesquisa é realizado por meio de estudos bibliográficos sobre o processo de planejamento e inovação na Indústria da Construção (IC), o processo de concepção e contratação de obras públicas e sobre conceitos e aspectos relacionados à construção industrializada; e por meio da análise da legislação pertinente à contratação pública de obras públicas e serviços de engenharia.

Ao longo do trabalho são apresentados estudos de casos correspondentes à aplicação da ferramenta de avaliação, desenvolvida a partir da fundamentação teórica e da análise de instrumentos de contratação de projetos e obras para a concepção e execução de edificações públicas, tais como editais e termos de referência de licitações.

Os estudos bibliográficos têm objetivo de fundamentar o desenvolvimento da ferramenta de pesquisa e a seleção dos estudos de caso. A ferramenta de pesquisa permitirá caracterizar os processos de concepção e contratação de projetos e obras para edificações públicas e mapear os critérios e premissas determinantes na materialização dos objetos contratados.

O resultado principal do trabalho corresponde à ferramenta de pesquisa, que permite avaliar o processo de concepção do objeto e as decisões tomadas nesse processo, além de identificar se as premissas fundamentais para promoção da industrialização da IC foram contempladas na fase de planejamento da obra pública.

A partir dos resultados obtidos pela aplicação da ferramenta de pesquisa nos estudos de caso e da sua análise sob a luz dos estudos bibliográficos a respeito do processo de industrialização da construção civil, o trabalho tem como resultado final a identificação dos entraves e a proposição de diretrizes para a utilização de sistemas construtivos industrializados em obras para edificações públicas. 


\begin{abstract}
This research presents a reflection about the process of conception and decision making that defines the object of the contracting of works for public buildings, mainly to the choice of the constructive systems to be used as solution of the project of the public enterprises.

The research also proposes the development of an evaluation tool aimed at a presence of determining factors for a choice of industrialized construction systems as solutions to design in the bidding processes, in order to identify barriers and propose guidelines for an intensification of the use systems.

The development of research carried out by means of bibliographical studies on the planning and innovation process in the Construction Industry $(\mathrm{CI})$, the process of conception and contracting of public works and on concepts and related to the industrialized construction. For this purpose, a bibliographic review was carried out related to themes and analysis of legislation pertinent to the public procurement of public works and engineering services.

Throughout the work, they were developed from the theoretical foundation and the analysis of instruments of contracting of projects and works for the design and execution of public buildings, such as documents of public contractions and terms of reference.

The bibliographic studies have an objective to base the development of the research tool and a selection of the case studies. Already the research tool in search of processes of conception and contracting of projects and works for elaboration of accounts and mapping the criteria and determinant premises in the materialization of the objects contracted.

The main result of the work corresponds to the research tool, which allows to evaluate the process of conception of the object and the decisions taken in this process, besides identifying if the fundamental premises to promote the industrialization of $\mathrm{CI}$ were contemplated in the planning phase of the public works.

From the results obtained by the application of the research tool in the case studies and their analysis in the light of bibliographical studies on the process of industrialization of civil construction, the work has the final result the identification of the obstacles and the proposal of guidelines for the use of industrialized construction systems in works for public buildings.
\end{abstract}




\section{SUMÁRIO}

1 INTRODUÇÃO .......................................................................................... 1

1.1 Delimitação da Pesquisa (Problema a ser estudado) ............................................... 6

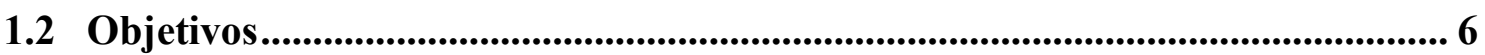

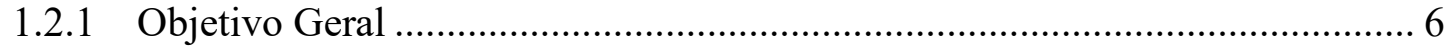

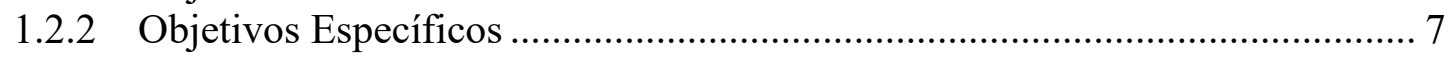

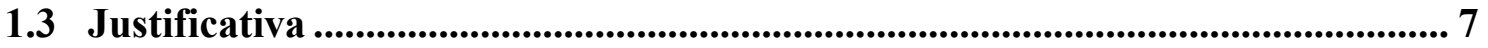

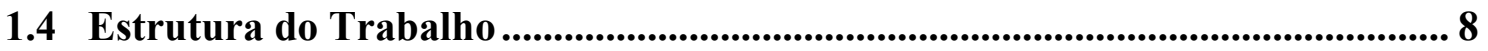

2 INOVAÇÃO NA CPIC E PLANEJAMENTO DE OBRAS PÚBLICAS......... 10

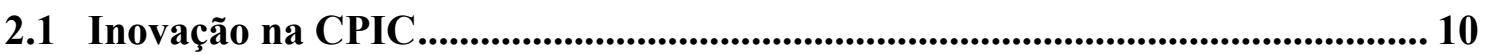

2.1.1 Processos de inovação na CPIC e seus vetores de influência.......................... 12

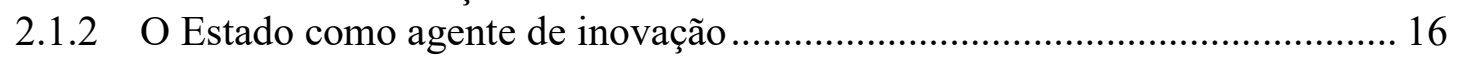

2.1.3 Estado como financiador de inovação na CPIC ............................................. 17

2.2 Planejamento de Obras Públicas .................................................................. 19

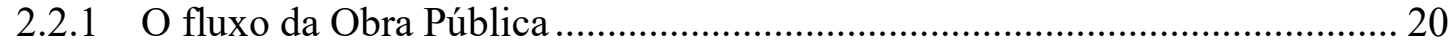

2.2.2 Legislação Pertinente................................................................................... 21

2.2.3 Contratação de Serviços Técnicos (Projeto e Planejamento) .......................... 25

2.2.4 Processo de Planejamento e tomadas de decisão............................................ 27

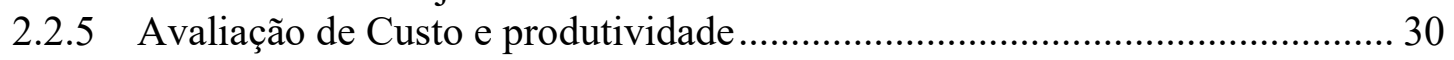

2.2.6 Sustentabilidade como requisito de planejamento de edificações públicas. .. 32

2.3 Síntese analítica do capítulo............................................................................ 33

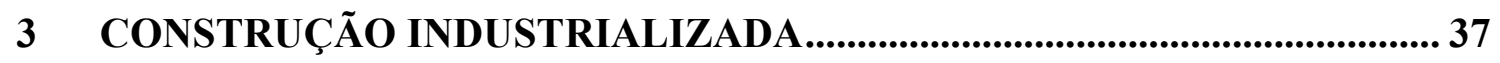

3.1 Conceito de Construção Industrializada ....................................................... 37

3.2 Aspectos do processo construtivo industrializado ...........................................45

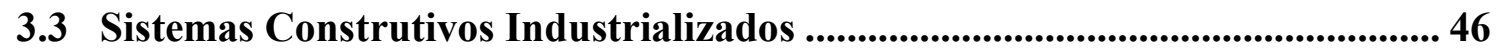

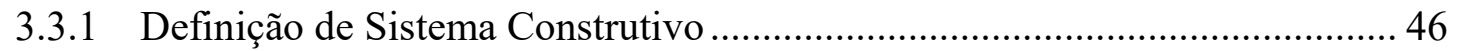

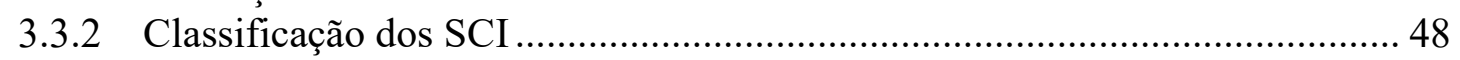

3.4 Principais Sistemas Construtivos Industrializados utilizados no Brasil ......... 48

3.4.1 Sistemas Construtivos em Aço: ................................................................. 48

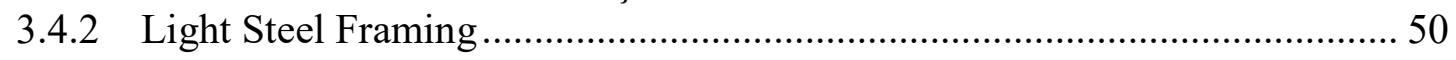

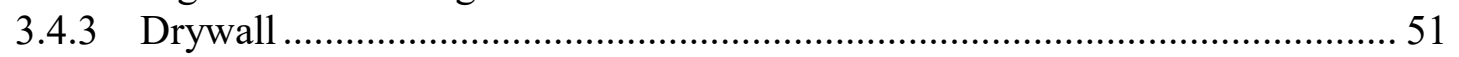

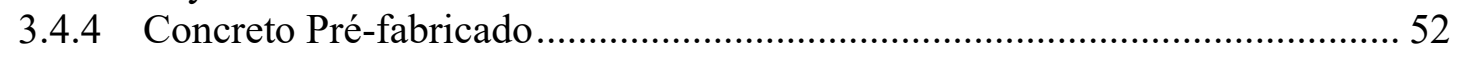

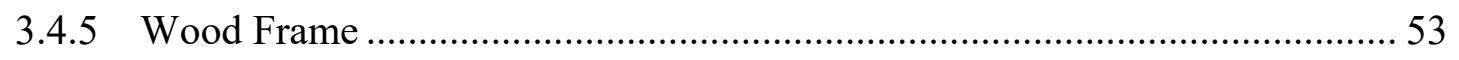

3.5 Modelo de Construção Industrializada (Base Pesquisa).................................... 56

3.5.1 Finalidades e requisitos das áreas do modelo de Construção Industrializada 57

3.5.2 O modelo de construção industrializada dentro da obra Pública ................... 59 


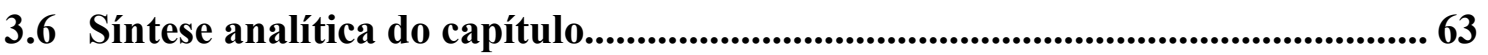

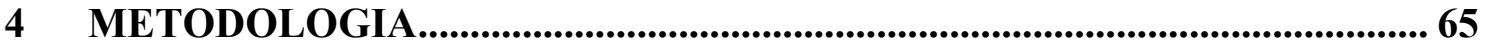

4.1 Ferramenta Pesquisa - Avaliação de Instrumentos de Licitação ..................... 65

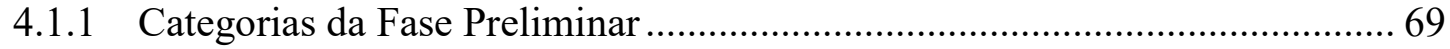

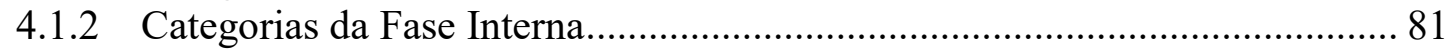

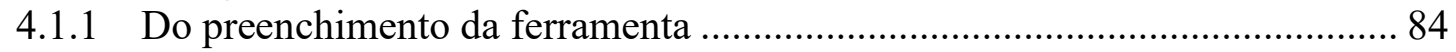

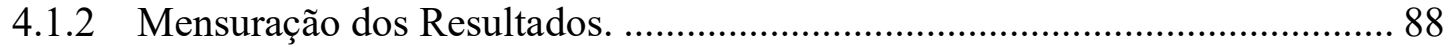

4.2 Estudo de Caso

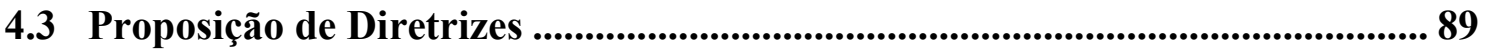

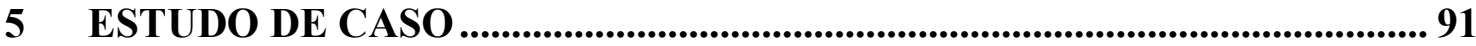

5.1 Disposições iniciais......................................................................................................... 91

5.2 Aplicação Ferramenta (01) - Identificação de Critérios e Diretrizes da Construção Industrializada ................................................................................... 92

5.2.1 Modalidade Concurso de Projeto ................................................................ 93

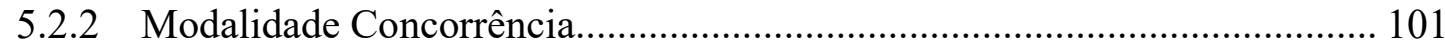

5.2.3 Modalidade Tomada de Preços ................................................................... 110

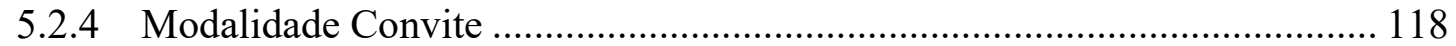

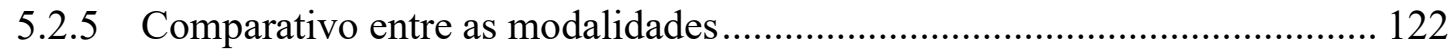

5.2.6 Avaliação dos resultados por tipo............................................................ 126

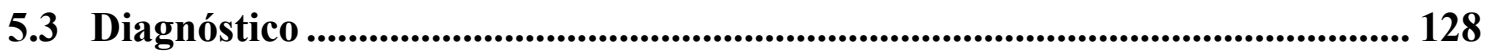

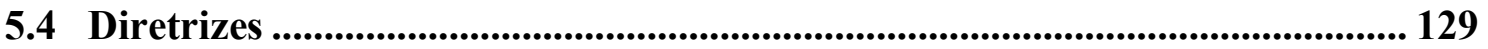

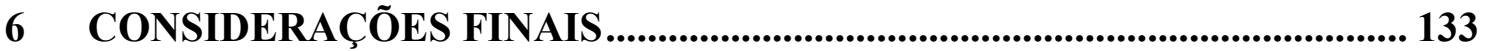

6.1 Observações sobre a execução da pesquisa .......................................................... 137

6.2 Sugestões para pesquisas futuras ............................................................................. 137

REFERÊNCIAS BIBLIOGRÁFICAS ................................................................... 139

INSTRUMENTOS DE LICITAÇÃO ................................................................ 147

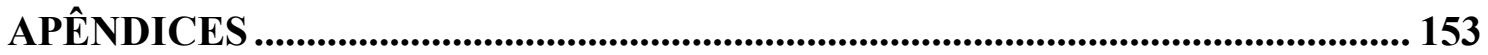




\section{LISTA DE FIGURAS}

FIGURA 1. CADEIA PRODUTIVA COMO ORGANISMO VIVO. FONTE:

BLUMENSCHEIN (2004)

FIGURA 2. FASES DA OBRA PÚBLICA. FONTE: TCU (2013)...

FIGURA 3. NÍVEIS DE INDUSTRIALIZAÇÃO. FONTE: ADAPTADO DE MC DONNELL (1999) 40

FIGURA 4. PROCESSO DE CONSTRUÇÃO INDUSTRIALIZADA. FONTE: ADAPTADO

DE LESSING (2006) .42

FIGURA 5. MODELO DE CONSTRUÇÃO INDUSTRIALIZADA ADAPTADO. .57

FIGURA 6: DETALHAMENTO DO MODELO CONSTRUÇÃO INDUSTRIALIZADA....... 59

FIGURA 7. FASE PRELIMINAR OBRA PÚBLICA X ÁREAS DO PROCESSO DE CI....... 60

FIGURA 8. FASE INTERNA OBRA PÚBLICA X ÁREAS DO PROCESSO DE CI. ............. 61

FIGURA 9. FASE EXTERNA OBRA PÚBLICA X ÁREAS DO PROCESSO DE CI. ............61

FIGURA 10. FASE CONTRATUAL OBRA PÚBLICA X ÁREAS DO PROCESSO DE CI. . 62

FIGURA 11: FASE POSTERIOR OBRA PÚBLICA X ÁREAS DO PROCESSO DE CI....... 62

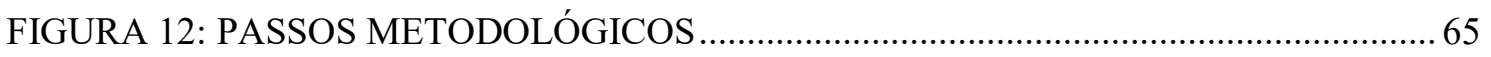

FIGURA 15 - ÁREAS DO MODELO DE CONSTRUÇÃO INDUSTRIALIZADA NA FASE

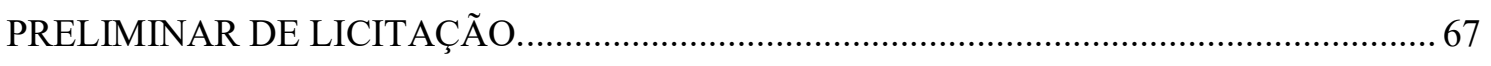

FIGURA 16 - RACIOCÍNIO FERRAMENTA DE PESQUISA …............................................. 67 


\section{LISTA DE GRÁFICOS}

GRÁFICO 1: RESULTADOS - ASPECTOS TÉCNICOS / MODALIDADE

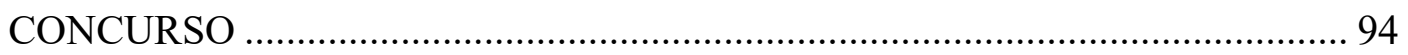

GRÁFICO 2: ASPECTOS AMBIENTAIS / MODALIDADE CONCURSO ………..... 98

GRÁFICO 3: RESULTADOS - ASPECTOS SOCIOECONÔMICOS /

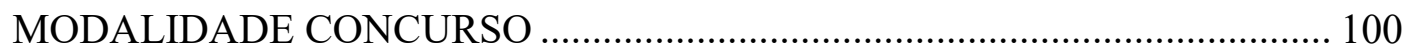

GRÁFICO 4: RESULTADOS - ASPECTOS TÉCNICOS / MODALIDADE

CONCORRÊNCIA

GRÁFICO 5: RESULTADOS - ASPECTOS AMBIENTAIS / MODALIDADE

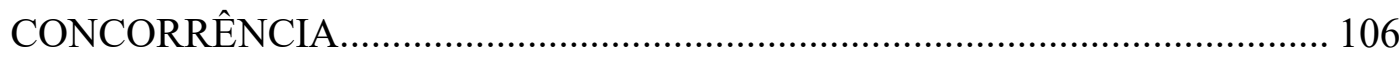

GRÁFICO 6: RESULTADO / ASPECTOS SOCIOECONÔMICOS - MODALIDADE

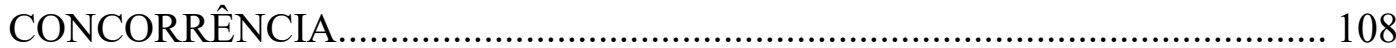

GRÁFICO 7: RESULTADOS - ASPECTOS TÉCNICOS / MODALIDADE

TOMADA DE PREÇOS.

GRÁFICO 8: RESULTADOS / ASPECTOS TÉCNICOS - MODALIDADE

TOMADA DE PREÇOS

GRÁFICO 9: RESULTADOS - ASPECTOS SOCIOECONÔMICOS /

MODALIDADE TOMADA DE PREÇOS

GRÁFICO 10: RESULTADO / ASPECTOS TÉCNICOS - MODALIDADE

CONVITE

GRÁFICO 11: RESULTADOS / ASPECTOS SOCIOECONÔMICOS -

MODALIDADE CONVITE

GRÁFICO 12: COMPARATIVO ENTRE MODALIDADES / AVALIAÇÃO

ASPECTOS TÉCNICOS

GRÁFICO 13: COMPARATIVO ENTRE MODALIDADES / AVALIAÇÃO

ASPECTOS AMBIENTAIS.

GRÁFICO 14: COMPARATIVOS ENTRE MODALIDADES / AVALIAÇÃO

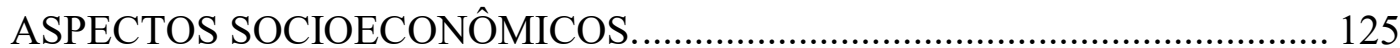

GRÁFICO 15: PANORAMA DOS RESULTADOS POR TIPO_................................. 126

GRÁFICO 16: PANORAMA DOS RESULTADOS POR MODALIDADE............... 127 


\section{LISTA DE TABELAS}

TABELA 1. FERRAMENTA PESQUISA PARTE 01 68

TABELA 2. FERRAMENTA PESQUISA - ESTRUTURA PARTE 02 68

TABELA 3 - FORMAÇÃO CRITÉRIOS DA CATEGORIA ASPECTOS TÉCNICOS. 70

TABELA 4 - FORMAÇÃO CRITÉRIOS DA CATEGORIA ASPECTOS AMBIENTAIS

TABELA 5 - FORMAÇÃO CRITÉRIOS DA CATEGORIA ASPECTOS SOCIOECONÔMICOS 76 79

TABELA 7 - CATEGORIAS REFERENTES AO COMPARTILHAMENTO DE INFORMAÇÕES. 84

TABELA 8 - FERRAMENTA DE PESQUISA 01 85

TABELA 9. TABELA COMPLEMENTAR 01 - RESULTADO POR MODALIDADE. 86

TABELA 10. TABELA COMPLEMENTAR 02 - COMPARATIVO ENTRE TOTAIS

DAS MODALIDADES 87 


\section{LISTA DE QUADROS}

QUADRO 1: DEFINIÇÕES DE CONSTRUÇÃO INDUSTRIALIZADA.................... 44

QUADRO 2: ATRIBUTOS E REQUISITOS DOS SCI'S ......................................... 54

QUADRO 3: LISTA DE ENTIDADES CONTRATANTES - MODALIDADE

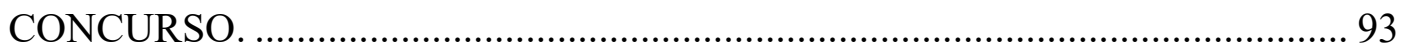

QUADRO 4: LISTA DE ENTIDADES CONTRATANTES - MODALIDADE CONCURSO.

QUADRO 5: LISTA DE ENTIDADES CONTRATANTES - MODALIDADE TOMADA DE PREÇO.

QUADRO 6: LISTA DE ENTIDADES CONTRATANTES - MODALIDADE CONVITE 


\section{LISTA DE ABREVIAÇÕES}

ABDI - Associação Brasileira de Desenvolvimento Industrial

ABNT - Associação Brasileira de Normas Técnicas

ACV - Avaliação de Ciclo de Vida

BIM - Building Information Modeling

BSC - Balanced Score Card

BNDES - Banco Nacional de Desenvolvimento Econômico e Social

CBCA - Centro Brasileiro de Construção em Aço

CPIC - Cadeia Produtiva da Indústria da Construção

IAB-BR - Instituto de Arquitetos do Brasil - Diretório Nacional

IAB-DF - Instituto de Arquitetos do Brasil - Diretório do Distrito Federal

IC - Indústria da Construção

IN - Instrução Normativa

IBGE - Instituto Brasileiro de Geografia Estática

LSF - Light Steel Framing

MCDA - Multicriterion Decision Aid

MCMV - Minha Casa Minha Vida

MDIC - Ministério do Desenvolvimento Industrial, Comércio Exterior e Serviços

MMC - Métodos Modernos de Construção

MPOG - Ministério do Planejamento, Orçamento e Gestão

NBR - Norma Brasileira

PAC - Programa de Aceleração do Crescimento

P\&D - Pesquisa e Desenvolvimento

PIB - Produto Interno Bruto

PROCEL - EDIFICA - Programa Nacional de Eficiência Energética em

Edificações

RDC - Regime Diferencial de Contratação

SINAT - Sistema Nacional de Avaliações Técnicas

SCI - Sistemas Construtivos Industrializados

SEAP - Secretaria de Estado da Administração e Patrimônio

TCU - Tribunal de Contas da União

TI - Tecnologia da Informação 


\section{INTRODUÇÃO}

A Construção Civil corresponde a uma das principais atividades econômicas do país, e cumpre um papel importante na construção do desenvolvimento econômico e social de uma nação de diversas formas, seja pela materialização de uma infraestrutura, seja pela produção de bens imobiliários, seja pela capacidade de gerar emprego.

O conceito de Cadeia Produtiva da Indústria da Construção Civil (CPIC) parte da premissa de articulação progressiva de um conjunto de atividades que se relacionam como elos distintos de uma corrente. A CPIC pode ser apresentada como uma composição formada por três grupos industriais básicos, representando os macroelos da cadeia (a cadeia ou indústria de suprimentos, a cadeia principal ou indústria de processos e a cadeia ou indústria auxiliar), que por sua vez são compostos por microelos (agentes e atividades). (MDIC. apud BLUMENSCHEIN, 2004).

Filha et al. (2010) apresenta uma segunda classificação da CPIC, que a divide em três subsetores - materiais de construção, edificações e construção pesada. Observa-se que essa classificação, embora incompleta por não contemplar a cadeia auxiliar, cabe dentro da anterior, sendo que a indústria de materiais de construção equivale à cadeia de suprimentos e as cadeias de edificações e de construção pesada podem ser consideradas uma divisão macro dos produtos da cadeia principal.

Dessa forma, a cadeia de suprimentos corresponde às empresas e indústrias fornecedoras de insumos (materiais, componentes, elementos e sistemas), a cadeia de processos ou principal é composta pela indústria de produção de edificações e engenharia (ou construção) pesada, ao passo que a cadeia auxiliar é responsável pela produção de informação e pesquisa - o que inclui serviços especializados de projeto de arquitetura e engenharias - das cadeias de insumo e principal, sendo considerada responsável também pela logística e transporte (BLUMENSCHEIN, 2004).

A CPIC é caracterizada pela alta complexidade do seu processo de construção uma vez que integra um número grande de atores com especialidades e níveis de formação e qualificação diversos. Essa indústria também apresenta forte segmentação da cadeia auxiliar e da cadeia de suprimentos, que impacta direta e negativamente na obtenção da padronização de produtos e ações, além da lenta absorção de inovação (BLUMENSCHEIN, 2004).

Fabrício (2002) trata a singularidade como característica natural do produto edifício da CPIC, e a vincula às limitações existentes quanto à padronização e a ampliação das 
escalas de produção dessa indústria. Destaca ainda a construção como um processo produtivo manufatureiro, devido à divisão de tarefas e ao processo de transformação que ela implica, e intensivo em mão de obra; bem como aponta o forte caráter social desse produto ao interagir com o meio ambiente urbano e com a qualidade de vida das pessoas.

Observa-se, porém, que a importância social da CPIC vai muito além da influência direta de uma edificação no meio urbano e nas pessoas que ocupam ou transitam em suas mediações, uma vez que o ciclo de uma obra resulta em diferentes impactos e efeitos.

Esses impactos e efeitos podem ser observados desde a extração de matérias primas para produção de insumos, resultando na modificação da paisagem e do meio ambiente, passando pela importância estratégica do setor para o mercado de trabalho e suas implicações econômicas chegando até ao desenvolvimento de novas tecnologias e soluções aplicadas em materiais, componentes e sistemas.

O ciclo de produção dos empreendimentos da CPIC também é caracterizado por longos prazos, ainda que se configurem de maneira temporária, já que o sistema de produção é montado para a materialização de um determinado produto e se desfaz após a sua conclusão (FABRÍCIO, 2002). Esse grande período de tempo deixa o empreendimento suscetível a variações de ordem econômica, que podem, inclusive, inviabilizar a continuidade das atividades e a conclusão das obras.

Peralta (2002) aponta a Indústria da Construção (IC) brasileira como uma das indústrias mais importantes para a economia nacional e observa que a sua relevância contrasta com o atraso desse setor em relação a outros setores industriais, sendo esse atribuído às peculiaridades da IC no Brasil, tais como o lento desenvolvimento tecnológico, a baixa eficiência produtiva e o baixo nível de qualidade do produto final.

Filha et al. (2010) ressalta a importância do desenvolvimento da cadeia da construção civil para a superação de problemas históricos do Brasil, tais como o Déficit Habitacional e a necessidade de infraestrutura. Ressalta-se também a sua influência em outras atividades industriais devido à ampla necessidade de insumos e complementos, a exemplo da demanda por bens de capital e embalagens.

A relação direta existente entre a economia nacional e a produção da CPIC também pode ser constatada pela análise dos resultados do Produto Interno Bruto (PIB) do país e da construção no período entre 2004 e 2016, onde os números positivos da construção civil foram acompanhados pelo crescimento econômico nacional na maioria dos anos.

No boletim estatístico disponibilizado pela Câmara Brasileira da Indústria da Construção (CBIC), que aborda o histórico do desempenho econômico da Indústria da 
Construção entre os anos 2000 e 2014, a IC apresentou taxas reais de crescimento de 9,1\% em 2007, 4,8\% em 2008, 7,5\% em 2009 (ano em que o PIB nacional indicou uma leve recessão de $0,2 \%$ e e 13,1\% em 2010, reafirmando que o início do ciclo virtuoso se deu em 2007 (CBIC, 2015).

Esse estudo da CBIC (2015) também mostra que foi em 2008 que o crescimento da indústria da construção foi consolidado, sendo assegurado por meio de políticas anticíclicas, que tiveram como objetivo reduzir os impactos da crise financeira originada nos Estados Unidos na economia nacional.

Entre essas políticas citam-se: a desoneração do Imposto sobre Produtos Industrializados nos materiais de construção, aumento de aportes financeiros por parte do Banco Nacional de Desenvolvimento Econômico e Social (BNDES), expansão do crédito imobiliário, investimento em programas públicos como o PAC (Programa de Aceleração do Crescimento) e o Minha Casa Minha Vida (MCMV).

Durante o período de concentração do crescimento econômico da construção civil, entre os anos de 2007 e 2013, observou-se a indústria da construção sem a devida capacidade para atender plenamente a forte demanda desse intervalo devido a diversos fatores.

Entre esses fatores destacam-se as condições artesanais da construção tradicional e o baixo índice de produtividade da cadeia principal, além das altas taxas de desperdício e sobrepreço nas aquisições de insumos e contração de serviços. Uma das principais consequências desse fenômeno foi o aumento do custo das obras.

O ano de 2010 marca o pico do crescimento econômico da construção na última década no Brasil. No entanto, a análise da série histórica permite perceber que em 2012 o setor da construção passa a ter uma tendência de estabilização, ao apresentar a taxa de crescimento efetivo de apenas 2,8\% frente aos 8,3\% de 2011 e 13,1\% relativo a 2010.

Apesar do ano de 2013 registrar crescimento maior que 2012, a uma taxa de 4,7\%, o ano de 2014 marca uma virada em sentido contrário para a construção civil, tornando os sinais de estagnação e posterior recessão econômica do setor mais evidentes ao apresentar uma retração de 2,6\% (CBIC, 2015).

O período de recessão iniciado em 2014 é agravado nos anos posteriores, 2015 e 2016, devido ao esgotamento das políticas anticíclicas e sua substituição por um pacote econômico caracterizado pela austeridade fiscal a fim de recuperar o equilíbrio das contas públicas, sobretudo do governo federal. Esse período pode ser caracterizado pela queda 
nas contratações de novas obras e na redução de investimentos, além do impacto em aspectos sensíveis, como a redução das taxas de emprego e ocupação.

Apesar da condição de manufatura da CPIC, vinculada à divisão e especialização das tarefas na produção da obra, e da importância econômica e social dessa indústria perante a economia nacional, o seu modo de produção ainda é caracterizado pela utilização de técnicas artesanais em atividades fundamentais, tais como a execução dos sistemas construtivos estruturais e de vedação com a utilização de técnicas tradicionais. Esse modo de produção implica em uma defasagem tecnológica e na qualidade dos produtos abaixo da almejada, indicando a necessidade de inovação da CPIC.

Os altos impactos ambientais da CPIC também tem sido objeto de discussão no âmbito da sustentabilidade ambiental. Ao longo de todo o processo construtivo de uma obra justifica-se a inovação dessa indústria, considerando desde a adequação da origem, por meio do processo de compra sustentável e certificação dos insumos, até o processo de desconstrução e descarte de materiais e componentes das edificações.

No estudo sobre o processo de inovação da CPIC, Blumenschein (2004) destaca a importância da compreensão dos seus vetores de influência apontando a necessidade de estudos que identifiquem como que mudanças são geradas e integradas ao processo de produção e aos produtos. A autora também apresenta alguns desses vetores, com destaque para a demanda, entendida como força propulsora de novos produtos e processos, além de retratar a necessidade de identificar os agentes integrantes da cadeia capazes de fazer a catalisação do processo de inovação.

Considerando a importância de identificar os vetores de influência e os agentes com potencial de trabalhar como catalisadores do processo de inovação, a presente pesquisa considera a necessidade de identificar os setores locomotivos da indústria da construção civil e as suas necessidades mais urgentes, para que se estabeleça uma estratégia de inovação para essa indústria. Os setores locomotivos são aqui entendidos como as atividades econômicas mais relevantes dentro da CPIC e que, por isso, possuem maior capacidade de ação e sustentação do processo de inovação.

IBGE (2017) aponta os setores de construção de edifícios e de obras para infraestrutura como os mais importantes na geração de valor da CPIC, com 46,7\% e 33,9\% respectivamente. O estudo ainda demonstra a importância das contratações públicas para a indústria da construção civil, que corresponderam a 30,6\% do total das construções em 2015. 
Esses dados revelam quais são os setores locomotivos dentro da CPIC, que possuem a capacidade de induzir transformações no modo de produção de toda a cadeia e que podem agir como vetores de influência no processo de inovação dessa cadeia.

A relação direta entre o agravamento da recessão econômica na indústria da construção e a redução dos investimentos públicos, bem como da sua demanda, e a taxa de participação das contratações públicas no PIB da construção civil reafirmam a importância do setor público para o desenvolvimento da CPIC. Isso demonstra a importância de analisar todo o processo que define uma obra pública para que se identifiquem as possibilidades de inovação da CPIC por esse setor.

Para Filha et al. (2009), a expansão da construção civil depende da construção industrializada. Em ABDI (2016), a industrialização é apresentada como o mais elevado estágio de racionalização dos processos construtivos e possibilita melhores condições de controle de qualidade e adoção de novas tecnologias.

Embora seja apenas uma parte do processo de industrialização da construção, a utilização de sistemas construtivos industrializados é considerada como uma resposta para as deficiências apresentadas pela CPIC - a exemplo da baixa produtividade, longo período de execução e a consequente suscetibilidade a variações econômicas, alto índice de desperdício e a baixa qualidade do produto.

Devido aos atributos dos sistemas construtivos industrializados, estes podem ser considerados como uma importante forma de alcançar a inovação necessária à indústria da construção civil.

No entanto, é perceptível que a utilização desses sistemas ainda é menor que a capacidade de produção existente no Brasil e das necessidades produtivas do país, prevalecendo ainda no cenário nacional a utilização dos sistemas construtivos tradicionais. Dessa forma, é necessário identificar meios de disseminação da utilização desses sistemas a fim de promover a inovação da indústria da construção.

A partir do entendimento do Setor Público como agente de inovação, devido a sua capacidade de investimento e de demanda, e da utilização de sistemas construtivos industrializados na correção de problemas da indústria da construção, tais como a baixa produtividade e qualidade, compreende-se que as obras públicas podem auxiliar no processo de inovação da IC através da intensificação da utilização desses sistemas.

Dessa forma, é necessário compreender as etapas que envolvem a materialização de uma obra pública a fim de identificar os fatores que determinam a tomada de decisão quanto à utilização de sistemas construtivos industrializados, devendo ser dispensada 
maior atenção à etapa de planejamento preliminar, onde ocorre a definição e concepção do objeto e há maior possibilidade de sua modificação com menores custos.

Vale destacar que está em curso a discussão de mudanças na legislação referente ao processo de aquisições e contratação de obras e serviços pela administração pública. A edição de uma nova lei geral de licitações, é bastante oportuna uma reflexão sobre o processo de planejamento inicial dos empreendimentos públicos, abordado de forma insuficiente na legislação atual, que destina maior atenção ao momento posterior destinado ao processo de contratação das obras.

\subsection{Delimitação da Pesquisa (Problema a ser estudado)}

O setor público, apesar de ser um importante agente econômico para o dinamismo da IC devido à grande capacidade de gerar demanda, apresenta, no geral, uma carência técnica no quadro de pessoas responsáveis por projetos e planejamento das obras que deverão atender às suas necessidades. Essa carência técnica acaba por tornar frequente a contração dos projetos técnicos por meio do processo licitatório próprio, que antecede a licitação das obras.

Porém, vale destacar que, mesmo quando a concepção da edificação fica a cargo de um terceiro, cabe à entidade pública definir as diretrizes e os requisitos a serem atendidos pelo objeto contratado, sendo que essas determinações devem estar devidamente dispostas nos instrumentos que compõem o processo licitatório, o que torna a entidade contratante responsável pelas decisões preliminares quanto as características desse objeto.

Dessa forma, a pesquisa tem como foco a identificação dos fatores determinantes para a adoção de sistemas construtivos industrializados como solução técnica dentro do processo de concepção e planejamento de obras para edificações públicas. Foca-se nas situações em que essas atividades são realizadas de maneira indireta por meio da contratação pelo processo de licitação; tendo como centro de atuação a avaliação dos instrumentos que compõem esse processo - tais como editais e termos de referência.

\subsection{Objetivos}

\subsubsection{Objetivo Geral}

O objetivo geral da pesquisa consiste em desenvolver uma ferramenta capaz de avaliar os documentos que formalizam processos de licitação - editais e termos de referência - para contratação de projetos técnicos para o setor público quanto à presença de fatores determinantes para escolha de sistemas construtivos industrializados como soluções técnicas para obras de edificações públicas. 


\subsubsection{Objetivos Específicos}

A partir do objetivo geral proposto, a pesquisa tem como objetivos específicos:

- Identificação das incompatibilidades entre o processo de planejamento de obras públicas previsto na legislação pertinente e a construção industrializada;

- Identificação dos entraves para a adoção dos sistemas construtivos industrializados em obras públicas, na fase de planejamento preliminar;

- Proposição de diretrizes para o planejamento de obras públicas adequado ao processo de construção industrializada.

\subsection{Justificativa}

A escassez dos recursos públicos, associado à crescente demanda por serviços prestados pelo Estado, tem pressionado a busca por uma gestão mais eficiente desses recursos por parte da Administração Pública a fim de evitar desperdícios e melhorar a qualidade e a efetividade dos serviços prestados.

Da mesma forma, a condição de escassez dos recursos naturais também tem avançado consideravelmente, se tornando uma preocupação crescente, principalmente quando relacionado a sistemas de produção com grande capacidade de transformação e degradação ambiental, como é o caso da Indústria da Construção em toda a sua cadeia produtiva.

A condição atual de defasagem tecnológica e baixa produtividade, associada ao elevado grau de manufatura da IC tem contribuído para o fraco desempenho quanto às questões de sustentabilidade ambiental e social, refletidas no alto índice de desperdício e de impactos ambientais e pelas condições de trabalho e nível de qualificação da mão de obra utilizada nessa indústria.

Identifica-se, portanto, a necessidade de inovação na IC, que por sua vez deve ser realizada por meio de agentes catalisadores que tenham relevância e poder transformador a fim de garantir maior eficiência e velocidade nesse processo de mudança, a exemplo das obras públicas. O amplo espectro de serviços ofertados pelo Estado, o torna um importante agente econômico capaz de influenciar a demanda por soluções inovadoras.

Dessa forma a pesquisa parte da hipótese de que determinados fatores relacionados à viabilidade técnica, ambiental e socioeconômica - tais como a produtividade, qualidade, sustentabilidade e o custo - não são devidamente considerados pelos processos de contratação pública, ainda que a legislação pertinente a essas contratações exija de forma genérica, a atenção aos princípios da economicidade, eficiência e sustentabilidade. 
A pesquisa parte ainda da premissa de que ao considerar os fatores citados acima durante o planejamento preliminar do objeto da obra pública, as decisões quanto à escolha dos sistemas construtivos tendem a considerar as soluções relacionadas ao processo de industrialização da construção.

\subsection{Estrutura do Trabalho}

O presente trabalho está organizado em seis capítulos, sendo primeiro a introdução, que aborda a questão a ser analisada pela pesquisa, a delimitação da pesquisa, a definição dos objetivos, a justificativa do tema e a forma como o trabalho está organizado.

O segundo capítulo caracteriza o processo de inovação e apresenta a sua aplicação na cadeia produtiva da indústria da construção, apontando seus principais vetores de influência, além de abordar a importância do Estado como agente de inovação na indústria da construção civil.

O segundo capítulo ainda trata das questões referentes à obra pública, indicando os principais aspectos da legislação pertinente a esse tema e caracterizando os processos de planejamento e tomada de decisão na fase preliminar do processo licitatório. O capítulo também considera a avaliação dos conceitos referentes ao custo e à produtividade dentro do planejamento de obras públicas, além de abordar a questão da qualidade e da sustentabilidade como requisito nas contratações para edificações públicas.

O terceiro capítulo aborda o conceito e o modelo que representa o modo de produção de construção industrializada e que norteia o desenvolvimento da ferramenta de pesquisa, além de uma evolução sobre esse tema, que determinou os parâmetros e entendimentos atuais sobre o processo de industrialização da indústria da construção.

Esse capítulo também trata sobre os principais atributos e demais questões relacionadas aos sistemas construtivos industrializados mais comumente utilizados na construção civil e sobre as particularidades do processo de planejamento dentro do processo de construção industrializada.

No quarto capítulo é apresentada a metodologia utilizada no desenvolvimento do trabalho e a ferramenta de pesquisa utilizada para avaliar os instrumentos dos processos de licitação para contratação de projetos e seus critérios de avaliação. O capítulo também faz uma breve caracterização de ferramentas e métodos de avaliação já existentes que serviram de base para a concepção da ferramenta desenvolvida para a presente pesquisa.

No quinto capítulo são apresentados os estudos de caso, correspondentes a avaliação dos instrumentos de licitação que atendem aos parâmetros impostos pelo 
trabalho a partir da aplicação da ferramenta de pesquisa, e as diretrizes para utilização dos sistemas construtivos industrializados em obras públicas

Nas considerações finais são apresentadas as conclusões e apontadas as sugestões para trabalhos futuros. Destaca-se que os apêndices do trabalho são compostos por tabelas correspondentes às avaliações dos processos licitatórios e por achados de pesquisa. 


\section{INOVAÇÃO NA CPIC E PLANEJAMENTO DE OBRAS PÚBLICAS.}

Este capítulo está dividido em duas partes, dedicadas a abordar dois temas que fundamentam a pesquisa: o conceito de inovação e a sua aplicação na CPIC e o processo de planejamento de obras públicas, ao considerar a importância desse setor para o processo de inovação da CPIC.

A primeira parte tem o objetivo de resgatar conceitos de inovação e caracterizar o processo de inovação na CPIC, identificando a forma adequada aos objetivos da pesquisa. Também aborda o papel que o Estado desempenha como agente de inovação da CPIC.

A segunda parte trata das obras públicas, caracterizando o fluxo e as etapas que compõem esse evento administrativo, sob a ótica da legislação pertinente e da produção acadêmica sobre o tema, com foco no processo de planejamento e de tomada de decisão nas etapas iniciais, a fim de identificar os pontos mais favoráveis ao processo de inovação.

\subsection{Inovação na CPIC}

Schumpeter (1949) entende que a inovação, denominada de "desenvolvimento" por ele, consiste em um processo endógeno, no qual as mudanças econômicas são estabelecidas a partir da própria iniciativa do empreendedor, atribuindo a este um papel fundamental nesse processo. Para Schumpeter, o empreendedor é capaz de induzir as tendências econômicas a partir da criação de novas demandas e do convencimento dos consumidores de que elas são necessárias por meio de um processo de "ensinamento".

Já os economistas Neo-schumpeterianos, tais como Freeman (1994) e Lundval (1992), consideram que o processo de inovação não é endógeno, e está relacionado, principalmente, com a circulação e difusão do conhecimento pela economia, dissociandoo da figura do Empreendedor; sendo que o papel de destaque é atribuído aos Sistemas de Inovação, formados por instituições públicas e privadas que são responsáveis pelo desenvolvimento e difusão de novas tecnologias (MAZZUCATO, 2014).

De modo semelhante, Etzkowitz (2008) considera que a interação entre universidades, indústrias e governo é a chave para a inovação e o crescimento econômico baseado no conhecimento. Essa relação toma a forma de uma hélice formada pelos três agentes, sendo as universidades responsáveis pela Pesquisa e Desenvolvimento de novas soluções; a indústria como o local de produção; e o governo como agente intermediador que garante as interações e trocas de informações. 
Ao considerar as mudanças técnicas como fator chave para o desenvolvimento econômico, Viotti (1997) indica a existência de dois tipos de inovação: as que estão relacionadas com o desenvolvimento de um paradigma tecnológico completamente novo, a inovação de ruptura, e aquelas relacionadas com as mudanças técnicas advindas das oportunidades criadas pelos paradigmas já existentes, a inovação incremental.

Rogers (1971) define inovação como uma ideia, prática ou objeto que é percebido como algo novo para um indivíduo, ou outra unidade - como uma empresa ou instituição, sendo que o processo de desenvolvimento da inovação consiste nas decisões, atividades e seus impactos e é originado pelo reconhecimento de uma necessidade ou problema.

Para Rogers (1971), o processo de inovação é realizado através de seis passos principais: o Reconhecimento do problema ou necessidade, seja através de uma pesquisa seja por meio de uma demanda social ou institucional; a Pesquisa básica e aplicada, referente ao processo de investigação; o Desenvolvimento, que equivale ao processo de colocar uma nova ideia na forma em que ela é capaz de corresponder às necessidades encontradas e avaliadas e de ser adotada como solução; a Comercialização, consiste na produção, venda e distribuição do produto (ou solução) inovador; a Difusão e Adoção, consiste a decisão de disseminar a inovação e assumi-la como solução para a necessidade ou problema identificados; as Consequências, está relacionado à avaliação do sucesso ou fracasso da inovação como solução da necessidade.

Rogers (1971) condiciona a receptividade de uma inovação a cinco atributos que elas devem apresentar: a Vantagem Relativa, que equivale ao benefício financeiro oferecido pela inovação; a Compatibilidade, referente ao quão compatível é a inovação com produtos e práticas existentes; a Complexidade, que se refere ao grau de dificuldade de entendimento e uso; a Verificabilidade (Trailability), está relacionada aos custos de experimentação da inovação - tais como treinamentos e aquisição de equipamentos específicos; e a Observabilidade, que é a facilidade de identificar vantagens relativas para os atores relevantes nos mercados (HEINTZ e WAMELINK, 2015).

Conforme Blumenschein (2004), a inovação em países com industrialização tardia, como o Brasil, tem como principal característica a absorção de conhecimento e o desenvolvimento e disseminação de melhorias. Em outras palavras, há uma tendência de que as inovações nesses países ocorram através da promoção e difusão de mudanças incrementais, com foco no processo de aprendizado contínuo.

A fim de indicar o papel do Estado no processo de inovação, Mazzucato (2014), supera o modelo inicial dos Sistemas de Inovação, propondo que o Estado seja o 
encarregado de comandar o processo de desenvolvimento industrial a partir da criação de estratégias que permitam o avanço tecnológico em áreas prioritárias.

Esse papel vai além da criação do conhecimento desenvolvido por universidades e laboratórios, devendo incluir a mobilização de recursos que permitam a difusão do conhecimento e da inovação pelos diversos setores da economia, chegando ao conceito de Estado Desenvolvimentista, responsável tanto pelo gerenciamento das falhas de mercado quanto pelo comando do processo de industrialização (MAZZUCATO, 2014).

\subsubsection{Processos de inovação na CPIC e seus vetores de influência}

A complexidade, a segmentação e o tradicionalismo do modo de produção da Indústria da Construção (IC) e a singularidade característica do seu produto impõem a essa indústria difíceis barreiras para a sua inovação, seja por meio da implementação de novas soluções e produtos (inovação de ruptura), seja por meio da melhoria de processos existentes (inovação incremental).

Em sua abordagem sobre a inovação por meio da industrialização, Ribeiro (2002) indica que a dificuldade de implementação desse processo está "na própria essência do ato de Construir", destacando a variabilidade e a descentralização da produção, a singularidade do produto e o fato de um novo produto ser sempre executado em local diferente, além do fracionamento do ciclo de produção e do seu caráter temporário.

Toledo et al. (2000) apud ABDI (2009) atribui a pouca difusão das inovações tecnológicas no setor da construção civil às incertezas inerentes a elas, de forma que uma tecnologia só passa a ser adotada por um número razoável de empresas após a sua consolidação no mercado, quando já não são inovações propriamente ditas. Outro obstáculo para adoção de inovações na CPIC é referente a natureza multidisciplinar dos projetos e a dependência do desenvolvimento de novos materiais e equipamentos.

ABDI (2009) também destaca a necessidade de maiores incentivos para que as empresas de construção civil invistam mais em processos de melhoria da qualidade e na inovação, uma vez que esses processos costumam ser dispendiosos e não acessíveis a grande parte das empresas atuantes no mercado nacional, sobretudo as pequenas e médias empresas. Essa dificuldade de investimento é também atribuída às instabilidades econômicas vividas pela IC ao longo de diversos períodos.

Fabrício (2002) aponta que, do ponto de vista da inovação tecnológica na CPIC, há uma limitação de possibilidades de desenvolvimento e pesquisa por parte das construtoras devido ao pequeno porte, de modo geral, das mesmas; o que coloca a cadeia de 
suprimentos como agente central do processo de modernização tecnológica do setor. $\mathrm{O}$ autor ainda destaca que na CPIC, a maioria dos empreendimentos é desenvolvida com base nos padrões tradicionais quanto ao conceito de produto, tecnologia, marketing, entre outros; e não está orientada para a introdução de inovações.

Farah (1992) apud Fabrício (2002), ao reconhecer protagonismo da cadeia de suprimentos no processo de inovação da CPIC, propõe que "as inovações não devem ser vistas como mera imposição dos fabricantes" e defende que são as necessidades da atividade de construção que viabilizam determinada inovação.

Por outro lado, BNDES (2010) destaca a descoordenação da indústria de materiais de construção, caracterizada como extensa e diversa, e o complexo e extenso arcabouço institucional, normas e leis, como desafios a serem superados no curto e médio prazo a fim de que se possibilite o aprimoramento e difusão de processos produtivos inovadores na CPIC.

Para Blumenschein (2004), há um consenso de que as mudanças na Indústria da Construção Civil estão relacionadas com a busca de novas ideias com vistas ao fortalecimento no processo de sobrevivência e desenvolvimento das empresas. A autora ainda destaca a necessidade de identificar como as novas ideias são geradas e integradas ao processo produtivo e ao produto.

No sentido de identificar caminhos para facilitar as mudanças necessárias na CPIC, Blumenschein (2004) identifica quatro vetores de influência para o processo de inovação: Produção, onde a necessidade de produzir leva à busca por inovações incrementais e está relacionada com a curva de aprendizado existente no processo produtivo; Mercado Demanda, relacionado ao foco nos clientes e ao atendimento das suas necessidades específicas, o que leva ao desenvolvimento de novas soluções e de novos produtos; Tecnologia e Pesquisa e Desenvolvimento ( $P \& D)$, diz respeito ao desenvolvimento e introdução de tecnologias aplicadas aos produtos e processos produtivos da CPIC; Empreendedor Lider, referente ao conceito de inovação de Schumpeter, no qual a existência da figura de um empreendedor líder é capaz de induzir à produção de inovações na cadeia produtiva.

CBIC (2008) apud Filha et al. (2010) caracteriza as inovações aplicadas à construção civil de quatro formas: Inovações de produto, relacionada ao objeto (edifício) da construção ou aos seus subsistemas, componentes e materiais; Inovações em processo, referente ao processo de produção, estando relacionada às inovações em produtos intermediários; Inovações organizacionais, que é relacionada à estruturação das empresas 
e à gestão dos processos da cadeia auxiliar; Inovações em Marketing, direcionada ao relacionamento com os clientes, à promoção dos produtos e à comunicação com o mercado.

Outra classificação das diferentes inovações aplicadas à IC, proposta por Filha et al. (2010) a partir da caracterização anterior, considera:

a) "As que agregam características de desempenho aos edificios" - entendidas como inovações relacionadas à melhoria de comportamento em uso da edificação sob a ótica de requisitos de desempenho sem, no entanto, trazer mudanças no processo produtivo.

b) “As que afetam o processo produtivo" - Relacionadas à utilização de materiais, componentes ou subsistemas inovadores ou à forma de fornecimento de insumos que proporcionam inovações de ruptura ou incrementais no processo produtivo, implicando em ganhos de produtividade, qualidade, segurança no trabalho, entre outros.

c) As que afetam os processos internos das empresas - Estão relacionadas à utilização de ferramentas e estratégias gerenciais, tais como a implantação de softwares e arranjos de trabalho com fornecedores.

d) "As que afetam a promoção do produto e sua colocação no mercado" Equivalem às inovações em marketing e estratégias de atendimento às necessidades e de convencimento dos clientes.

Ao comparar a CPIC a um sistema vivo, conforme os conceitos da biologia, Blumenschein (2004) divide a CPIC em cinco partes - organismo, correspondente à CPIC como um todo (a relação entre as diversas cadeias); órgãos, análogos às cadeias de produção, que são compostos por tecidos, equivalentes às subcadeias, que são formadas por diversas células, compatível com as firmas e instituições atuantes e que são tratadas como a unidade básica do processo de inovação, e os genes, que correspondem aos indivíduos (profissionais) que atuam nas empresas e instituições e são responsáveis pela execução das atividades e, analogamente, pelo gene da CPIC, conforme indicado na figura 01 . 


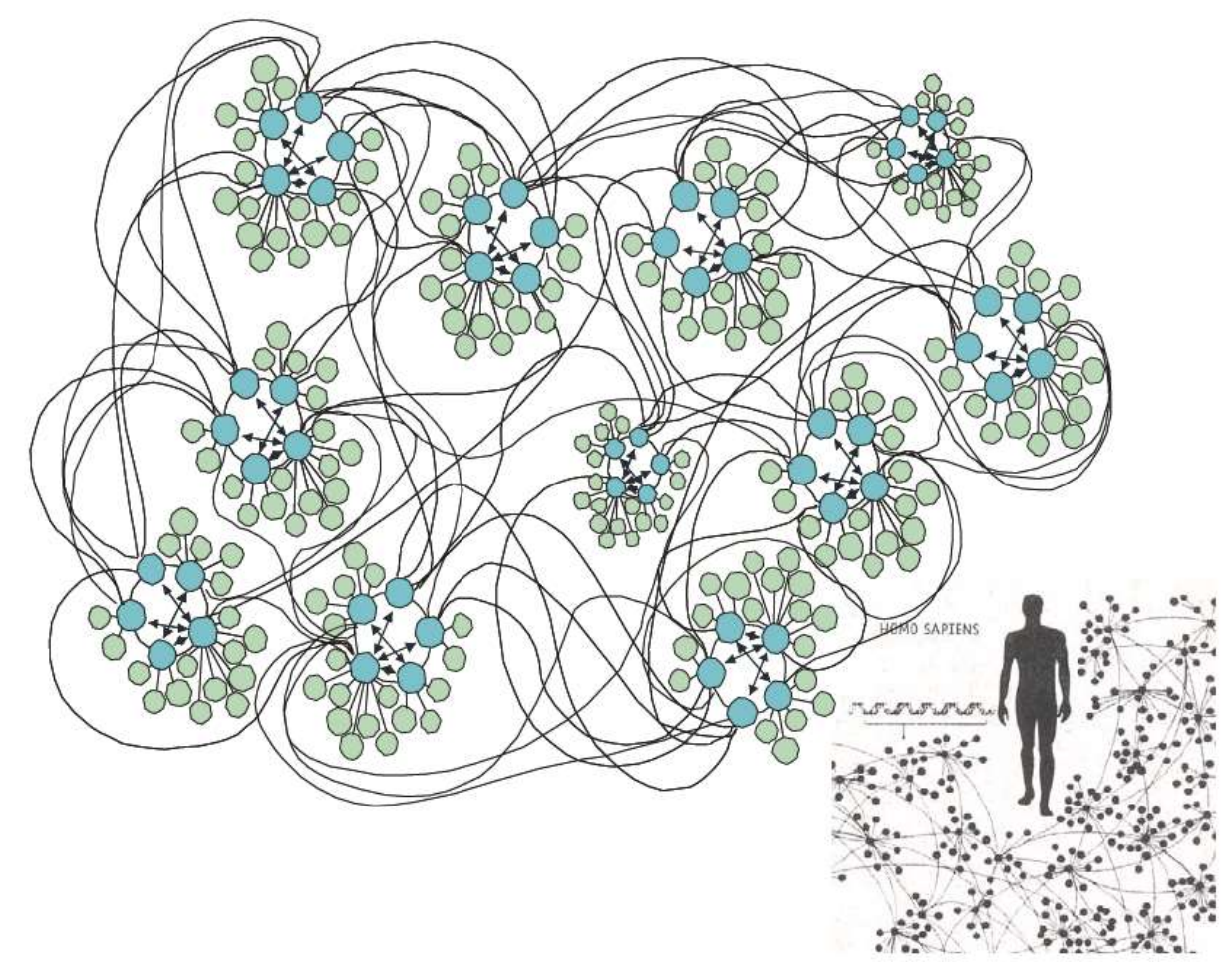

Figura 1. Cadeia produtiva como organismo vivo. Fonte: BLUMENSCHEIN (2004)

Seguindo a alusão da CPIC como um organismo vivo, Blumenschein (2004) compara o processo de inovação da CPIC a um procedimento de engenharia genética, onde a mudança proposta ocorre com a introdução de uma nova informação no código genético das células (as empresas), ou seja, uma indução no comportamento dos agentes que compõem as empresas atuantes nas cadeias da CPIC, que resultará em uma modificação no comportamento de todo o organismo.

Para tanto, Blumenschein (2004) propõe uma metodologia para introdução de inovação da CPIC inspirada na engenharia genética com os seguintes passos: Planejamento, cujo objetivo consiste na definição de metas a serem atingidas; a identificação de recursos necessários - recursos físicos e institucionais; separação de um grupo de células (empresas e instituições) - que tem em vista a formação de uma rede para troca de informações e estímulos; Preparação de um meio apropriado e condições de cultura; indução do Gene e o monitoramento e avaliação. A autora ainda reforça a necessidade de integração das células do setor público, privado e pesquisa.

Blumenschein (2004) ainda observa a capacidade da cadeia principal, representada pelas construtoras, de agir como um catalisador na promoção e disseminação de inovações dentro da cadeia produtiva da construção devido à sua capacidade de determinar comportamentos de agentes das outras cadeias, destacando a relevância de suas células em experiências que necessitem de integração de atores. 
Diante dos vetores de influência citados por Blumenschein (2004), com destaque para a Demanda, e considerando a seleção de células (empresas e instituições) capazes de promover mudanças no organismo (CPIC) como um passo importante para $o$ funcionamento do modelo de inovação citado acima, percebe-se a necessidade de identificar agentes que detenham uma capacidade de demanda suficiente para introduzir uma mudança de comportamento, ou da forma de produzir, da CPIC e assim liderar o processo de inovação.

Em paralelo, ao relacionar os tipos de inovação aplicados à IC, conforme Filha et al. (2010) e o tipo de inovação buscada pelos países de industrialização tardia, ou seja, as inovações incrementais, observa-se também que há uma melhor adequação das "inovações que afetam o processo produtivo" aos objetivos e problemas na IC apontados pela pesquisa, tais como a deficiência em produtividade e qualidade dos processos produtivos e dos produtos.

Por fim, ao reconhecer o modelo de inovação para a CPIC proposto por Blumenschein (2004) como adequado aos objetivos da pesquisa, considera-se que o Estado pode assumir a condição de célula fundamental e indutora do processo de inovação na Indústria da Construção Civil, capaz de acelerar esse processo como um agente catalizador da inovação, graças à sua capacidade de demanda, além do poder normativo e fiscalizador que detém.

\subsubsection{O Estado como agente de inovação}

Ao analisar os papéis dos diferentes agentes econômicos no processo de inovação, Gadelha (2002) trata o Estado como uma instituição decisiva, com capacidade de interferir nas relações de interdependência existente entre as empresas e os mercados e entre estas e as demais organizações que compõem os sistemas nacionais de inovação, dado o poder e a capacidade de arbitragem do Estado. Essa interferência permite a formulação de estratégias convergentes pelos atores envolvidos no processo de inovação.

Quanto à política industrial e de inovação, Gadelha (2002) destaca a necessidade de se construir capacitações dinâmicas dentro do corpo técnico que compõe o Estado a fim de permitir a realização de atividades de prospecção e de interação com o setor privado, viabilizando a concepção de estratégias flexíveis de inovação e de desenvolvimento.

Chang (2004) defende o estímulo ao aprimoramento institucional dos países em desenvolvimento, a possibilidade de desenvolvimento industrial e crescimento 
econômico a partir da combinação de políticas públicas e boas instituições e uma utilização mais ativa de instrumentos de promoção da indústria, a exemplo de tarifas diferenciadas e subsídios.

Ao tratar da indisposição do mercado em assumir os riscos dos investimentos econômicos que o processo de inovação requer, Mazzucato (2014) destaca que o "Estado empreendedor" deve ir além das correções das comuns falhas de mercado, tais como a regulação de monopólios econômicos e redistribuição de recursos e infraestrutura, sendo necessário que ele assuma esses riscos e a criação de uma nova visão de mercado.

Para Mazzucato (2014), “é o Estado agindo como principal investidor e catalisador, que desperta toda a rede para a ação e difusão do conhecimento". A autora ainda expõe que o apoio à inovação por parte do Estado deve ser realizado por meio de investimentos em P\&D, infraestrutura, capacitação profissional e apoio direto e indireto a empresas e tecnologias específicas.

Outro ponto importante no processo de Inovação comandado pelo Estado, conforme Mazzucato (2014), é a maior eficácia atribuída às encomendas de tecnologias que exigem inovação quando comparadas com a distribuição de subsídios ao setor produtivo esperando que a inovação ocorra. Observa-se, portanto, um alinhamento com o vetor de inovação correspondente à Demanda, proposto por Blumenschein (2004).

\subsubsection{Estado como financiador de inovação na CPIC}

Conforme exposto anteriormente, o Estado brasileiro, na última década, pode ser considerado um exemplo de agente indutor do processo econômico, por meio das políticas anticíclicas de combate à crise financeira de 2008. Também é possível observar o reconhecimento da importância da Indústria da Construção no processo de desenvolvimento econômico do país, uma vez que esse setor foi um dos escolhidos como pilar das políticas supracitadas.

A importância do Estado para a IC também é demonstrada por CBIC (2015) ao apresentar a relação entre o ciclo econômico virtuoso vivido pela construção civil no período entre 2007 e 2014 e as políticas públicas de fomento ao setor, seja pela desoneração fiscal para a cadeia de suprimentos, seja pela disponibilidade de financiamento por meio dos bancos públicos de fomento ou ainda por meio de demandas específicas e programas públicos, como o PAC e o MCMV (CBIC, 2015).

Vale lembrar ainda o papel de agente econômico direto que o Estado brasileiro desempenhou nas décadas de 40, 50 e 70, no desenvolvimento da infraestrutura nacional, 
no segundo Governo Vargas e no Governo Juscelino, e na grande oferta habitacional no período militar.

Um exemplo importante é a utilização de sistemas estruturais em aço nas obras dos ministérios federais e do Congresso Nacional em Brasília, a fim de atender uma necessidade de produtividade e cumprimento de prazo, proveniente de uma demanda estatal (BRASIL, 2015).

Mais recentemente, as obras decorrentes dos grandes eventos realizados no país em 2014 e 2016, Copa do Mundo de Futebol e Jogos Olímpicos do Rio de Janeiro, também demandaram soluções inovadoras a fim de cumprir os prazos e as exigências técnicas desses eventos (BRASIL, 2015).

A importância do Estado como um agente indutor de transformações na indústria da Construção também pode ser observada no contexto internacional. Lessing (2006) destaca o programa de habitação do governo Sueco, cujo objetivo era ofertar 100.000 apartamentos por ano durante 10 anos, que desencadeou o primeiro ciclo de busca pela industrialização da construção nesse país.

Outro exemplo da importância do Estado na implementação de soluções inovadoras na IC é apresentado em uma publicação do Escritório de Ciência e Tecnologia do Parlamento Inglês, que destaca a utilização de casas pré-fabricadas no atendimento de uma demanda residencial por parte do governo no contexto do pós-guerra e durante a década de 60 (POST, 2003).

A publicação também apresenta a iniciativa mais recente do governo britânico em desenvolver a utilização de sistemas construtivos industrializados, denominados de Métodos Modernos de Construção (MMC), na construção de novas habitações, a fim de atender ao crescimento da demanda habitacional crescente no início dos anos 2000 (POST, 2003).

Conforme LACIS et al. (2013), o desenvolvimento dos Métodos Modernos de Construção está relacionado com a estratégia do governo britânico de redução do $\mathrm{CO}_{2} \mathrm{e}$ elevar o Reino Unido à liderança mundial em Construção Sustentável. Dentre os instrumentos desenvolvidos para o alcance dos objetivos citados está o Código de Casas Sustentáveis, baseado em padrões desenvolvidos pela British Research Establishment (BRE) - Instituição britânica sem fins lucrativos com atuação no desenvolvimento de práticas, normas e soluções voltadas para sustentabilidade e inovação na CPIC.

Por outro lado, Haw (2009) aponta como uma das barreiras para utilização de sistemas construtivos industrializados no contexto da Malásia a falta de apoio de projetos 
financiados pelo governo local para o setor privado ao mesmo tempo em que aponta o suporte governamental como um dos caminhos para estimular a utilização desses sistemas.

Os exemplos nacionais e internacionais, aliados aos dados referentes à relação existente entre o investimento público e o crescimento da IC, demonstram o papel que as obras ou demandas públicas exercem no seu processo de inovação, além de reafirmarem o papel do Estado como agente catalizador desse processo, indicando a necessidade de analisar o evento obra pública a fim de identificar as oportunidades de inovação da CPIC por meio desse setor.

\subsection{Planejamento de Obras Públicas}

Segundo Silva (2013) a contratação dos serviços para a execução de uma obra pública é um cenário em que são evidenciadas as influências das compras públicas, devido a algumas características peculiares inerentes a esse processo, tais como o volume das obras contratadas anualmente, o impacto que elas causam no meio ambiente e o volume de recursos movimentados por elas.

Conforme o TCU (2013), Obra Pública é "toda construção, reforma, fabricação, recuperação ou ampliação de bem público"; podendo ela ser realizada de maneira direta, quando executada pelo próprio órgão ou entidade da administração, por seus próprios meios, ou de forma indireta, quando a execução é contratada com terceiro através de processo licitatório TCU (2013).

Diante da segunda possibilidade, a mais comum, a legislação brasileira determina que os serviços técnicos envolvidos, tais como projetos, a execução da obra e as demais aquisições pertinentes para a materialização do empreendimento devem ser contratadas por meio do processo de Licitação.

Destaca-se ainda que, diante da contratação indireta de serviços vinculados à realização de uma obra pública, é de responsabilidade da instituição contratante o fornecimento de subsídios técnicos, a avaliação, o gerenciamento e fiscalização das obras e a conferência de resultados e contratos (OLIVEIRA, 2013).

Outro ponto a ser observado é que essas obrigações também ficam a cargo da entidade contratante quando a elaboração dos projetos técnicos das diversas especialidades necessárias à obra é executada por uma empresa contratada, externa ao corpo técnico do ente público. 


\subsubsection{O fluxo da Obra Pública}

Segundo o TCU (2013), a materialização da obra pública é um evento administrativo dependente de várias fases, iniciadas bem antes do processo licitatório ainda na definição do objeto a ser contratado - e que vão além do termo de entrega, abrangendo as fases de operação da edificação e de manutenção da mesma.

O evento Obra pública pode ser estruturado em quatro fases: a fase preliminar (na qual ocorre definição do objeto a ser contratado), fase interna e fase externa de licitação (correspondentes ao processo licitatório propriamente dito, sendo que na fase interna são desenvolvidos os projetos do objeto a ser licitado, enquanto que na fase externa ocorre o processo de contratação da obra pública), a fase contratual (em que as obras são de fato executadas e entregues) e a fase posterior à contratação (correspondente à operação e manutenção do objeto construído), conforme indicado na figura 02 .

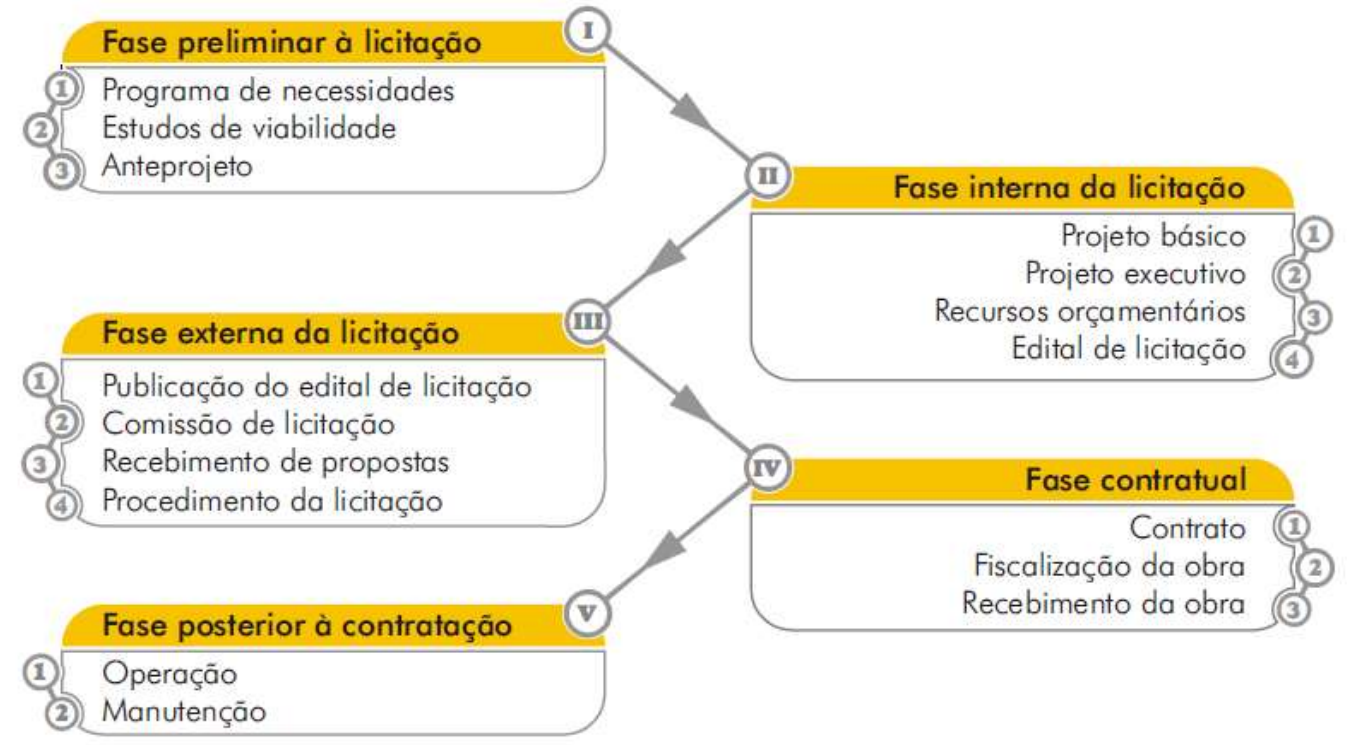

Figura 2. Fases da Obra Pública. Fonte: TCU (2013).

A partir do fluxograma apresentado, observa-se que, embora seja necessário um planejamento integrado que contemple todas as fases e suas respectivas atividades, é na fase preliminar à licitação (Fase I) que o objeto é concebido e os requisitos técnicos a serem atendidos pela edificação são definidos. As etapas incluídas na fase preliminar têm o objetivo de identificar necessidades, estimar recursos e escolher a melhor alternativa para o atendimento dos anseios da sociedade local (TCU, 2013).

Outro aspecto importante do fluxo padrão da obra pública é a fragmentação do processo. Melhado e Oliveira (2002) atentam para a falta de comunicação entre projeto e obra nos empreendimentos públicos ao indicar que, devido ao fato de a contratação da 
obra só ocorrer após a finalização dos projetos - com exceção da contratação conjunta do projeto executivo com a obra, não há participação do responsável pela construção na etapa inicial de idealização e concepção genérica do produto.

Da mesma forma, os autores atentam para ausência de acompanhamento da obra por parte dos projetistas, atribuindo ao próprio sistema contratação dos serviços de projetos a indução de uma ruptura entre a equipe de projeto e os responsáveis pela execução da obra, sendo essa situação reconhecida como um dos pontos críticos para a garantia de qualidade dos empreendimentos públicos (MELHADO e OLIVEIRA, 2002).

\subsubsection{Legislação Pertinente}

Em atendimento ao princípio da legalidade na administração pública, que, segundo Alexandrino (2012), estabelece que a atuação do estado deve ser pautada na lei, não podendo agir contra ou além da determinação legal, o processo de compras e alienações, bem como a contratação de obras e serviços devem ser realizados por meio do processo de licitação, salvo disposição legal que determine o contrário (BRASIL, 1988).

Alexandrino (2012) trata a licitação como "procedimento administrativo, de observância obrigatória pelas entidades governamentais, em que, observada a igualdade entre os participantes, deve ser selecionada a melhor proposta dentre as apresentadas pelos interessados em com elas travar determinadas relações de conteúdo patrimonial, uma vez preenchidos os requisitos mínimos necessários ao bom cumprimento das obrigações a que eles se propõem”.

Em Brasil (2013) consta que “o objetivo de licitar é garantir a observância do princípio constitucional da isonomia e selecionar a proposta mais vantajosa para a Administração", apresentando, portanto, mais um princípio da licitação, a isonomia.

O estabelecimento da licitação como regra jurídica pode ser encontrado em diversos estatutos, sendo o mais importante deles a própria Constituição Federal de 1988, que, em seu Art. 37, XXI, institui a obrigatoriedade do processo licitatório. A constituição ainda determina a edição de leis específicas para abordar o assunto, sendo a lei federal 8.666/1993, o estatuto geral das licitações, a principal.

\subsubsection{Lei 8.666/1993 - Lei Geral das Licitações}

A lei 8.666/1993, também chamada de lei geral da licitação, aponta os princípios norteadores do processo licitatório, as fases, as modalidades, os regimes de contratação, os tipos (que correspondem aos critérios de avaliação), os instrumentos administrativos que determinam o processo (tais como editais, termos de referências e minutas de 
contrato), os casos específicos de dispensa e inexigibilidade, as obrigações e direitos das partes envolvidas e outras determinações que garantam a efetividade do processo.

Quanto aos casos de contratação de obras e projetos, observa-se que Lei 8.666/93 traz conceitos e definições importantes para a viabilização do processo licitatório, tais como as definições de projeto básico (conjunto de elementos necessários e suficientes para caracterizar a obra ou serviço) e projeto executivo (conjunto de elementos necessários e suficientes para a execução da obra).

A Lei 8.666/93 traz determinações quanto ao andamento do processo e obrigações a serem seguidas, a exemplo da previsão de recursos e existência de projeto executivo ou projeto básico aprovado pela entidade responsável como condição para o seguimento da licitação de obras.

Porém a lei não apresenta a mesma precisão no que diz respeito às atividades da fase preliminar, ou fase interna, onde é realizada a concepção do objeto licitado, não apresentando o necessário detalhamento quanto aos estudos de viabilidade e as etapas iniciais de projeto.

Dessa forma, a lei 8666 restringe-se em orientar como produzir um projeto básico, estabelecendo os elementos que deverão integrá-lo - tais como o desenvolvimento da solução escolhida e seu suficiente detalhamento, a identificação dos serviços e insumos necessários e orçamento detalhado.

\subsubsection{Lei 10.520/2002 - Institui a Modalidade Pregão.}

Enquanto a Lei 8.666/93 apresenta as cinco modalidades iniciais de licitação convite, tomada de preços, concorrência, concurso e leilão - e as possibilidades de dispensa e inexigibilidade de licitação - a Lei 10.520/2002 introduz na administração pública a modalidade pregão, definida por Alexandrino (2012) como "modalidade de licitação, sempre do tipo menor preço destinada à aquisição de bens e serviços comuns, que pode ser utilizada para qualquer valor de contrato".

A partir dessa definição, depreendem-se pontos importantes da modalidade pregão que a diferencia das demais modalidades, instituídas pela lei 8.666/93; entre eles citamse: a utilização do pregão para qualquer valor, já que as outras modalidades possuem restrições ou observações quanto aos valores para sua utilização; a sua restrição quanto ao tipo de licitação (ou critério de avaliação das propostas) permitindo apenas o tipo "menor preço", enquanto que as demais modalidades também utilizam a "melhor técnica" e a "técnica e preço"; e a sua aplicação restrita à aquisição de bens e serviços comuns. 
Quanto ao último ponto, a lei $10.520 \mathrm{em}$ seu Art. $1^{\circ}, \S 1^{\circ}$, define bens e serviços comuns como "aqueles cujos padrões de desempenho e qualidade possam ser objetivamente definidos pelo edital, por meio de especificações usuais no mercado". Essa definição, a princípio, exclui a elaboração de projetos técnicos como objeto da modalidade pregão, porém essa é uma questão polêmica já que envolve a definição do que seria serviço comum de engenharia e a possibilidade do enquadramento da atividade projetual nessa definição.

A súmula 257/2010 do Tribunal de Contas da União (TCU) determina que "o uso do pregão nas contratações de serviços comuns de engenharia encontra amparo na Lei $\mathrm{n}^{\circ}$ 10.520/2002”, porém decisões dessa corte de contas, a exemplo do processo TC 033.958/2010-6, tratam a modalidade Pregão como inadequada para a contratação de projetos técnicos de engenharia e arquitetura devido à especificidade dessas atividades.

Ainda sobre a modalidade Pregão, outra inovação que a lei 10.520/2002 trouxe foi a instituição da inversão das fases de habilitação e julgamento das propostas no processo licitatório a fim de garantir maior celeridade à licitação. Dessa forma, primeiro julga-se a melhor proposta e posteriormente confere-se a habilitação do candidato vencedor, que ao estar devidamente habilitado será considerado o vencedor do certame. Caso contrário, segue o processo com a verificação da habilitação do segundo colocado, e assim por diante, até que algum candidato satisfaça as exigências da habilitação.

\subsubsection{Lei 12.462/2011 - Institui o Regime Diferenciado de Contratações}

Com o objetivo inicial de garantir a celeridade e os prazos das obras para os grandes eventos sediados no país nessa década, Copa do Mundo de Futebol FIFA 2014 e Jogos Olímpicos do Rio de Janeiro 2016, foi instituído no ordenamento jurídico brasileiro, pela Lei 12.462/2011, o Regime Diferenciado de Contratações (RDC).

Segundo Andrade (2012), o RDC “constitui disciplina excepcional e transitória, facultativamente aplicável às licitações e aos contratos no âmbito da administração pública brasileira". Ainda segundo o autor, "a lei n 12.462 parece ter instituído uma nova modalidade de licitação, combinando alguns elementos das modalidades até então existentes na disciplina administrativa”.

De fato, os regimes de contratação presentes na lei 8.666/93 (empreitadas por preço unitário, global e integral e contratação por tarefa) foram mantidos no RDC, que por sua vez instituiu o regime de contratação integrada, onde a elaboração dos projetos básico e executivo fica a cargo da contratada para a execução da obra. 
Para a utilização do regime de contratação integrada, a lei 12.462 impõe como condição a inovação tecnológica ou técnica e a possibilidade de execução com diferentes metodologias. A lei ainda determina a existência de um anteprojeto de engenharia que caracterize objeto da obra no instrumento convocatório da licitação, o que implica na concepção prévia do objeto pela entidade contratante por meio próprio ou por meio da contratação de empresa especializada, o que resulta em outro processo licitatório, exclusivo para a contratação do anteprojeto.

A lei também traz a possibilidade de inversão das fases de habilitação e julgamento de propostas, instituída pela lei 10.520, e também apresenta a novidade da forma de pagamento dos serviços de execução das obras por meio da remuneração variável vinculada ao desempenho da contratada.

2.2.2.4 Lei 13.303/2016 - Lei das Estatais

A Lei 13.303/2016, conhecida como lei das Estatais, tem como objetivo a regulamentação das empresas públicas e sociedades de economia mista nas três esferas da república, União, estados e municípios (PIOVESAN e CRISTÓVAM, 2017).

O surgimento dessa lei é parte do processo de reforma administrativa proposta pelo governo federal no final da década de 1990 e atende ao artigo 173 da Constituição Federal, que trata da exploração direta de atividade econômica pelo Estado através das empresas que ele possui, as Empresas Públicas, ou da participação na condição majoritária, as Sociedades de Economia Mista (PIOVESAN e CRISTÓVAM, 2017).

Entre as principais inovações da Lei quanto aos processos licitatórios e de contratação, estão a redução dos limites para dispensa de Licitação para obras e serviços de engenharia (até $R \$ 100.000,00$, contra os $R \$ 150.000,00$ da lei 8.666/93) e para serviços e demais compras (até $\mathrm{R} \$ 50.000,00$, contra os $\mathrm{R} \$ 80.000,00$ da lei 8.666/93).

A Lei 13.303 também instituiu o regime de contratação semi-integrada (que envolve a elaboração e o desenvolvimento do projeto executivo, sem incluir o projeto básico, junto com a execução da obra e demais serviços suficientes para a entrega do serviço) (BRASIL, 2016).

Outro ponto de destaque é a importância dada à etapa de anteprojeto ao determinar os elementos mínimos que este deve conter, incluindo: a demonstração e justificativa do programa de necessidades, da visão global dos investimentos e definições relacionadas ao nível de serviço desejado; as condições de solidez, segurança e durabilidade e prazo de entrega; a estética do projeto arquitetônico; os parâmetros de adequação ao interesse 
público, à economia na utilização, à facilidade na execução, aos impactos ambientais e à acessibilidade; entre outros.

Vale destacar que essa melhor definição dos elementos do anteprojeto pode ser considerada um importante avanço na lacuna existente na Lei 8.666/93 quanto às atividades da fase anterior da licitação, uma vez que esses elementos podem ser trabalhados de forma a estabelecer critérios e diretrizes para o projeto e planejamento do empreendimento de maneira mais objetiva e precisa.

No entanto, a Lei 13.303/2016 também dispensa maior atenção às fases vinculadas à execução da obra e não faz uma abordagem precisa quanto a contratação dos serviços de projeto e planejamento quando há a necessidade de que a prestação desses sejam realizadas por terceiros.

A lei ainda faz referência a questões já implementadas pela lei do RDC, a exemplo da possiblidade de instituir a remuneração variável conforme a produtividade e rendimento da contratada, porém ainda não demonstra a capacidade de resolver os problemas referentes à falta de interação existente entre projeto e obra devido a manutenção da segmentação entre essas etapas.

Diante do exposto, nota-se que a contratação de projetos técnicos, sobretudo os arquitetônicos que tenham em seu escopo a concepção do objeto, ainda é melhor definida pelas Leis 8.666/93 e 13.303/2016, já que elas tratam da possibilidade de contratação do serviço de projeto envolvendo todas as etapas e apresentam os critérios de avaliação "melhor técnica" e "técnica e preço", mais condizentes com a natureza desses serviços.

A presente pesquisa considera a Lei 8.666/93 mais adequada aos seus objetivos por possuir uma abrangência maior e um número maior de modalidades adequadas à contratação de projetos, já que é a única que apresenta a modalidade Concurso, além de ter sido a base para elaboração das outras leis.

\subsubsection{Contratação de Serviços Técnicos (Projeto e Planejamento)}

A forma mais comum da contratação de projetos e obras é por meio de processos licitatórios distintos para cada objeto. Quanto à contratação de projetos que envolvam a concepção da edificação pública, a lei 8.666/93 estabelece a possibilidade por meio das modalidades Convite, Tomada de Preços, Concorrência e Concurso, sendo que as duas primeiras possuem restrição quanto ao valor da contratação (R\$ 150.000,00 e R\$ 1.500.000,00, respectivamente), ao contrário das duas últimas, aplicáveis a qualquer valor. 
A modalidade Concurso, conforme a letra da lei, é a modalidade mais indicada para a seleção de trabalho técnico, científico ou artístico, uma vez que o foco da avaliação no processo licitatório está na qualidade do objeto proposto (BRASIL, 1993). Por outro lado, as outras três modalidades possuem foco da avaliação na empresa postulante ao contrato, nos tipos de licitação "melhor técnica", ou simplesmente no valor proposto para a prestação dos serviços, no caso de licitação do tipo "menor preço", havendo ainda a possibilidade de combinação dos dois critérios, licitações do tipo "técnica e preço".

Ely (2016) aponta uma série de dificuldades comumente encontradas no processo licitatório e que acabam funcionando como barreiras para o sucesso do mesmo, classificando-os quanto às seguintes questões: Questões legais, a exemplo da falta de clareza e complexidade da legislação e da falta de conhecimento da mesma pelo corpo técnico e pelos postulantes ao contrato; Questão de Gestão, com destaque para a falta de comunicação entre os setores envolvidos na licitação e entre as etapas de projeto e obra e a ingerência política; Questão de fiscalização, tais como parcialidade da fiscalização e carência de quadro técnico; Questão de escolha do licitante, uma vez que há uma preferência pela adoção do critério do menor preço, além da insuficiência de requisitos técnicos para a seleção do contratante; Questões de custo e preço, a escolha pelo critério do menor preço tende a resultados de escolha em que a proposta vencedora fique abaixo do valor da obra acarretando na baixa qualidade dos serviços contratados; Questão de documentação, referente às lacunas e divergências existentes nos instrumentos (documentos) que compõem o processo licitatório; e Questões de tempo, que trata da inadequação dos prazos para elaboração da parte técnica do processo licitatório, resultando em vários dos problemas anteriores e em atividades que não agregam valor.

A viabilidade do processo licitatório e a garantia da melhor escolha do objeto licitado estão diretamente vinculadas à qualidade dos instrumentos licitatórios, que são os documentos que garantem o princípio da formalidade ao processo e exteriorizam as necessidades da administração e as regras e requisitos impostos pela mesma aos interessados em participar do certame. Em relação a contratação de projetos, destacamse os instrumentos Edital ou Carta-convite, Termo de Referência e Projeto Básico.

A lei 8.666/93 apresenta em seu artigo $3^{\circ}$ os princípios que regem o processo licitatório; e entre eles encontra-se o princípio da vinculação ao instrumento convocatório, representado pelo Edital ou Carta-convite - no caso da modalidade Carta Convite, que consiste na obrigatoriedade da observância das normas e condições instituídas pelo ato convocatório tanto pela Administração quanto pelo licitante. 
Dessa forma, o Edital é o documento oficial elaborado pelo ente público contratante que estabelece as regras impostas aos participantes do processo licitatório, licitantes e a própria contratante, e formaliza o andamento do processo, indicando a modalidade, descrevendo o objeto, estabelecendo os prazos para as diversas etapas e procedimentos do processo e os critérios de avaliação envolvidos, entre outras determinações.

Para Nahmias et al. (2013), "o Termo de Referência é o instrumento elaborado pela Administração para explicitar o conjunto de informações necessárias à aquisição/contratação que almeja realizar”. Dessa forma, entende-se que o Termo de Referência é um instrumento acessório cuja finalidade é caracterizar o objeto a ser adquirido ou contratado, e, no caso da contratação de projetos técnicos, determinar as diretrizes para as atividades de projetação e para o desempenho do objeto projetado.

Conforme disposto na Lei 8.666/93, o projeto básico consiste em um “conjunto de elementos necessários e suficientes, com nível de precisão adequado, para caracterizar a obra ou serviço, ou complexo de obras ou serviços objeto da licitação, elaborado com base nas indicações dos estudos técnicos preliminares". Para Nhamias et al. (2013) o projeto básico é "um instrumento que permite à Administração saber o que comprar/contratar, quando, estimar o custo, a viabilidade e disponibilidade do mercado em fornecer".

Compreende-se, portanto, que o projeto básico, tal como descrito pela lei 8.666/93, corresponde à descrição do objeto com as devidas diretrizes e especificações, podendo ser constituído por projetos gráficos ou simplesmente por documentos que cumpram a função de explicitar o real desejo da administração e suas necessidades.

\subsubsection{Processo de Planejamento e tomadas de decisão}

Conforme citado anteriormente, há uma segmentação entre as etapas que compõem o fluxo de uma obra pública, havendo uma fragmentação entre as atividades de projeto e planejamento preliminar e as de execução e montagem da obra, sendo esta atribuída, sobretudo às exigências das leis que tratam do assunto.

A lei federal 8.666/93, em seu Art. $7^{\circ}, \S 2^{\circ}$, estabelece que as obras e serviços somente poderão ser licitados quando houver projeto básico aprovado pela autoridade competente, o que implica na elaboração do projeto da edificação sem a participação ou consulta de quem vai executá-la.

A mesma lei, em seu Art.9, I e II, veda a participação do autor ou empresa responsável pela elaboração do projeto básico ou executivo na licitação da obra, 
permitindo sua participação somente na condição de consultor ou técnico, nas funções de fiscalização, supervisão ou gerenciamento, exclusivamente a serviço da administração pública. Há, porém, a possibilidade de a contratação da obra envolver a contratação do projeto executivo como encargo do contratado, o que não contempla a fase de concepção do empreendimento.

Dentro da mesma problemática, a lei 12.462/2011, que introduz o Regime diferenciado de Contratação - RDC, traz em Art. $9^{\circ}, \S 1^{\circ}$ o conceito da contratação integrada, definido como a "elaboração e o desenvolvimento dos projetos básico e executivo, a execução de obras e serviços de engenharia, a montagem, a realização de testes, a pré-operação e todas as demais operações necessárias e suficientes para entrega final do objeto". Porém a mesma lei estabelece a existência prévia do anteprojeto de engenharia, que concebe o objeto e define seus requisitos e sua estética, o que acaba por manter a situação de fragmentação entre concepção e execução, assim como na lei 8.666/93.

Para Fabrício (2002), as decisões relativas à montagem estratégica de um empreendimento público são tomadas pela entidade contratante e por equipes internas de projeto, sendo, muitas vezes, influenciadas por pressões e critérios políticos, e ainda caracterizadas pela definição do programa funcional de forma pouco sistemática.

Já Castro (2013) aponta como característica marcante do processo de planejamento de obras públicas a situação majoritária da falta de quadro técnico suficiente para atender às demandas de projeto e planejamento, sendo bastante frequente a contratação dos projetos técnicos por meio de processo licitatório próprio, anterior à licitação das obras.

Porém, vale destacar que mesmo quando a concepção estética da edificação fica a cargo de um terceiro, cabe à entidade pública definir as diretrizes e os requisitos a serem atendidos pelo objeto contratado, sendo que essas determinações devem estar devidamente dispostas nos instrumentos que compõem o processo licitatório.

Conforme Castro (2013), é responsabilidade da instituição contratante, o fornecimento de subsídios técnicos, avaliação, gerenciamento, coordenação e fisscalização dos serviços, conferência de resultados e contratados relativos à prestação de serviços técnicos e obras por terceiros.

Segundo Andrade (2002), a Lei Complementar $N^{\circ} 101$ de 2000, que trata da Responsabilidade fiscal, introduziu a obrigação de sempre buscar a eficiência e evitar o desperdício com o bem público aos administradores públicos, sendo que o planejamento é uma ferramenta capaz de reduzir os custos decorrentes de falhas. 
A autora também destaca que, apesar da importância atribuída ao planejamento, as práticas de construção pública permanecem assentadas na projetação baseada em fases estanques que utiliza uma variedade de formas de representação bidimensionais isoladas em cada fase de projeto, com diferentes níveis de detalhamento e constituem produtos diferentes. Esse processo fragmentado acarreta na existência de imprecisões e inconsistências que, em muitos casos, são identificadas apenas tardiamente, indicando a necessidade de questionamento da forma tradicional de projeto (ANDRADE, 2002).

A falta de conformidade entre os instrumentos regulatórios e seus conceitos relacionados à obra pública, necessária para a obtenção de uma uniformização de procedimentos adequada e das exigências a serem cumpridas pelos processos licitatórios, e a falta de aplicação integrada e consistente entre as leis, normas e regulamentos vigentes, são apontadas como entraves à qualidade da obra pública que carecem de solução (ANDRADE, 2002).

Sobreira et al. (2007) considera que o fato de importantes determinações técnicas e financeiras da Lei de licitações não serem observadas em processos de contratação pode estar atrelado ao caráter genérico de como elas estão estabelecidas no texto normativo, bem como pela falta de critério na ponderação de prioridade dos requisitos a serem atendidos.

Ely (2016) atenta para a necessidade de um olhar mais detalhado quanto às atividades do processo de gestão dos projetos, aos atores envolvidos, ao tempo de realização das atividades e aos recursos necessários para sua execução, a fim de que se tenha um conhecimento sobre o desenvolvimento do produto, serviço de engenharia ou obras públicas.

Segundo Camarão; Daniel (2016), “é na fase interna, no momento da definição do objeto que subsidiará o Edital de Licitação, que se cometem equívocos insanáveis que acabam por macular todo o procedimento", o que evidencia a importância que deve ser atribuída a essa etapa.

Conforme Brasil (2014), o estudo de viabilidade deve ser constituído por estudo e desenho que assegurem a viabilidade técnica e o adequado tratamento do impacto ambiental e por relatório que contenha a descrição e avaliação da alternativa selecionada, suas características principais, critérios, índices, parâmetros, demandas a serem atendidas e pré-dimensionamento dos elementos da obra.

Diante do exposto, observa-se que as duas primeiras fases do processo de licitação, fase preliminar e fase interna, concentram as atividades de planejamento que terão maior 
influência no andamento das fases seguintes e no resultado da obra, com destaque para a fase preliminar - onde o objeto é concebido e seus aspectos e requisitos são determinados e as soluções quanto aos sistemas construtivos e métodos de execução começam a ser tomadas.

Destaca-se ainda que a segmentação entre as fases de projeto e de execução exige maior atenção e precisão nas decisões tomadas durante as fases que possuem influência direta na execução e no desempenho do objeto a ser edificado, sendo necessária a elaboração do programa de necessidades e do estudo de viabilidade com o máximo de atenção e a devida avaliação dos aspectos e requisitos que a obra deverá atender.

\subsubsection{Avaliação de Custo e produtividade}

Brasil (2014) aponta que "a Lei 8.666/93 dispõe que as obras e serviços de engenharia só poderão ser licitados quando houver previsão de recursos orçamentários que assegurem o pagamento das obrigações a serem executadas no exercício financeiro em curso, de acordo com o respectivo cronograma" e que a Lei de Responsabilidade Fiscal (Lei Complementar $n^{\circ} 101 / 2000$ ) recrimina a geração de despesa ou assunção de obrigação que não observe seus dispositivos, tais como a necessidade de existência de dotação suficiente na lei orçamentária anual, considerando tais práticas como não autorizadas, irregulares e lesivas ao Patrimônio Público.

Essa relação entre previsão de despesas decorrentes da obra pública e o orçamento da administração pública também pode ser relacionada com o princípio do orçamento das lições de Administração Financeira e Orçamentária denominado "Princípio da Anualidade ou da Periodicidade", que, segundo Paludo (2013), consiste no fato de que a estimativa de receitas e as autorizações de despesas devem ser referentes a um período limitado de tempo, geralmente o ano civil.

Conforme Brasil (2014), essas disposições têm por objetivo evitar a paralisação futura da obra pública por deficiência de recursos orçamentários e financeiros. Sendo de grande importância que a elaboração adequada da estimativa de custo da obra, que por sua vez possui relação direta com a qualidade dos projetos.

A partir dos estudos realizados e da legislação pertinente às obras públicas, observase que o fator Custo geralmente é considerado em um momento posterior à concepção inicial, durante as etapas de orçamentação (orçamento preliminar e orçamento detalhado), sendo ele entendido como um somatório dos Custos Diretos e Custos Indiretos. 
Segundo Brasil (2013), os Custos Diretos correspondem à soma do produto "quantitativo multiplicado pelo custo unitário" dos serviços necessários à execução do empreendimento e são referentes basicamente aos insumos (mão-de-obra, equipamentos, materiais e componentes) envolvidos em cada tarefa ou etapa da obra.

Já os Custos Indiretos correspondem aos valores que, embora não estejam vinculados à produção de valor agregado ao empreendimento e aos insumos, são necessários para o andamento da obra, tais como despesas administrativas e manutenção do canteiro de obras.

Observa-se também que a prática referente à avaliação dos custos geralmente está restrita às etapas de projeto e execução, não considerando todo o custo do ciclo de vida do empreendimento. No entanto, há um apelo normativo para que se considerem os custos operacionais da obra, a exemplo da Lei 8.666/93, art.12, III e V, que aponta entre os requisitos a serem considerados nos projetos básico e executivo a economia e a facilidade na execução, conservação e operação do empreendimento.

Outro fator que deve ser considerado no planejamento das Obras públicas é a Produtividade, que segundo a Instrução Normativa do Ministério do Planejamento e Gestão (MPOG) IN n05/2017 consiste na "capacidade de realização de determinado volume de tarefas em função de uma determinada rotina de execução de serviços, considerando-se os recursos humanos, materiais e tecnológicos disponibilizados, o nível de qualidade exigido e as condições do local de prestação do serviço" (BRASIL, 2017).

Matos (2006) define a produtividade como "taxa de produção de uma pessoa ou equipe ou equipamento", ou "quantidade de unidades de trabalho produzidas em um intervalo de tempo específico", sendo o mais comum a hora. Para o autor, a produtividade afeta diretamente a composição de custo do orçamento da obra. Isso se deve ao fato de os custos unitários das tarefas, principalmente quanto a mão de obra, serem calculados tomando por base os índices de produtividade.

Conforme Berezowsk (2011), as composições de preços dos serviços da forma como são elaboradas atualmente não incorporam, em muitos casos, os ganhos de produtividade das equipes resultantes da adoção das modernas técnicas construtivas e da utilização de mão de obra terceirizada para a realização dos serviços. $\mathrm{O}$ autor também destaca a influência que as mudanças das condições inerentes à execução dos serviços exercem sobre produtividade, tais como as características da edificação.

Além da relação com a composição dos custos unitários das diversas tarefas que compõem a obra, a produtividade também deve ser relacionada com as perdas geradas 
nessas atividades, que segundo Formoso (1996) devem englobar além das perdas de materiais, incluindo assim qualquer dispêndio de recurso que não seja convertido em agregação de valor.

Conforme a publicação que apresenta os conceitos e a metodologia utilizada no SINAPI - Sistema Nacional de Pesquisa de Custos e Índices da Construção Civil, a orçamentação de uma obra deve contemplar tanto os tempos produtivos, que agregam valor ao empreendimento, quanto os tempos improdutivos - que mesmo sem agregar valor ao empreendimento são necessários à sua materialização - a fim de retratar a realidades das obras com maior fidelidade (CAIXA, 2017).

A aferição dos tempos improdutivos tem por objetivo tornar claro os pontos de ociosidade de insumos e de improdutividade ou produtividade insatisfatória, que podem ter consequências no valor final do empreendimento, e que auxiliam no processo de tomada de decisão ao indicar os possíveis gargalos de produtividade. Ao relacionar a questão da produtividade com as imposições legais quanto a gestão orçamentária e administrativa, se torna importante observar a necessidade de planejar o empreendimento com vistas a garantir índices de produtividade suficientes para cumprir os prazos vinculados à destinação dos recursos orçamentários para o empreendimento.

Esse planejamento se faz necessário para mitigar possíveis problemas para a execução do empreendimento, tais como a transferência de obrigações financeiras de uma gestão pública para outra e a possiblidade de descontinuidade de políticas públicas e das obras iniciadas em gestões anteriores.

\subsubsection{Sustentabilidade como requisito de planejamento de edificações públicas.}

Quanto à questão da sustentabilidade nas aquisições públicas, observa-se que o arcabouço legal determina o compromisso que a administração pública deve ter com esse tema; a exemplo da lei 8.666/93, que estabelece a promoção do desenvolvimento nacional sustentável como uma das finalidades do processo licitatório. Outro exemplo é a lei 12.462/2011, referente ao $\mathrm{RDC}$, que aponta o objetivo de incentivar a inovação tecnológica através do processo licitatório (BRASIL, 2014).

Já a Instrução Normativa ${ }^{\circ} 05$ do MPOG determina que o processo de contratações de serviços sob o regime de execução indireta deverá observar os critérios e práticas de sustentabilidade como requisito de contratação. A IN n ${ }^{\circ} 01$ - que trata de forma específica da sustentabilidade nas obras da Administração Pública Direta, autárquica e fundacional

- determina algumas práticas sustentáveis com vistas à redução do impacto ambiental da 
obra, seja por meio da redução do consumo de energia e de recursos naturais, seja por meio da utilização de tecnologias e materiais de menor impacto.

Algumas políticas públicas foram importantes para o desenvolvimento do tema da sustentabilidade na Administração pública, a exemplo da instituição do Programa Brasileiro de Qualidade e Produtividade no Habitat (PBQP-H) - que tem o objetivo de desenvolver a construção civil quanto à produtividade, qualidade e introdução de soluções tecnológicas inovadoras - dos sistemas de avaliação que o compõem, a exemplo do Sistema Nacional de Avaliação Técnica (SINAT) e Sistema de Avaliação da Conformidade de Empresas de Serviços e Obras da Construção Civil (SiAC).

Outro exemplo de política pública quanto à sustentabilidade na CPIC é a instituição de processos de certificação, tais como o Programa Nacional de Eficiência energética em Edificações (PROCEL - EDIFICA), voltado para a gestão de recursos naturais nas edificações. Cita-se ainda o Selo Casa Azul, que consiste em uma classificação socioambiental voltada para projetos habitacionais, também com foco na gestão de recursos naturais (CAIXA, 2017).

Observa-se, portanto, um movimento da administração pública quanto a busca de introduzir questões relacionadas à sustentabilidade no âmbito das contratações de obras de interesse público. Embora haja dentro do arcabouço legal orientações gerais para a elaboração dos instrumentos licitatórios para contratação de serviços técnicos de engenharia e obras, os requisitos relativos à sustentabilidade ainda não estão plenamente desenvolvidos nesses documentos.

\subsection{Síntese analítica do capítulo}

Ao abordar o conceito de inovação aplicado à CPIC, o capítulo expõe a importância da inovação para o desenvolvimento econômico e a diferenciação entre as inovações de ruptura, que consistem em um novo paradigma de produção, e as inovações incrementais, relacionadas à melhoria de processos existentes. Importante destacar a tendência de inovações incrementais nos países de industrialização tardia, como o Brasil, conforme exposto por Blumenschein (2004).

A primeira parte do capítulo também apresenta importantes entraves para o desenvolvimento e a disseminação de inovações na CPIC, estando relacionados principalmente à característica singular e de grande variabilidade do produto da construção civil e aos riscos e incertezas inerentes à inovação e à própria atividade de construção, devido principalmente aos extensos prazos de execução. 
Ao buscar caminhos e diretrizes para o desenvolvimento e a disseminação de inovações aplicadas à Indústria da Construção, o capítulo identificou os tipos, a exemplo das inovações que afetam o processo construtivo (considerada mais adequada aos objetivos da pesquisa), os requisitos e os processos para tal finalidade, sendo que para o último caso merece destaque o modelo proposto por Blumenschein (2004).

Esse modelo, após identificar os principais vetores de influência para a inovação da CPIC (Produção, Demanda, Tecnologia e P\&D e o Empreendedor Líder), faz uma associação entre a CPIC e um organismo vivo, identificando como unidade básica desse organismo (CPIC) a célula (empresas e entidades das diversas cadeias), que por sua vez é responsável pela introdução de um novo código genético (inovação) que induza a mudança de comportamento de todo o organismo; e está fundamentado em cinco passos: Planejamento, Separação de um grupo de células, Preparação de um meio apropriado e condições de cultura, Indução do Gene, Monitoramento e avaliação.

Enquanto que o modelo de Blumenschein (2004) atribui o papel da célula à Cadeia Principal, devido a sua capacidade de determinar o comportamento de outras cadeias, a presente pesquisa, utilizando o mesmo conceito da célula como agente catalizador do processo de inovação, atribui ao Estado esse papel, seguindo a proposição de Mazzucato (2014) devido à capacidade de demanda e investimento e à capacidade de suportar os riscos inerentes ao processo de inovação.

Tal fato indica a necessidade de analisar o processo de planejamento e contratação das obras públicas, já que, ao considerar o papel do Estado como agente de inovação, identificou-se que existe maior eficácia quando o Estado faz a encomenda de soluções e tecnologias que exigem inovação em comparação à distribuição de subsídios ao setor produtivo em troca de soluções inovadoras (MAZZUCATO, 2014).

O segundo tema abordado pelo capítulo, o Planejamento de Obras Públicas, é consequência da relação entre a necessidade de inovação na CPIC e a importância e capacidade de atuação do Estado nesse setor. Dessa forma, buscou-se analisar e caracterizar o evento Obra Pública e as fases que o compõem a fim de identificar os entraves e as oportunidades de inovação.

A obra pública consiste em um evento administrativo composto por cinco fases preliminar, interna, externa, contratual e posterior - e que resulta em uma construção, reforma, recuperação ou ampliação de um bem público - monumento, edificação ou infraestrutura; podendo ser realizada de maneira direta, quando a execução é realizada 
pelo próprio órgão ou entidade beneficiária, ou de maneira indireta, quando os serviços necessários à materialização da obra são realizados por terceiros.

A partir do conceito de obra pública, exposto anteriormente, identifica-se a necessidade de Licitação como regra em se tratando da execução indireta, sendo esse um procedimento formal e obrigatório nos casos definidos em lei. A licitação também pode ocorrer na contratação de serviços técnicos, a exemplo dos projetos de arquitetura e das demais especialidades, quando não for possível a realização deles pelo corpo técnico da entidade contratante.

Dada à importância da fase preliminar dentro do processo da obra pública, buscouse dentro do arcabouço jurídico relacionado às contratações de serviços por licitação a lei que melhor estivesse adequada ao caso de necessidade de contratação de serviços para elaboração de projeto que considere todas as etapas, do estudo preliminar ao projeto executivo.

Dessa forma observou-se que a lei federal 8.666/93, a lei geral da licitação, foi a única que abordou a contratação de projeto conforme a circunstância posta pela pesquisa e apresenta os critérios de avaliação, "melhor técnica" e "técnica e preço", mais condizentes com a natureza desses serviços.

Também é importante destacar a relação de vinculação existente entre a viabilidade do processo licitatório com a garantia da melhor escolha do objeto licitação e qualidade dos instrumentos licitatórios, documentos responsáveis pela formalidade exigida ao processo e pela exteriorização das necessidades da administração públicas e das regras e requisitos a serem atendidos pelos postulantes à contratação.

Para a devida elaboração dos instrumentos licitatórios, foi identificada a necessidade de se observar alguns conceitos de maneira mais ampla, a exemplo da avaliação do custo que deve considerar, além dos custos de projeto e execução, as fases de operação e demonstre ou descarte do empreendimento e seus componentes e sistemas, além dos impactos no orçamento e na gestão pública.

Outro conceito a ser ampliado é a produtividade, que deve ir além da composição de custo das tarefas e passar a ser considerada como princípio de planejamento a fim de garantir o cumprimento dos prazos vinculados à disposição dos recursos públicos e das obrigações financeiras da gestão pública.

Outro conceito importante para o planejamento das obras públicas é o referente à Sustentabilidade que é exigida inclusive por determinações legais, a exemplo das leis 
8.666/93 e 12.462/2011 e das Instruções Normativas $n^{\circ} 05$ e n ${ }^{\circ} 01$ - sendo que essa última trata especificamente de práticas sustentáveis para obras públicas.

Dada a representatividade das obras públicas, a sua consequente capacidade de induzir a inovação de processos e produtos na cadeia produtiva da construção civil, a responsabilidade do setor público com a sustentabilidade legalmente instituída e a importância dos instrumentos licitatórios na determinação dos produtos e serviços adquiridos pela administração pública, a presente pesquisa tem o objetivo de identificar e analisar a presença de fatores que permitam a utilização de sistemas construtivos industrializados em obras públicas.

Diante do exposto, o presente capítulo contribui para a identificação e definição do objeto de estudo ao indicar as demandas estatais como vetor de influência para o processo de inovação na CPIC, ao caracterizar o processo de contratação de serviços técnicos e obra para edificações públicas e ao mostrar a legislação que melhor se adequa à situação analisada pelo trabalho bem como os documentos que deverão ser analisados pelos estudos de caso. 


\section{CONSTRUÇÃO INDUSTRIALIZADA}

Com o objetivo de justificar a importância do processo de industrialização da construção civil como vetor de inovação e identificar a melhor forma de inseri-lo no contexto nacional, este capítulo tem como objetivo apresentar o conceito de Construção Industrializada, analisando a evolução histórica e importantes definições para que se chegue a um modelo adequado à realidade brasileira.

O capítulo também expõe a relevância da utilização de sistemas construtivos industrializados na industrialização da construção, além de identificar e classificar os principais sistemas utilizados no contexto nacional e apresentar seus principais atributos a fim de auxiliar na elaboração do modelo de industrialização da construção.

\subsection{Conceito de Construção Industrializada}

A partir do entendimento de que a arquitetura e a construção civil são formas de expressão humana e, portanto, suscetíveis a influências sociais, científicas, comportamentais e de outras manifestações do conhecimento do homem, é possível identificar as relações existentes entre o desenvolvimento e sofisticação dos modos de produção no século XX e a forma de pensar e materializar a arquitetura.

Seguindo esse raciocínio, Lessing (2006) cita a influência que o modo de produção Fordista-Taylorista do início do Século XX exerceu sobre a ideia de industrialização até a metade desse século, inclusive quando relacionado à construção civil, estando ele relacionado principalmente ao ganho de produção, introduzindo conceitos importantes como a padronização e a modularização, além da mecanização.

Já Fabrício (2013) trata a Industrialização da Construção como um dos pressupostos do Modernismo. Para o autor "a estrutura independente, a fachada sem adornos, a predileção pela linha reta, o uso de novos materiais, como aço e concreto armado, representam não só uma estética da sociedade industrial, mas são tidos como base para a industrialização da própria produção da Arquitetura".

Fabrício (2013) ainda destaca o paradoxo existente entre as obras modernas, dotadas de soluções estéticas e materiais industriais alinhadas com o paradigma industrial, e a sua convivência com um modo de produção artesanal; além do processo de industrialização tardia no contexto brasileiro, implantado significativamente na década de 1960, dentro projeto desenvolvimentista nacional.

Esse processo de industrialização tardia na década de 1960 foi desenvolvido pela produção habitacional estatal em larga escala com o advento do Sistema Financeiro da 
Habitação (SFH); sendo esse processo de industrialização apontado como inconcluso, devido à permanência do caráter artesanal do canteiro de obras.

Para Bruna (1976) os fatores determinantes para a industrialização da construção no contexto europeu - a grande demanda por habitações, escassez de recursos financeiros disponíveis e da mão de obra especializada e a necessidade de racionalizar os recursos construtivos - foram os mesmos que determinaram a busca pela industrialização da construção no Brasil.

Fabrício (2013) aponta que a evolução do paradigma da industrialização da construção ocorreu de forma aberta, de modo que o paradigma industrial contemporâneo não é tão hegemônico e coeso como o fordista-taylorista, sendo possível identificar duas abordagens principais, ainda que complementares: uma que é referente às automações e ao emprego de máquinas na produção e a outra baseada na utilização de técnicas de racionalização fundamentadas na produção enxuta (Lean Construction).

De fato, a busca por um conceito de industrialização da construção uniformemente empregado no contexto contemporâneo é complexa, haja vista a diversidade de interpretações e entendimentos sobre o que de fato significa a industrialização da construção. Diante da evolução do conceito de industrialização e dos diferentes contextos em que se deu essa evolução, é possível identificar alguns conceitos que podem nortear a formulação de um entendimento contemporâneo sobre o tema.

Sendo assim, a pesquisa identificou alguns conceitos importantes elaborados em momentos distintos e que podem demonstrar a evolução dos conceitos de industrialização da construção e auxiliar na uniformização do entendimento atual da questão, sendo eles expostos a seguir com a identificação do autor e do ano de publicação.

a) Blachère (1977) e Rosso (1980)

Ainda sob a influência do fordismo e com um pequeno espaço de tempo entre as publicações, os entendimentos de Blachére e Rosso se mostraram bastante semelhantes, sendo que para ambos a industrialização da construção consiste na substituição da produção artesanal pela utilização de tecnologias (ou máquinas automatizadas).

Rosso (1980) ainda propõe a existência de dois tipos de industrialização: a Industrialização Fechada ou de Ciclo Fechado, caracterizada pela exclusividade dos modelos de produto e da produção por parte da indústria; e a Industrialização Aberta ou de Ciclo Aberto, mais flexível e caracterizada pela combinação diversificada de componentes pré-fabricados, sendo as composições entre os componentes de domínio irrestrito. 
Segundo Ribeiro (2002), tanto industrialização de ciclo aberto quanto a de ciclo fechado são formas de alcançar a construção industrializada. Para o autor, o sistema de produção industrial aberto corresponde à produção de componentes industrializados, ao passo que no sistema fechado ocorre a produção de unidades arquitetônicas completas.

Segundo Oliveira (2013), a industrialização de Ciclo Aberto é mais flexível e caracterizada pela produção de componentes pré-fabricados que podem ser combinados de maneiras diversas a fim de compor uma construção, garantindo ao arquiteto grande liberdade para criação. O que contraria o senso de que construções que adotam o princípio da construção industrializada tendem a ser monótonas.

b) Koskela (1992)

Influenciado pelo Toyotismo, filosofia de produção originada no Japão com foco no gerenciamento das atividades e dos recursos e na qualidade do produto, por meio do sistema de administração Just in Time (na hora certa) relacionado à produção por demanda, Koskela (1992) apresenta o que ele denominou de "Nova filosofia da Produção" aplicada à construção.

Essa teoria tem como base a importância do aspecto gerencial no processo de industrialização, por meio da integração das atividades de planejamento e por meio de um entendimento holístico do processo construtivo, considerando a existência de atividades que não agregam valor ao produto a fim de minimizá-las e até extingui-las, tratando assim da racionalização do processo como meio para a industrialização.

c) Mac Donnell (1999)

Para Mac Donnel (1999), o processo de industrialização da construção consiste em “produzir edificações substituindo a mão de obra artesanal com máquinas utilizadas por operários especializados em seu manejo, ou máquinas automáticas", tendo seu foco na mecanização, na automação e na racionalização. Observa-se, portanto, uma aproximação desse conceito com a ideia clássica de industrialização e com os dois conceitos iniciais.

Mac Donnell (1999) ainda propõe a medição do grau de industrialização, que indica a qualidade do tipo de industrialização adotado pela obra. $\mathrm{O}$ índice de industrialização fundamenta-se principalmente no fator tempo, considerando o tempo de fabricação e transporte em horas-homem por área de superfície útil e o tempo de execução em obra.

Destaca-se ainda que o índice proposto por Mac Donnell não representa a mensuração da produtividade ou eficiência na utilização dos recursos disponíveis. Porém sua aplicação permite comparar os modos de produção da construção civil quanto ao grau de industrialização. 
Conforme o índice proposto, o menor resultado é apresentado pela construção artesanal, seguido pela construção tradicional evoluída, procedimentos racionalizados, pré-moldados, pré-fabricação aberta, pré-fabricada fechada e, finalmente, a préfabricação industrial convencional, que por sua vez representa o nível de industrialização, conforme indicado na figura 03.

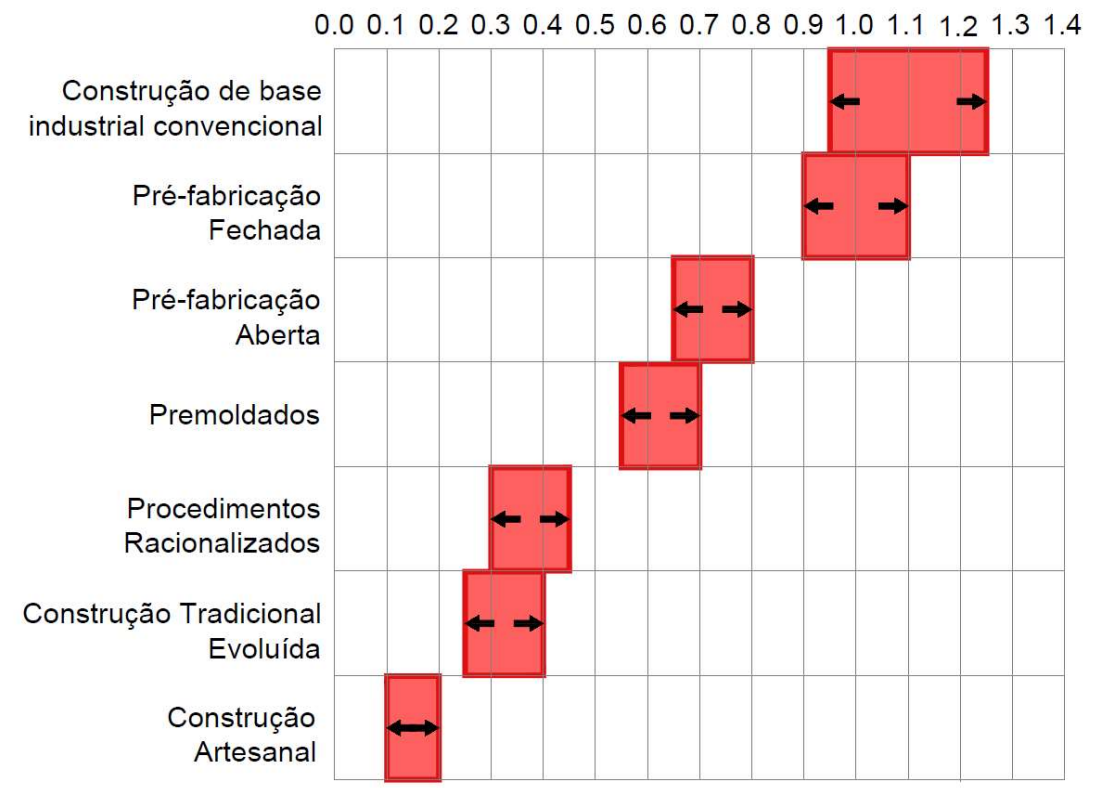

Figura 3. Níveis de Industrialização. Fonte: Adaptado de Mc Donnell (1999)

d) Lessing (2006)

Lessing (2006) propõe que um novo conceito de industrialização aplicado à construção foi iniciado por volta do ano 2000, relacionado com a necessidade de desenvolvimento com o objetivo de reduzir custos, melhorar qualidade e desenvolver métodos de produção.

Esse conceito teve como fatores chave a pré-fabricação da construção aliada a sistemas construtivos disponíveis no mercado, soluções de Tecnologia da Informação (TI) e logística, aferindo às duas últimas uma importância fundamental para o sucesso do processo de industrialização.

Lessing (2006) também aponta que a inspiração desse novo conceito industrial da construção provém do paradigma da construção enxuta (Lean Construction), que se atém à organização dos processos e suas atividades, devendo ele ter como foco principal as necessidades e prioridades dos clientes.

Embora reconheça na pré-fabricação de sistemas e componentes construtivos uma parte importante e central no processo de industrialização da construção, Lessing (2006) destaca a importância de manter um entendimento e uma visão holística do processo 
construtivo, propondo que - além da pré-fabricação - a "Padronização", a "Tecnologia da Informação", o "Desenvolvimento do Produto" e o "Processo construtivo" também sejam identificados como elementos da industrialização da construção.

Para Lessing (2006), a industrialização da construção pode ser definida como "um processo de construção completamente desenvolvido com uma organização bem adaptada para uma gestão eficiente, preparação e controle das atividades, fluxos, recursos e resultados para os quais componentes altamente desenvolvidos são utilizados para criar o máximo valor ao cliente".

No conceito de construção industrializada de Lessing, os aspectos organizacionais e tecnológicos devem ser igualmente desenvolvidos para alcançar a industrialização. Esse conceito se caracteriza pelo aspecto cíclico, indicado na figura 04 , ao contrário da linearidade da construção convencional, e agregam 08 (oito) áreas, colocadas a seguir:

1. Planejamento e controle de processos:

Diz respeito à necessidade de planejar todas as atividades do processo construtivo o mais cedo possível e à atenção extra que deve ser dispensada aos projetos, de arquitetura e engenharias, e ao planejamento e a preparação da produção a fim de obter ganhos de produtividade e qualidade e reduzir os erros e desperdícios (LESSING, 2006).

2. Sistemas tecnicamente desenvolvidos:

A utilização dos sistemas tecnicamente desenvolvidos tem o objetivo de minimizar os defeitos e criar um processo efetivo. Esse item também está relacionado à utilização dos sistemas construtivos industrializados em diversos níveis de flexibilidade, inclusive em soluções para as instalações e fachadas.

3. Manufatura off-site de partes da edificação:

O presente item pode ser considerado como a materialização do item anterior, uma vez que trata da produção de partes da edificação em ambiente fabril com equipamentos avançados e que proporcionem alto nível de acabamento a fím de minimizar o trabalho no canteiro de obra, onde essas partes serão devidamente combinadas e montadas.

4. Relações de longo prazo entre participantes (partes envolvidas - clientes, técnicos, fornecedores e executores):

Por ser um processo que envolve diversos participantes com diferentes atribuições, a industrialização da construção deve ser organizada a partir do estabelecimento de boas condições de cooperação entre os envolvidos a fim de 
alcançar os objetivos comuns e fornecer a máxima agregação de valor ao produto oferecido ao cliente (LESSING, 2006).

5. Logística integrada ao processo construtivo:

Uma vez que se opta por soluções construtivas que são fabricadas fora do canteiro de obra, se faz necessário um correto planejamento da logística entre a cadeia de suprimentos, os responsáveis pelo transporte e a obra.

6. Foco no Cliente:

Tem o objetivo de assegurar que o produto correto, com a qualidade correta e com o custo correto sejam produzidos conforme as necessidades e prioridades do cliente, bem como do consumidor final, devidamente investigadas e analisadas (LESSING, 2006).

7. Utilização da Tecnologia da Informação:

A utilização de ferramentas de tecnologia da informação (TI) é necessária ao processo de industrialização da construção, uma vez que este requer informações precisas e confiáveis, que por sua vez têm origens diversas dos vários agentes envolvidos nesse processo. Dessa forma, essas ferramentas auxiliam na organização, armazenamento e troca dessas informações.

8. Mensuração sistemática de desempenho e reutilização de experiências:

Dado o aspecto cíclico do processo de industrialização da construção, as informações obtidas pela mensuração de desempenho e das experiências e lições aprendidas no empreendimento atual devem ser utilizadas no desenvolvimento de soluções e processos para os empreendimentos futuros.

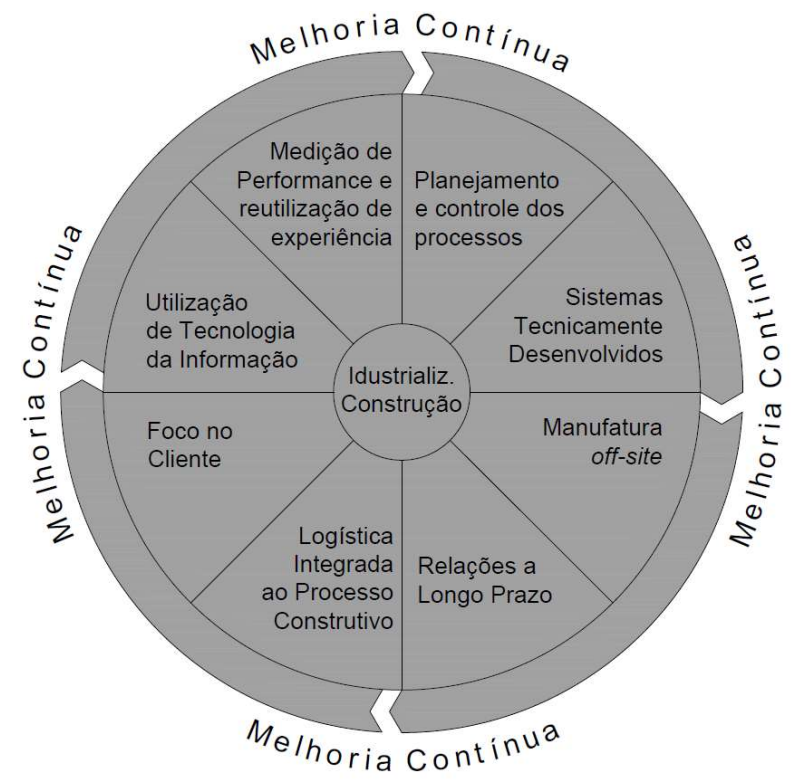

Figura 4. Processo de Construção Industrializada. Fonte: Adaptado de Lessing (2006) 
e) Kamar et al. (2009)

Kamar et al. (2009) retoma a importância da produção em massa de sistemas construtivos industrializados, produzidos em fábrica ou ambiente controlado, porém associando a utilização desses sistemas à questão da logística e da instalação e com a necessidade de uma coordenação adequada ao planejamento e à integração sistemática entre os envolvidos (KAMAR et al., 2011).

Apesar da proximidade com o conceito clássico de industrialização, fica bastante clara a importância dada ao planejamento e à gestão processual no processo de industrialização, o que representa uma interseção com as ideias mais recentes sobre a industrialização da construção e uma evolução do conceito clássico.

f) Fabrício (2013)

Fabrício (2013) apresenta o conceito de "Industrialização Flexível”, que consiste na utilização integrada de técnicas gerenciais e tecnologias digitais de projeto e de produção, com o objetivo de melhorar a produtividade, a qualidade e a sustentabilidade dos edifícios ao longo do seu ciclo de vida (do projeto ao desmonte).

Percebe-se que o conceito de industrialização proposto por Fabrício (2013) não está atrelado à utilização de sistemas construtivos industrializados e possui foco na Gestão e na utilização de tecnologias digitais tanto na elaboração do projeto e do planejamento quanto da produção e na integração das diversas atividades e competências envolvidas no processo construtivo.

g) Malmgren (2014)

A definição de industrialização da construção para Malmgren (2014) significa um processo racionalmente coordenado, sem a obrigatoriedade do desenvolvimento de uma nova tecnologia, embora isso possa ser uma consequência ou um pré-requisito desse processo. Seguindo o raciocínio de Lessing (2006), também aponta a importância do cliente no processo de industrialização.

A visão de Malmgren (2014) sobre a industrialização da construção também reside em uma abordagem sistemática fundamentada na relação aberta e colaborativa entre as partes envolvidas (stakeholders), cujo foco está nos processos e na utilização da tecnologia, além de citar a importância do aprendizado com experiências anteriores.

h) ABDI (2015)

Em publicação recente, voltada para a contratação de sistemas construtivos industrializados, a Agência Brasileira de Desenvolvimento Industrial (ABDI) aborda a industrialização da construção como a representação do mais elevado estágio de 
racionalização dos processos construtivos, associando-a à produção dos componentes em ambiente industrial e à posterior montagem em canteiro de obra (ABDI, 2015).

Diante do exposto, fica clara uma evolução das reflexões sobre o significado da Construção Industrializada. O conceito evoluiu partindo da ideia que restringia a industrialização ao fato de substituir o artesanato pela máquina, até chegar à noção de associar a industrialização ao gerenciamento dos processos, embora conceitos recentes retomem o conceito de construção industrializada vinculada à mecanização dos processos de produção dos sistemas e à montagem em canteiro, conforme ilustrado no Quadro 01 .

\begin{tabular}{|c|c|c|c|c|}
\hline \multicolumn{5}{|c|}{ Definições Construção Industrializada } \\
\hline Autor & Ano & Definição & Palavras-Chave & Observações \\
\hline Blachère & 1977 & $\begin{array}{l}\text { "A industrialização é o uso de tecnologias que substituem a } \\
\text { habilidade do artesão através do uso de máquinas" }\end{array}$ & Mecanização & \\
\hline Rosso & 1980 & \begin{tabular}{|l|} 
"Industrial é o método que, entre várias modalidades de \\
produção, é baseado essencialmente em processos \\
organizados de natureza repetitiva e nos quais a \\
variabilidade incontrolável e casual de cada fase de \\
trabalho, que caracteriza as ações artesanais, é substituída \\
por graus pré-determinados de uniformidade e \\
continuidade executiva, característica das modalidades \\
operacionais parcial ou totalmente mecanizadas"
\end{tabular} & $\begin{array}{l}\text { Racionalização, } \\
\text { Repetição, } \\
\text { uniformidade, } \\
\text { continuidade, } \\
\text { mecanização }\end{array}$ & $\begin{array}{l}\text { Influência da industrialização clássica de } \\
\text { Taylor: Subsituição de artesanato por } \\
\text { máquinas }\end{array}$ \\
\hline Koskella & 1992 & $\begin{array}{l}\text { Nova Filosofia de Produção: "Em essência, a nova } \\
\text { conceituação implica numa dupla visão de produção: isso } \\
\text { consiste em conversões e fluxos...enquanto todas as } \\
\text { atividades gastam custos e consumem tempo, apenas as } \\
\text { atividades de conversão agregam valor ao material ou a } \\
\text { uma informação que está sendo transformada em um } \\
\text { produto. Assim, a melhoria das atividades de fluxo deve ser } \\
\text { tornada mais eficiente." }\end{array}$ & Gestão & $\begin{array}{l}\text { A Nova Filosofia de Produção possui } 11 \\
\text { princípios, entre os principais constam a } \\
\text { redução da variabilidade, redução do tempo } \\
\text { de ciclo, Simplificar a quatitidade de } \\
\text { atividades, Aumento da flexibilidade de } \\
\text { saídas, aumento de transparência. }\end{array}$ \\
\hline Mc Donnell & 1999 & $\begin{array}{l}\text { "Produzir edificações substituindo a mão de obra artesanal } \\
\text { com máquinas utilizadas por operários especializados em } \\
\text { seu manejo, ou com máquinas automáticas" }\end{array}$ & $\begin{array}{l}\text { Mecanização, } \\
\text { Automação, } \\
\text { Racionalização }\end{array}$ & $\begin{array}{l}\text { Mais próximo do conceito clássico de } \\
\text { industrialização da construção / Apresenta } \\
\text { os graus de industrialização / Classificação } \\
\text { dos sistemas (acrescentar item no cap. 02) }\end{array}$ \\
\hline Lessing & 2006 & $\begin{array}{l}\text { "é um processo de construção completamente } \\
\text { desenvolvido com uma organização bem adaptada para } \\
\text { uma gestão eficiente, preparação e controle das } \\
\text { atividades, fluxos, recursos e resultados para o qual } \\
\text { componentes altamente desenvolvidos são utilizados para } \\
\text { criar o máximo valor ao cliente" }\end{array}$ & $\begin{array}{l}\text { Gestão, } \\
\text { Componentes, } \\
\text { Valor Agregado }\end{array}$ & $\begin{array}{l}\text { Aspectos organizacionais e tecnológicos } \\
\text { igualmente desenvolvidos para alcane da } \\
\text { industrialização / Conceito agrega } 08 \text { áreas } \\
\text { (1. Planejamento e controle, } 2 \text {. Sistemas } \\
\text { tecnicamente desenvolvidos,3. Manufatura } \\
\text { off-site , 4. relações de longo prazo, } 5 . \\
\text { Logística integrada, } 6 \text {. Foco no consumidor, } \\
\text { 7. Utilização ICT, 8. Medição de } \\
\text { performance e reutilização de experiências) }\end{array}$ \\
\hline Kamar et al. & 2009 & $\begin{array}{l}\text { "É a técnica construtiva na qual componentes são } \\
\text { manufaturados em ambiente controlado (ou fora do } \\
\text { canteiro), transportado, posicionado e montado em uma } \\
\text { estrutura com o mínimo de trabalho adicional em } \\
\text { canteiro" }\end{array}$ & $\begin{array}{l}\text { Manufatura, } \\
\text { Montagem, } \\
\text { Sistemas } \\
\text { (Componentes) }\end{array}$ & $\begin{array}{l}\text { Mais próximo do conceito clássico de } \\
\text { industrialização da construção }\end{array}$ \\
\hline Fabrício & 2013 & $\begin{array}{l}\text { "Industrialização Flexível - Emprego integrado de técnicas } \\
\text { gerenciais e tecnologias digitais de projeto e de produção, } \\
\text { de forma a ampliar a produtividade, a qualidade e a } \\
\text { sustentabilidade dos edifícios ao longo do seu ciclo de vida } \\
\text { (Projeto, construção, uso, manutenção e desmonte)" }\end{array}$ & $\begin{array}{l}\text { Gestão (Técnicas } \\
\text { Gerenciais), } \\
\text { Tecnologias digitais } \\
\text { (Projeto + } \\
\text { Produção) e } \\
\text { Integração }\end{array}$ & $\begin{array}{l}\text { Não atrela o conceito de industrialização da } \\
\text { construção à utilização de sistemas } \\
\text { construtivos industrializados - Foco no } \\
\text { processo / Gestão (Industrialização por } \\
\text { projeto) }\end{array}$ \\
\hline ABDI & 2015 & $\begin{array}{l}\text { Industrialização da contrução como representação do } \\
\text { maior estágio de racionalização dos processos contrutivos, } \\
\text { associado à pré-fabricação dos componentes }\end{array}$ & $\begin{array}{l}\text { Racionalização, } \\
\text { pré-fabricação }\end{array}$ & $\begin{array}{l}\text { Associação entre racionalização dos } \\
\text { processos e pré-fabricação de componentes } \\
\text { e elementos }\end{array}$ \\
\hline
\end{tabular}

Quadro 1: Definições de Construção Industrializada - Parte 01. 
Embora não seja o conceito mais recente, a industrialização da construção como uma associação de diversos segmentos de ordem técnica e gerencial apresenta-se como o mais completo, uma vez que agrega a pré-fabricação e a gestão dos agentes e das atividades, adicionando o foco nos parâmetros de qualidade e satisfação ofertados aos clientes e a necessidade de utilizar ferramentas de TI nas diversas etapas desse processo.

Dessa forma, o conceito elaborado por Lessing (2006) foi considerado o mais completo, justamente por identificar os diversos fatores que contribuem para o sucesso da industrialização, superando a limitação da simples substituição do artesanato pela máquina e reconhecendo a importância dos sistemas construtivos industrializados, apesar de entendê-los como parte do processo construtivo industrializado e não sua totalidade.

\subsection{Aspectos do processo construtivo industrializado}

ABDI (2015) aponta que o processo construtivo que utiliza sistemas construtivos industrializados deve ser planejado de maneira peculiar, considerando quatro aspectos inerentes à produção desses sistemas, são eles:

- Produção dos elementos em fábrica: Uma vez que os sistemas construtivos industrializados são concebidos e produzidos em um sistema fabril, faz-se necessário a participação direta de projetistas e das organizações envolvidas no processo produtivo na concepção do produto a fim de diminuir problemas de produção e de incompatibilidade na montagem em obra e garantir o atendimento satisfatório das soluções de projeto da edificação.

- Contratação: Diferencia-se da construção convencional por agregar projeto nesse caso, dos elementos e componentes - e execução em um só contrato, sendo também necessária a realização de um contrato para montagem dos elementos em obra.

- Tributação: Uma vez que são produzidos em fábrica, os elementos e componentes dos sistemas construtivos industrializados são comercializados como produtos e não como serviços, diferentemente do que acontece com a construção convencional - onde o processo de transformação de insumos em produtos acabados é realizado por serviços dentro do canteiro. Dessa forma, tributações específicas da produção e comércio de produtos são aplicadas a esses sistemas, tais como o ICMS - relacionado à circulação de mercadoria - e o IPI que tributa produtos industrializados, e devem ser consideradas durante as etapas de viabilidade prévia e orçamentação. 
- Arranjos de Processos Produtivos Diferenciados: Esse aspecto trata da necessidade de relacionar características do empreendimento com os princípios básicos da industrialização e atributos inerentes dos sistemas construtivos industrializados a serem adotados como soluções técnicas, tais como a redução da variabilidade dimensional dos componentes e a facilidade de combinação entre eles, o que destaca a importância da coordenação modular de todo o sistema e das soluções de interface entre diferentes componentes de diferentes materiais.

\subsection{Sistemas Construtivos Industrializados}

Conforme exposto anteriormente, mesmo as teorias que excluem a necessidade da utilização de sistemas construtivos industrializados reconhecem a importância desses sistemas para o sucesso da industrialização da construção. Essa importância está relacionada aos atributos desses sistemas, que permitem principalmente ganhos de qualidade e produtividade.

\subsubsection{Definição de Sistema Construtivo}

Para Brasil (1995), Sistema Construtivo corresponde ao conjunto de elementos construtivos que quando associados e coordenados dão origem a um todo lógico, podendo existir elementos que constituem em si um sistema. O autor ainda trata dos subsistemas como partes do sistema construtivo, sendo eles formados por componentes e materiais de construção organizados e compatibilizados no projeto a fim de cumprir os requisitos e critérios funcionais e construtivos exigidos para a edificação.

Brasil (1995) aponta quatro subsistemas principais: subsistema estrutural, que condiciona os demais subsistemas; subsistema cobertura, também considerado um subsistema rígido; subsistem vedações, interage diretamente com o subsistema estrutural e é um condicionante para a flexibilidade espacial; subsistema de instalações, responsável pela complexidade e funcionamento da edificação.

A NBR 15.575-1/2013, norma que trata do desempenho de edificações residenciais, define sistema como o "conjunto de elementos e componentes destinados a cumprir com uma macrofunção que a define" - a exemplo da fundação, estrutura, vedações verticais, instalações e cobertura - sendo ele considerado a maior parte funcional do edifício.

A NBR 16.636-1/2017, referente às atividades técnicas para elaboração e desenvolvimento de projetos arquitetônicos e urbanísticos, conceitua "Sistema como conjunto de elementos e respectivos componentes destinados a cumprir uma função. 
Já a NBR 9062/2006, que trata do projeto e execução de estruturas em concreto prémoldado, "Elemento pré-fabricado" como aquele executado em ambiente industrial, ainda que em instalações temporárias em canteiros de obra, ou em instalações permanentes de empresa cuja finalidade seja a produção e fornecimento desses elementos e que atenda aos requisitos mínimos de qualificação de mão de obra.

A partir dos conceitos anteriores, entende-se por sistema construtivo industrializado a associação de componentes produzidos a partir de materiais diversos em ambiente industrial, a partir de processos mecanizados, dotados de maior rigor técnico e requisitos superiores de regularidade e qualidade, e posteriormente transportados e montados no canteiro de obra.

De grande importância para a implementação da construção industrializada, os sistemas construtivos industrializados caracterizam-se pela padronização e maior exigência quanto a precisão de seus componentes, bem como pela flexibilidade de produção, seja em larga escala por repetição seja pela produção de peças individuais conforme a necessidade do projeto, graças ao alto nível de mecanização do processo de fabricação e montagem. Essas características acabam determinando a necessidade de maior precisão do projeto e capacitação da mão de obra.

Outra nomenclatura com a finalidade de diferenciar os sistemas construtivos industrializados dos sistemas construtivos convencionais, tais como alvenarias e outros modelados in situ, é a utilizada no contexto do Reino Unido, que adota o termo Métodos Modernos de Construção (MMC).

Housing Corporation (2006) apresenta o MMC como um termo coletivo utilizado para descrever cinco métodos construtivos, classificados da seguinte forma: Préfabricados Volumétricos, referente à construção modular - onde uma unidade arquitetônica é completamente produzida em fábrica; Pré-fabricados Panelizados, relacionado à fabricação de superfícies - totalmente acabadas ou semi-prontas e de materiais diversos - cujas principais funções são de vedação, cobertura e piso; Préfabricados Híbrido, também chamado de semi-volumétrico - uma vez que utiliza sistemas volumétricos para a produção de ambiente ou partes de uma edificação feita com a utilização de outros tipos de sistemas, tais como os panelizados; Pré-fabricados - Submontagem e componentes, consiste tanto na pré-fabricação de componentes individuais a serem montados e combinados no canteiro de obras quanto na produção de subsistemas inteiros ou parte deles em fábrica para montagem posterior em canteiro - a exemplo de módulos de coberturas e módulos estruturais pré-fabricados; e Fabricados no canteiro 
com métodos modernos, referente à utilização de componentes convencionais de maneira inovadora, sendo semelhante aos processos racionalizados de sistemas convencionais.

\subsubsection{Classificação dos SCI}

Diante da exposição dos conceitos e caracterizações da construção industrializada e dos sistemas construtivos industrializados a presente pesquisa classifica esses sistemas da seguinte forma:

- Quanto ao Uso: Relacionado com o conceito e classificação proposto por Weidle, os sistemas construtivos são classificados conforme a função que desempenham da edificação em sistemas estruturais, de cobertura, de vedação e de instalação, podendo essa última abranger instalações aplicadas às obras de sistemas de infraestrutura.

- Quanto à Topologia: Diz respeito à forma apresentada pelos elementos e suas associações e tem origem na classificação proposta na descrição dos Métodos Modernos de Construção. Dessa forma os sistemas construtivos industrializados estão classificados em sistemas volumétricos, Panelizados, Híbridos, Associação de componentes.

- Quanto à origem: Essa classificação está relacionada com o processo de produção dos elementos e componentes dos sistemas construtivos, sendo ela dividida em sistemas pré-fabricados - produzidos em ambiente fabril - e sistemas racionalizados - produzidos de forma sistemática, porém no próprio canteiro de obras ou em ambiente improvisado.

\subsection{Principais Sistemas Construtivos Industrializados utilizados no Brasil}

Apesar do contexto nacional quanto à utilização de sistemas construtivos industrializados se apresentar como abaixo do almejado, o Brasil detém uma oferta considerável quanto a variedade e capacidade de produção desses sistemas.

Conforme ABDI (2015), os principais sistemas construtivos para estruturas, cobertura e vedações são os sistemas construtivos em Aço, Steel Frame, Drywall, Concreto Pré-fabricado e Wood-frame, sendo eles caracterizados a seguir quanto ao uso, a seus atributos e exigências projetuais e de planejamento:

\subsubsection{Sistemas Construtivos em Aço:}

O aço consiste em uma liga metálica constituída basicamente por ferro e carbono e obtida por processo industrial altamente rigoroso, que garante a homogeneidade da liga e sua confiabilidade; e sendo classificado como um material isótropo, que possui resistência semelhante a solicitações estruturais diferentes, o aço é considerado igualmente eficiente em utilizações para esforços de tração e compressão, sendo a tração simples a que melhor se adapta às suas características (RABELLO, 2000). 
Algumas características atribuídas ao aço, que proporcionam vantagens em sua utilização na construção civil, são a esbeltez das peças, atribuídas à elevada massa específica, além da elasticidade, ductilidade - as peças em aço sofrem grandes deformações antes de seu rompimento - e a tenacidade - capacidade de absorção de energia quando submetidos a cargas de impacto (MATTOS, 1997).

Os sistemas construtivos em aço são caracterizados pelo alto nível de mecanização no processo de fabricação, que garantem a padronização e a precisão dos componentes e a flexibilidade de composições, já que possibilita adição de novos elementos sem danos ou maiores intervenções na estrutura existente.

Os sistemas construtivos em aço são utilizados principalmente em Fundações, a exemplo de estacas pré-fabricadas; Superestruturas, tanto em sistemas esqueleto - a utilização de pilares, vigas e treliças pré-fabricados - quanto na produção de pórticos e outros elementos estruturais pré-fabricados; Pisos em lajes steel-deck; Estruturas Especiais, tais como pontes e torres; Coberturas e na produção de Componentes específicos, a exemplo de tirantes, cabos e montantes.

Os atributos destes sistemas permitem ganhos qualitativos e econômicos na produção de edificações, estando relacionados, sobretudo, com o menor tempo de execução, chegando a reduzir até $40 \%$, bem como impacto positivo considerável quanto ao desperdício de materiais. Estes ganhos estão atrelados a maiores investimentos em planejamento para pleno sucesso em sua utilização (ABDI, 2015).

Outros aspectos positivos de sistemas estruturais em aço são as propriedades de desmontagem e reaproveitamento de componentes e reciclagem da matéria-prima, além do fato de ser 100\% reciclável (ABDI, 2015). Lemoine [ca. 2002] afirma que $40 \%$ da produção do aço no mundo é realizada a partir da reciclagem, o que reduz o impacto na extração de matéria-prima.

O sucesso da implementação dos sistemas construtivos em aço está relacionado a requisitos de projeto e de planejamento, tais como a necessidade de soluções racionalizadas, de detalhamento das ligações entre os diversos componentes e da interface com outros sistemas e a devida compatibilização entre os projetos das diferentes especialidades envolvidas.

A produção industrial dos sistemas em aço implica na necessidade do planejamento da logística entre a cadeia de suprimentos e a obra bem como na elaboração de um plano de montagem ainda na etapa de projeto, devendo ser dada atenção à utilização de 
equipamentos específicos no processo de montagem e ao impacto financeiro referente à aquisição desses equipamentos (ABDI, 2015).

Vale destacar ainda que as propriedades físicas, químicas e mecânicas do aço podem levar à necessidade de tratamentos específicos dos componentes a fim de melhorar a resistência deles quanto a situações e agentes específicos, tais como a resistência ao fogo e à corrosão, devendo essas questões serem contempladas durante o projeto e o planejamento da edificação.

\subsubsection{Light Steel Framing}

O Light Steel Framing (LSF) é um sistema construtivo de concepção racional, caracterizado pela estrutura formada pela associação de perfis de aço galvanizado formados a frio, utilizados para composições de painéis estruturais e não-estruturais, sendo também conhecido como um Sistema Estrutural de Construção a Seco (SANTIAGO et al. 2012).

Quando projetado para suportar as cargas da edificação, o LSF funciona como um sistema autoportante para edificações até 08 pavimentos; já quando é aplicado em associação com outros subsistemas, funciona geralmente como subsistema de vedação, piso ou cobertura, podendo ainda ser utilizados na produção de módulos volumétricos, tanto para unidades arquitetônicas quanto para cômodos pré-fabricados (ABDI, 2015).

Dentre os atributos do LSF, destacam-se a possibilidade de utilização de diversos materiais para vedação dos painéis em aço e a flexibilidade de uso e facilidade de associação com outros subsistemas estruturais - tais como o aço, o concreto e a madeira - já que não apresenta grandes restrições quanto a soluções projetuais (ABDI, 2015).

Consequência do rigor do processo industrial de fabricação das peças que compõem o LSF, esse sistema é caracterizado pela padronização dos componentes e pela qualidade de acabamento de suas peças e assim como do resultado final da montagem em obra, que também é consequência do maior rigor dimensional do sistema.

A racionalização também se configura como um importante atributo do Light Steel Framing. Vivan et al. (2010) destaca que a execução de obras em LSF utiliza componentes industrializados que já estão aptas, mediante determinações de projeto, a compor a edificação sem a necessidade de atividades de conversão paralelas à montagem, diminuindo assim a necessidade de tarefas sem agregação de valor na obra.

A leveza dos componentes também é um aspecto bastante positivo do LSF quanto a logística, permitindo maior facilidade no transporte das peças entre a fábrica e o 
canteiro; e a viabilidade da montagem, que pode dispensar a necessidade de equipamentos especiais para movimentação dos componentes e elementos na obra.

O LSF ainda é caracterizado pela durabilidade de seus componentes, por utilizar uma execução a seco a partir da utilização exclusiva de peças industrializadas, e por possibilitar a customização dos diversos componentes a fim de atender a requisitos específicos da obra, tais como resistência ao fogo e a reações químicas, e melhores condições de conforto térmico e acústico.

A partir dos atributos apresentados, é possível identificar alguns requisitos de projeto e de planejamento fundamentais para a viabilidade executiva das edificações em Light Steel Framing, como é o caso da adoção de soluções projetuais racionalizadas. Segundo CBCA (2013), recomenda-se a utilização de medidas com módulos de 1,20 m a fim de se tirar maior proveito do sistema, identificando-se aí também a necessidade da adoção do conceito de coordenação modular.

Uma vez que as atividades de conversão dos componentes do LSF são a priori feitas em ambiente fabril, fora do canteiro, há uma necessidade intrínseca de um alto grau de detalhamento das peças e com grande precisão das suas dimensões, bem como do detalhamento quanto a interface do LSF com outros subsistemas.

Também é importante que o projeto das edificações em LSF contemple a visão de montagem da edificação a partir da elaboração de um projeto para produção, a fim de garantir a produtividade, a eficiência quanto a gestão dos recursos e materiais empregados na obra e, consequentemente, a redução de desperdício.

Faz-se importante ainda a previsão em projeto dos tratamentos e customizações referentes à obtenção de propriedades específicas pelo sistema, tanto por meio da adição de materiais quanto de componentes - tais como a aplicação de pinturas especiais ou de mantas e vedações especiais, respectivamente.

\subsubsection{Drywall}

O Drywall é um sistema construtivo estruturado em perfis de aço com fechamento em placas de gesso acartonado e, diferentemente do Light Steel Framing, não possui função estrutural, sendo utilizado para divisórias internas, vedações e forros, podendo ainda ser utilizado como revestimento de acabamento em paredes de alvenarias tradicionais por meio do processo de colagem das placas de gesso acartonado diretamente nas paredes com a utilização de massa (ABDI, 2015). 
O Drywall possui alguns dos atributos apresentados pelo sistema LSF, tais como a padronização dos componentes, a leveza e facilidade transporte e de montagem - que pode ser feita sem a necessidade de equipamentos especiais, a racionalização e a construção a seco - que refletem em ganhos de produtividade e redução do desperdício de insumos.

Assim como o LSF, o Drywall tem como requisitos de projeto a necessidade do alto grau de detalhamento dos componentes utilizados e da interface do Drywall com outros subsistemas, a racionalização e modulação das soluções como condição de melhor aproveitamento dos atributos do sistema e a necessidade de tratamento de propriedades específicas, seja com a adição de componentes seja com a aplicação de materiais.

\subsubsection{Concreto Pré-fabricado}

As soluções em concreto pré-fabricado consistem na produção de elementos e componentes construtivos em fábricas, podendo essas serem implantadas, ainda que de forma temporária dentro do próprio canteiro, com todo o rigor técnico qualidade que implica a produção industrial.

Segundo ABDI (2015), “as soluções estruturais mais adotadas pela construção préfabricada são compostas por um ou mais dos sistemas: porticados, em esqueleto e de paredes estruturais, que por sua vez podem associados aos sistemas formados por pisos, de fachadas e sistemas celulares".

Acker (2002) aborda que as soluções estruturais em concreto pré-fabricado são compostas pelos seguintes sistemas básicos, de princípios de projeto semelhantes: Estruturas aporticadas, Estruturas em esqueleto, Estruturas em Painéis estruturais, Estruturas para pisos, Sistemas para Fachadas e Sistemas Celulares.

A aplicação dos sistemas em concreto pré-fabricado nas soluções arquitetônicas pode atender às seguintes funções: Fundações; Superestrutura, tanto sistema esqueleto (com pré-fabricação dos diferentes componentes independentemente) quanto sistemas porticados e paredes estruturais; Pisos, com utilização de diversas soluções (tais como lajes alveolares, maciças, perfil T e vigotas); Fachadas e divisórias, sejam elas estruturais ou simplesmente de vedação; Coberturas; Elementos arquitetônicos pré-fabricados, a exemplo de escadas e protetores solares para fachadas; Arquitetura volumétrica e componentes e elementos de infraestrutura.

Os principais atributos das soluções em concreto pré-fabricado são a possibilidade de grandes vãos e flexibilidade de uso, graças à alta resistência mecânica dos 
componentes; o menor tempo de execução, em função da pré-fabricação; o maior rigor dimensional e alto nível de precisão e menor índice de desperdício, graças ao nível de controle dos processos produtivos em ambiente industrial; e a diversidade de composições e variações formais, sendo essa última atribuída à plasticidade inerente ao concreto (ACKER, 2002).

Requisitos de projeto e planejamento necessários para a utilização de sistemas construtivos em concreto pré-fabricado são bastante semelhantes aos atribuídos para as soluções em aço, devendo ser contemplado nessas etapas a adoção de soluções racionalizadas, a fim de aproveitar ao máximo o rendimento dos sistemas; a necessidade detalhamento dos componentes e da interface com outros sistemas e elementos.

Também devem ser observados a elaboração de um projeto com visão de montagem e de um projeto para produção; o devido planejamento da logística integrado ao projeto; a compatibilização entre as diversas especialidades envolvidas e a previsão da utilização de equipamentos especiais no processo de montagem e deslocamento das estruturas em canteiro, devido às grandes dimensões e ao peso dos componentes.

\subsubsection{Wood Frame}

Conforme estabelecido pela Diretriz SINAT 005 (2011), o Wood Frame consiste em um sistema construtivo estruturado por peças leves em madeira maciça serrada com fechamento em chapas delgadas, podendo estas serem do tipo OSB (Oriented Strand Board), chapas de madeira compensada, outros chapas de madeira, placa de gesso acartonado para Dry Wall ou placa cimentícia.

Segundo ABDI (2015), o sistema construtivo wood frame nacional é resultado de um processo industrializado de fabricação de painéis estruturais para montagem de edificações, sendo que a partir de 2013 foi desenvolvido de Painéis fechados produzido em ambiente fabril com todos os elementos das camadas, incluindo a pré-montagem das diversas instalações, a exemplo das instalações elétrica e hidráulica.

O Wood Frame pode ser utilizado tanto como um sistema construtivo autoportante para edificações de até cinco pavimentos como associado a outros sistemas estruturais, funcionando como subsistemas de vedação, interna ou externa, e subsistemas de piso.

Devido à similaridade de concepção com o sistema Light Steel Framing, o Wood Frame possui atributos semelhantes aos do sistema estruturados em perfis de aço, tais como a padronização dos componentes e qualidade de acabamentos decorrente da préfabricação, o alto rigor dimensional, a diversidade e flexibilidade de composições. 
Da mesma forma, o wood frame apresenta requisitos de projeto e de planejamento semelhantes ao LSF, a exemplo da necessidade de soluções racionalizadas, do alto grau de detalhamento, da compatibilização entre as diversas especialidades envolvidas no projeto, da recomendação de soluções modulares e da necessidade de tratamento quanto a propriedades por meio da adição de componentes e materiais.

A partir da apresentação dos principais sistemas construtivos industrializados, observa-se a existência de atributos em comum entre esses sistemas, tais como a redução do tempo de execução e do desperdício, a padronização de componentes e qualidade de acabamento, possibilidade de desmontagem e reaproveitamento e a flexibilidade.

Também há certa similaridade entre os requisitos de projeto e de planejamento dos sistemas construtivos industrializados apresentados, a exemplo da coordenação modular e da necessidade de soluções racionalizadas e do detalhamento das ligações entre componentes e da interface entre subsistemas, conforme exposto no Quadro 02.

\begin{tabular}{|c|c|c|}
\hline & & Atributos Sistemas Construtivos Industrializados \\
\hline \multirow{26}{*}{$\begin{array}{c}\text { Sistemas } \\
\text { em Aço }\end{array}$} & \multirow{6}{*}{ Principais Usos } & Super Estrutura - Sistema Esqueleto (Pilares / Vigas / Treliças) \\
\hline & & Pisos (Lajes - Steel Deck) \\
\hline & & Estruturas Especiais (Obras de Arte - Pontes, Torres) \\
\hline & & Fundações (Estacas Pré - fabricadas) \\
\hline & & Coberturas \\
\hline & & Componentes Específicos (Tirantes, Cabos, Montantes) \\
\hline & \multirow{12}{*}{ Atributos } & Pré-fabricação \\
\hline & & Maior Rigor Dimensional \\
\hline & & Grandes Vãos (Alta Resistência Mecânica) \\
\hline & & Menor Peso Próprio (Maior Esbeltez) \\
\hline & & Facilidade Transporte Compenentes (+ Compactos / + leves) \\
\hline & & Menor Tempo Execução (até 40\%) \\
\hline & & Menor Desperdício \\
\hline & & Reciclabilidade (100\% Reciclável) \\
\hline & & Adaptabilidade \\
\hline & & Desmontagem e reaproveitamento \\
\hline & & Diversidade / Flexibildade de composições \\
\hline & & Maior nível de precisão \\
\hline & \multirow{8}{*}{$\begin{array}{c}\text { Exigências } \\
\text { (Requisitos } \\
\text { Projeto / } \\
\text { Planejamento) }\end{array}$} & Soluções Racionalizadas \\
\hline & & Alto grau de Detalhamento - Ligações entre os diversos componentes \\
\hline & & Alto grau de Detalhamento - Interface com outros sistemas \\
\hline & & Projeto com visão da montagem \\
\hline & & Tratamento propriedades específicas (Resistência ao fogo e à corrosão) \\
\hline & & Planejamento da logística e da montagem (plano de montagem) \\
\hline & & Utilização de equipamentos específicos no processo de montagem \\
\hline & & Compatibilização \\
\hline
\end{tabular}

Quadro 2: Atributos e Requisitos dos SCI's (Parte 01). 


\begin{tabular}{|c|c|c|}
\hline & & Atributos Sistemas Construtivos Industrializados \\
\hline \multirow{23}{*}{$\begin{array}{c}\text { Light Steel } \\
\text { Framing }\end{array}$} & \multirow{4}{*}{ Principais Usos } & Estrutura Autoportante para edificações (até 08 pavimentos) \\
\hline & & Estrutura Cobertura \\
\hline & & Vedação (Interna / Externa) \\
\hline & & Arquitetura Volumétrica - Modular (Unidades Arquitetônicas / Cômodos \\
\hline & \multirow{12}{*}{ Atributos } & Pré-fabricação \\
\hline & & Padronização de Componentes \\
\hline & & Racionalizado \\
\hline & & Maior Rigor Dimensional \\
\hline & & Customizável \\
\hline & & Reciclabilidade (boa parte dos componentes) \\
\hline & & Autoportante \\
\hline & & Durabilidade \\
\hline & & Leveza dos Componentes (Facilidade Transp.) \\
\hline & & Facilidade de Montagem (Não é necessário equipamentos especiais) \\
\hline & & Construção a seco \\
\hline & & Diversidade / Flexibilidade de Composições \\
\hline & \multirow{7}{*}{$\begin{array}{c}\text { Exigências } \\
\text { (Requisitos } \\
\text { Projeto / } \\
\text { Planejamento) }\end{array}$} & Soluções Racionalizadas \\
\hline & & Alto Grau de Detalhamento - Precisão \\
\hline & & Alto grau de Detalhamento - Interface com outros sistemas \\
\hline & & Modulação (Coordenação Modular) \\
\hline & & Projeto com visão da montagem (Projeto para Produção) \\
\hline & & $\begin{array}{l}\text { Tratamento propriedades Específicas (Adição de Componentes e } \\
\text { Materiais) }\end{array}$ \\
\hline & & Compatibilização \\
\hline \multirow{23}{*}{$\begin{array}{l}\text { Wood } \\
\text { Framing }\end{array}$} & \multirow{4}{*}{ Principais Usos } & Estrutura Autoportante para edificações \\
\hline & & Estrutura Cobertura \\
\hline & & Vedação (Interna / Externa) \\
\hline & & Arquitetura Volumétrica - Modular (Unidades Arquitetônicas / Cômodos \\
\hline & \multirow{12}{*}{ Atributos } & Pré-fabricação \\
\hline & & Padronização de Componentes \\
\hline & & Racionalizado \\
\hline & & Maior Rigor Dimensional \\
\hline & & Customizável \\
\hline & & Reciclabilidade (boa parte dos componentes) \\
\hline & & Autoportante \\
\hline & & Durabilidade \\
\hline & & Leveza dos Componentes (Facilidade Transp.) \\
\hline & & Facilidade de Montagem (Não é necessário equipamentos especiais) \\
\hline & & Construção a seco \\
\hline & & Diversidade / Flexibilidade de Composições \\
\hline & \multirow{7}{*}{$\begin{array}{c}\text { Exigências } \\
\text { (Requisitos } \\
\text { Projeto / } \\
\text { Planejamento) }\end{array}$} & Soluções Racionalizadas \\
\hline & & Alto Grau de Detalhamento - Precisão \\
\hline & & Alto grau de Detalhamento - Interface com outros sistemas \\
\hline & & Modulação (Coordenação Modular) \\
\hline & & Projeto com visão da montagem (Projeto para Produção) \\
\hline & & $\begin{array}{l}\text { Tratamento propriedades Específicas (Adição de Componentes e } \\
\text { Materiais) }\end{array}$ \\
\hline & & Compatibilização \\
\hline
\end{tabular}

Quadro 2: Atributos e Requisitos dos SCI's (Parte 02). 


\begin{tabular}{|c|c|c|}
\hline & & Atributos Sistemas Construtivos Industrializados \\
\hline \multirow{13}{*}{ Dry Wall } & \multirow{2}{*}{ Principais Usos } & Divisórias \\
\hline & & Forros \\
\hline & \multirow{5}{*}{ Atributos } & Durabilidade \\
\hline & & Padronização de Componentes (Qualidade Acabamento) \\
\hline & & Facilidade de Montagem (Não é necessário equipamentos especiais) \\
\hline & & Construção a seco \\
\hline & & Leveza dos Componentes (Facilidade Transp.) \\
\hline & \multirow{6}{*}{$\begin{array}{c}\text { Exigências } \\
\text { (Requisitos } \\
\text { Projeto / } \\
\text { Planejamento) }\end{array}$} & Alto Grau de Detalhamento - Precisão \\
\hline & & Alto grau de Detalhamento - Interface com outros sistemas \\
\hline & & Modulação (Coordenação Modular) \\
\hline & & Projeto com visão da montagem (Projeto para Produção) \\
\hline & & Tratamento propriedades Específicas (Adição de Componentes e \\
\hline & & Compabilização \\
\hline \multirow{25}{*}{$\begin{array}{c}\text { Concreto } \\
\text { Pré - } \\
\text { fabricado }\end{array}$} & \multirow{9}{*}{ Principais Usos } & Super Estrutura - Sistema Esqueleto (Pilares / Vigas / Treliças) \\
\hline & & Pisos (Lajes - Perfil T, Alveoláres, Maciças, Vigota Pré-moldada) \\
\hline & & Paredes Estruturais (Diaframas - Núcleos Rígidos) \\
\hline & & Fachadas \\
\hline & & Coberturas \\
\hline & & Fundações (Estacas Pré - fabricadas) \\
\hline & & Elementos Arquitetônicos Pré-fabricado (Escadas \\
\hline & & Arquitetura Volumétrica - Modular (Unidades Arq. / Cômodos Inteiros) \\
\hline & & Infraestrutura \\
\hline & \multirow{9}{*}{ Atributos } & Pré-fabricação \\
\hline & & Maior Rigor Dimensional \\
\hline & & Grandes Vãos (Alta Resistência Mecânica) \\
\hline & & Menor Tempo Execução \\
\hline & & Menor Desperdício \\
\hline & & Possibilidade de Transporte (Componentes e elementos) \\
\hline & & Maior Plasticidade e variedade de elementos e componentes \\
\hline & & Diversidade de composições \\
\hline & & Alto nível de precisão \\
\hline & \multirow{7}{*}{$\begin{array}{c}\text { Exigências } \\
\text { (Requisitos } \\
\text { Projeto / } \\
\text { Planejamento) }\end{array}$} & Soluções Racionalizadas \\
\hline & & Alto grau de Detalhamento - Ligações entre os diversos componentes \\
\hline & & Alto grau de Detalhamento - Interface com outros sistemas \\
\hline & & Projeto com visão da montagem \\
\hline & & Planejamento da logística e da montagem (plano de montagem) \\
\hline & & Utilização de equipamentos específicos no processo de montagem \\
\hline & & Compatibilização \\
\hline
\end{tabular}

Quadro 2: Atributos e Requisitos dos SCI's (Parte 03).

\subsection{Modelo de Construção Industrializada (Base Pesquisa)}

Conforme apresentado anteriormente, essa pesquisa toma como modelo de Construção Industrializada o proposto por Lessing (2006), que permite aliar o aspecto de gestão do processo à utilização de sistemas construtivos industrializados e de ferramentas tecnológicas tanto na produção dos sistemas quanto no gerenciamento das diversas atividades e agentes do processo.

Esse modelo é fundamentado em 08 áreas - Planejamento e controle de processos, Sistemas tecnicamente desenvolvidos, Manufatura off-site de partes da edificação, Relações de longo prazo entre participantes, logística integrada ao processo construtivo, 
Foco no Cliente, Utilização da Tecnologia da Informação, Mensuração sistemática de performance e reutilização de experiências.

As 08 áreas que compõem o modelo de Lessing (2006) se relacionam de forma cíclica e contínua. Porém foi identificado, diante das peculiaridades da administração pública, fazer uma pequena alteração na ordem apresentada por Lessing (2006), de forma que o foco no cliente passa a anteceder o planejamento e controle dos processos e as relações a longo prazo a sucedê-lo, conforme indicado na Figura 05.

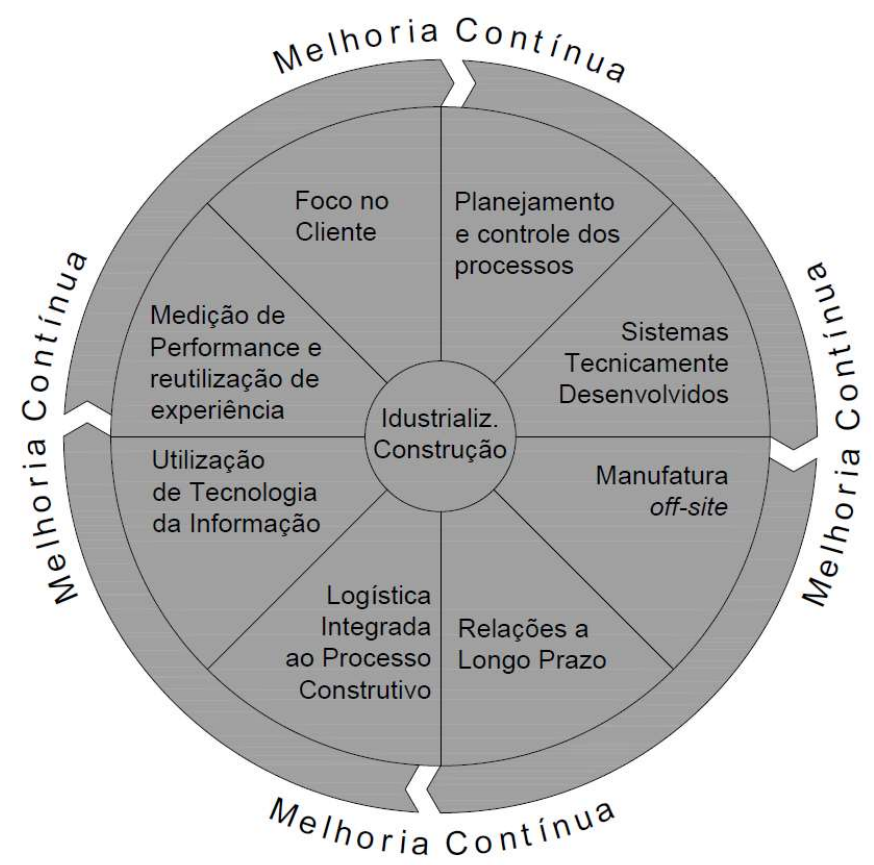

Figura 5. Modelo de Construção Industrializada Adaptado.

Diante do exposto, se faz necessário entender qual a finalidade e os requisitos de cada área dentro do processo de industrialização da construção e fazer a relação dessas áreas com as etapas do fluxo geral de uma obra pública apresentado por TCU (2013) a fim de identificar uma forma de integrar um processo cíclico, como a construção industrializada, com um processo linear, tal qual a obra pública, propondo assim um modelo de construção industrializada adequado à administração pública.

\subsubsection{Finalidades e requisitos das áreas do modelo de Construção Industrializada}

A primeira área a ser considerada é a correspondente ao Foco no Cliente, que no caso da aplicação em obras públicas, esse cliente corresponde à entidade contratante. É nessa área que devem ser claramente estabelecidas e analisadas as necessidades da administração pública.

Considerando a possibilidade de utilização de sistemas construtivos industrializados nas soluções futuramente propostas, deve ser realizada uma associação 
entre as necessidades da Administração Pública e os principais atributos e requisitos dos Sistemas construtivos industrializados, que serão detalhados de forma mais intensa na terceira área, sistemas tecnicamente desenvolvidos.

A área seguinte, que trata do Planejamento e controle de processos, é a responsável pela definição dos parâmetros e diretrizes para elaboração dos projetos técnicos e para as atividades posteriores, relacionadas à produção dos sistemas e à execução da obra propriamente dita - com a montagem dos sistemas em canteiro.

A área correspondente às relações de longo prazo diz respeito às exigências de requisitos na interação entre os agentes das diversas especialidades e para a compatibilização dos projetos correspondentes. Vale destacar que essas exigências devem ser levantadas ainda no planejamento dos processos que definirão os parâmetros e diretrizes do projeto.

Os Sistemas tecnicamente desenvolvidos correspondem à terceira área, onde ocorre o desenvolvimento dos projetos técnicos a partir das necessidades identificadas e da observação dos atributos dos sistemas construtivos industrializados. É nessa fase também que são ponderadas as vantagens e desvantagens dos diversos sistemas construtivos disponíveis e são analisadas as exigências ou requisitos de projeto dos Sistemas Construtivos Industrializados.

É também nessa área que devem ser observados aspectos do modo de produção industrializado apresentados anteriormente - a Produção em fábrica, a Contratação e a Tributação e os Arranjos de processos produtivos diferenciados.

A Manufatura Off-site corresponde à produção em fábrica dos sistemas e soluções previamente desenvolvidos, na qual ocorre a transferência de atividades de transformação e agregação de valor da cadeia principal para a cadeia de suprimentos.

A logística integrada ao processo de construção está relacionada com as exigências de projeto com vistas à produção e que considere a questão da logística entre a cadeia de suprimentos, agora responsável pela produção de parte considerável do empreendimento, e a obra propriamente dita. Destaca-se a necessidade de avaliar a logística ainda nas áreas anteriormente descritas.

A utilização da Tecnologia da Informação está relacionada com a interação entre as diversas especialidades técnicas e agentes produtivos envolvidos no processo de industrialização e corresponde à compatibilização, fluxo de informações e controle da produção através de ferramentas de TI, tais como a Tecnologia BIM e ferramentas de fabricação assistida. 
Por fim, a medição de desempenho e reutilização de experiência diz respeito à sistematização das informações e conhecimentos gerados de confrontação desses com as necessidades da entidade contratante, a fim de melhorar o andamento da produção da obra em curso e/ou auxiliar o planejamento de futuros empreendimentos, conforme demonstrado pela Figura 6, que também apresenta as demais áreas do modelo.

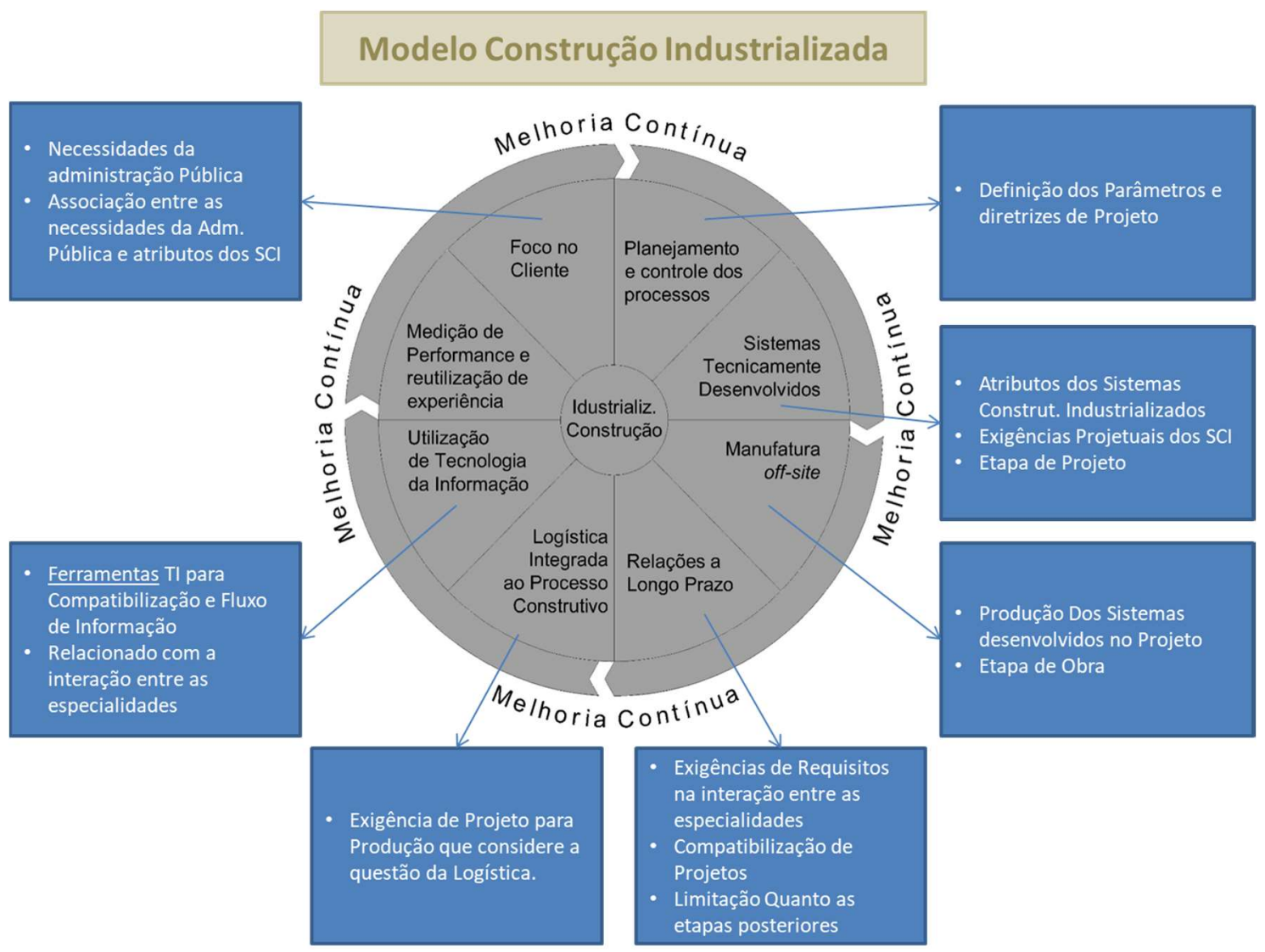

Figura 6: Detalhamento do Modelo Construção Industrializada.

\subsubsection{O modelo de construção industrializada dentro da obra Pública}

Sendo o modelo de Construção Industrializada adotado pela presente pesquisa um processo cíclico e contínuo e o evento obra pública uma sucessão linear de fases distintas, a relação entre esses dois processos é feita a partir da identificação da fase da obra pública onde deverá ser idealmente observada cada área que compõe o modelo de construção industrializada.

a) Fase Preliminar

A partir do entendimento das atividades e produtos resultantes de cada fase da obra pública, identificou-se que durante a fase preliminar - que está relacionada à elaboração do programa de necessidades, dos estudos de viabilidade, do planejamento preliminar e das etapas iniciais dos projetos técnicos - devem ser observadas as áreas referentes ao 
foco no cliente, ao planejamento e controle dos processos, aos sistemas tecnicamente desenvolvidos e às relações em longo prazo.

Vale destacar que a área referente aos sistemas tecnicamente desenvolvidos é iniciada durante a fase preliminar, devendo ser idealmente finalizada durante a fase interna de licitação, onde são desenvolvidos os projetos básico e executivo. Dessa forma, é na fase preliminar que os atributos e os requisitos dos sistemas construtivos industrializados deveram ser elencados e analisados a fim de avaliar a utilização desses sistemas como solução técnica.

Destaca-se também que os requisitos iniciais das relações à longo prazo e da utilização de ferramentas de TI são determinados na fase Preliminar. Deve-se observar ainda a possibilidade de utilização de dados e informações provenientes da área referente à medição de desempenho e reutilização de experiências prévias de empreendimentos anteriores que possam servir de parâmetro para o planejamento da obra em questão, conforme indicado na figura 07.
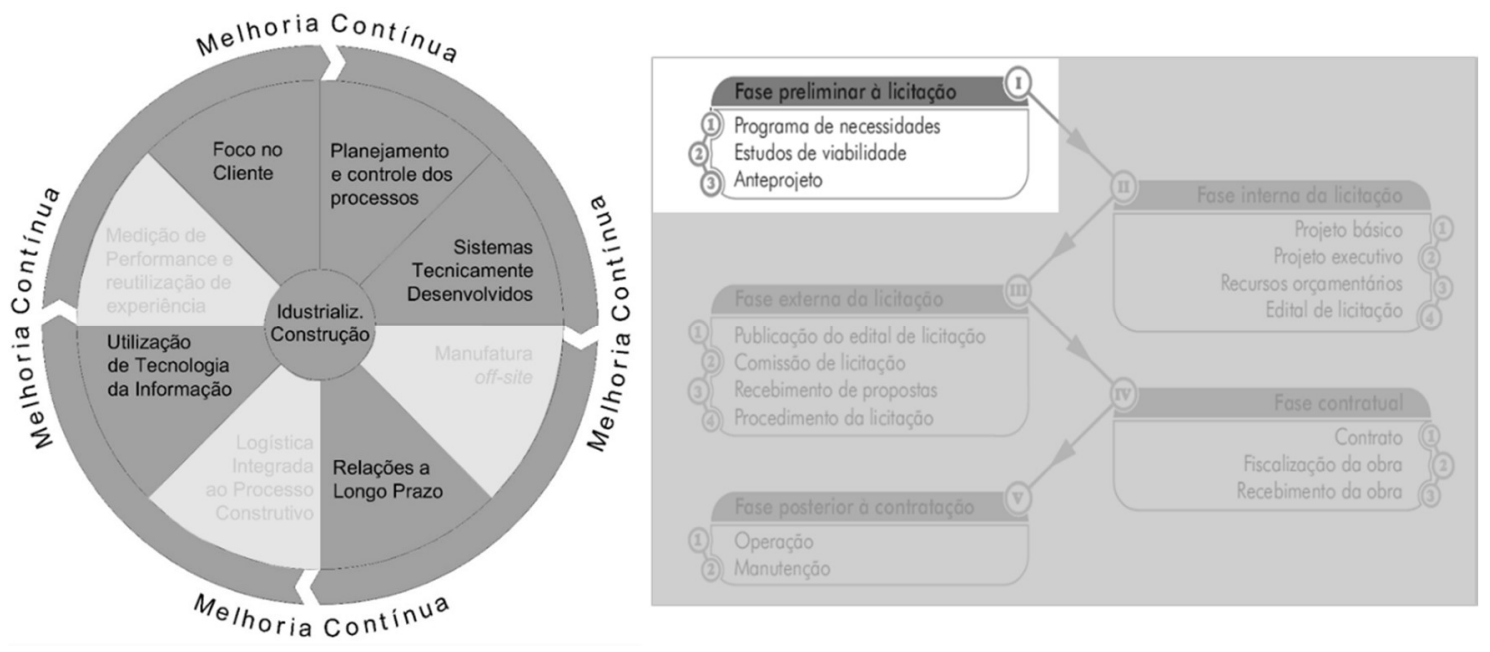

Figura 7. Fase Preliminar Obra Pública X áreas do processo de CI.

b) Fase Interna da Licitação

A Fase interna de Licitação, conforme abordado anteriormente, está relacionada com o desenvolvimento dos projetos técnicos, etapas de projeto básico e executivo, e com os preparativos para a licitação dos serviços de execução da obra; e como processo de construção industrializada transfere muitas das atividades de transformação e agregação de valor para o ambiente fabril, cadeia de suprimentos, se faz necessário observar nessa fase a área do processo de construção industrializada referente à logística integrada ao processo de construção, devendo ainda ser continuado o processo de planejamento e controle de processos - iniciado na fase anterior, conforme indicado na figura 08. 

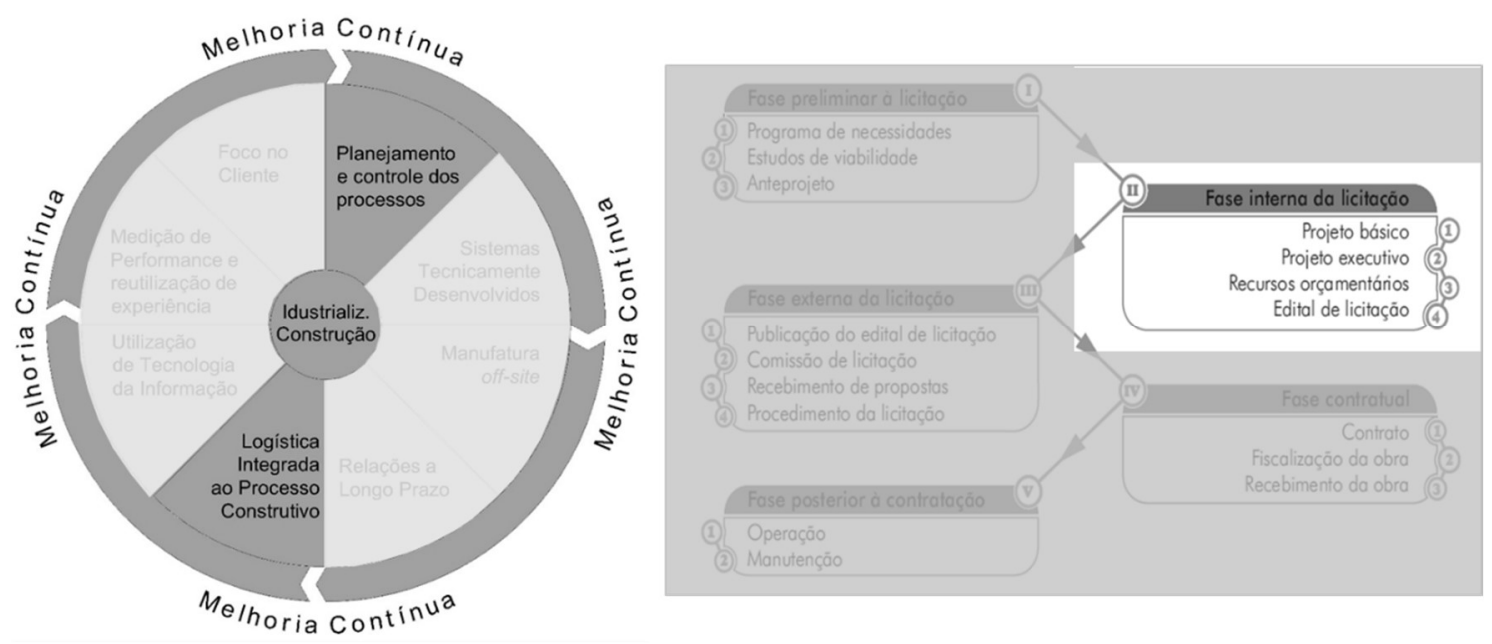

Figura 8. Fase Interna Obra pública X Áreas do processo de CI.

c) Fase Externa

Uma vez que a fase externa de licitação consiste em uma etapa burocrática e de formalização da contratação dos serviços e aquisições referentes à execução da obra pública, observa-se que é nessa fase que se materializa a contratação do fornecimento dos sistemas construtivos industrializados, dando início à área de manufatura off-site.

Observa-se também que as relações à longo prazo, previamente estabelecidas na fase preliminar, deverão ser aprofundadas e detalhadas, seguindo os parâmetros iniciais, a fim de dar prosseguimento à materialização do empreendimento em conformidade com o planejamento inicial, conforme indicado na figura 09.
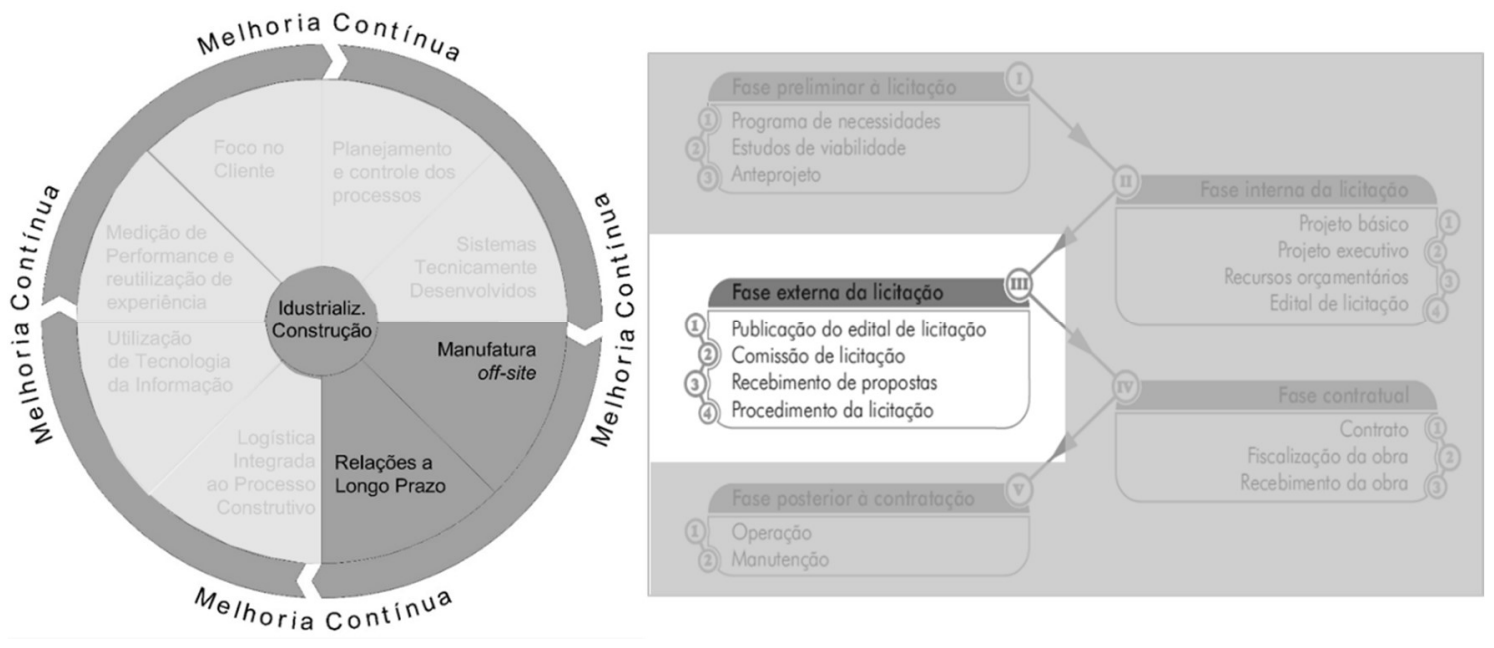

Figura 9. Fase Externa Obra pública X Áreas do Processo de CI.

d) Fase Contratual

$\mathrm{Na}$ fase contratual é onde ocorre a materialização do objeto do contrato, no caso a obra pública. Portanto é nessa fase que as atividades da área referente à manufatura offsite - fabricação, transporte e montagem - devem ocorrer. Também nessa fase que são 
postas em prática muitas das relações em longo prazo previamente estabelecidas, com destaque para as relações entre projetistas e fabricantes e entre esses e os agentes que atuam no canteiro de obras.

Nessa fase também ocorrem as atividades de logística previamente planejadas nas etapas anteriores, bem como é medida a desempenho e são levantados dados referentes ao processo construtivo, conforme indicado na figura 10.
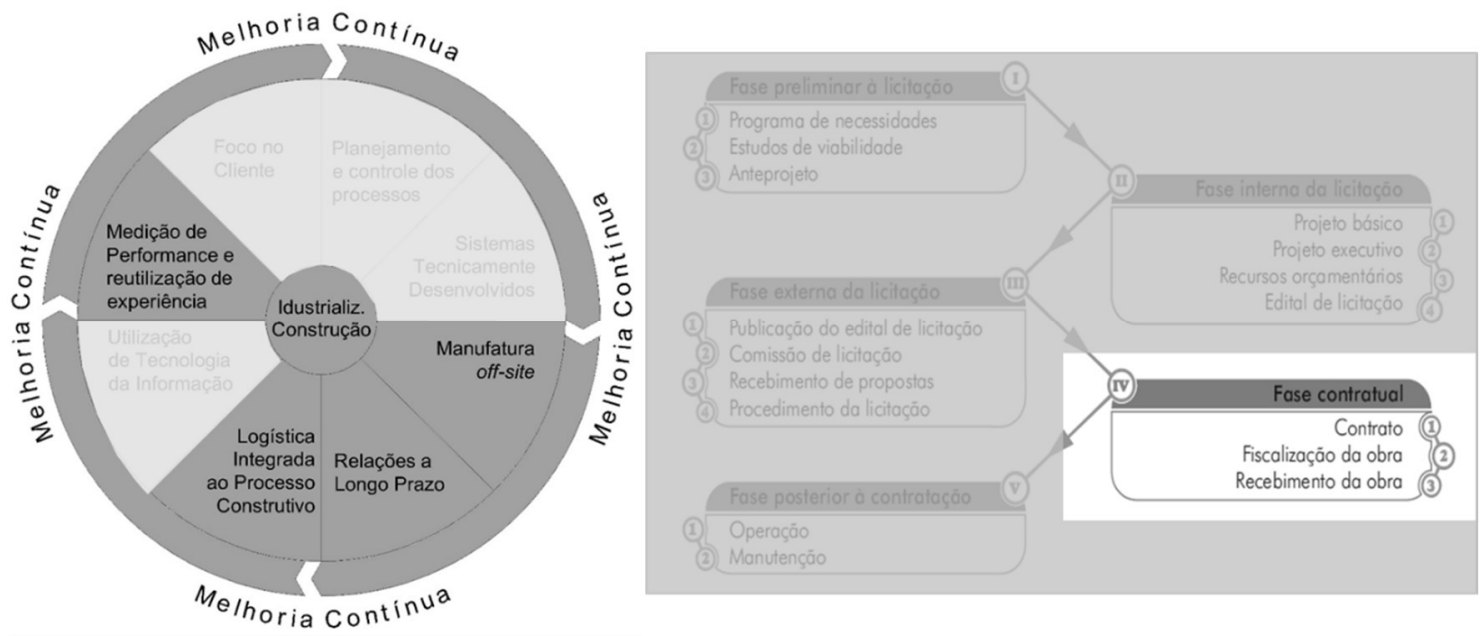

Figura 10. Fase Contratual Obra Pública X Áreas do Processo de CI.

e) Fase Posterior

Referente à fase de operação e manutenção do empreendimento, a Fase Posterior se atém, quanto ao modelo de construção industrializada, à área referente à mensuração de desempenho e reutilização de experiências para auxiliar no planejamento de futuros empreendimentos, a partir da observação e análise da edificação e coleta de dados.
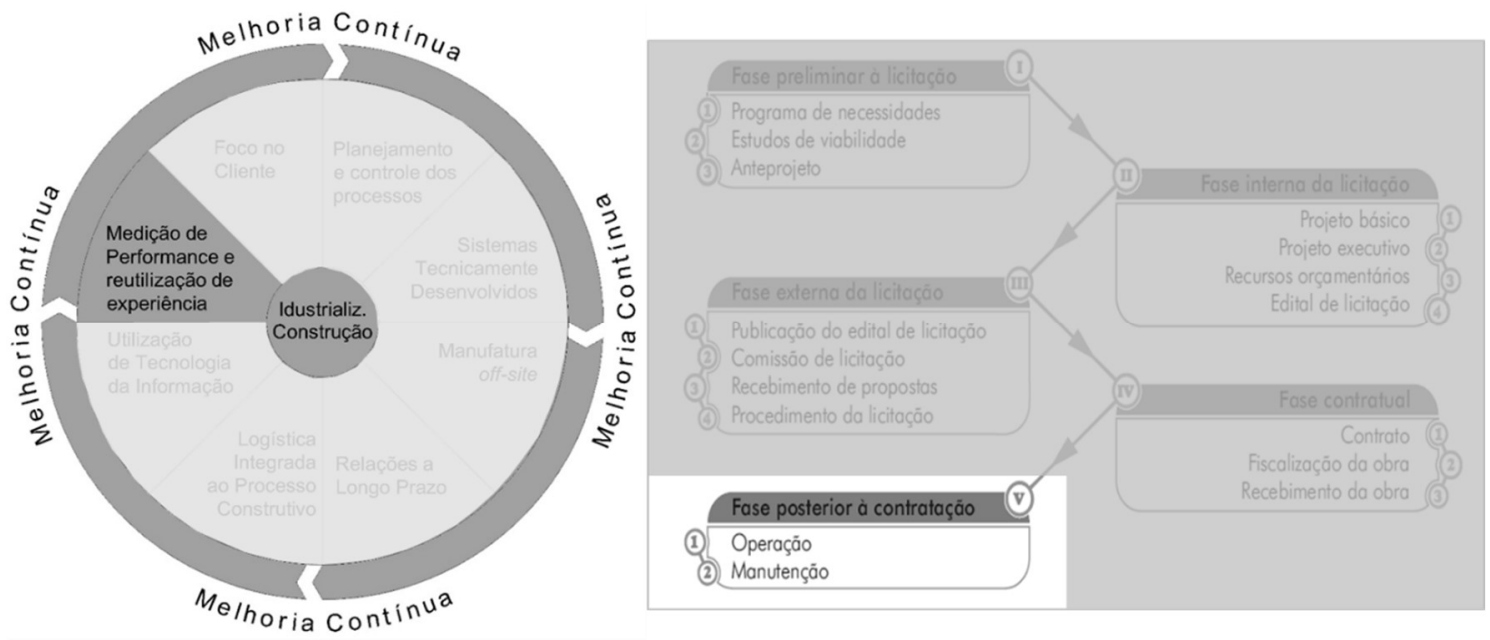

Figura 11: Fase Posterior Obra Pública X Áreas do Processo de CI.

Diante do exposto, observa-se que a fase preliminar concentra e dá início à maior parte das áreas do modelo de construção industrializada, sendo que é nessa fase que 
deverão ser analisados os atributos dos sistemas construtivos industrializados bem como a viabilidade de utilizá-los como solução dos projetos técnicos.

Em caso de elaboração dos projetos técnicos de forma indireta, através da contratação de terceiros, é importante que sejam estabelecidas as diretrizes e requisitos de projeto por parte da entidade contratante de forma que estejam alinhados às necessidades da administração pública e aos atributos e requisitos dos sistemas construtivos industrializados.

\subsection{Síntese analítica do capítulo}

A partir dos conceitos expostos no capítulo, compreende-se que a Construção Industrializada consiste na racionalização de processos construtivos com foco na qualidade e no atendimento às reais necessidades do cliente, aliada à utilização de sistemas construtivos industrializados e de tecnologias aplicadas à gestão e produção, gerando produtos caracterizados pela uniformidade e pela flexibilidade de composições.

Sendo parte fundamental para o processo de industrialização da construção, os sistemas construtivos industrializados são caracterizados pela padronização e precisão de seus componentes além da possibilidade da produção em larga escala ou de produção de peças individuais conforme a necessidade do objeto, resultado do alto nível de mecanização do processo de fabricação e montagem.

Os atributos dos sistemas construtivos industrializados permitem a obtenção de ganhos qualitativos e econômicos na produção de edificações, estando relacionados com menor tempo de execução e com o impacto positivo considerável quanto ao desperdício de materiais. Possibilitam ainda a redução do percentual de mão-de-obra no canteiro, se comparados com os sistemas construtivos convencionais, uma vez que ocorre a sobreposição das etapas na obra e na fábrica (ABDI, 2015).

Destaca-se ainda a relação direta entre os atributos dos sistemas construtivos industrializados, brevemente descritos acima, com o conceito de sustentabilidade ambiental, uma vez que os principais ganhos com a utilização da construção industrializada consistem no menor consumo e desperdício de materiais, na redução de resíduos gerados e de consumo de energia, além da otimização da mão de obra, na redução de retrabalhos.

A utilização de sistemas construtivos industrializados também traz outras implicações positivas, como ganhos em sustentabilidade social, ao promover melhores 
condições de trabalho através da melhoria em higiene e segurança da obra, e salto qualitativo na formação técnica do colaborador.

Outros atributos relacionados à sustentabilidade dos sistemas construtivos industrializados e suas consequentes vantagens também são abordados no capítulo, a exemplo da facilidade de expansão e da modificação de espaços internos da edificação, da possibilidade de desconstrução com alto índice de reaproveitamento dos componentes.

Determinadas particularidades dos sistemas construtivos industrializados também devem ser atentamente observadas quando se decide pela sua utilização - tais como a tributação diferenciada decorrente da sua natureza fabril (o que gera tributações específicas relacionadas à circulação de mercadorias e ao produto industrializado) e a forma de contratação (que pode considerar os projetos de detalhamento dos componentes, a fabricação, a montagem e a manutenção) (ABDI, 2015).

Por fim, destaca-se o processo de planejamento diferenciado dentro do conceito de construção industrializada, por ser caracterizado pela maior interação entre as especialidades, pelo maior rigor quanto aos aspectos dimensionais e de interface entre os componentes e sistemas distintos e pela maior necessidade da visão holística do objeto projetado como condição de resolução dos possíveis entraves causados pelas características anteriores.

A partir das considerações expostas anteriormente, o capítulo auxilia na justificativa do pressuposto da pesquisa que trata o processo de industrialização da construção como um caminho para uma evolução nos ganhos de produção e qualidade necessários à indústria da construção.

O capítulo contribui para a pesquisa ao propor uma associação entre o modelo de construção industrializada e o fluxo usual de uma obra pública e ao expor os principais atributos e aspectos a serem considerados pelos contratantes em um processo de tomada de decisão, ainda na fase preliminar de uma obra pública, quanto à escolha das soluções relacionadas ao sistema construtivo, sendo que esses atributos e aspectos poderão ser transformados em critérios e/ou diretrizes no desenvolvimento do trabalho. 


\section{METODOLOGIA}

O presente capítulo apresenta a metodologia utilizada pela pesquisa. Os passos metodológicos da pesquisa estão estruturados em quatro etapas (Figura 12), sendo a primeira referente à revisão bibliográfica dos conceitos que fundamentam o trabalho - a construção industrializada, a inovação na CPIC e a caracterização do processo de obras públicas - que correspondem aos capítulos 02 e 03 .

O segundo passo é referente ao desenvolvimento da ferramenta de pesquisa utilizada para a avaliação dos processos de contratação de projetos de arquitetura e demais especialidades e para o mapeamento dos processos de planejamento e tomada de decisão na etapa preliminar à licitação.

Já o terceiro passo metodológico corresponde à aplicação da ferramenta de pesquisa em estudos de caso, onde os instrumentos que compõem os processos de licitação são avaliados conforme os critérios que compõe a ferramenta.

Por fim, o quarto passo consiste na proposição de diretrizes para o planejamento de obras públicas adequado ao conceito construção industrializada e que proporcionem o aumento da utilização de SCI's nessas obras.

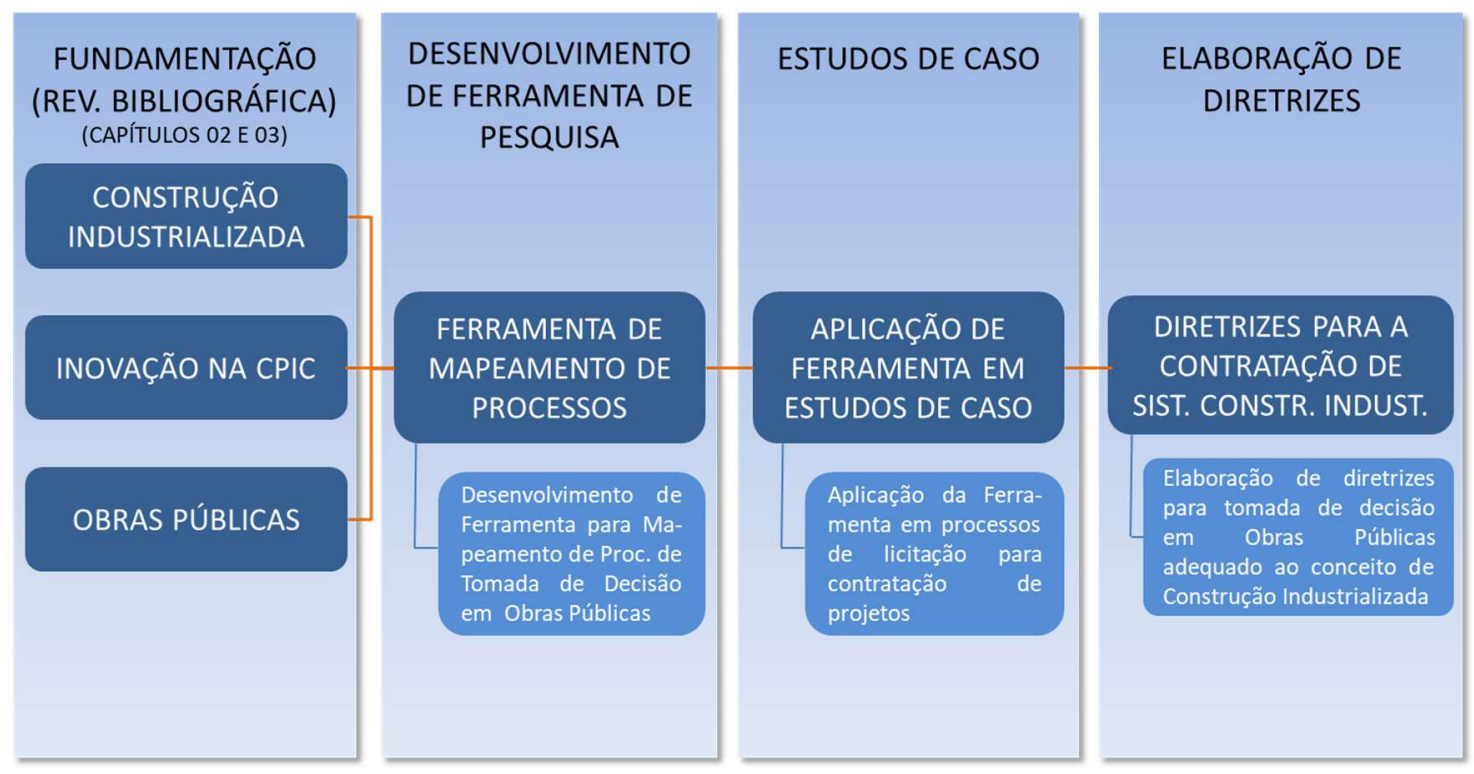

Figura 12: Passos Metodológicos

\subsection{Ferramenta Pesquisa - Avaliação de Instrumentos de Licitação}

A partir das considerações do item 2.2.3 do capítulo 02, que caracteriza a contratação de serviços técnicos pela administração pública, observa-se que a efetividade do processo de contratação dos projetos está diretamente relacionada à clareza dos objetivos e necessidades do ente público em relação à edificação pretendida e à qualidade dos instrumentos do processo de licitação. 
A qualidade desses instrumentos, por sua vez, está diretamente relacionada com a transcrição, de forma precisa e objetiva, dos anseios da entidade contratante; o que permite a obtenção dos subsídios técnicos para a prestação dos serviços contratados.

Ao contratar uma atividade propriamente técnica, como a elaboração de projetos, se faz necessário estabelecer critérios de avaliação que permitam a escolha mais acertada por parte da administração pública, independentemente da modalidade de licitação escolhida, e diretrizes que permitam caracterizar preliminarmente o objeto contratado, potencializando a execução efetiva dos serviços contratados.

Dessa forma, a pesquisa parte do pressuposto de que os critérios de avaliação e as diretrizes projetuais podem ser determinantes na escolha dos sistemas construtivos a serem empregados nas edificações públicas e que ao considerar certos critérios e diretrizes, característicos dos processos de construção industrializada, as decisões tendem para a utilização de sistemas construtivos industrializados.

Uma ferramenta de pesquisa foi elaborada em forma de tabela, baseada nos preceitos do Balanced Score Card e da Análise Multicritério (MCDA), com a finalidade de identificar a existência de critérios e diretrizes alinhados com o processo construtivo industrializado em instrumentos licitatórios para contratação de projetos e de identificar entraves e possíveis diretrizes para utilização de sistemas construtivos industrializados.

A construção conceitual da ferramenta parte da relação entre o modelo de construção industrializada proposto por Lessing (2006) e a caracterização das fases que compõem o evento obra pública por Brasil (2013), conforme exposto no item 3.5.2 do capítulo 03, que aponta quais são as áreas que compõem o modelo de construção industrializada e que devem ser observadas em cada fase da obra pública.

Sendo assim, a fase preliminar deve observar as áreas referentes ao foco no cliente, ao planejamento e controle dos processos, aos sistemas tecnicamente desenvolvidos (Sistemas Construtivos Industrializados) e às relações a longo prazo entre os agentes envolvidos, conforme indicado na Figura 7 - Capítulo 03. Portanto, é nessa fase que os atributos e requisitos dos sistemas construtivos industrializados e as particularidades do processo construtivo industrializado são observados. 


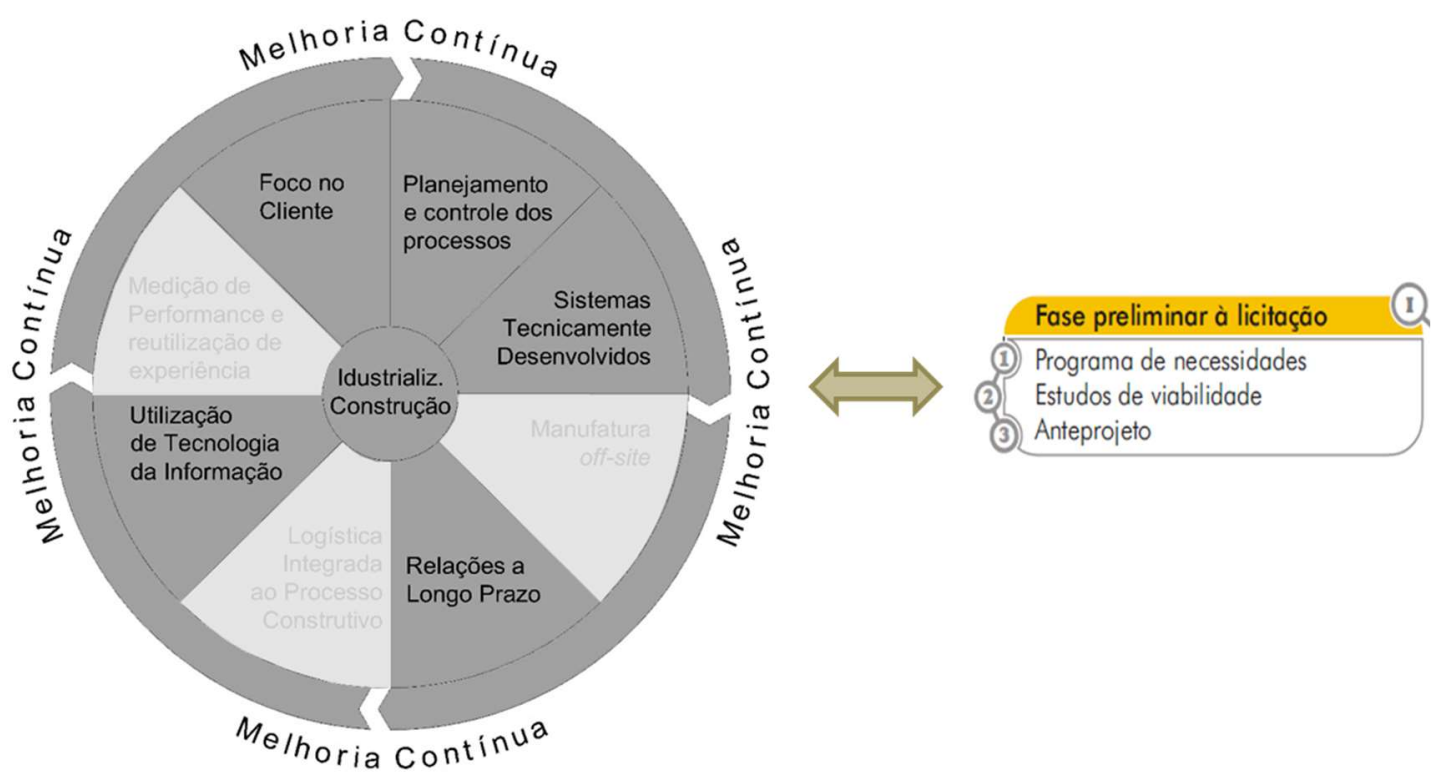

Figura 13 - Áreas do modelo de Construção Industrializada na fase preliminar de Licitação.

Dessa forma, os critérios que constituem a ferramenta são fundamentados a partir dos atributos e requisitos de projeto e planejamento dos sistemas construtivos industrializados bem como pelas particularidades ou aspectos do processo construtivo industrializado.

Esses atributos e requisitos e as particularidades são identificados e apresentados brevemente no item 3.4 do capítulo 03 e sintetizados no quadro 02 e apontados no item 3.2 do capítulo 03 - referente à produção dos elementos em fábrica e contratação, tributação e arranjos de processos produtivos diferenciados, respectivamente.

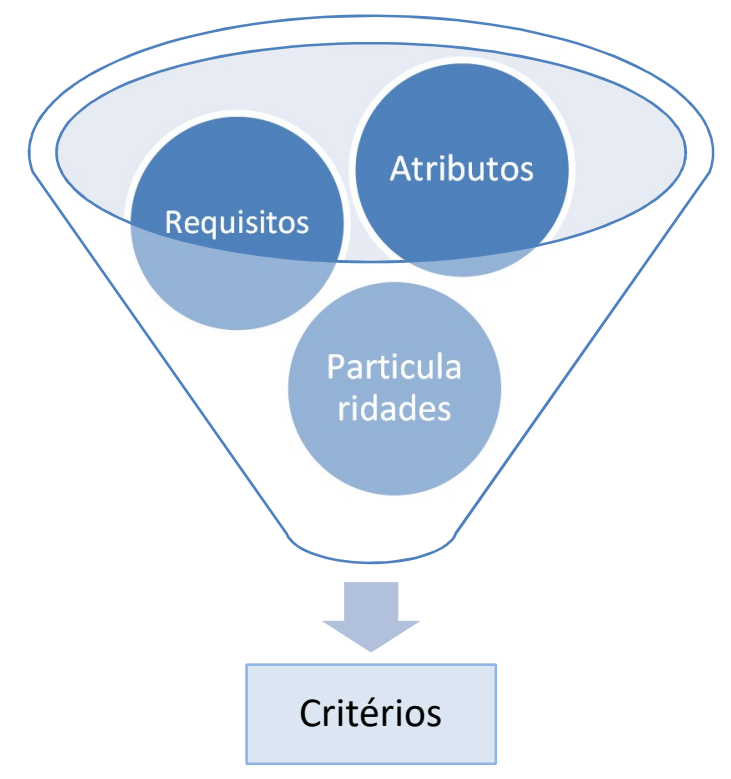

Figura 14 - Raciocínio Ferramenta de Pesquisa 
A ferramenta leva em consideração as fases preliminar e interna do processo licitatório. A primeira fase é responsável pelo planejamento preliminar do objeto e pela definição propriamente dita dos critérios e diretrizes que nortearão a escolha do contratado e a elaboração dos projetos. A segunda corresponde às determinações operacionais e formais do processo de licitação, a exemplo da escolha das modalidades e tipos de licitação.

A ferramenta está dividida em duas partes distintas. A primeira corresponde aos quesitos meramente instrumentais, cuja função é identificar e caracterizar o objeto de estudo. A primeira parte está composta por campos de preenchimento levantando: i) a entidade Contratante e a sua localidade; ii) a tipologia funcional do objeto contratado (atividade a que se destina a obra); iii) o tipo de obra (edificação ou infraestrutura. Esta pesquisa considera somente licitações relativas ao primeiro caso), o ano da contratação e os instrumentos de licitação analisados - correspondentes a editais, termos de referência, projetos básicos e especificações técnicas; conforme indicado na Tabela 01 .

\begin{tabular}{|c|c|c|c|c|}
\hline \multicolumn{5}{|c|}{ Informações Gerais } \\
\hline $\begin{array}{c}\text { Contratante (Órgão) / } \\
\text { Localidade }\end{array}$ & $\begin{array}{c}\text { Tipologia Funcional } \\
\text { (Objeto) }\end{array}$ & Edificação / Infraestrutura & $\begin{array}{c}\text { Ano } \\
\text { Contratação }\end{array}$ & Documento Analisado \\
\hline Entidade & $\begin{array}{c}\text { Administrativo / } \\
\text { Educacional }\end{array}$ & Edificação & $2010-2016$ & Edital / TR / PB / EP \\
\hline
\end{tabular}

Tabela 1. Ferramenta Pesquisa Parte 01

A segunda parte da ferramenta corresponde ao objeto de pesquisa propriamente dito. Ela é constituída por 06 (seis) colunas - referentes à fase de licitação, à etapa dentro do processo licitatório (que indica a atividade principal da fase correspondente), a categoria em que os critérios estão classificados, a subcategoria (correspondente aos critérios propriamente ditos), a avaliação (subdividida em duas colunas indicando a presença em caso de resposta positiva e ausência quando negativa) e, finalmente, uma coluna destinada a observações (utilizada, sobretudo, para indicar os itens dos instrumentos licitatórios que correspondem aos critérios avaliados).

\begin{tabular}{|c|c|c|c|c|c|c|}
\hline \multicolumn{7}{|c|}{ Mapeamento Processos } \\
\hline \multirow{2}{*}{ FASE } & \multirow{2}{*}{ ETAPA } & \multirow{2}{*}{ CATEGORIA } & SUB-CATEGORIA & Ava & ação & \multirow{2}{*}{ Observações } \\
\hline & & & Critérios de Avaliação & Sim & Não & \\
\hline
\end{tabular}

Tabela 2. Ferramenta Pesquisa - Estrutura Parte 02

Devido ao foco da pesquisa residir na fase preliminar do processo licitatório, somente as subcategorias dessa fase serão avaliadas de forma quantitativas a fim de produzir resultados, uma vez que correspondem aos critérios de avaliação e diretrizes de projeto dos instrumentos de licitação que é objeto da pesquisa. 
Como a fase interna de licitação indica os aspectos funcionais e formais do processo licitatório, serve como meio de classificação dos instrumentos analisados conforme a modalidade, indicando também o nível de detalhamento do projeto (que mostra quais etapas de projetos serão contempladas pela contratação - do estudo preliminar ao projeto executivo), a forma de contratação das demais especialidades em relação ao projeto arquitetônico e a forma de compartilhamento de informações, caso existente.

\subsubsection{Categorias da Fase Preliminar}

A etapa de Concepção do Produto (Coluna 02), dentro da fase Preliminar (Coluna 01), é constituída por 03 (três) categorias - Avaliação de Aspectos Técnicos, Avaliação de Aspectos Ambientais e Avaliação de Aspectos Socioeconômicos - responsáveis por classificar os critérios de avaliação.

A classificação dos critérios conforme as categorias citadas atendem à observação feita por TCU (2013) de que os estudos de viabilidade, presente na fase preliminar, tem por objetivo eleger a solução que melhor responda ao programa de necessidades sob os aspectos técnico, ambiental e socioeconômico.

\subsubsection{Avaliação de Aspectos Técnicos}

Em relação à Avaliação de Aspectos Técnicos, os critérios de avaliação estão relacionados às questões que tenham influência direta na forma de execução da obra, nas características funcionais e estruturais e na operação da edificação a ser planejada. A tabela 03 sintetiza os atributos e requisitos que formaram os critérios da corrente categoria, que são conceituados e analisados a seguir: 


\begin{tabular}{|c|c|c|}
\hline \multicolumn{3}{|c|}{ FERRAMENTA 01 - RACIOCÍNIO } \\
\hline Categoria & Critérios Avaliação & Atributos / Requisitos SCI \\
\hline \multirow{32}{*}{ Aspectos Técnicos } & Prazo Execução & Menor Tempo de Execução \\
\hline & \multirow{5}{*}{ Produtividade } & Facilidade de Montagem \\
\hline & & Menor Tempo de Execução \\
\hline & & Menor Desperdício \\
\hline & & Modulação \\
\hline & & Projeto com Visão Montagem \\
\hline & \multirow{6}{*}{ Qualidade } & Pré-fabricação \\
\hline & & Padronização Componentes \\
\hline & & Menor Rigor Dimensional \\
\hline & & Alto Nível de Precisão \\
\hline & & Soluções Racionalizadas \\
\hline & & Modulação \\
\hline & \multirow{5}{*}{ Flexibilidade } & Menor Peso Próprio / Leveza \\
\hline & & Grandes Vãos \\
\hline & & Construção a Seco \\
\hline & & Diversidade e Flexibilidade de Composições \\
\hline & & Facilidade Montagem \\
\hline & \multirow{2}{*}{ Expansibilidade / Adaptabilidade } & Diversidade e Flexibilidade de Composições \\
\hline & & Facilidade de Montagem \\
\hline & \multirow{5}{*}{ Interface entre sistemas } & Alto Grau Delhamento (Ligações / Interface) \\
\hline & & Projeto com Visão Montagem \\
\hline & & Compatibilização \\
\hline & & Soluções Racionalizadas \\
\hline & & Modulação \\
\hline & \multirow{5}{*}{ Desmontagem / Remontagem } & Facilidade Montagem \\
\hline & & Diversidade e Flexibilidade de Composições \\
\hline & & Construção a Seco \\
\hline & & Desmontagem e Reaproveitamento \\
\hline & & Menor Peso Próprio / Leveza \\
\hline & Sistema Construt. Industrializado & - \\
\hline & Sistema Construtivo Racionalizado & - \\
\hline & $\begin{array}{l}\text { Disponibilidade Local dos Sistemas } \\
\text { Construtivos }\end{array}$ & - \\
\hline
\end{tabular}

Tabela 3 - Formação critérios da Categoria Aspectos Técnicos.

\section{a) Prazo de Execução do empreendimento}

Seguindo o raciocínio de construção dos critérios de avaliação da ferramenta referente à fase preliminar da obra pública a partir dos atributos e requisitos dos principais sistemas construtivos industrializados utilizados no Brasil, conforme exposto no capítulo 03; identificou-se que entre os atributos desses sistemas construtivos está a redução do tempo de execução da obra, haja visto a transferência de parte considerável das atividades de transformação e agregação de valor para o ambiente fabril.

Destaca-se ainda que outros atributos e requisitos de projeto dos sistemas construtivos industrializados são de grande importância para a redução do prazo de execução da obra, tais como a facilidade de montagem, a padronização dos componentes, a racionalização e modulação das soluções de projeto e a elaboração do projeto com visão de montagem e de logística. 
Dessa forma, o presente critério corresponde ao intervalo de tempo total utilizado na materialização do empreendimento, abrangendo o prazo de elaboração dos projetos e o prazo de execução das obras, sendo considerado por esse trabalho quando incorrer em uma premissa de projeto claramente expressa nos instrumentos licitatórios.

b) Produtividade

$\mathrm{O}$ critério referente à produtividade parte da identificação dos seguintes atributos identificados nos sistemas construtivos industrializados: a facilidade de montagem, o menor tempo de execução e menor desperdício de insumos; bem como dos requisitos de projeto referentes à necessidade de modulação e racionalização das soluções e da elaboração dos projetos com visão de montagem e do planejamento da logística.

Segundo MATOS (2006), "a produtividade é a quantidade de unidades de trabalho produzida em um intervalo de tempo especificado, normalmente hora. A produtividade indica a eficiência em transformar energia (e tempo) em um produto". A partir da definição apresentada, observa-se uma estreita relação entre a questão da produtividade e do prazo de execução da obra, sendo eles inversamente proporcionais entre si.

Diante do exposto, o presente trabalho considera a produtividade como a relação entre resultado, produto pronto e esforço, insumos e tempo. A pesquisa também busca identificar nos documentos analisados a solicitação expressa da produtividade como premissa de projeto.

\section{c) Qualidade de acabamento}

Rocha Lima Jr. (1995) considera a ideia de qualidade como um referencial de caráter abstrato, estando ele relacionado à expectativa que os usuários dos sistemas terão quanto ao seu desempenho, sendo esta, portanto, uma conceituação ampla. Já a presente pesquisa recorta o conceito de qualidade aplicado à regularidade, precisão e nível de acabamento dos sistemas construtivos.

Tal recorte parte da identificação dos seguintes atributos dos sistemas construtivos industrializados apresentados no capítulo 03: o modo de produção pré-fabricado, que por si já pressupõe maior nível de acabamento e regularidade; a padronização dos componentes, decorrente do processo fabril; o maior rigor dimensional identificado tanto na produção dos componentes quanto na montagem dos mesmos em obra. Esse conceito também parte dos seguintes requisitos de projetos dos SCI: Alto nível de precisão e acurácia dimensional dos projetos, soluções racionalizadas e a modulação.

A corrente pesquisa considera a qualidade como a exigência expressa nos instrumentos licitatórios por parte da entidade contratante quanto ao nível de acabamento, 
regularidade e precisão das soluções projetuais e, consequentemente da obra a ser executada posteriormente.

\section{d) Flexibilidade}

O conceito de flexibilidade, a partir da compreensão da obra de Ribeiro (2002), apresenta dois significados. $\mathrm{O}$ primeiro relacionado à construtibilidade, que no presente trabalho relaciona-se a dois critérios - a expansibilidade ou adaptabilidade e a interface entre os sistemas utilizados na edificação. O segundo relaciona-se a ao uso, permitindo a variação ou modificação das configurações internas da edificação com certa facilidade.

Neste trabalho considera-se como critério de avaliação da ferramenta o conceito de flexibilidade relacionado ao uso da edificação; estando esse critério vinculado aos seguintes atributos dos sistemas construtivos industrializados: menor peso próprio e maior leveza; possibilidade de grandes vãos nos sistemas estruturais em aço e concreto pré-fabricado; a construção a seco; a diversidade e flexibilidade de composições e a facilidade de montagem, principalmente dos sistemas panelisados e em malhas - tais como wood frame, steelframe e drywall.

\section{e) Expansibilidade ou Adaptabilidade}

A expansibilidade ou adaptabilidade decorre da flexibilidade construtiva e consiste na facilidade de modificar a edificação com ganho ou supressão de área construída a fim de atender a uma nova exigência no programa de necessidades com o mínimo de conflito com a sua operação e funcionamento.

$\mathrm{O}$ critério referente à expansibilidade ou adaptabilidade está associado principalmente aos atributos dos sistemas construtivos industrializados relacionados à diversidade e flexibilidade de composições e a facilidade de montagem; e a ferramenta de pesquisa considera esse critério diante da requisição expressa por parte da entidade contratante quanto à possibilidade de modificar a edificação em sua área construída, seja por adição ou por supressão.

\section{f) Interface entre os sistemas}

Também decorrente do conceito primário de flexibilidade construtiva, o critério relacionado à interface entre os sistemas construtivos versa sobre a facilidade de integração, combinação e melhor coordenação entre os componentes do mesmo sistema ou de sistemas diferentes a fim de evitar diversos problemas, tais como desperdícios de insumos e retrabalhos.

Compreende-se de Ribeiro (2002) que o referido critério está relacionado principalmente aos sistemas industrializados abertos, apontados pelo autor como 
tendência natural no processo de industrialização da construção com a finalidade de introduzir elementos construtivos de série, como componentes acopláveis e combináveis, e de propor uma metodologia de projeto sobre uma correta aplicação desses componentes.

O raciocínio de construção e justificativa do critério referente à interface entre os sistemas parte da identificação dos seguintes requisitos de projeto dos sistemas construtivos industrializados: Necessidade de alto grau de detalhamento das ligações e interfaces entre os sistemas, projeto com visão de montagem, compatibilização detalhada entre as diversas especialidades, soluções racionalizadas e a coordenação modular.

Dessa forma, o presente critério é considerado por este trabalho como uma clara indicação nos instrumentos de licitação da necessidade de resolução da problemática referente à interface entre os diferentes sistemas construtivos e seus componentes por parte das soluções de projeto.

\section{g) Possibilidade de desmontagem e remontagem}

A ideia da possibilidade desmontagem e remontagem advém do conceito de Design for Deconstruction apresentado por Addis e Schounten (2004), que corresponde à possibilidade de desconstrução ou desmontagem da edificação, inteira ou de sistemas construtivos referentes à estrutura, cobertura ou vedação, de maneira facilitada e que permita uma nova montagem ou nova utilização dos sistemas ou de seus componentes.

O presente critério é considerado como uma determinação expressa no instrumento licitatório quanto à possibilidade e capacidade de desmontagem e remontagem dos sistemas construtivos e está relacionado aos atributos dos sistemas construtivos industrializados referentes ao menor peso próprio; à facilidade de montagem; à capacidade de desmonte dos sistemas preservando sua topologia bem as suas propriedades físicas e químicas, o que permite seu reaproveitamento; à diversidade e flexibilidade de composições e a construção à seco.

\section{h) Sistema Construtivo Industrializado}

Conforme abordado no item 3.3.1 do capítulo 03, o conceito de sistema construtivo industrializado equivale à "associação de componentes produzidos a partir de materiais diversos em ambiente industrial, a partir de processos mecanizados, dotados de maior rigor técnico e superiores requisitos de regularidade e qualidade, e posteriormente transportados e montados no canteiro de obra com a utilização de equipamentos com maior ou menor grau de especificidade " (BRASIL, 1995).

Diferentemente dos critérios anteriores, que partem dos atributos e requisitos dos sistemas construtivos industrializados, o presente critério consiste na expressa 
determinação da preferência pela utilização de sistemas construtivos industrializados como solução de projeto por parte da contratante, configurando uma clara diretriz para a industrialização do processo construtivo da edificação objeto da contratação.

i) Sistema Construtivo Racionalizado

Conforme ABDI (2015), os sistemas construtivos racionalizados consistem naqueles produzidos de forma racionalizada, embora não sejam fabricados em ambiente industrial, uma vez que sua produção e montagem são realizadas no próprio canteiro. Esses sistemas são caracterizados pela racionalização e modularização, embora não apresentem o mesmo rigor em termos dimensionais e de regularidade próprios do ambiente fabril.

Por ser considerado um passo importante para racionalização e um caminho para industrialização (ABDI, 2015), o presente critério também parte da requisição expressa da preferência pela utilização de sistemas construtivos racionalizados como solução de projeto pela contratante.

j) Operação Eficiente do Empreendimento

A NBR 15.575/2013, conhecida como a Norma de Desempenho, conceitua "operação" como conjunto de atividades a serem realizadas nos diversos sistemas e equipamentos empregados em uma edificação a fim de mantê-la em funcionamento adequado.

Esta pesquisa considera o presente critério como a solicitação do ente contratante que as especificações de materiais, componentes e sistemas construtivos nas soluções de projeto tenham em vista a operação eficiente dos subsistemas contemplados pela pesquisa na edificação objeto da contratação, no caso, estruturas, vedações, divisórias e coberturas.

k) Manutenção

O conceito de manutenção, conforme a NBR 15.575/2013, corresponde ao "conjunto de atividades a serem realizadas ao longo da vida total da edificação para conservar ou recuperar a sua capacidade funcional e de seus sistemas constituintes de atender as necessidades e segurança dos seus usuários".

Observa-se que, enquanto a operação da edificação está relacionada à sua utilização e funcionamento regular, a manutenção trata da conservação ou recuperação de uma situação dos sistemas e de seus componentes que permita a continuidade do funcionamento adequado da edificação. 
Dessa forma, o trabalho avalia o presente critério a partir da solicitação no instrumento licitatório quanto a utilização do conceito de manutenção como premissa, geral ou específica, para as soluções projetuais.

1) Disponibilidade local dos sistemas construtivos

A lei 8.666/93, em seu artigo 12, ao dispor sobre os requisitos a serem considerados na elaboração dos projetos básico e executivo, considera a possibilidade de emprego de mão-de-obra, materiais, tecnologia e matérias-primas locais para execução, conservação e operação do empreendimento. Essa premissa indica uma preferência pela disponibilidade local dos sistemas construtivos adotados como solução de projeto para a obra pública a ser contratada.

A justificativa para o requisito referente à disponibilidade local dos sistemas está relacionada a uma visão ampla de sustentabilidade - que abrange a questão do custo, tempo e impactos ambientais do transporte, bem como dos impactos sociais da localidade da obra - e à questão do desenvolvimento regional, um dos objetivos da licitação.

Uma análise do presente critério, conforme exposto acima, indica que o mesmo pode agir como um entrave à industrialização da construção. Considerando a concentração na produção de sistemas construtivos industrializados em poucas localidades no atual cenário produtivo nacional, o critério deve ser avaliado de maneira inversa, isto é, quanto maior sua contabilização (ou presença) em instrumentos licitatórios, pior será o resultado.

No entanto, uma reflexão mais abrangente do mesmo critério também pode ser vista como uma oportunidade de disseminação de soluções e técnicas inovadoras e vetor de democratização de técnicas e sistemas industrializados de construção através da indução da oferta de novos polos de produção através da demanda específica do Estado, ainda que no cenário atual, e para a pesquisa, ainda seja visto como um entrave.

\subsubsection{Avaliação de Aspectos Ambientais}

Em relação à categoria Avaliação de Aspectos Ambientais, a determinação dos critérios é feita sobre o prisma dos efeitos que a edificação impõe ao meio ambiente e aos seus ocupantes ao longo de todo o seu ciclo de vida, do projeto à desconstrução ou reciclagem, passando pela extração de materiais, produção de insumos, execução da obra e pelo seu funcionamento. 
A Tabela 04 mostra a síntese da relação entre os atributos e requisitos dos sistemas construtivos industrializados e os critérios correspondentes à essa categoria, que serão conceituados e analisados em seguida.

\begin{tabular}{|c|l|l|}
\hline \multicolumn{2}{|c|}{ FERRAMENTA 01 - RACIOCíNIO } \\
\hline Categoria & \multicolumn{1}{|c|}{ Critérios Avaliação } & \multicolumn{1}{c|}{ Atributos / Requisitos SCI } \\
\hline \multirow{3}{*}{ Aspectos Ambientais } & ACV & Durabilidade \\
\cline { 2 - 3 } & $\begin{array}{l}\text { Utilização de Materiais e } \\
\text { Componentes Reutilizáveis }\end{array}$ & $\begin{array}{l}\text { Desmontagem e Reaproveitamento } \\
\text { Cilização de Materiais e }\end{array}$ \\
\cline { 2 - 3 } & $\begin{array}{l}\text { Componentes Reciclados } \\
\text { Cilização de Materiais e }\end{array}$ & \\
\hline & Componentes Recicláveis & Reclabilidade \\
\hline
\end{tabular}

Tabela 4 - Formação critérios da Categoria Aspectos Ambientais

a) Avaliação de Ciclo de Vida (ACV)

Conforme a ABNT (2014), a Avaliação de Ciclo de Vida consiste na compilação e avaliação das entradas e saídas de aspectos ambientais e impactos ambientais potenciais ao longo do ciclo de vida do produto. Para Soares, Souza e Pereira (2006), o princípio da $\mathrm{ACV}$ "consiste em analisar as repercussões ambientais de um produto ou atividade, a partir de um inventário de entradas e saídas (matérias-primas e energia, produto, subprodutos e resíduos) do sistema considerado".

Segundo Filha et al. (2010), ao tratar sobre habitação, o ciclo de vida pode ser dividido em quatro partes: concepção e aprovação do projeto, produção da construção, uso; e reforma ou demolição. Destaca também a necessidade de implantação de uma visão sistêmica quanto ao ciclo de vida dos empreendimentos da construção industrializada.

Quando analisado frente aos atributos dos sistemas construtivos industrializados, observa-se uma relação entre a ACV com a durabilidade desses sistemas e com a possibilidade de desmontagem e reutilização e a propriedade de reciclagem presente na maioria deles, a exemplo do steel frame e das estruturas em aço.

Diante da importância do tema e das vantagens dos sistemas construtivos industrializados quanto a $\mathrm{ACV}$, o presente critério busca identificar a solicitação do contratante nos instrumentos de licitação quanto a utilização da ACV como premissa de projeto.

\section{b) Utilização de materiais e componentes reutilizáveis}

A utilização de materiais e componentes reutilizáveis possui estreita relação com os critérios referentes à expansibilidade e adaptabilidade da edificação e à desmontagem 
e remontagem ao se referir à possibilidade de empregar sistemas e componentes que possam manter suas características, suas propriedades técnicas e suas funções após o fim do ciclo de vida da edificação na qual foram primeiramente utilizados, havendo a possibilidade de nova utilização sem a necessidade de maiores reparos, porém sob o enfoque da redução de impactos ambientais que o critério permite.

c) Utilização de materiais e componentes reciclados

O presente critério consiste na exigência ou sugestão por parte da contratante, pela especificação e utilização de sistemas, componentes ou materiais oriundos de processos de reciclagem no projeto e na obra, respectivamente, estando relacionado à propriedade da reciclabilidade dos materiais utilizados nos sistemas construtivos industrializados.

d) Utilização de materiais e componentes recicláveis

Semelhante ao item anterior, o critério em questão está relacionado a exigência ou sugestão nos instrumentos licitatórios pela especificação e utilização de sistemas, componentes ou materiais passíveis de serem reutilizados mediante processo de reciclagem, transformando-os em componentes ou materiais iguais aos anteriores à reciclagem ou diferentes.

e) Certificação de origem dos materiais e componentes

O presente critério está relacionado ao conceito de "Compra Responsável”, cuja definição, segundo Ferrari et al. (2015) consiste na "integração entre estratégias organizacionais e práticas de aquisição de materiais, que se baseia na responsabilidade ambiental, econômica e social e tem como objetivo promover uma nova forma de atuação das empresas, assumindo o compromisso como instituição responsável na especificação e aquisição de produtos e serviços".

Ainda conforme as palavras de Ferrari et al. (2015), a ideia de "Compra Responsável" reside na premissa de que as diversas iniciativas durante o processo construtivo com vistas à sustentabilidade são inócuas caso não seja possível garantir a origem social e ambientalmente responsáveis dos materiais e serviços, uma vez que a organização passa a ter responsabilidade solidária pelos passivos legais, ambientais ou sociais de seus fornecedores.

Ao considerar que o conceito de construção industrializada está, em parte, atrelado à transferência dos processos de transformação e agregação de valor para a cadeia de suprimentos, é possível admitir que a adoção de sistemas construtivos industrializados facilita o processo de certificação de origem. 
Tal fato pode ser justificado pela capacidade da cadeia de suprimentos em concentrar a relação com os diversos fornecedores, o que permite maior facilidade de rastreamento das condições socioambientais da origem dos diversos materiais e componentes,

Sendo assim, o presente critério visa identificar se a entidade pública contratante teve a devida preocupação com a origem dos materiais, componentes e sistemas especificados para a edificação que será materializada para atender às suas necessidades através da disposição expressa nos instrumentos licitatórios de requisitos projetuais que versem sobre a certificação de origem.

\section{f) Gestão de Resíduos}

Blumenschein (2004) aponta uma ocorrência de impactos no meio ambiente por parte da CPIC ao longo da cadeia, por meio da exploração e utilização de recursos naturais, do consumo de energia e da geração de resíduos, além dos desperdícios de matérias-primas, sendo que os dois últimos estão intimamente ligados, uma vez que o desperdício potencializa a geração de resíduos.

A autora ainda destaca a relevância da geração de resíduos do processo construtivo, cadeia principal, no meio urbano, seja pelo índice de participação na composição do resíduo urbano (entre 40\% e 70\%), seja pelos índices de disposição irregular desses resíduos no meio ambiente (em torno de 50\%).

Blumenschein (2004) também destaca a omissão das especificações e soluções de projeto para as questões relacionadas à geração de resíduos, tais como a inadequação de materiais quanto ao meio ambiente e a falta de otimização, padronização e modulação nas soluções técnicas.

Ao observar as possíveis causas para o agravamento da geração de resíduos apontada por Blumenschein (2004), é possível perceber um alinhamento de alguns atributos e requisitos de projetos dos sistemas construtivos como forma de mitigação desses impactos, a exemplo da pré-fabricação - que transfere a produção para o ambiente fabril controlado, reciclabilidade e reaproveitamento, necessidade de soluções racionalizadas e modulação; o que aponta maior adequação dos sistemas construtivos industrializados à gestão de resíduos mais eficiente.

Dessa forma, a pesquisa considera o presente critério como uma requisição do instrumento licitatório quanto à necessidade de soluções ou decisões de projeto que contemplem a gestão dos resíduos sólidos gerados pela obra, a exemplo da indicação de soluções que evitem ou diminuam a produção de resíduos ou que mitiguem seus efeitos. 


\subsubsection{Avaliação de Aspectos Socioeconômicos}

A Avaliação de Aspectos Socioeconômicos trata dos critérios relacionados às premissas econômicas, financeiras e sociais que as decisões quanto à escolha dos sistemas construtivos implicam. Essas premissas possuem relação direta com o custo total da edificação, entendido aqui como o resultado da adição do custo da construção e do custo de ciclo de vida - que abrange o custo de operação e demolição da edificação.

Outro ponto considerado pelas premissas diz respeito às implicações sociais quanto a escolha dos sistemas construtivos, principalmente em relação ao direcionamento do tipo de mão-de-obra a ser utilizada e quais tipos de empregos serão gerados pela obra. Dessa forma, seguem abaixo os critérios avaliados e seus respectivos conceitos:

\begin{tabular}{|c|c|c|}
\hline \multicolumn{3}{|c|}{ FERRAMENTA 01 - RACIOCÍNIO } \\
\hline Categoria & Critérios Avaliação & Atributos / Requisitos SCI \\
\hline \multirow{7}{*}{ Aspectos Socioeconômicos } & \multirow{3}{*}{ Custo Construção (Economicidade) } & Facilidade de Montagem \\
\hline & & Menor Tempo de Execução \\
\hline & & Menor Desperdício \\
\hline & Custo Ciclo de Vida & Durabilidade \\
\hline & Utilização Mão-de-obra Local & - \\
\hline & \multirow{2}{*}{$\begin{array}{l}\text { Utilização Mão-de-obra } \\
\text { Especializada }\end{array}$} & $\begin{array}{l}\text { Utilização Equipamentos Específicos na } \\
\text { montagem }\end{array}$ \\
\hline & & Necessidade de mão-de-obra especializada \\
\hline
\end{tabular}

Tabela 5 - Formação critérios da Categoria Aspectos Socioeconômicos

\section{a) Custo da Construção (Economicidade)}

Sendo a escassez de recursos financeiros uma característica recorrente da administração pública, principalmente quanto a investimentos, a preocupação com o custo do empreendimento pode ser considerada como fator de decisão, ainda que tacitamente, em qualquer processo de planejamento de obra pública.

Conforme Cardozo (1999), o conceito de custo pode ser dividido em custos diretos, referentes aos insumos necessários à execução da obra (materiais, mão-de-obra e equipamentos), e custos indiretos, considerados como os demais custos que incidem de forma coletiva sobre a obra, embora não estejam relacionados à produção diretamente, a exemplo dos custos com impostos, seguros e custos financeiros.

Uma análise comparativa restrita ao custo direto entre os sistemas tradicionais e os industrializados tendem a apontar melhores resultados para o primeiro, uma vez que os valores referentes à agregação de valor são realizados dentro canteiro de obra quando se opta pela utilização de sistemas tradicionais e os lucros advindos da produção ficam com a empresa responsável pela execução da obra. 
Entretanto, ao se analisar o fator custo considerando o impacto na produtividade e na redução do prazo de execução bem como nos custos indiretos é possível observar um ajuste nos valores, dado o impacto positivo da utilização de sistemas construtivos industrializados nos custos indiretos

Um exemplo dos custos indiretos tratados acima é o custo financeiro, que, segundo Matos (2006), se refere à defasagem do dinheiro aplicado na obra ou tarefa em comparação com os ganhos de uma aplicação financeira em período equivalente à execução dessas.

Esses impactos positivos podem ser observados principalmente quanto aos ganhos de produtividade e a consequente redução no prazo de execução da obra. Outro aspecto relacionado ao custo está na antecipação do retorno de investimento na obra, sendo que enquanto nas obras de iniciativa privada, a exemplo do mercado imobiliário, se tratam de retornos financeiros, as obras públicas refletem em ganhos sociais através do atendimento às necessidades da sociedade em relação à função que a obra deve desempenhar.

As situações que, devido a determinadas particularidades - tais como fonte de financiamento e necessidade de retorno econômico e social do investimento - e características do próprio empreendimento, a questão do custo se torna ainda mais relevante, a ponto de se tornar uma premissa de projeto. Dessa forma a pesquisa considera o presente critério como uma solicitação do contratante para que a proposta tome os custos de execução da obra como diretriz de projeto.

b) Custo de Ciclo de Vida

Sendo um conceito mais abrangente que o custo da construção, restrito ao planejamento e execução das obras, o Custo de Ciclo de Vida adiciona ao valor do empreendimento as cifras despendidas ao longo de todo o período de operação da edificação e da sua desconstrução - após seu período de efetivo funcionamento.

Segundo Fuller (2010), a análise do custo de ciclo de vida deve ser feita no início do processo de projeto, enquanto é possível fazer alterações nas soluções técnicas com menor custo e que garantam melhores resultados quanto à redução no custo do ciclo de vida. Daí a importância da presença desse critério na fase preliminar.

De forma semelhante ao critério referente à $\mathrm{ACV}$, o Custo de Ciclo de Vida está associado à durabilidade dos sistemas construtivos industrializados, à reciclabilidade e a possibilidade de desmontagem e reutilização, embora o primeiro esteja associado aos impactos ambientais, enquanto que o presente critério trata dos impactos financeiros. 
Assim, a pesquisa busca identificar por meio do presente critério a presença nos instrumentos de licitação da solicitação por parte da entidade contratante que o Custo de Ciclo Vida da edificação seja considerado como premissa para a elaboração dos projetos.

c) Utilização de Mão de Obra Local

A preferência pela utilização de mão de obra local implica em efeitos econômicos e sociais na localidade uma vez que mantém a força produtiva local em pleno exercício e direciona o capital para economia local por meio do pagamento dessa mão de obra.

Por outro lado, a exigência ou preferência pela mão de obra local pode funcionar como um entrave à utilização de novas tecnologias construtivas, caso aquela não seja capacitada para o trabalho com a solução pretendida para obra.

Dessa forma o presente critério busca identificar a expressa solicitação ou indicação de preferência pelo emprego da mão de obra disponível na localidade onde o empreendimento será executado, devendo ser avaliado como um entrave e, portanto, contabilizado de maneira inversa.

d) Utilização de Mão de Obra especializada

A IC possui importância econômica e social ao absorver parte considerável da mão de obra nacional com baixo grau de especialização, inclusive de baixa escolaridade. Por outro lado, essa indústria pode ser considerada um vetor de melhoria da qualidade da mão de obra a partir da exigência por determinadas capacidades, provenientes da necessidade de utilizar sistemas inovadores e com maiores exigências técnicas.

O presente critério está relacionado aos requisitos dos sistemas construtivos industrializados referentes à necessidade de mão-de-obra especializada e da utilização de equipamentos específicos na montagem em obra. Dessa forma, a avaliação do presente critério busca identificar em instrumentos de licitação a abordagem da utilização de mão de obra especializada como premissa de projeto.

\subsubsection{Categorias da Fase Interna}

Ainda relacionado aos itens da ferramenta, conforme exposto anteriormente, as categorias e critérios da Fase Interna de Licitação foram considerados com a finalidade de classificação para análise das informações da fase preliminar e não de avaliação propriamente dita.

Dessa forma, a etapa de Desenvolvimento do Produto (Coluna 02, Tabela 06), dentro da fase Interna (Coluna 01, Tabela 06), é constituída por 04 (quatro) categorias Modalidade de Contratação de Projeto, Nível de detalhamento, Contratação de projeto 
quanto as especialidades técnicas e Forma de Compartilhamento de Informações - com seus respectivos critérios de classificação, expostos abaixo:

\subsubsection{Modalidade de Contração de Projeto}

A partir da análise da legislação federal sobre licitação, nota-se que a contratação de projetos técnicos, inclusive os arquitetônicos, que tenham em seu escopo a concepção do objeto ainda é mais bem definida pela lei 8.666/93, uma vez que ela é a única que trata da possibilidade de contratação do serviço de projeto envolvendo todas as etapas e apresenta os critérios de avaliação, "melhor técnica" e "técnica e preço", mais condizentes com a natureza desses serviços.

Ainda que o objeto de estudo do presente trabalho esteja restrito às situações em que a elaboração dos projetos técnicos seja feita a partir do processo contratação indireta, a ferramenta de pesquisa traz em seu conteúdo o campo para identificação de situações de elaboração direta, isto é, pelo corpo técnico da própria administração pública.

Já para os casos de contratação indireta, foco do trabalho, a ferramenta aborda as modalidades estabelecidas pela lei 8.666/93 - Convite, Tomada de Preços, Concorrência e Concurso de Projeto - com seus respectivos tipos - Melhor Técnica, Técnica e Preço e Menor Preço. Vale destacar que a modalidade concurso, segundo a lei, não possui classificação quanto ao tipo de licitação, embora seja possível identificá-la como uma modalidade que utiliza critérios eminentemente técnicos.

Devido a especificidade necessária para classificar um processo licitatório, com a indicação da modalidade e do tipo, que se refere ao critério de julgamento das propostas, os critérios da ferramenta relacionados à presente categoria estão subdivididos em até três colunas, que indicam os tipos presentes na legislação, a fim de que se indique corretamente a classificação do processo licitatório analisado, conforme a Tabela 06.

\begin{tabular}{|c|c|c|c|c|c|c|c|c|}
\hline \multicolumn{9}{|c|}{ Mapeamento Processos } \\
\hline \multirow{2}{*}{ FASE } & \multirow{2}{*}{ ETAPA } & \multirow{2}{*}{ CATEGORIA } & \multirow{2}{*}{\multicolumn{3}{|c|}{$\begin{array}{l}\text { SUB-CATEGORIA } \\
\text { Critérios de Avaliação }\end{array}$}} & \multicolumn{2}{|c|}{ Avaliação } & \multirow{2}{*}{ Observações } \\
\hline & & & & & & Sim & Não & \\
\hline \multirow{10}{*}{ Interna } & \multirow{10}{*}{$\begin{array}{c}\text { Desenvolvimento } \\
\text { do Produto } \\
\text { (Projeto) }\end{array}$} & \multirow{10}{*}{$\begin{array}{c}\text { Modalidade de } \\
\text { Contratação de } \\
\text { Projeto }\end{array}$} & Direta & Interna & & & & \\
\hline & & & \multirow{9}{*}{ Indireta } & \multirow{2}{*}{ Convite } & Técnica & & & \\
\hline & & & & & Técnica e Preço & & & \\
\hline & & & & \multirow{3}{*}{$\begin{array}{l}\text { Tomada de } \\
\text { Preço }\end{array}$} & Menor Preço & & & \\
\hline & & & & & \begin{tabular}{|l|} 
Técnica \\
\end{tabular} & & & \\
\hline & & & & & Técnica e Preço & & & \\
\hline & & & & \multirow{3}{*}{ Concorrência } & Menor Preço & & & \\
\hline & & & & & Técnica & & & \\
\hline & & & & & Técnica e Preço & & & \\
\hline & & & & \multicolumn{2}{|c|}{ Concurso } & & & \\
\hline
\end{tabular}

Tabela 6. Categoria Modalidade de Contratação. 


\subsubsection{Nível de detalhamento do Projeto (Etapas de Projeto)}

Essa categoria de análise diz respeito ao nível de detalhamento dos projetos exigido pela contratante, que por sua vez está relacionado às normas ABNT NBR 16.636-1/2017 e ABNT NBR 16.636-2/2017 - referentes à elaboração e desenvolvimento de projetos arquitetônicos e urbanísticos. As referidas normas também tratam das etapas de projeto e do nível de detalhamento que cada etapa implica.

As etapas de projeto conforme as normas supracitadas seguem a seguinte ordem: levantamento, programa de necessidades, estudo de viabilidade, estudo preliminar, anteprojeto, projeto legal, projeto básico (opcional, conforme a lei 8.666/93) e projeto para execução ou projeto executivo.

Vale destacar que as três primeiras etapas geralmente são de responsabilidade da entidade contratante e devem fazer parte dos instrumentos licitatórios, por isso a ferramenta avalia como critério apenas as etapas de estudo preliminar, anteprojeto, projeto legal, projeto básico e projeto executivo.

Ainda que seja relevante a contratação dos serviços de projeto a partir da etapa de anteprojeto ou de projeto básico, quando o corpo técnico da entidade contratante elabora o estudo preliminar e concebe inicialmente a edificação, o presente trabalho focou nas situações onde o contratado é responsável pelos estudos arquitetônicos iniciais, seguindo o entendimento de que é nessa etapa onde as decisões quanto a escolha dos sistemas construtivos devem ser feitas e considerando a situação atual de deficiência de pessoal para execução dessas atividades no quadro técnico da administração pública.

\subsubsection{Compartilhamento de Informações}

A partir da compreensão de que a construção industrializada exige um processo de planejamento dotado de excelência em termos de coordenação e compatibilização dos diversos sistemas e componentes, bem como das informações técnicas relacionadas ao processo construtivo, observa-se que é de extrema importância a eficiência quanto ao gerenciamento das informações projetuais das diversas especialidades envolvidas para efetividade da industrialização da construção.

O sucesso do gerenciamento das informações está relacionado diretamente ao uso de estratégias e ferramentas de coordenação e compatibilização. Dentre as ferramentas utilizadas atualmente, destaca-se a plataforma BIM (Building Information Modeling), que consiste na modelagem do produto - com suas características reais - em ambiente virtual através da parametrização dos elementos especificados (DURANTE, 2013). 
A fim de avaliar o alinhamento do processo de projeto exigido pelo instrumento licitatório com o processo de projeto considerado ideal para o processo construtivo industrializado, a ferramenta busca identificar dentro dos documentos analisados diretrizes quanto ao uso da Plataforma BIM ou outra estratégia de gerenciamento de informações como requisito para a contratação ou diretriz de trabalho, destinando um critério para cada uma dessas situações, conforme exposto na tabela 07.

\begin{tabular}{|c|c|c|c|c|c|c|}
\hline \multicolumn{7}{|c|}{ Mapeamento Processos } \\
\hline \multirow{2}{*}{ FASE } & \multirow{2}{*}{ ETAPA } & \multirow{2}{*}{ CATEGORIA } & SUB-CATEGORIA & \multicolumn{2}{|c|}{ Avaliação } & \multirow{2}{*}{ Observações } \\
\hline & & & Critérios de Avaliação & Sim & Não & \\
\hline \multirow[b]{2}{*}{ Interna } & \multirow{2}{*}{$\begin{array}{c}\text { Desenvolvimento } \\
\text { do Produto } \\
\text { (Projeto) }\end{array}$} & \multirow{2}{*}{$\begin{array}{l}\text { Compartilhamento } \\
\text { de informações }\end{array}$} & Utilização da Plataforma BIM como requisito & & & \\
\hline & & & $\begin{array}{l}\text { Utilização de Ferramenta, Plataforma ou } \\
\text { Estratégia de compartilhamento de informações }\end{array}$ & & & \\
\hline
\end{tabular}

Tabela 7 - Categorias referentes ao compartilhamento de informações.

\subsubsection{Do preenchimento da ferramenta}

Tendo em vista a objetividade no preenchimento da ferramenta e na obtenção dos resultados, os instrumentos de licitação são analisados conforme os critérios estabelecidos nos itens anteriores; e estes casos sejam identificados dentro de qualquer instrumento do processo licitatório em questão, a sua presença deverá ser assinalada no campo “Avaliação" na coluna "Sim”. Caso contrário, a ausência do critério deverá ser assinalada no campo "Avaliação" na coluna "Não", conforme indicado.

Após o preenchimento da primeira parte da ferramenta, que indica as informações iniciais do processo licitatório analisado, é recomendado que o preenchimento da ferramenta seja iniciado pelos campos referentes às modalidades de licitação e seus respectivos tipos, a fim de classificar o processo licitatório analisado.

O segundo passo para o preenchimento da ferramenta é a indicação de quais etapas de projeto e quais especialidades técnicas estão contempladas na contratação analisada, ainda com a finalidade de classificar o processo de licitação em análise, para que só então sejam avaliados os demais critérios da fase interna de licitação e dos aspectos referentes ao modo de compartilhamento de informação.

A fim de demonstrar os resultados das análises por meio de gráficos que indiquem e comparem os níveis de ocorrência dos critérios em cada modalidade, os campos destinados às repostas positivas devem ser preenchidos com o número um, permitindo ao software utilizado na formulação da ferramenta, Microsoft Excel, sintetizar os resultados. A Tabela 08 representa a ferramenta de pesquisa com as categorias e critérios descritos. 


\begin{tabular}{|c|c|c|c|c|c|c|c|c|}
\hline \multicolumn{9}{|c|}{ Informações Gerais } \\
\hline \multicolumn{2}{|c|}{ Contratante (Órgão) / Localidade } & $\begin{array}{c}\text { Tipologia Funcional } \\
\text { (Objeto) }\end{array}$ & \multicolumn{2}{|c|}{ Edificação / Infraestrutura } & Ano Contratação & \multicolumn{3}{|c|}{ Documento Analisado } \\
\hline \multicolumn{2}{|c|}{ Entidade } & $\begin{array}{c}\text { Administrativo / } \\
\text { Educacional }\end{array}$ & \multicolumn{2}{|c|}{ Edificação } & $2010-2016$ & \multicolumn{3}{|c|}{ Edital / TR / PB / EP } \\
\hline \multicolumn{9}{|c|}{ Mapeamento Processos } \\
\hline \multirow{2}{*}{ FASE } & \multirow{2}{*}{ ETAPA } & \multirow{2}{*}{ CATEGORIA } & \multicolumn{3}{|c|}{ SUB-CATEGORIA } & \multicolumn{2}{|c|}{ Avaliação } & \multirow{2}{*}{ Observações } \\
\hline & & & \multicolumn{3}{|c|}{ Critérios de Avaliação } & Sim & Não & \\
\hline \multirow{22}{*}{$\begin{array}{c}\text { Fase } \\
\text { Preliminar }\end{array}$} & \multirow{22}{*}{$\begin{array}{l}\text { Concepção do } \\
\text { Produto }\end{array}$} & \multirow{12}{*}{$\begin{array}{c}\text { Avaliação Aspectos } \\
\text { Técnicos }\end{array}$} & \multicolumn{3}{|c|}{ Prazo de execução (Projeto + Obra) } & & & \\
\hline & & & \multicolumn{3}{|c|}{ Produtividade } & & & \\
\hline & & & \multicolumn{3}{|c|}{ Qualidade } & & & \\
\hline & & & Flexibilid & & & & & \\
\hline & & & Expansib & Adaptabilidade & & & & \\
\hline & & & Interface & s sistemas & & & & \\
\hline & & & Desmon & Nova Montagem & & & & \\
\hline & & & Sistema & ivo industrializac & & & & \\
\hline & & & Sistema & ivo racionalizad & & & & \\
\hline & & & Operaçã & te do Empreend & ento & & & \\
\hline & & & Manuter & & & & & \\
\hline & & & Disponib & ocal dos sistema & onstrutivos & & & \\
\hline & & & ACV & & & & & \\
\hline & & & Utilizaçã & teriais e compor & tes reciclados & & & \\
\hline & & Avaliação Aspectos & Utilizaçã & teriais e compor & tes recicláveis & & & \\
\hline & & Ambientais & Utilizaçã & teriais e compor & tes reutilizáveis & & & \\
\hline & & & Certifica & rigem dos mate & is e componentes & & & \\
\hline & & & Gestão c & dos & & & & \\
\hline & & & Custo de & ıção (Economici & & & & \\
\hline & & Avaliação Aspectos & Custo de & vida & & & & \\
\hline & & Socioeconômicos & Utilizaçã & o-de-obra local & & & & \\
\hline & & & Utilizaçã & o-de-obra espec & lizada & & & \\
\hline & & & Direta & Interna & & & & \\
\hline & & & & Convito & Técnica & & & \\
\hline & & & & convite & Técnica e Preço & & & \\
\hline & & & & & Menor Preço & & & \\
\hline & & Modalidade de & & lomada de & Técnica & & & \\
\hline & & Contrataçao de & Indireta & & Técnica e Preço & & & \\
\hline & & & & & Menor Preço & & & \\
\hline & & & & Concorrência & Técnica & & & \\
\hline & & & & & Técnica e Preço & & & \\
\hline & & & & & curso & & & \\
\hline & Desenvolvimento & & Estudo P & & & & & \\
\hline Interna & do Produto & & Antepro & & & & & \\
\hline & (Projeto) & Nivel de & Projeto & & & & & \\
\hline & & & Projeto & & & & & \\
\hline & & & Projeto & & & & & \\
\hline & & & Contrata & ada da especiali & de arquitetura & & & \\
\hline & & Projeto quanto as & $\begin{array}{l}\text { Contrata } \\
\text { compati }\end{array}$ & ada das especial & des + & & & \\
\hline & & & $\begin{array}{l}\text { Contrata } \\
\text { especiali }\end{array}$ & $\begin{array}{l}\text { orojetos integrac } \\
\text { ecessárias) }\end{array}$ & (todas as & & & \\
\hline & & & Utilizaçã & taforma BIM co & requisito & & & \\
\hline & & de informações & $\begin{array}{l}\text { Utilizaçã } \\
\text { de comp }\end{array}$ & $\begin{array}{l}\text { ramenta, Platafc } \\
\text { ento de informa }\end{array}$ & na ou Estratégia & & & \\
\hline
\end{tabular}

Tabela 8 - Ferramenta de pesquisa 01 .

A fim de facilitar a aferição dos resultados e a geração das informações, foram elaborados dois tipos de tabelas complementares, meramente instrumentais. A primeira trata da compilação dos resultados de cada critério por modalidade, sendo as linhas 
ocupadas pelos critérios e computação das análises de cada processo licitatório e as colunas indicam os dez processos licitatórios, conforme exposto pela tabela 09 .

\begin{tabular}{|c|c|c|c|c|c|c|c|c|c|c|c|}
\hline \multirow{2}{*}{\multicolumn{12}{|c|}{$\begin{array}{l}\text { CRITÉRIOS } \\
\text { Prazo de execução } \\
\text { (Projeto + Obra) }\end{array}$}} \\
\hline & & & & & & & & & & & \\
\hline \multicolumn{12}{|l|}{ Produtividade } \\
\hline \multicolumn{12}{|l|}{ Qualidade } \\
\hline \multicolumn{12}{|l|}{ Flexibilidade } \\
\hline \multicolumn{12}{|l|}{$\begin{array}{l}\text { Expansibilidade / } \\
\text { Adaptabilidade }\end{array}$} \\
\hline \multicolumn{12}{|l|}{$\begin{array}{l}\text { Interface entre os } \\
\text { sistemas }\end{array}$} \\
\hline \multicolumn{12}{|l|}{$\begin{array}{l}\text { Desmontagem / Nova } \\
\text { Montagem }\end{array}$} \\
\hline \multicolumn{12}{|l|}{$\begin{array}{l}\text { Sistema construtivo } \\
\text { industrializado }\end{array}$} \\
\hline \multicolumn{12}{|l|}{$\begin{array}{l}\text { Sistema construtivo } \\
\text { racionalizado }\end{array}$} \\
\hline \multicolumn{12}{|l|}{$\begin{array}{l}\text { Operação Eficiente do } \\
\text { Empreendimento }\end{array}$} \\
\hline \multicolumn{12}{|l|}{ Manutenbilidade } \\
\hline \multicolumn{12}{|l|}{$\begin{array}{l}\text { Disponibilidade local dos } \\
\text { sistemas construtivos }\end{array}$} \\
\hline \multicolumn{12}{|l|}{ ACV } \\
\hline \multicolumn{12}{|l|}{$\begin{array}{l}\text { Utilização de materiais e } \\
\text { componentes reciclados }\end{array}$} \\
\hline \multicolumn{12}{|l|}{$\begin{array}{l}\text { Utilização de materiais e } \\
\text { componentes recicláveis }\end{array}$} \\
\hline \multicolumn{12}{|c|}{$\begin{array}{l}\text { Utilização de materiais e } \\
\text { componentes reutilizáveis }\end{array}$} \\
\hline \multicolumn{12}{|l|}{$\begin{array}{l}\text { Certificação de origem } \\
\text { dos materiais e } \\
\text { componentes }\end{array}$} \\
\hline \multicolumn{12}{|l|}{ Gestão de Resíduos } \\
\hline \multicolumn{12}{|l|}{$\begin{array}{l}\text { Custo de Construção } \\
\text { (Economicidade) }\end{array}$} \\
\hline \multicolumn{12}{|l|}{ Custo de Ciclo de vida } \\
\hline \multicolumn{12}{|l|}{$\begin{array}{l}\text { Utilização de Mão-de- } \\
\text { obra local }\end{array}$} \\
\hline $\begin{array}{l}\text { Utilização de Mão-de- } \\
\text { obra especializada }\end{array}$ & & & & & & & & & & & \\
\hline
\end{tabular}

Tabela 9. Tabela complementar 01 - Resultado por modalidade.

A segunda tabela complementar (Tabela 10) está configurada de maneira semelhante à primeira (Tabela 09). Porém, as colunas relacionadas aos processos licitatórios são substituídas pelas informações com o somatório dos critérios em cada uma das quatro modalidades analisadas. Ou seja, enquanto a tabela 03 indica os resultados de processos licitatórios de uma mesma modalidade, a tabela 04 demonstra o somatório dos resultados da tabela 09 , indicando o total de cada critério por modalidade. 


\begin{tabular}{|c|c|c|c|c|c|c|}
\hline Categorias & Critério & Concorrência & $\begin{array}{l}\text { Concurso } \\
\text { de Projeto }\end{array}$ & $\begin{array}{l}\text { Tomada de } \\
\text { Preços }\end{array}$ & Convite & MÉDIA \\
\hline \multirow{12}{*}{$\begin{array}{l}\text { Avaliação } \\
\text { Aspectos } \\
\text { Técnicos }\end{array}$} & $\begin{array}{l}\text { Prazo de execução do } \\
\text { empreendimento } \\
\text { (Projeto + Obra) }\end{array}$ & & & & & \\
\hline & Produtividade & & & & & \\
\hline & Qualidade & & & & & \\
\hline & Flexibilidade & & & & & \\
\hline & $\begin{array}{l}\text { Expansibilidade / } \\
\text { Adaptabilidade }\end{array}$ & & & & & \\
\hline & $\begin{array}{l}\text { Interface entre os } \\
\text { sistemas }\end{array}$ & & & & & \\
\hline & $\begin{array}{l}\text { Desmontagem / Nova } \\
\text { Montagem }\end{array}$ & & & & & \\
\hline & $\begin{array}{l}\text { Sistema Construt. } \\
\text { Industrializado }\end{array}$ & & & & & \\
\hline & $\begin{array}{l}\text { Sistema construtivo } \\
\text { racionalizado }\end{array}$ & & & & & \\
\hline & $\begin{array}{l}\text { Operação Eficiente do } \\
\text { Empreendimento }\end{array}$ & & & & & \\
\hline & Manutenabilidade & & & & & \\
\hline & $\begin{array}{l}\text { Disponibilidade Local } \\
\text { Sist. Constr. }\end{array}$ & & & & & \\
\hline \multirow{6}{*}{$\begin{array}{l}\text { Avaliação } \\
\text { Aspectos } \\
\text { Ambientais }\end{array}$} & ACV & & & & & \\
\hline & $\begin{array}{l}\text { Utilização de materiais } \\
\text { e componentes } \\
\text { reciclados }\end{array}$ & & & & & \\
\hline & $\begin{array}{l}\text { Utilização de materiais } \\
\text { e componentes } \\
\text { recicláveis }\end{array}$ & & & & & \\
\hline & $\begin{array}{l}\text { Utilização de materiais } \\
\text { e componentes } \\
\text { reutilizáveis }\end{array}$ & & & & & \\
\hline & $\begin{array}{l}\text { Certificação de origem } \\
\text { dos materiais e } \\
\text { componentes }\end{array}$ & & & & & \\
\hline & Gestão de Resíduos & & & & & \\
\hline \multirow{4}{*}{$\begin{array}{c}\text { Avaliação } \\
\text { Aspectos } \\
\text { Socioeconômicos }\end{array}$} & $\begin{array}{l}\text { Custo de Construção } \\
\text { (Economicidade) }\end{array}$ & & & & & \\
\hline & Custo de Ciclo de vida & & & & & \\
\hline & $\begin{array}{l}\text { Utilização de Mão-de- } \\
\text { obra local }\end{array}$ & & & & & \\
\hline & $\begin{array}{l}\text { Utilização de Mão-de- } \\
\text { obra especializada }\end{array}$ & & & & & \\
\hline
\end{tabular}

Tabela 10. Tabela complementar 02 - Comparativo entre Totais das Modalidades.

Vale destacar que as tabelas complementares são utilizadas tanto para demonstrar o resultado acumulado dos critérios, sendo esse equivalente ao somatório de todas as modalidades para cada critério, quanto para demonstrar o comparativo de critério entre as quatro modalidades utilizadas, facilitando o diagnóstico pretendido. 
Os resultados obtidos pela utilização da ferramenta de pesquisa são compilados e demonstrados por meio de gráficos de barras, demonstrando a incidência e importância de cada critério nos processos licitatórios analisados.

\subsubsection{Mensuração dos Resultados.}

A avaliação dos resultados obtidos a partir da análise dos instrumentos de licitação para contratação de projetos técnicos busca identificar de maneira quantitativa a presença ou ausência de critérios referentes aos atributos e requisitos dos sistemas construtivos industrializados a fim de traçar um diagnóstico qualitativo do processo de contratação e tomada de decisão durante a fase preliminar do evento obra público.

Para tanto, essa avaliação é realizada em duas etapas, sendo a primeira referente às diferentes modalidades de licitação - Concurso, Concorrência, Tomada de Preço e Convite. A avaliação por modalidade é feita pela contabilização dos resultados por critério, somando-se cada presença dos diferentes critérios nos instrumentos de Licitação analisados.

A graduação, ou avaliação quantitativa, dos resultados toma como base a ferramenta "Phrase Completion", proposta por Hodge e Gillespie (2003) e que consiste em uma escala com onze campos de preenchimento, de 0 a 10, onde o zero corresponde à insatisfação (ou ausência) total e o dez equivale à satisfação plena, havendo ainda uma classificação dos resultados conforme a aproximação com o zero ou com o dez.

A graduação dos resultados, seguindo a lógica do "Phrase Completion", é realizada a partir da classificação do somatório de presença dos critérios no campo amostral de cada modalidade, resultado que vai de 0 a 10, sendo dividida em três estágios, de forma que o resultado de 00 a 03 é considerado ruim ou insatisfatório, de 04 a 07 é considerado um resultado regular e a presença em 08 a 10 licitações indica um bom resultado.

Uma vez que se pretende fazer um diagnóstico do processo de contratação de projetos na administração pública como um todo, a segunda avaliação dos resultados trata de um comparativo entre os resultados apresentados por cada modalidade através da aplicação de técnicas estatísticas, como a média dos resultados de cada critério e o respectivo desvio padrão, devendo o produto dessas técnicas estatísticas serem aplicados na ferramenta Phrase Completion, da mesma forma que nas análises por modalidade.

\subsection{Estudo de Caso}

Após o desenvolvimento da Ferramenta de Pesquisa, ela é aplicada em um estudo de caso correspondente à análise de instrumentos licitatórios de 40 processos de 
contratação, distribuídos igualmente entre as modalidades Concorrência Concurso, Tomada de Preços e Convite, dez de cada.

Os instrumentos analisados são os editais de licitação e os termos de referência, havendo casos em que a análise é restrita ao edital ou documentos anexos do mesmo - a exemplo de projetos básicos e especificações técnicas, visando a identificação de diretrizes de projeto que contemplem fatores determinantes para a especificação de sistemas construtivos industrializados como soluções para o objeto contratado.

São analisados processos licitatórios para a contratação de projetos para objeto certo, obra determinada, limitados a edificações novas e reformas ou modificações que envolvam aumento de área construída, descartando da pesquisa editais elaborados com foco no sistema de registro de preço para obras diversas, bem como projetos de pequenas reformas e readequação de layout.

Quanto a cronologia dos processos licitatórios analisados a pesquisa se ateve a contratações realizadas a partir de 2010, a fim retratar as necessidades e características atuais da administração pública. No que diz respeito a tipologia funcional do objeto, que indica função à qual se destina, a análise ficou restrita a edificações instituições de uso administrativo e educacional.

Já quanto às esferas administrativas e os poderes públicos não houve qualquer restrição, sendo contempladas instituições públicas nas esferas federal, estadual e municipal, além da representatividade dos três poderes e do ministério público nas amostras analisadas pela pesquisa.

Vale destacar ainda que a ideia do estudo de caso é identificar se os critérios e requisitos de projeto dos principais sistemas construtivos industrializados utilizados no país são considerados no processo de tomada de decisão por meio da sua presença nos instrumentos de licitação, principalmente nas diretrizes de projeto e/ou nos critérios de avaliação dos postulantes ao contrato.

\subsection{Proposição de Diretrizes}

Após o diagnóstico sobre a consideração dos aspectos referentes à utilização de sistemas construtivos industrializados nos instrumentos de licitação, levantado pela aplicação da ferramenta de pesquisa no estudo de caso - conforme apresentado anteriormente, a pesquisa identifica os entraves para a elaboração de instrumentos de licitação para a contratação de projetos mais alinhada ao processo de construção 
industrializada e, sobretudo, à utilização de sistemas construtivos industrializados como solução de projeto.

Diante da identificação desses entraves, são propostas diretrizes de como abordar os atributos e requisitos de projetos intrínsecos aos sistemas construtivos industrializados, bem como justificar a presença desses critérios nas diretrizes e na avaliação dos candidatos. 


\section{ESTUDO DE CASO}

O capítulo 05 apresenta o estudo de caso que consiste na avaliação de processos licitatórios para a contratação de projetos técnicos de arquitetura, de forma isolada ou com as demais especialidades, quanto a presença de diretrizes de projeto nos instrumentos licitatórios que estejam alinhadas aos atributos e especificidades dos SCI, funcionando como critérios de tomada de decisão para a escolha desses sistemas.

O presente capítulo ainda apresenta uma análise dos resultados obtidos por meio da aplicação da ferramenta de pesquisa nos instrumentos licitatórios. Essa análise é realizada por modalidade e ainda pela comparação entre essas modalidades, além de uma análise comparativa por tipo de Licitação.

\subsection{Disposições iniciais.}

Conforme exposto, ao considerar a lei 8.666/93 como a única que aborda a possibilidade de contratar todas as etapas de projeto, a pesquisa chegou ao entendimento da necessidade de restringir o campo de análise quanto às modalidades de licitação pertencentes à essa lei, avaliando apenas processos licitatórios das modalidades Concurso, Concorrência, Tomada de Preço e Convite.

A escolha das modalidades citadas acima é justificada pelo fato da legislação pertinente considerar o concurso como a modalidade ideal para contratação de serviços técnicos e a concorrência ideal para contratações de grande vulto, e pelo fato da modalidade tomada de preços ser uma forma consagrada de contratação de projetos e por não apresentar maiores restrições quanto a participação de interessados.

Embora a modalidade convite possua algumas restrições, uma vez que apresenta restrição de valor - limitada a $\mathrm{R} \$ 150.000,00$ quanto a contratação de serviços de engenharia - e direcionamento de concorrentes, escolhidos pela administração pública, ela configura como possibilidade de contratação de serviços técnicos pela lei vigente e, portanto, deve ser também avaliada.

A execução da pesquisa foi realizada com a análise dos instrumentos de 40 processos licitatórios, distribuídos igualmente entre modalidades citadas anteriormente, 10 de cada. Os instrumentos analisados foram basicamente os editais de licitação e os termos de referência, além de documentos anexos do edital que pudessem conter as informações almejadas, a exemplo de projetos básicos e especificações técnicas.

As análises dos processos licitatórios também foram restritas à contratação de projetos para objeto certo, obra determinada, limitados a edificações novas e reformas ou 
modificações que envolvessem aumento de área construída, descartando da pesquisa editais elaborados com foco no sistema de registro de preço para obras diversas, bem como de projetos restritos à arquitetura de interiores e à readequação de layout.

Quanto a cronologia dos processos licitatório analisados a pesquisa se ateve a contratações realizadas a partir de 2010. Já quanto à tipologia funcional do objeto, que indica função à qual se destina, a análise ficou restrita a edificações instituições de uso administrativo e educacional, não havendo restrições quanto às esferas administrativas e à representatividade dos poderes e entidades da administração pública.

\subsection{Aplicação Ferramenta (01) - Identificação de Critérios e Diretrizes da Construção Industrializada}

Após a definição dos parâmetros de avaliação a serem considerados pela ferramenta de pesquisa, iniciou-a busca por processos de licitação que atendessem ao escopo de estudo do presente trabalho, realizado no âmbito da internet; tanto de forma ampla, através de sites de busca, quanto de forma específica, por meio de consulta a portais eletrônicos específicos de licitações.

São exemplos de portais eletrônicos específicos de licitações, os portais de transparência de diversas entidades, portal de transparência do governo federal e sites especializados em concursos de projeto, a exemplo do portal concursosdeprojeto.org.br e sites do diretório nacional e do Distrito Federal do Instituto de Arquitetos do Brasil (IAB-BR e IAB-DF, respectivamente).

A partir das análises verificou-se uma característica comum dos instrumentos de licitação, independentemente da modalidade, relacionada ao fato de que os critérios avaliados pela pesquisa geralmente estão localizados em itens do edital referentes à avaliação da proposta ou, principalmente, em itens relacionados às diretrizes ou princípios de projeto em termos de referência e em projetos básicos; sendo raras as vezes que os critérios avaliados apareceram ao longo do texto e de maneira genérica.

Dessa forma, a fim de tornar as análises mais objetivas, a avaliação dos instrumentos de licitação focou nos itens relacionados aos critérios de avaliação e às diretrizes ou princípios de projeto. Conforme explanado anteriormente, as análises dos instrumentos de licitação foram organizadas por modalidade, seguindo a ordem Concurso de Projeto, Concorrência, Tomada de Preços e Convite. 


\subsubsection{Modalidade Concurso de Projeto}

$\mathrm{Na}$ modalidade concurso, os dez processos licitatórios analisados foram realizados entre 2011 e 2016, sendo referentes a obras de edificações ou edificações e infraestrutura (caso da Universidade Federal de Ciência da Saúde de Porto Alegre - UFCSPA), tanto de uso administrativo, quanto de uso educacional.

As entidades contratantes dessa modalidade estão classificadas em diversas personalidades administrativas dos poderes executivo e legislativo, além de uma entidade classificada como associação civil - que, apesar de não ter classificação expressa em relação à administração pública pelo direito administrativo, utilizou uma modalidade típica de licitação - estando elas apresentadas e classificadas no Quadro 03.

\begin{tabular}{|c|c|c|c|}
\hline \multicolumn{4}{|c|}{ Modalidade Concurso } \\
\hline Entidade & Sigla & Localidade (UF) & $\begin{array}{l}\text { Personalidade } \\
\text { Jurídica }\end{array}$ \\
\hline $\begin{array}{l}\text { Banco Nacional de Desenvolvimento } \\
\text { Econômico e Social }\end{array}$ & BNDES & Rio de Janeiro - RS & Autarquia Federal \\
\hline $\begin{array}{l}\text { Governo do Maranhão - Centro } \\
\text { Administrativo do Maranhão }\end{array}$ & CA-MA & São Luís - MA & $\begin{array}{l}\text { Poder Executivo } \\
\text { Estadual }\end{array}$ \\
\hline $\begin{array}{l}\text { Prefeitura de Belo Horizonte - Centro } \\
\text { Administrativo de Belo Horizonte }\end{array}$ & $\mathrm{CA}-\mathrm{BH}$ & Belo Horizonte - $\mathrm{BH}$ & $\begin{array}{l}\text { Poder Executivo } \\
\text { Municipal }\end{array}$ \\
\hline $\begin{array}{l}\text { Conselho de Arquitetura e Urbanismo } \\
\text { do Brasil / Instituto dos Arquitetos do } \\
\text { Brasil - Diretório DF }\end{array}$ & $\begin{array}{l}\text { CAU-BR / } \\
\text { IAB-DF }\end{array}$ & Brasília - DF & $\begin{array}{l}\text { Autarquia Federal } \\
\text { / Associação Civil } \\
\text { Pública }\end{array}$ \\
\hline Câmara Municipal de Porto Alegre & CM-POA & Porto Alegre - RS & $\begin{array}{l}\text { Poder Legislativo } \\
\text { Municipal }\end{array}$ \\
\hline $\begin{array}{l}\text { Companhia de Desenvolvimento } \\
\text { Habitacional do Distrito Federal - } \\
\text { (Centro de Ensino Básico) }\end{array}$ & $\begin{array}{l}\text { CODHAB - } \\
\text { CEB }\end{array}$ & Brasília - DF & Empresa Pública \\
\hline $\begin{array}{l}\text { Companhia de Desenvolvimento } \\
\text { Habitacional do Distrito Federal - } \\
\text { (Centro de Ensino Fundamental) }\end{array}$ & $\begin{array}{l}\text { CODHAB - } \\
\text { CEF }\end{array}$ & Brasília - DF & Empresa Pública \\
\hline $\begin{array}{l}\text { Fundação do Meio Ambiente / } \\
\text { Fundação de Amparo à Pesquisa e } \\
\text { Inovação do Estado de Santa Catarina }\end{array}$ & $\begin{array}{l}\text { FATMA - } \\
\text { FAPESC }\end{array}$ & Florianópolis - SC & Fundação Pública \\
\hline $\begin{array}{l}\text { Instituto de Arquitetos do Brasil - } \\
\text { Diretório Tocantins }\end{array}$ & $\mathrm{IAB}-\mathrm{TO}$ & Palmas - TO & $\begin{array}{l}\text { Associação Civil } \\
\text { Pública }\end{array}$ \\
\hline $\begin{array}{l}\text { Universidade Federal de Ciências da } \\
\text { Saúde de Porto Alegre }\end{array}$ & UFCSPA & Porto Alegre - RS & Fundação Pública \\
\hline
\end{tabular}

Quadro 3: Lista de Entidades Contratantes - Modalidade Concurso.

Ao avaliar os processos licitatórios da modalidade concurso quanto ao nível de detalhamento do projeto - ou seja, quais etapas de projeto estariam contempladas pela contratação - verificou-se que apenas em duas circunstâncias a licitação não abrangeu 
todas as etapas de projeto, os processos licitatórios ao Anexo da Sede do BNDES e do Campus da UFCSPA, restritos às etapas de estudo preliminar e de anteprojeto.

As avaliações também permitiram constatar que nas circunstâncias em que os concursos ficaram restritos ao estudo preliminar e ao anteprojeto, a contratação quanto às especialidades técnicas também ficou restrita à especialidade arquitetura, sendo contempladas as demais especialidades.

Observou-se também que quando as contratações abrangeram todas as etapas de projeto, elas também se estenderam às demais especialidades de projeto, com exceção do processo referente à Câmara Municipal de Porto Alegre - onde, embora tenha sido exigido todas as etapas, ficou restrito à contratação dos projetos de arquitetura.

Já no que diz respeito ao compartilhamento de informações entre as especialidades técnicas envolvidas no projeto, constatou-se que não foi exigido ou mesmo sugerido a utilização da plataforma BIM como requisito de projeto nem a utilização de qualquer outra ferramenta, plataforma ou estratégia de compartilhamento de informações técnicas entre as especialidades.

\subsubsection{Avaliação dos aspectos técnicos - Modalidade Concurso}

A análise da categoria referente aos aspectos técnicos da modalidade concurso indica a predominância de resultados ruins, com 05 critérios dos 12 analisados, seguido por resultados intermediários; sendo que apenas dois critérios apresentaram bons resultados, conforme indica pelo Gráfico 01 , sendo os resultados detalhados a seguir.

\section{Aspectos Técnicos - Concurso}

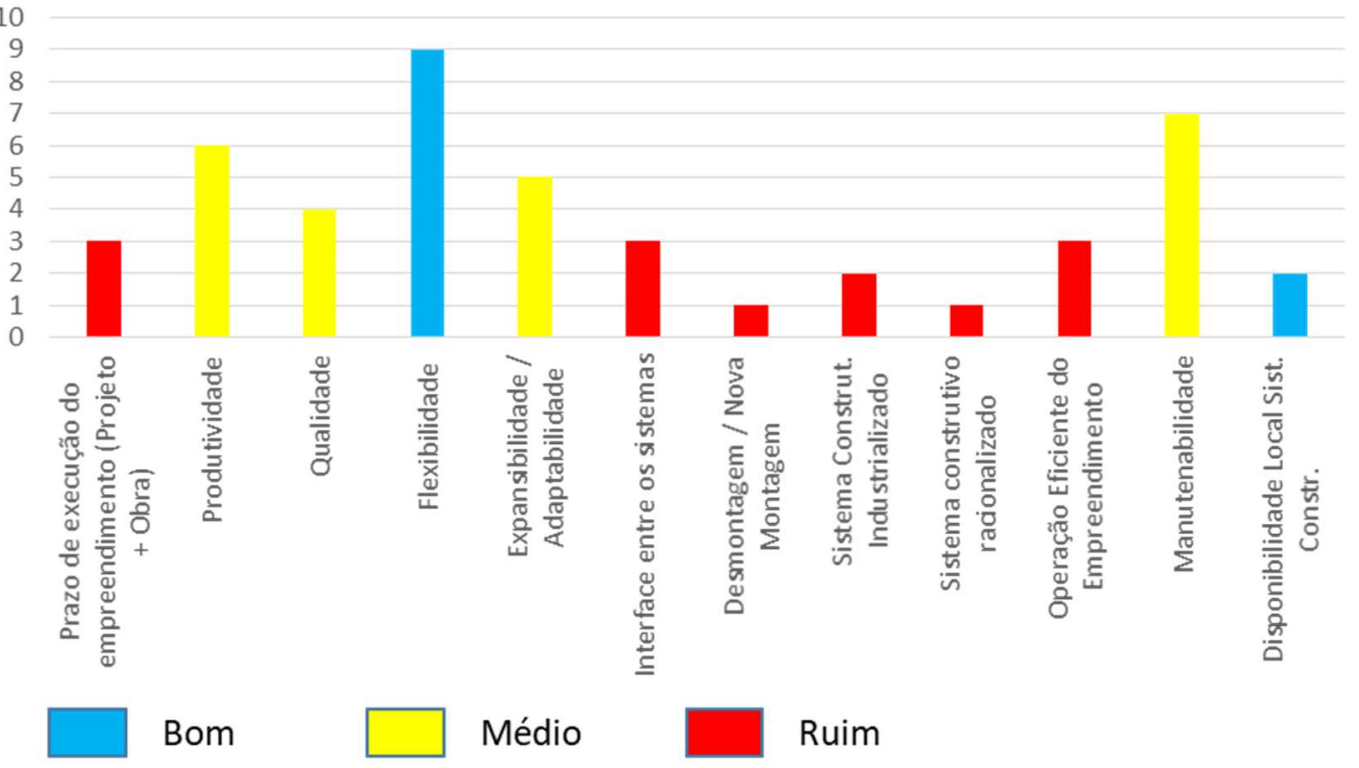

Gráfico 1: Resultados - Aspectos Técnicos / Modalidade Concurso 


\section{a) Prazo de Execução}

O critério referente à exigência do prazo como requisito como requisito de projeto foi identificado em 03 processos licitatórios da modalidade Concurso em 10 analisados, o que indica - seguindo a classificação proposta pela pesquisa - um resultado ruim ou insatisfatório, conforme o Gráfico 01.

Ao examinar os achados de pesquisa, verificou-se que em uma situação foi exigido que o planejamento da obra a ser projetada levasse em consideração a execução da obra em prazo determinado, enquanto que os outros dois casos determinaram o prazo final de entrega além de sugerir a utilização de sistemas capazes de diminuir o prazo de execução, conforme indicado no quadro 01 do Apêndice A.

b) Produtividade

A produtividade como requisito de projeto esteve presente em 06 processos licitatórios dos 10 analisados na modalidade concurso, apresentando um resultado intermediário, conforme a classificação adotada. A comparação entre os critérios referentes ao prazo e à produtividade indica uma maior atenção dispensada ao segundo por parte das entidades contratantes avaliadas, conforme o Gráfico 01 .

A análise das licitações dessa modalidade permitiu identificar diversos termos vinculados ao conceito de produtividade, como exequibilidade, velocidade da construção, agilidade construtiva, além da presença de atributos e requisitos característicos dos sistemas construtivos industrializados que implicam em ganhos de produção, a exemplo da modulação e da padronização, conforme o quadro 02 do Apêndice A.

c) Qualidade

$\mathrm{O}$ critério referente à qualidade esteve presente em 04 licitações da modalidade concurso, indicando um resultado intermediário, o que caracteriza uma solicitação abaixo da importância que esse fator representa em um projeto e a sua consequente obra, conforme o Gráfico 01.

Porém, ao analisar os achados de pesquisa, observa-se que o conceito de qualidade presente nos instrumentos licitatórios é abordado de maneira ampla, sem fazer qualquer restrição conceitual ou indicar de forma clara o conceito de qualidade considerado pela pesquisa, que trata da regularidade, do nível de acabamento e da padronização dos componentes, conforme indicado no quadro 03 do Apêndice A.

d) Flexibilidade

$\mathrm{O}$ critério referente à flexibilidade de uso apresentou o melhor resultado dentre todos os critérios da modalidade concurso ao estar presente em 09 processos licitatórios 
de 10 processos analisados, conforme o Gráfico 01 . Tal resultado indica uma expressiva busca por edificações que permitam maior dinâmica e versatilidade quanto ao uso e, consequentemente, às suas configurações.

Além do termo flexibilidade, os instrumentos licitatórios analisados e contemplados pelo presente critério apresentaram outros termos capazes de expressar a mesma ideia ou complementá-la, tais como a multifuncionalidade e a reversibilidade dos espaços e ambientes construídos, conforme indicado pelo quadro 04 do Apêndice A.

e) Expansibilidade ou Adaptabilidade

Os conceitos de Expansibilidade e Adaptabilidade, colocados no mesmo critério de avaliação, foram abordados em 05 processos dos 10 avaliados, indicando um resultado intermediário, de acordo com a escala adotada pela presente pesquisa, conforme indicado no Gráfico 01.

Destaca-se ainda que, ao comparar os resultados dos critérios referentes à Flexibilidade e à Expansibilidade, pode ser observada uma preferência por soluções arquitetônicas mais flexíveis quanto ao uso do que por soluções que permitam maior possibilidade de adaptação e expansão da estrutura da edificação e de sua área construída.

Ao observar os achados de pesquisa, indicados no quando 05 do Apêndice B, constatou-se que em algumas licitações a questão da expansibilidade foi abordada de maneira indireta, exigindo a capacidade das soluções arquitetônicas em atender demandas futuras de espaço físico e facilitar a modificação dos espaços e dos sistemas da edificação.

f) Interface entre os Sistemas

O critério que trata da interface entre os sistemas ou componentes esteve presente em 03 processos dos 10 analisados, representando um resultado insatisfatório de acordo com os parâmetros adotados pela pesquisa, conforme indicado no Gráfico 01. Destaca-se ainda que o tema da interface entre os sistemas foi abordado a partir da ideia de entrosamento entre os sistemas e elementos ou pelo funcionamento harmônico do conjunto de sistemas que compõem a edificação, conforme o quadro 06 do Apêndice A.

g) Desmontagem e Remontagem

$\mathrm{O}$ critério referente à desmontagem e remontagem dos sistemas, que remete à ideia de uma arquitetura que permita sua desconstrução após o término de sua operação ou de sua vida útil, esteve presente em apenas um processo licitatório na modalidade concurso, conforme o Gráfico 01 e o quadro 07 do Apêndice A; o que indica um resultado negativo ou insatisfatório de acordo com os padrões adotados pela pesquisa.

h) Sistema Construtivo Industrializado 
A exigência expressa por parte das entidades contratantes quanto à utilização de sistemas construtivos industrializados, conforme a definição elaborada no capítulo anterior, nas soluções de projeto foi identificada em dois processos licitatórios da modalidade concurso, conforme o Gráfico 01.

Porém, a abordagem do critério foi realizada de forma indireta, nos processos do CAU-BR / IAB-DF e CM-POA, uma vez que foram utilizados termos que podem direcionar a escolha de sistemas industrializados, tais como novas tecnologias e sistema construtivo moderno e eficiente - nomenclatura similar à utilizada no contexto britânico, conforme demonstrado nos achados de pesquisa indicados no quadro 08 do Apêndice A.

i) Sistema Construtivo Racionalizado

A exigência da utilização de sistemas construtivos racionalizados nas soluções de projeto esteve presente em apenas um processo de licitação na modalidade concurso, no processo do Anexo da sede do BNDES, conforme o Gráfico 01; o que indica um resultado ruim ou insatisfatório, conforme o parâmetro adotado pela pesquisa.

j) Operação eficiente do empreendimento

A requisição por soluções de projeto que considerem a operação eficiente do empreendimento foi identificada em apenas três processos licitatórios, configurando como um resultado insatisfatório, indicado no Gráfico 01. Vale destacar que as circunstâncias em que esse critério foi identificado, o mesmo esteve associado à questão da manutenção ou da economicidade, conforme indicado pelos achados de pesquisa sintetizados no quadro 10 do Apêndice A.

k) Manutenção

A preocupação com a manutenção do empreendimento, que caracteriza o presente critério, esteve presente em sete processos dos 10 analisados na modalidade concurso, o que indica uma relativa importância do tema, ainda que não tenha alcançado o nível de satisfação adotado pela pesquisa - conforme indicado no Gráfico 01.

A análise dos achados de pesquisa referentes ao critério que trata da manutenção revelou que tanto os aspectos econômicos da manutenção, a fim de reduzir seus custos, quanto os aspectos operacionais das atividades de manutenção, que tem o objetivo de facilitar os reparos e substituições de sistemas e componentes, estão contemplados nos instrumentos dos processos analisados, conforme indicado no quadro 11 do Apêndice A.

1) Disponibilidade local dos sistemas construtivos

$\mathrm{O}$ critério referente à disponibilidade local dos sistemas esteve presente em apenas dois processos licitatórios da modalidade concurso, indicando um resultado insatisfatório 
- conforme indicado no Gráfico 01. Os achados de pesquisa revelam que a abordagem do presente critério considerou os impactos ambientais decorrentes do transporte entre as localidades de sua produção e da obra, conforme o quadro 12 do Apêndice A.

Destaca-se ainda que devido ao fato de a exigência pela disponibilidade local dos sistemas poder limitar o uso de sistemas construtivos industrializados caso não haja a produção desses sistemas na localidade da obra, conforme abordado no capítulo anterior, conclui-se que o resultado obtido por esse critério na modalidade corrente pode ser considerado positivo.

\subsubsection{Avaliação dos aspectos ambientais - Modalidade Concurso}

A análise da categoria que trata dos aspectos ambientais da modalidade concurso demonstra ausência de bons resultados e o empate da quantidade de critérios com resultados ruins e intermediários, com 03 critérios para cada, conforme indicado pela Gráfico 02.

\section{Aspectos Ambientais - Concorrência}

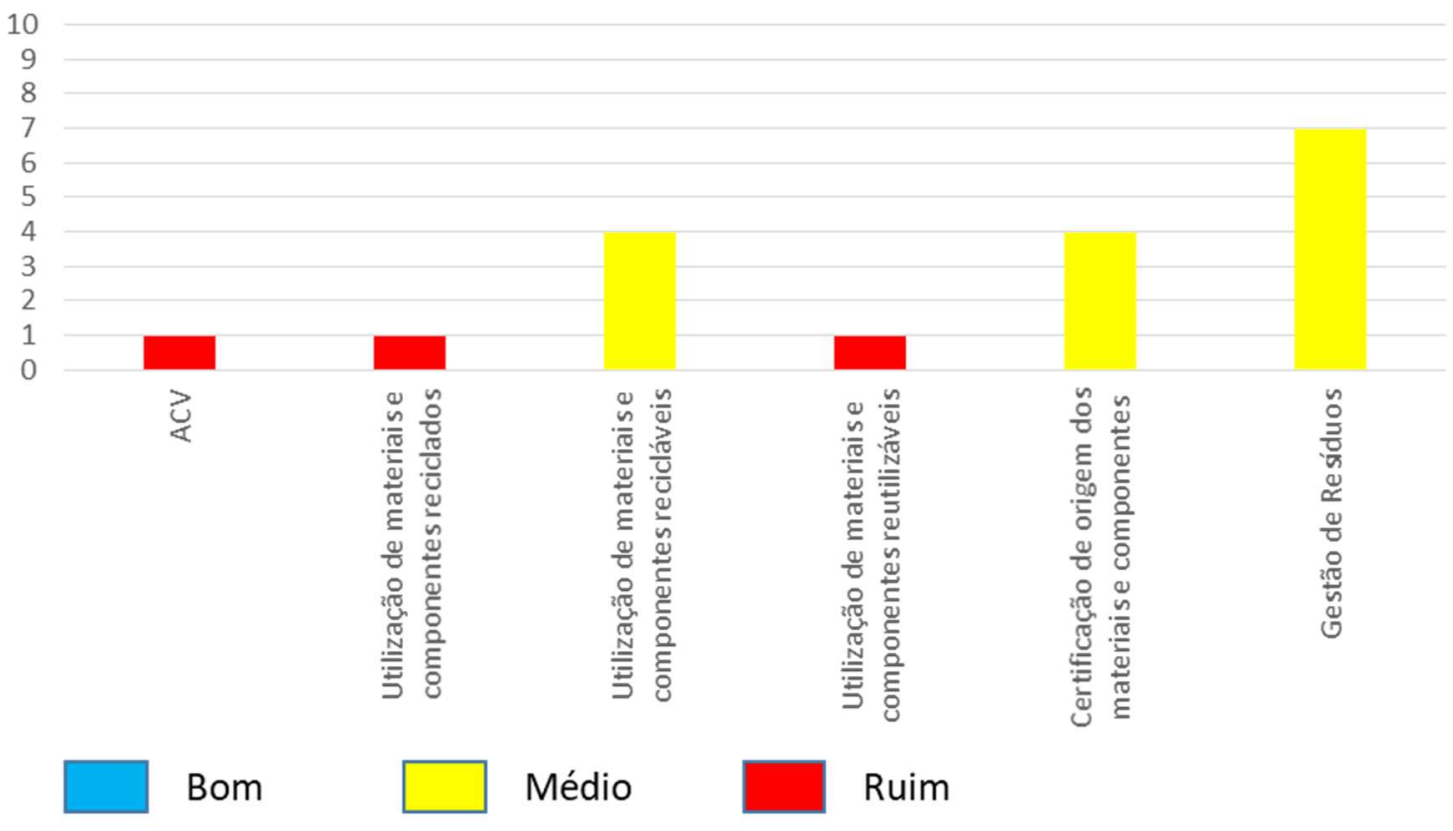

Gráfico 2: Aspectos Ambientais / Modalidade Concurso

a) $\mathrm{ACV}$

A Avaliação do Ciclo Vida foi identificada em apenas um processo licitatório, indicando um desempenho ruim dos instrumentos licitatórios da modalidade concurso quanto a esse tema, conforme ilustra o Gráfico 02. Destaca-se ainda que a presença do critério em questão não utilizou diretamente o termo ACV, mas a requisição de soluções que considerem as diversas fases do ciclo de vida, conforme o quadro 1 do Apêndice B. 
b) Utilização de materiais e componentes reciclados

O critério que trata da utilização de materiais e componentes reciclados como premissa de projeto foi identificado em apenas um processo licitatório da modalidade concurso, conforme indicado no Gráfico 02 , sendo classificado como um resultado ruim ou insatisfatório. Vale destacar que os materiais reciclados receberam a classificação de materiais não convencionais, conforme demonstrado pelos achados de pesquisa representados no quadro 02 do Apêndice B.

c) Utilização de materiais e componentes recicláveis

A exigência ou requisição pela utilização de materiais e componentes que apresentam a possibilidade de reciclagem nas soluções de projeto da modalidade concurso foi identificada 04 processos de licitação, conforme indicado no Gráfico 08. Esse número representa um resultado regular conforme a escala adotada pela pesquisa.

Conforme observado nos achados de pesquisa, sintetizados no quadro 03 do Apêndice B, a promoção da reciclagem dos materiais e componentes esteve relacionada tanto com a questão da gestão de resíduos quanto a racionalização da exploração e utilização dos recursos naturais.

d) Utilização de materiais e componentes reutilizáveis

A reutilização de materiais e componentes dos sistemas construtivos como premissa de projeto esteve presente em apenas um processo de licitação, conforme o Gráfico 02, indicando um resultado negativo desse critério. Ainda foi observado que a tratativa da reutilização no processo licitatório que contemplou o presente critério esteve relacionada à questão ambiental, sem mencionar a questão econômica, tal como indicado pelo quadro 04 do Apêndice B.

e) Certificação de origem de materiais e componentes

A premissa sobre a certificação de origem dos materiais e componentes especificados, relacionada ao processo de compra responsável, foi identificada em 04 processos dos 10 analisados na modalidade concurso. $\mathrm{O}$ resultado indica uma adesão intermediária das entidades contratantes da modalidade concurso ao processo de compra responsável, tal como indicado pelo Gráfico 02.

De acordo com o que foi observado nos achados de pesquisa, indicados no quadro 05 do Apêndice B, a certificação de origem foi exigida de maneira expressa em 03 processos licitatórios e indiretamente em uma circunstância, ao destacar a importância de considerar todas as etapas do processo - que contempla da extração dos materiais (origem) à possível reciclagem. 


\section{f) Gestão de Resíduos}

A gestão de resíduos como premissa de projeto esteve presente em 07 processos licitatórios na modalidade concurso, conforme o Gráfico 02. Esse contingente que indica um resultado relevante, ainda que seja classificado como intermediário pelo parâmetro utilizado na presente pesquisa.

Também é possível destacar que o presente critério esteve relacionado à redução das perdas construtivas em três circunstâncias, conforme indicado pelo quadro 06 do Apêndice B. A gestão de resíduos também foi relacionada à destinação adequada dos resíduos e à possibilidade da realização de reparos sem geração de resíduos.

\subsubsection{Avaliação dos aspectos socioeconômicos - Modalidade Concurso}

A categoria referente aos aspectos socioeconômicos aborda dois temas macro, o custo e o tipo de mão de obra, sendo que a análise dessa categoria na modalidade concurso indica a relevância do primeiro tema e a irrelevância do segundo para as entidades que adotaram essa modalidade, conforme indicado pelo Gráfico 03.

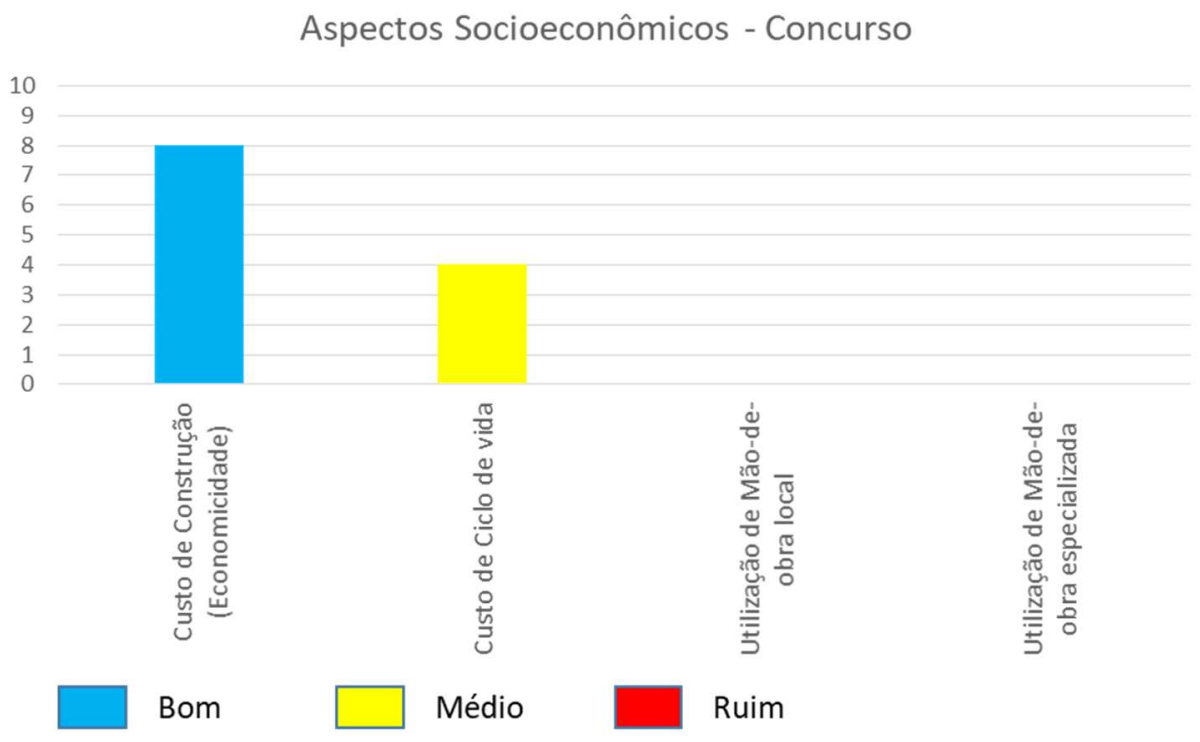

Gráfico 3: Resultados - Aspectos Socioeconômicos / Modalidade Concurso

a) Custo de Construção (Economicidade)

O primeiro critério abordado na categoria referente aos aspectos socioeconômicos trata do Custo de Construção ou a Economicidade. Na modalidade concurso esse critério esteve presente 08 processos dos 10 analisados, conforme o Gráfico 03; sendo esse resultado considerado satisfatório, o que indica uma considerável busca por soluções de projeto que tenham em vista a economia nos custos de execução da obra.

Os achados de pesquisa sobre o presente critério demonstram que a economicidade foi abordada tanto de maneira conceitual quanto de modo objetivo, quando a entidade 
contratante informa o valor máximo que pretende destinar para a execução da obra, conforme indicado pelo quadro 01 do Apêndice C.

b) Custo de Ciclo de vida

O critério referente ao custo do ciclo de vida, que adiciona o custo de operação e demolição ao custo de execução da obra, esteve presente em 04 processos analisados, conforme indicado no Gráfico 03; o que indica um resultado intermediário.

Embora o termo "Custo de Ciclo de Vida" não tenha sido utilizado nos processos considerados, termos equivalentes foram adotados - tais como baixos custos de manutenção, sustentabilidade econômica e custo ao longo do tempo, conforme demonstrado pelo quadro 02 do Apêndice C.

c) Utilização de mão de obra local e Utilização de Mão de Obra especializada

Conforme citado anteriormente, os critérios referentes à requisição da previsão de utilização de mão de local e de mão de obra especializada não foram contemplados pelos processos licitatórios da modalidade concurso - conforme indicado pela Gráfico 03.

\subsubsection{Modalidade Concorrência}

Os dez processos licitatórios analisados na modalidade Concorrência são referentes à contratação de projetos para edificações e realizados entre 2013 e 2016, sendo as entidades pertencentes a quadros dos poderes executivo, legislativo e judiciário e classificadas quanto a personalidade jurídica e a localidade, conforme o Quadro 04.

Modalidade Concurso

\begin{tabular}{|c|c|c|c|}
\hline \multicolumn{4}{|c|}{ Viodallade concurso } \\
\hline Entidade & Sigla & Localidade (UF) & Personalidade Jurídica \\
\hline Assembléia Legislativa do Ceará & $A L-C E$ & Fortaleza - CE & Poder Legislativo Estadual \\
\hline $\begin{array}{l}\text { Escola Nacional de } \\
\text { Administração Pública }\end{array}$ & ENAP & Brasília - DF & Fundação Pública \\
\hline Instituto Federal do Maranhão & IFMA & São Luís - MA & Fundação Pública \\
\hline $\begin{array}{l}\text { Instituto Federal do Triângulo } \\
\text { Mineiro }\end{array}$ & IFTM & Diversas - MG & Fundação Pública \\
\hline $\begin{array}{l}\text { Procuradoria Geral do Município } \\
\text { de Porto Alegre }\end{array}$ & PGM - POA & Porto Alegre - RS & Secretaria Municipal \\
\hline Superior Tribunal Militar & STM & Brasília - DF & Poder Judiciário Federal \\
\hline Tribunal de Justiça de Rondônia & TJ-RO & Porto Velho - RO & Poder Judiciário Estadual \\
\hline $\begin{array}{l}\text { Universidade Estadual do Piauí - } \\
\text { Campus Clóvis Moura }\end{array}$ & UESPI - CM & Teresina - PI & Fundação Pública \\
\hline $\begin{array}{l}\text { Universidade Estadual do Piauí - } \\
\text { Campus Torquato Neto }\end{array}$ & UESPI - TN & Teresina - PI & Fundação Pública \\
\hline $\begin{array}{l}\text { Universidade Federal de } \\
\text { Uberlândia }\end{array}$ & UFU & Uberlândia - MG & Fundação Pública \\
\hline
\end{tabular}

Quadro 4: Lista de Entidades Contratantes - Modalidade Concurso. 
A avaliação dos processos licitatórios quanto ao nível de detalhamento dos projetos revelou que todas as contratações contemplaram todas as etapas de projeto, do estudo preliminar ao projeto executivo. Verificou-se também que, quanto às especialidades técnicas, todos os processos de licitação analisados optaram pela contratação de projetos integrados, englobando as diversas especialidades técnicas.

A respeito da categoria referente ao compartilhamento de informações verificou-se que não houve indicação dos critérios da categoria em questão - a utilização de Ferramenta, Plataforma ou estratégia de compartilhamento de informações técnicas e a utilização da plataforma BIM - em 06 processos - ENAP, IFMA, IFTM, TJ-RO, UESPI (Campus Clóvis Moura e Campus Torquato Neto).

Foi constatado também que em apenas um processo, na licitação promovida pelo STM, houve a requisição de ambos os critérios e que nos processos restantes apenas a utilização de ferramenta, plataforma ou estratégia de compartilhamento de informações foi identificada, não sendo exigida ou recomendada a utilização da Plataforma BIM.

\subsubsection{Avaliação dos aspectos técnicos - Modalidade Concorrência}

A categoria que trata dos aspectos técnicos na modalidade Concorrência apresentou um certo equilíbrio entre os resultados dos diversos critérios, ao indicar 03 resultados intermediários, 04 bons resultados e 05 ruins, conforme indicado pelo Gráfico 04. Tais resultados indicam uma leve melhora de modo geral, dos resultados dessa categoria na modalidade em questão se comparada à modalidade concurso, anteriormente analisada.

\section{Aspectos Técnicos - Concorrência}

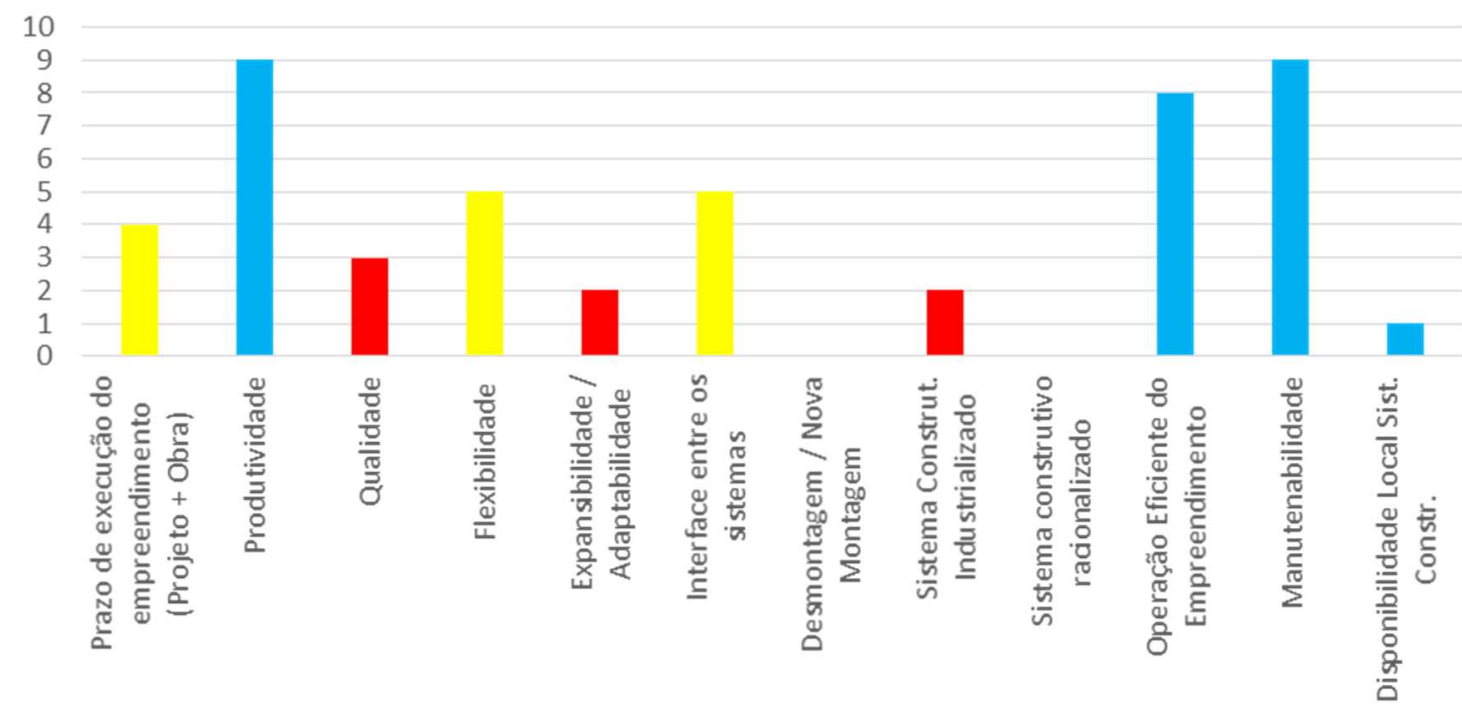

Bom

Médio

Ruim

Gráfico 4: Resultados - Aspectos Técnicos / Modalidade Concorrência. 


\section{a) Prazo de Execução}

O critério que trata do prazo de construção (ou entrega) do empreendimento como premissa de projeto foi abordado em 04 processos licitatórios da modalidade Concorrência, tal como ilustrado pelo Gráfico 04, indicando um resultado intermediário.

Os achados de pesquisa do presente critério na modalidade em questão indicam que a questão da redução do tempo de execução da obra foi abordada de maneira a associar o prazo com os ganhos de produtividade e com a substituição de serviços e sistemas artesanais por elementos industrializados e novas tecnologias, conforme indicado no quadro 01 do Apêndice D.

b) Produtividade

O critério referente ao conceito de produtividade como requisito de projeto esteve presente em 09 processos de licitação dos 10 analisados na modalidade concorrência, apresentando um resultado satisfatório. Assim como aconteceu na modalidade concurso, a comparação entre prazo e produtividade indicou uma participação maior do segundo critério - conforme o Gráfico 04.

O conceito de produtividade foi abordado de forma diversa nos diferentes processos licitatórios da modalidade concorrência, sendo trabalhado tanto a partir da ideia ampla de facilitar a execução quanto de buscar atributos e requisitos comuns nos sistemas construtivos industrializados - tais como soluções racionais, padronizadas e modulares.

Outro ponto observado foi a semelhança na abordagem do tema em processos distintos, conforme demonstrado o quadro 02 do Apêndice D. Essa semelhança pode ser justificada pela adoção do texto do Manual de Obras Públicas da Secretaria de Estado da Administração e Patrimônio - SEAP (BRASIL, 1997) de forma literal, havendo circunstâncias que entidades diferentes utilizam o mesmo texto.

c) Qualidade:

O critério que trata do conceito de qualidade como premissa de projeto foi identificado em 03 processos de licitação da modalidade concorrência, indicando um resultado ruim e a pouca importância dada a esse critério no processo de planejamento das obras públicas nessa modalidade - conforme demonstrado no Gráfico 04.

Os achados de pesquisa mostram que os processos que consideram a questão da qualidade a partir da ideia de padronização de elementos e da busca pela qualidade no acabamento superficial, além do objetivo de facilitar manutenção da edificação, tal como demonstrado no quadro 03 do Apêndice D. 


\section{d) Flexibilidade}

A solicitação de soluções de projeto que considerem a flexibilidade de uso esteve presente em 05 processos licitatórios dos 10 analisados na modalidade concorrência, retratando um resultado intermediário conforme classificação adotada pela pesquisa, conforme o Gráfico 04.

Os achados de pesquisa, sintetizados no quadro 04 do Apêndice D, demonstram que, além do conceito amplo de flexibilidade, o presente critério também foi abordado a partir do direcionamento das soluções de projeto - a exemplo da solicitação da previsão de laje livre e divisórias leves. Outro ponto a ser destacado é a semelhança da abordagem do presente critério por diferentes entidades - assim como ocorreu no critério qualidade.

e) Expansibilidade

O critério que trata da facilidade de expansão e adaptação das estruturas da edificação foi identificado em 02 processos de licitação dos 10 analisados na modalidade concorrência, o que indica um resultado ruim e a pouca importância atribuída à possibilidade de alterar a configuração da edificação de maneira facilitada e com agilidade, conforme informado pelo Gráfico 04.

A partir dos achados de pesquisa, representados no quadro 05 do Apêndice D, é possível observar que a questão da adaptabilidade e da expansibilidade foi abordada sob a perspectiva do aumento da demanda por mais espaço (devido a possibilidade de aumento dos usuários) e dos atributos e requisitos de projeto comuns dos sistemas construtivos industrializados, tais como a padronização e a modulação.

Outro ponto a ser considerado é a relação entre os resultados apresentados pelos critérios referentes à Flexibilidade e à Expansibilidade, uma vez que indica um maior apreço das contratantes da modalidade concorrência quanto ao primeiro critério, embora a diferença entre os resultados desses critérios tenha reduzido se comparada aos resultados desses critérios na modalidade concurso.

f) Interface

A questão da qualidade das soluções de projeto quanto à interface entre sistemas e componentes distintos esteve presente 05 processos licitatórios, conforme demonstrado pelo Gráfico 04, indicando um resultado intermediário para esse critério.

A interface entre sistemas e componentes foi tratada de forma similar por entidades distintas, conforme demonstrado pelo quadro 06 do Apêndice $\mathrm{D}$, assim como ocorreu nos critérios anteriores. Essa semelhança também está relacionada com a utilização do manual de Obras Públicas da SEAP. 


\section{g) Desmontagem / Nova Montagem}

O critério que trata da possibilidade de desmontagem e remontagem dos sistemas construtivos da edificação como requisito de projeto não foi contemplado pelos processos licitatórios da modalidade concorrência, indicando o desapreço pelo critério em questão por parte das entidades contratantes dessa modalidade, conforme indicado no Gráfico 04.

h) Sistema Construtivo Industrializado

A requisição da utilização de sistemas construtivos industrializados como premissa de projeto foi identificada em apenas 02 processos de licitação da modalidade concorrência, indicando um resultado negativo - conforme indicado no Gráfico 04.

i) Sistema Construtivo Racionalizado

Assim como ocorreu com critério referente à desmontagem e remontagem, 0 critério que trata da utilização de sistemas racionalizados como requisito de projeto não foi contemplado pelos processos licitatórios da modalidade concorrência, o que também indica a não observância desse critério na etapa inicial do planejamento da obra pública.

j) Operação eficiente do empreendimento

O critério que aborda a operação eficiente do empreendimento foi retratado em 09 processos licitatórios da modalidade concorrência, o que indica um resultado satisfatório do ponto de vista objetivo e seguindo a classificação adotada pela pesquisa - tal como demonstrado pelo Gráfico 04.

Vale destacar que os achados de pesquisa, sintetizados no quadro 10 do Apêndice $\mathrm{D}$, demonstram a adoção do mesmo texto em cinco processos licitatórios, que também tomam por base o manual de Obras Públicas da SEAP. Outro ponto a ser destacado é a utilização do conceito de conservação para abordar o presente critério, que foi trabalhado em outros três processos licitatórios - também indicados nos achados de pesquisa já mencionados.

k) Manutenção

De forma semelhante ao critério anterior, a questão da facilidade de manutenção dos empreendimentos públicos como premissa de projeto foi abordada em 09 processos da modalidade concorrência, conforme o Gráfico 04. E assim como ocorreu no critério que trata da operação, a redação dos achados de pesquisa foi retirada do Manual da SEAP e foi utilizada em 06 processos de maneira idêntica.

Observou-se ainda, a partir dos achados de pesquisa (representados no Quadro 11 do Apêndice D), que a questão da manutenção esteve associada tanto com a questão do 
custo quanto com os aspectos operacionais, ao tratar da facilitação dos procedimentos necessários à manutenção.

1) Disponibilidade Local dos Sistemas

A requisição pela preferência por soluções que contemplem os sistemas disponíveis na localidade da obra esteve presente em apenas um processo licitatório da modalidade concorrência, conforme indicado no Gráfico 04.

Porém, conforme já abordado anteriormente, esse critério deve ser analisado de maneira inversa dada a possibilidade de o mesmo servir como um entrave a adoção de sistemas inovadores, caso estes não estejam disponíveis na localidade da obra. Dessa forma, esse resultado pode ser considerado positivo.

\subsubsection{Avaliação dos aspectos ambientais - Modalidade Concorrência}

No tocante à tratativa dos aspectos ambientais nos processos de licitação da modalidade concorrência, foi identificado um desempenho insatisfatório em todos os critérios dessa categoria - conforme indicado no Gráfico 05. Esse resultado demonstra que a questão ambiental não teve peso relevante no processo de tomada de decisão das entidades contratantes que adotaram a modalidade concorrência para contratar serviços de elaboração de projetos técnicos.

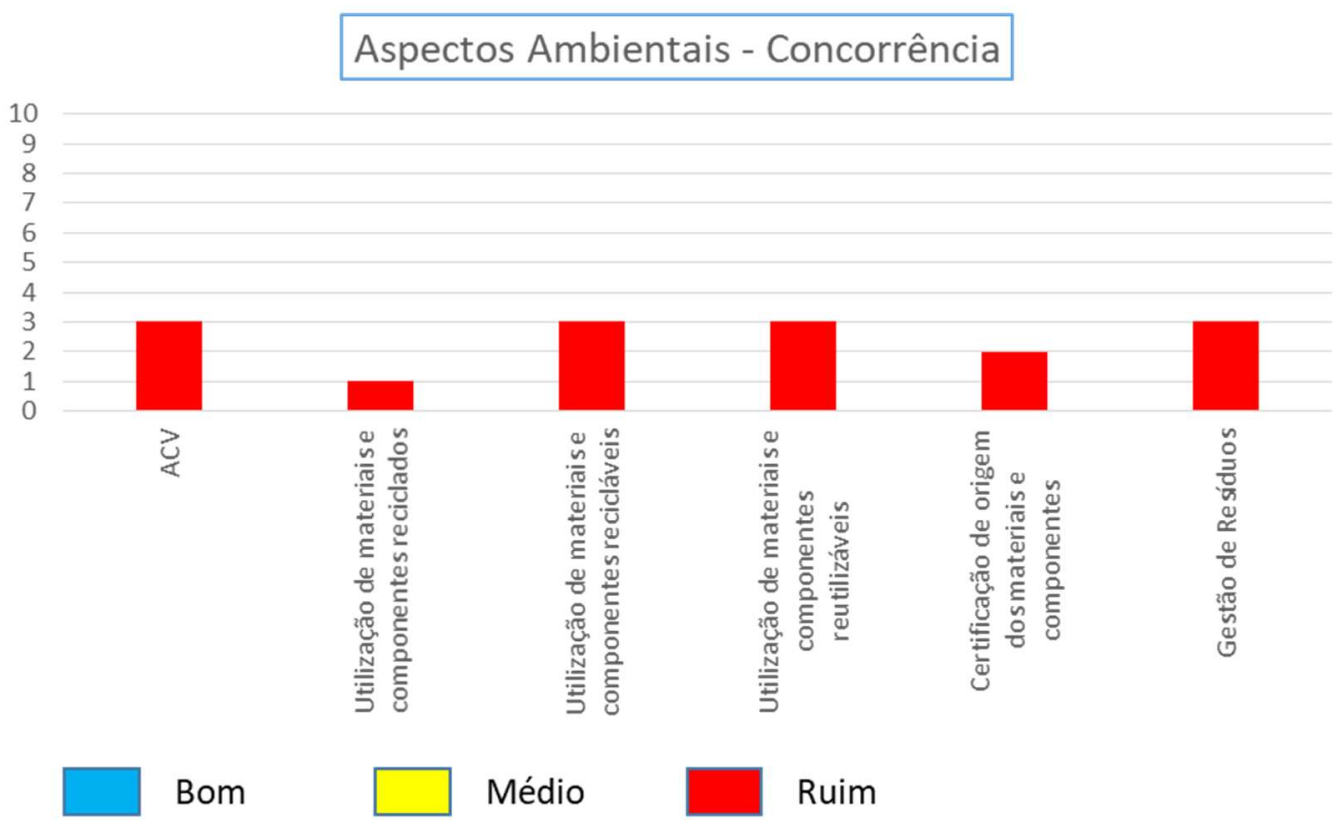

Gráfico 5: Resultados - Aspectos Ambientais / Modalidade Concorrência.

a) $\mathrm{ACV}$

O critério referente à Avaliação do Ciclo de Vida dos sistemas e seus respectivos materiais como premissa de projeto foi identificado em 03 processos licitatórios da modalidade concorrência, indicando um resultado negativo - conforme indicado pelo 
Gráfico 05. Esse resultado corrobora o baixo desempenho desse critério já apresentado na modalidade concurso.

Os achados de pesquisa referentes ao critério em questão, sintetizados no quadro 01 do Apêndice E, indicam que o ACV foi abordado de forma indireta, uma vez que as entidades fazem apenas uma solicitação de que as soluções tenham em vista o desenvolvimento sustentável ao longo do Ciclo de Vida da construção, sem exigir de forma expressa a elaboração da ACV para as soluções de projeto.

Outro aspecto identificado a partir da análise dos achados de pesquisa é a adoção do mesmo texto para retratar o tema por diferentes entidades contratantes, novamente tendo por base o Manual de Obras Públicas da SEAP, assim fora identificado em critérios da categoria que trata dos aspectos técnicos.

b) Utilização de materiais e componentes reciclados

Assim como ocorreu na modalidade concurso, o critério referente à utilização de materiais e componentes reciclados esteve presente em apenas um processo licitatório da modalidade concorrência, o que se considera um resultado ruim ou insatisfatório conforme indicado pelo Gráfico 05 .

A análise do único processo que contempla o critério em questão, indicado no quadro 03 do Apêndice $\mathrm{E}$, indica que os materiais reciclados são retratados como materiais de baixo impacto ambiental e está relacionado com a questão da geração de resíduos.

c) Utilização de materiais e componentes recicláveis

$\mathrm{O}$ critério referente à utilização de materiais e componentes que apresenta a possibilidade de reciclagem nas soluções de projeto da modalidade concorrência esteve presente em 03 processos licitatórios, conforme indicado no Gráfico 05, representando um baixo desempenho desse critério.

Os achados de pesquisa, demonstrados no quadro 04 do Apêndice E, indicam que o presente critério foi associado ao conceito de sustentabilidade ambiental e econômica bem como à ideia de gestão de resíduos.

d) Utilização de materiais reutilizáveis

A utilização de materiais e componentes com a possibilidade de reutilização nas soluções de projeto foi identificada em 02 processos licitatórios da modalidade concorrência, indicando mais um resultado ruim no tocante à temática ambiental no processo de planejamento das obras públicas. 
Conforme observado nos achados de pesquisa, indicados no quadro 04 do Apêndice $\mathrm{E}$, a questão da reutilização dos materiais e componentes foi relacionada às questões da sustentabilidade e da gestão de resíduos.

e) Certificação de origem dos materiais e componentes

O processo de compra responsável, representado pelo critério que trata da certificação de origem dos materiais e componentes, foi adotado em apenas 02 processos licitatórios da modalidade concorrência, conforme indicado no Gráfico 05, indicando um resultado ruim - de acordo com o critério de avaliação adotado pela pesquisa.

f) Gestão de Resíduos

O critério que aborda a gestão de resíduos como premissa de projeto foi identificado em 03 processos da modalidade concorrência, como demonstrado pelo Gráfico 05 , o que consiste em um resultado negativo.

Os fragmentos dos instrumentos licitatórios que tratam do presente critério, sintetizados no quadro 06 do Apêndice E, permitem observar que a gestão de resíduos foi abordada nos processos de contratação de projetos a partir da sua associação com as questões relacionadas à reciclagem e reuso dos materiais e componentes e com os impactos no meio ambiente decorrentes da destinação dos resíduos produzidos.

\subsubsection{Avaliação dos aspectos Socioeconômicos - Modalidade Concorrência}

A categoria que trata dos aspectos socioeconômicos apresentou resultados diversificados na modalidade concorrência, sendo que os critérios referentes aos custos de execução e de ciclo de vida apresentaram resultados melhores que os critérios que tratam da mão de obra - conforme indicado no Gráfico 06.

\section{Aspectos Socioeconômios - Concorrência}

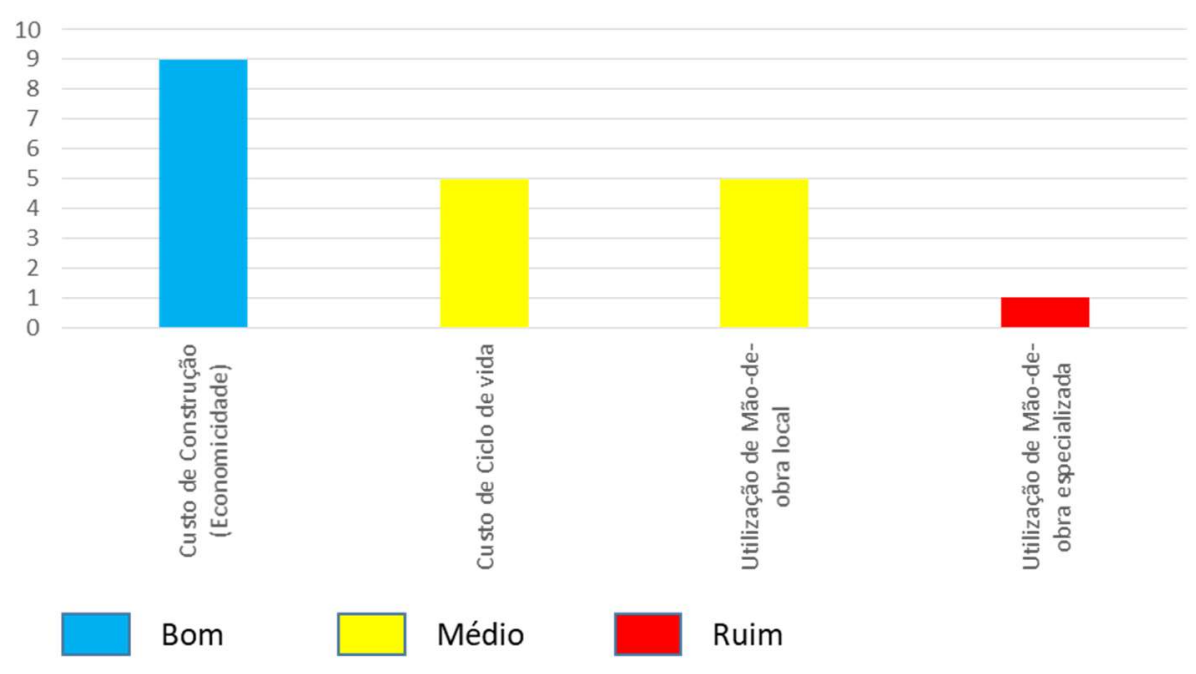

Gráfico 6: Resultado / Aspectos Socioeconômicos - Modalidade Concorrência. 
a) Custo de Construção (Economicidade)

O critério que trata do custo de execução do empreendimento ou da economicidade das soluções como premissa de projeto foi identificado em 09 processos da modalidade concorrência dos 10 analisados, conforme indicado pelo Gráfico 06. Esse resultado indica um apreço considerável das entidades contratantes quanto a questão econômica dos empreendimentos, corroborando o resultado identificado na modalidade concurso.

Assim como ocorreu em critérios das categorias referentes aos aspectos técnicos e ambientais, os achados de pesquisa - representados no quadro 01 do Apêndice F revelam a semelhança entre as redações de processos distintos na abordagem do custo como premissa de projeto, também oriundas do Manual de Obras Públicas da SEAP.

Outro ponto a ser destacado é que não foi identificado nos achados de pesquisa a determinação do valor máximo a ser dispendido na obra, sendo a questão do custo abordada de forma mais genérica - solicitando a adoção de soluções que considerem as disponibilidades econômicas e financeiras para a implantação do terreno.

A diferença de abordagem da questão do custo entre as modalidades concurso e concorrência pode ser justificada pelo fato de a modalidade concurso avaliar o objeto projeto apresentado -enquanto que a modalidade concorrência avalia o contratado, e a elaboração do projeto é iniciada após a contratação do prestador de serviço, diferentemente da modalidade concurso.

b) Custo de Ciclo de Vida

Custo de Ciclo de Vida como requisito de projeto foi identificado em 05 processos de licitação da modalidade concorrência, sendo este um resultado intermediário, conforme indicado no Gráfico 06.

Assim como ocorreu na modalidade concurso, a questão do custo do ciclo de vida foi abordada a partir da ideia da redução do custo de operação e manutenção, além da questão da sustentabilidade econômica do empreendimento, conforme indicado pelo quadro 02 do Apêndice F.

c) Utilização de mão de obra local

O critério que trata da utilização de mão obra local como premissa ou requisito de projeto foi identificado em 05 processos da modalidade concorrência, também indicando uma importância moderada ao presente critério por parte das entidades contratantes, conforme o Gráfico 06.

Mais uma vez, os achados de pesquisa do critério em questão, indicados no quadro 03 do Apêndice F, demonstram a utilização da mesma redação por entidades diferentes 
para abordar a mesma questão, sendo o texto base também extraído do Manual de Obras Públicas da SEAP.

d) Utilização de mão de obra especializada

Por fim, o critério referente à requisição de soluções que privilegiem a utilização de mão de obra especializada não foi identificado nos processos licitatórios da modalidade concorrência, conforme demonstrado no Gráfico 06, repetindo o desempenho desse critério na modalidade concurso.

\subsubsection{Modalidade Tomada de Preços}

Nas avaliações da modalidade Tomada de Preços, foram analisados dez processos licitatórios do período entre 2013 e 2017, referentes a obras de edificações e infraestrutura (no casa da Universidade Federal de Tecnologia do Paraná - UTFPR) para entidades contratantes classificadas em diversas personalidades jurídicas dos poderes judiciário e executivo - além de uma entidade, o Parque de Inovação e Sustentabilidade do Ambiente Construído (PISAC), classificada atualmente como projeto de pesquisa dentro da Universidade de Brasília com intenções de se tornar uma Organização Social apresentadas e classificadas quanto a personalidade jurídica e a localidade no Quadro 05.

\begin{tabular}{|c|c|c|c|}
\hline \multicolumn{4}{|c|}{ Modalidade Tomada de Preços } \\
\hline Entidade & Sigla & Localidade (UF) & $\begin{array}{l}\text { Personalidade } \\
\text { Jurídica }\end{array}$ \\
\hline Câmara Municipal de Cotia & $\begin{array}{l}\text { CM- } \\
\text { Cotia }\end{array}$ & Cotia - SP & $\begin{array}{l}\text { Poder Legislativo } \\
\text { Municipal }\end{array}$ \\
\hline $\begin{array}{l}\text { Conselho Regional de Engenharia e } \\
\text { Agronomia do Paraná }\end{array}$ & $\begin{array}{l}\text { CREA- } \\
\text { PR }\end{array}$ & Cascavel - PR & Autarquia Estadual \\
\hline $\begin{array}{l}\text { Justiça Federal de Primeiro Grau em } \\
\text { Goiás }\end{array}$ & JF-GO & Rio Verde - GO & $\begin{array}{l}\text { Poder Judiciário } \\
\text { Federal }\end{array}$ \\
\hline $\begin{array}{l}\text { Justiça Federal de Primeiro Grau em } \\
\text { Minas Gerais }\end{array}$ & JF-MG & Divinópolis - MG & $\begin{array}{l}\text { Poder Judiciário } \\
\text { Federal }\end{array}$ \\
\hline $\begin{array}{l}\text { Centro de Pesquisa e Desenvolvimento } \\
\text { para Inovação e Sustentabilidade }\end{array}$ & CEPAC & Brasília - DF & $\begin{array}{l}\text { Projeto de Pesquisa } \\
\text { / Organização Social }\end{array}$ \\
\hline Tribunal Regional Eleitoral de Alagoas & TRE-AL & Maceió - AL & $\begin{array}{l}\text { Poder Judiciário } \\
\text { Federal }\end{array}$ \\
\hline Tribunal Regional Eleitoral da Paraíba & TRE-PB & Guarabira - PB & $\begin{array}{l}\text { Poder Judiciário } \\
\text { Federal }\end{array}$ \\
\hline Tribunal Regional Eleitoral de São Paulo & TRE-SP & $\begin{array}{l}\text { Parelheiros - SP / } \\
\text { Ponte Rasa - SP }\end{array}$ & $\begin{array}{l}\text { Poder Judiciário } \\
\text { Federal }\end{array}$ \\
\hline Universidade de São Paulo & USP & São Paulo - SP & Fundação Pública \\
\hline $\begin{array}{l}\text { Universidade Tecnológica Federal do } \\
\text { Paraná }\end{array}$ & UTFPR & Londrina - PR & Fundação Pública \\
\hline
\end{tabular}

Quadro 5: Lista de Entidades Contratantes - Modalidade Tomada de Preço. 
A avaliação dos processos da modalidade Tomada de Preços quanto ao nível de detalhamento de projeto - ou as etapas de projetos contempladas pela contratação permitiram verificar que todas as contratações abrangeram também todas as etapas de projeto, do estudo preliminar ao Projeto executivo.

Já no tocante às especialidades contratadas, verificou-se que todos os processos licitatórios optaram pela contratação unificada das diversas especialidades necessárias para a elaboração dos projetos técnicos das respectivas edificações, solicitando a entrega dos diversos projetos já compatibilizados.

Ainda relacionado à caracterização geral dos processos analisados na modalidade Tomada de Preços, quanto a categoria referente ao compartilhamento entre as especialidades, observou-se que em apenas três ocasiões não foram solicitados nenhum dos dois critérios referentes a essa categoria - a sugestão ou exigência pela utilização da Plataforma BIM e pela utilização de ferramenta, plataforma ou estratégia de compartilhamento de informações técnicas entre as especialidades. Os três casos anteriormente citados se referem aos processos de contratação da Câmara Municipal de Cotia, da UFTPR e da Justiça Federal de Minas Gerais.

Ainda em relação ao compartilhamento de informações, também foi observado que em outros quatro casos - CREA-PR, PISAC, TRE-SP e TRE-AL - foram solicitados os dois critérios e que nos três processos restantes - TRE-PB, JF-GO e USP - foram exigidos apenas o critério relacionado à utilização de ferramenta, plataforma ou estratégia de compartilhamento, sem, no entanto, especificar a utilização da Plataforma BIM.

\subsubsection{Avaliação dos aspectos técnicos - Modalidade Tomada de Preços}

A análise da categoria referente aos aspectos técnicos na modalidade Tomada de Preços indicou um equilíbrio na quantidade de resultados ruins ou insatisfatórios e resultados intermediários, sendo que 06 critérios apresentaram resultados negativos e 05 critérios foram classificados como resultados intermediários. Destaca-se ainda o fato de somente um critério dessa categoria apresentar um resultado classificado como positivo, conforme indicado no Gráfico 07.

Outro ponto a ser destacado é o fato de que dos 06 critérios que apresentaram resultados negativos, 04 não foram identificados em qualquer um dos 10 processos de licitação analisados na modalidade Tomada de preços, conforme detalhado nas análises individuais dos critérios desenvolvidas a seguir. 


\section{Aspectos Técnicos - Tomada de Preços}

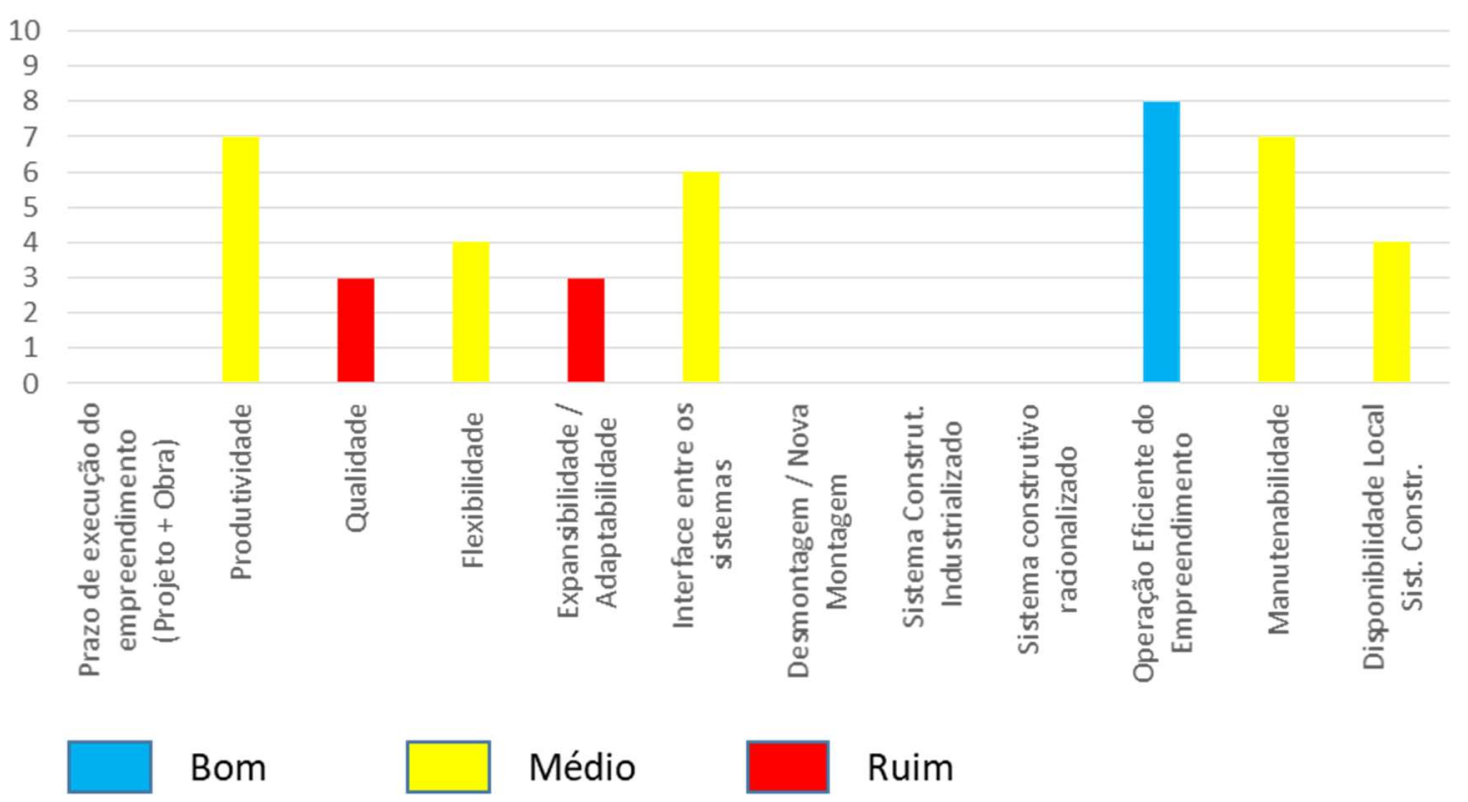

Gráfico 7: Resultados - Aspectos Técnicos / Modalidade Tomada de Preços.

a) Prazo de Execução

Diferentemente do que ocorreu nas modalidades anteriores, o critério que trata do prazo de execução de projeto como premissa de projeto não foi identificado nos processos de licitação da modalidade Tomada de Preços, tal como demonstrado pelo Gráfico 07, sendo considerado um resultado negativo pelos parâmetros adotados pela pesquisa.

b) Produtividade

A produtividade como premissa de projeto foi abordada em 07 processos licitatórios da modalidade Tomada de Preços, conforme a Gráfico 07, indicando a relevância do tema para as contratantes que adotaram a modalidade em questão, ainda que o resultado seja considerado intermediário. Esse resultado também ajuda a reafirmar os bons resultados obtidos pelo presente critério nas modalidades Concurso e Concorrência.

Já os achados de pesquisa, que retratam os fragmentos dos instrumentos licitatórios e estão sintetizados no quadro 01 do Apêndice $G$, demonstram a semelhança entre os textos adotados por diferentes entidades contratantes para abordar o mesmo tema, também baseados no Manual de Obras Públicas da SEAP.

Os achados também permitem observar que a questão da produtividade foi abordada tanto em função da facilidade na execução quanto pela exigência de atributos e requisitos presentes em sistemas construtivos industrializados, como a racionalização, a modulação e a padronização. 
c) Qualidade

O conceito de qualidade como premissa de projeto foi indicado 03 três processos da modalidade Tomada de Preços, repetindo o resultado da modalidade Concorrência, sendo também considerado um resultado ruim ou insatisfatório - conforme indicado na Gráfico 07.

Os fragmentos dos instrumentos de licitação onde foram identificados a presença da qualidade como premissa de projeto indicam que o tema em questão foi abordado tanto de forma mais abrangente - ao se referir ao padrão de qualidade como condição de especificação - quanto de forma mais específica - tratando da questão do acabamento superficial.

d) Flexibilidade

A flexibilidade de uso como premissa de projeto foi identificada em 04 processos de licitação dos 10 analisados na modalidade Tomada Preço, sendo esse resultado classificado como intermediário de acordo com os parâmetros adotados pela pesquisa, conforme indicado no Gráfico 07.

Os achados de pesquisa, situados no quadro 03 do Apêndice G, ilustram que a flexibilidade foi retratada pelas entidades contratantes tanto do ponto de vista operacional, ao facilitar as adaptações do espaço, quanto do ponto vista ambiental, a partir da questão da produção de resíduos.

e) Expansibilidade

A facilidade de expansão e a adaptação das estruturas como diretriz de projeto foi identificada em 03 processos de licitação dos 10 analisados na modalidade Tomada de Preço, indicando outro resultado ruim ou insatisfatório no tratamento dos aspectos técnicos de projeto e planejamento - conforme demonstrado pelo Gráfico 07.

Os achados de pesquisa do critério referentes à expansibilidade, localizados no quadro 04 do Apêndice $\mathrm{G}$, indicam a repetição da redação dos instrumentos licitatórios em diferentes processos. Destaca-se ainda que essa redação também tem como fonte primária o Manual de Obras Públicas da SEAP.

f) Interface entre os sistemas

A questão do tratamento das interfaces entre diferentes sistemas e componentes como diretriz de projeto foi identificada em 06 processos de licitação dos 10 analisados na modalidade Tomada de Preço, indicando mais um resultado regular na categoria em questão nessa modalidade - conforme demonstrado pelo Gráfico 07. 
Novamente, os achados de pesquisa do critério que tratam das soluções de interface, situados no quadro 04 do Apêndice $\mathrm{G}$, indicam a repetição da redação dos instrumentos licitatórios em diferentes processos. Destaca-se ainda que essa redação também tem como fonte primária o Manual de Obras Públicas da SEAP.

g) Desmontagem / Nova Montagem, Sistema Construtivo Industrializado e Sistema Construtivo Racionalizado

Os critérios que tratam dos temas referentes à Desmontagem e Remontagem, à utilização de Sistemas Construtivos Industrializados e Sistemas Racionalizados não foram identificados nos processos de licitação da modalidade Tomada de Preços, conforme ilustrado pelo Gráfico 07.

h) Operação Eficiente do Empreendimento

O critério que trata da operação eficiente do empreendimento público como diretriz de projeto foi identificado em 08 processos licitatórios dos 10 analisados, conforme indicado pelo Gráfico 07. Esse resultado corresponde ao único resultado positivo da categoria em questão.

Assim como ocorreu em critérios anteriores das modalidades Tomada de Preço e Concorrências, o presente critério foi retratado por entidades distintas com redações semelhantes, extraídas do Manual da SEAP - conforme indicado pelos achados de pesquisa, localizados no quadro 05 do Apêndice G.

i) Manutenção

A questão da manutenção foi abordada em 07 processos licitatórios da modalidade Tomada de preços, de acordo com o Gráfico 07, indicando uma certa relevância desse critério no processo de contratação de projetos, ainda que o resultado seja classificado pela pesquisa como regular.

Os achados de pesquisa do presente critério também indicam a repetição da abordagem da Manutenção por diferentes entidades contratantes, conforme indicado no quadro 06 do Apêndice G. Também é possível observar a maioria das abordagens do critério em questão foram retiradas do Manual de Obras Públicas da SEAP, tal como ocorreu em critérios e categorias anteriores.

j) Disponibilidade local dos sistemas

A disponibilidade local dos sistemas como premissa de projeto foi identificada em 04 processos licitatórios da modalidade Tomada de Preços, sendo esse resultado considerado regular pela presente pesquisa, independentemente de a sua avaliação se dar de maneira inversa, conforme já tratado pela pesquisa. 
5.2.3.2 Avaliação dos aspectos ambientais - Modalidade Tomada de Preços

A categoria referente aos aspectos ambientais da modalidade Tomada de Preço apresentou um equilíbrio na quantidade de resultados negativos e resultados regulares, conforme indicado pelo Gráfico 08. Também é possível observar que os resultados negativos ficaram a cargo dos critérios que tratam da reciclagem e da reutilização de materiais e componentes.

\section{Aspectos Técnicos - Tomada de Preços}
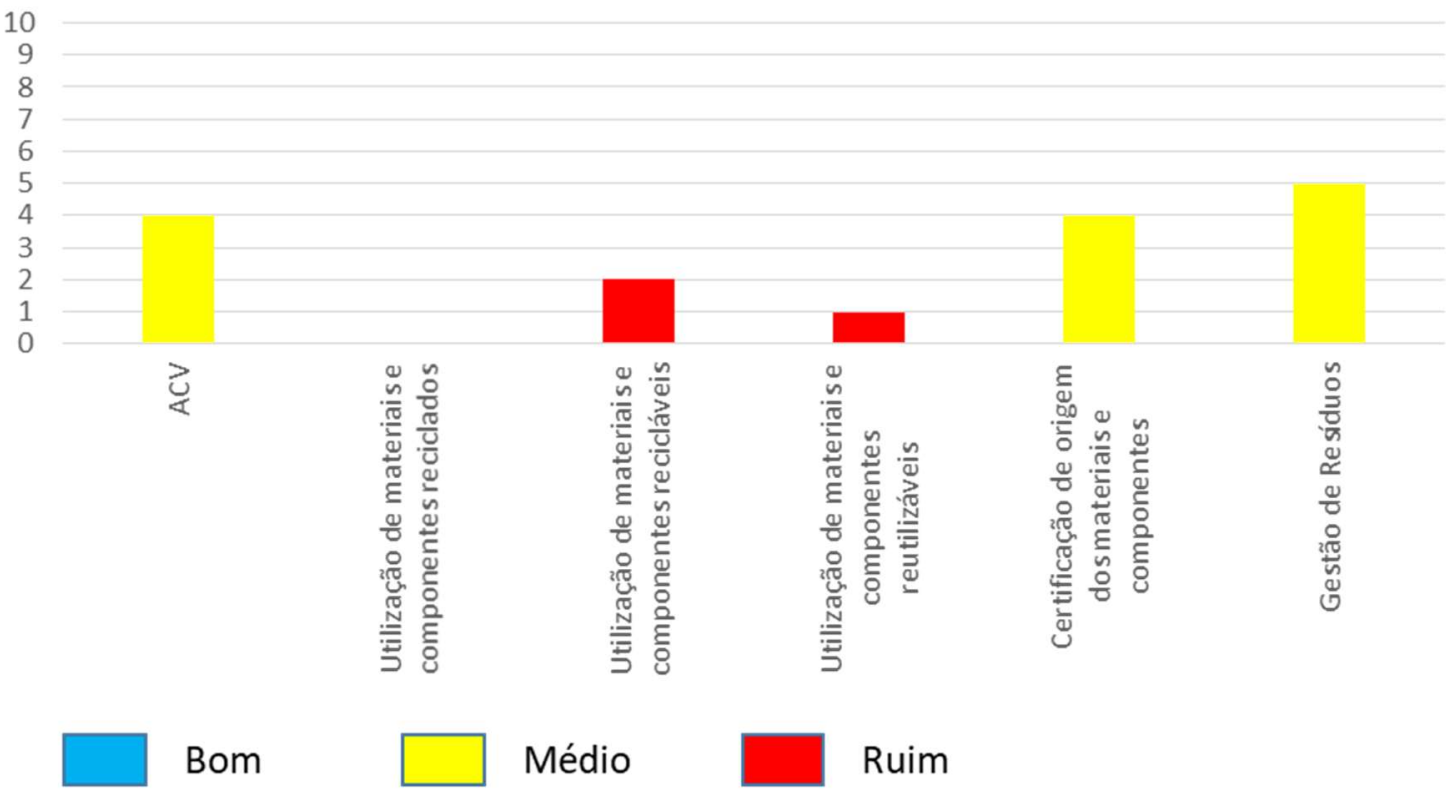

Gráfico 8: Resultados / Aspectos Técnicos - Modalidade Tomada de Preços

a) $\mathrm{ACV}$

O critério que trata da Avaliação do Ciclo de Vida dos sistemas construtivos e materiais como diretriz de projeto foi identificado em 04 processos licitatórios dos 10 analisados na modalidade Tomada de Preços, conforme indicado pelo Gráfico 08, o que significa um resultado regular.

Assim como ocorreu nas modalidades anteriores, a abordagem da ACV se deu maneira indireta, havendo apenas solicitações de que as soluções de projeto tenham em vista o desenvolvimento sustentável ao longo do Ciclo de Vida e contemplem a durabilidade dos materiais.

A repetição da redação sobre o tema por diferentes entidades contraentes também esteve presente na abordagem do presente critério na modalidade Tomada de Preços, tal como ocorreu em critérios anteriores, conforme indicado pelos achados de pesquisa localizados no quadro 01 do Apêndice $\mathrm{H}$. 
b) Utilização de Materiais e componentes reciclados

A utilização de sistemas construtivos constituídos de materiais e componentes reciclados não foi identificada nos processos licitatórios da modalidade Tomada de Preços, conforme indicado pelo Gráfico 08, indicando um resultado negativo.

c) Utilização de Materiais e componentes recicláveis

Já a categoria que trata da utilização de materiais e componentes passíveis de serem tratado pelo processo de reciclagem foi identificada em 02 processos dos 10 analisados na modalidade Tomada de Preços, indicando mais um resultado negativo quanto aos aspectos ambientais - conforme informado pelo Gráfico 08.

Os achados de pesquisa, localizados no quadro 02 do Apêndice $H$, demonstram que a abordagem do critério em questão pelas duas entidades que o adotou foi feita com a utilização do mesmo texto, assim como ocorreu em critérios anteriores. Destaca-se ainda que essa abordagem associou a reciclagem dos materiais com a sustentabilidade do empreendimento.

d) Utilização de Materiais e componentes reutilizáveis:

O que critério que trata da utilização de materiais e componentes que possam ser reutilizados como premissa de projeto foi identificado em apenas um processo de licitação, conforme indicado no Gráfico 08. Esse resultado é classificado como um resultado negativo e corrobora a pouca importância dada a esse critério durante o processo de planejamento da obra pública.

e) Certificação de origem dos materiais e componentes:

A certificação de origem dos materiais e componentes como requisito de projeto foi abordada em 04 processos da modalidade Tomada de Preços, conforme retratado pelo Gráfico 08; o que indica um desempenho regular desse critério.

f) Gestão de Resíduos:

A gestão de resíduos como diretriz de projeto foi identificada em 05 processos licitatórios dos 10 analisados pela modalidade Tomada de Preços, conforme o Gráfico 08, sendo este um resultado considerado regular de acordo parâmetros adotados pela presente pesquisa.

Quanto aos achados de pesquisa referentes ao critério em questão, sintetizados no quadro 05 do Apêndice 08, indicam uma diversidade maior na forma de abordar a questão do gerenciamento de resíduos, sendo ela abordada tanto a partir da ótica da geração e destinação dos resíduos quanto pela exigência da elaboração de um Programa de Gerenciamento de Resíduos. 
5.2.3.3 Avaliação dos aspectos Socioeconômicos - Modalidade Tomada de Preços

Os critérios que compõem os aspectos socioeconômicos do processo de planejamento das obras públicas obtiveram, por maioria, resultados intermediários ou regulares nos processos licitatórios da modalidade Tomada de Preços, conforme demonstrado pelo Gráfico 09. Sendo assim, apenas o critério que trata da utilização de mão de obra especializada como requisito de projeto apresentou resultado negativo, uma vez que não foi identificado nos processos da modalidade em questão.

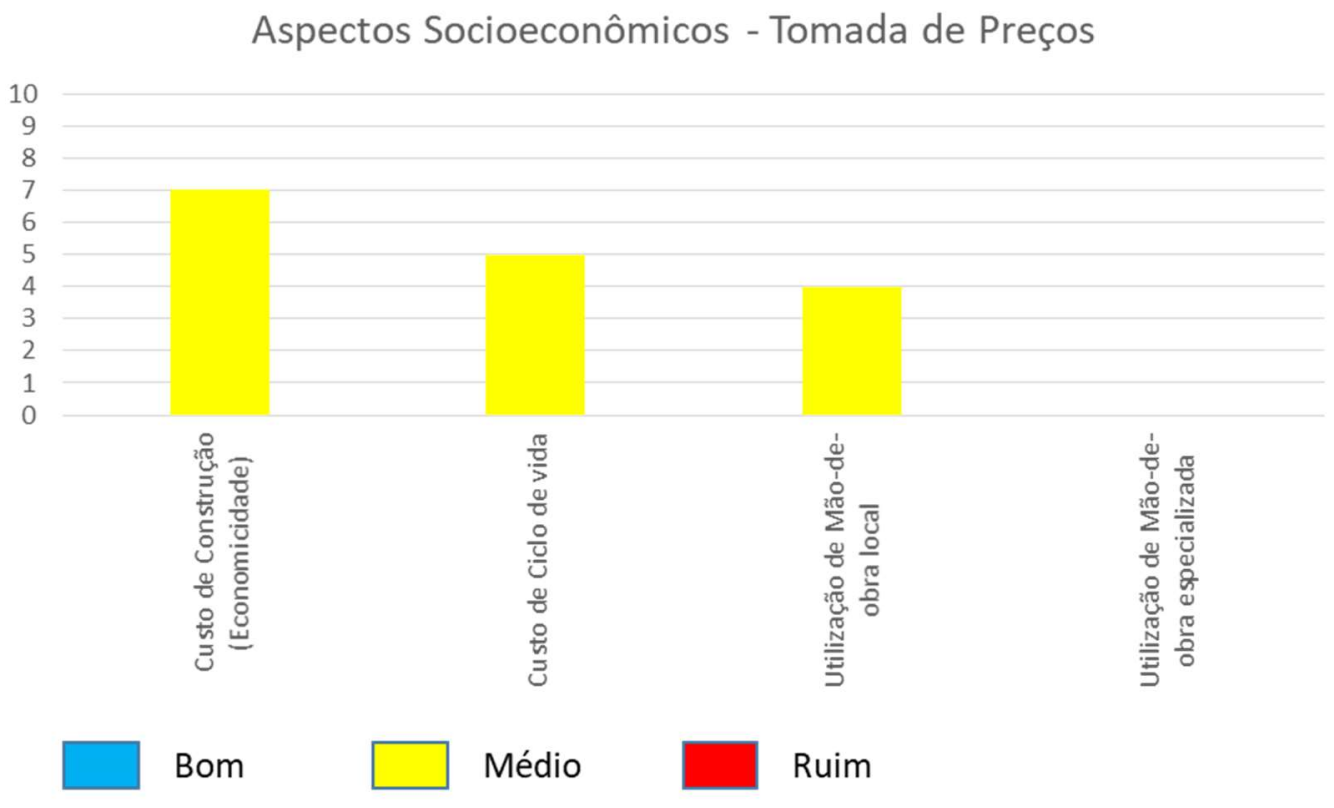

Gráfico 9: Resultados - Aspectos Socioeconômicos / Modalidade Tomada de Preços.

a) Custo de Construção (Economicidade)

A questão do custo de execução da obra pública esteve presente em 07 processos licitatórios da Modalidade Tomada de Preços, conforme o Gráfico 09; resultado que indica um desempenho regular, ainda que esteja presente na maioria dos processos da modalidade em questão.

Embora o resultado apresentado pelo critério em questão na modalidade Tomada de Preços seja classificado como intermediário ou regular, ele se manteve próximo dos resultados apresentados pelas modalidades anteriores, indicando um significativo apreço das entidades contratantes quanto à questão do custo de execução dos empreendimentos.

Assim como ocorreu na modalidade concorrência, os processos licitatórios da Modalidade Tomada de Preços são caracterizados por abordar a questão do custo ou da economicidade do empreendimento utilizando a mesma redação nos diferentes processos, tendo como base o Manual de Obras Públicas da SEAP - conforme indicado pelos achados de Pesquisa localizados no Quadro 01 do Apêndice I. 
b) Custo de Ciclo de Vida

O custo do empreendimento público ao longo do seu ciclo de vida foi considerado em 05 processos licitatórios da modalidade Tomada de Preços, tal como indicado pelo Gráfico 09; sendo este considerado um resultado regular de acordo com os parâmetros estipulados pela pesquisa.

Os achados de pesquisa, localizados no Quadro 02 do Apêndice I, indicam uma diversidade maior na redação da abordagem sobre o custo do ciclo vida, ainda que esse critério seja relacionado basicamente ao custo de conservação, operação e manutenção pelos instrumentos de licitação.

c) Utilização de mão de obra local

A exigência ou requisição do uso de mão de obra local como requisito de projeto foi identificado em 04 processos da modalidade Tomada de Preços, conforme o Gráfico 09; indicando um resultado intermediário ainda que ele deva ser analisado de maneira inversa, devido a possibilidade de agir como um entrave à especificação de sistemas construtivos industrializados nas soluções de projeto.

Os achados de pesquisa referentes ao presente critério, sintetizados no quadro 03 do Apêndice I, também indicam uma semelhança de abordagem, sendo que a redação utilizada também tem como texto base o Manual de Obras Públicas da SEAP.

d) Utilização de Mão de obra especializada

Conforme abordado anteriormente, o critério que trata da utilização de mão de obra especializada como diretriz para a elaboração dos projetos técnicos não foi identificado nos instrumentos de licitação da modalidade Tomada de Preços. Esse resultado reafirma a inobservância, por parte das entidades contratantes, do papel que a administração pública tem em emular uma transformação na qualidade da mão de obra disponível na Indústria da Construção.

\subsubsection{Modalidade Convite}

Para avaliar a modalidade Tomada de Preços, foram analisados dez processos licitatórios do período entre 2012 e 2017, referentes a obras de edificações para entidades administrativas com personalidades jurídicas pertencentes aos poderes legislativo e executivo - Câmaras Municipais de Canitar e Venda Nova e fundações Públicas - além de autarquias sui generis, conselhos profissionais, conforme exposto no Quadro 06. 
Modalidade Convite

\begin{tabular}{|c|c|c|c|}
\hline Entidade & Sigla & Localidade (UF) & $\begin{array}{l}\text { Personalidade } \\
\text { Jurídica }\end{array}$ \\
\hline $\begin{array}{l}\text { Conselho Federal de Fonoaudiologia da } \\
\text { 8a região }\end{array}$ & CFF8 & Fortaleza - CE & $\begin{array}{l}\text { Autarquia Sui } \\
\text { generis }\end{array}$ \\
\hline Câmara Municipal de Canitar & CM - Canitar & Canitar - SP & $\begin{array}{l}\text { Poder Legislativo } \\
\text { Municipal }\end{array}$ \\
\hline $\begin{array}{l}\text { Câmara Municipal de Venda Nova do } \\
\text { Imigrante }\end{array}$ & $\begin{array}{l}\text { CM - Venda } \\
\text { Nova }\end{array}$ & $\begin{array}{l}\text { Venda Nova do } \\
\text { Imigrante - ES }\end{array}$ & $\begin{array}{l}\text { Poder Legislativo } \\
\text { Municipal }\end{array}$ \\
\hline $\begin{array}{l}\text { Conselho Regional de Corretores } \\
\text { Imobiliários do Estado de Minas Gerais }\end{array}$ & $\mathrm{CRECl}-\mathrm{MG}$ & Belo Horizonte & $\begin{array}{l}\text { Autarquia Sui } \\
\text { generis }\end{array}$ \\
\hline $\begin{array}{l}\text { Conselho Regional de Educação Física } \\
\text { da 9ạ Região - Estado do Paraná }\end{array}$ & CREF9 & Curitiba - PR & $\begin{array}{l}\text { Autarquia Sui } \\
\text { generis }\end{array}$ \\
\hline $\begin{array}{l}\text { Conselho Regional de Farmácia do } \\
\text { Estado de Goiás }\end{array}$ & CRF - GO & Goiânia - GO & $\begin{array}{l}\text { Autarquia Sui } \\
\text { generis }\end{array}$ \\
\hline $\begin{array}{l}\text { Conselho Regional de Farmácia do } \\
\text { Estado de Pernambuco }\end{array}$ & CRF - PE & Recife - PE & $\begin{array}{l}\text { Autarquia Sui } \\
\text { generis }\end{array}$ \\
\hline $\begin{array}{l}\text { Conselho Regional de Psicologia da 17ạa } \\
\text { Região }\end{array}$ & CRP - RN & Natal - RN & $\begin{array}{l}\text { Autarquia Sui } \\
\text { generis }\end{array}$ \\
\hline $\begin{array}{l}\text { Fundação de Amparo à Pesquisa do } \\
\text { Estado de São Paulo }\end{array}$ & FAPESP & São Paulo - SP & Fundação Pública \\
\hline $\begin{array}{l}\text { Fundação Diamantinense de Apoio ao } \\
\text { Ensino, Pesquisa e Extensão }\end{array}$ & FUNDAEPE & Diamantina - SP & Fundação Pública \\
\hline
\end{tabular}

Quadro 6: Lista de Entidades Contratantes - Modalidade Convite

Os processos licitatórios da modalidade Convite, quanto ao nível de detalhamento de projeto, contemplaram todas as etapas de projeto - do Estudo Preliminar ao Projeto Executivo. Quanto às especialidades técnicas contratadas, todas as licitações optaram pela contratação de projetos integrados, com unificação da contratação das diversas especialidades.

No que se trata da categoria referente ao compartilhamento de informações entre as especialidades, não foi identificado a presença dos critérios que compõem essa categoria - Utilização da Plataforma Bim e utilização de ferramenta, plataforma ou estratégia de compartilhamento de informações técnicas - nos processos da modalidade Convite.

Diferentemente das modalidades anteriores, a análise da modalidade Convite será restrita aos critérios que foram contemplados pelos processos licitatórios, tendo em vista a objetividade da apresentação dos resultados e do andamento da pesquisa.

\subsubsection{Avaliação dos aspectos técnicos - Modalidade Convite}

A categoria que trata dos aspectos técnicos de planejamento na modalidade Convite é caracterizada pela predominância da ausência dos critérios que a compõem nos processos de licitação dessa modalidade, conforme indicado pelo Gráfico 10. Observa-se 
também que os poucos critérios dessa categoria contemplados pelos processos licitatórios também obtiveram resultados negativos.

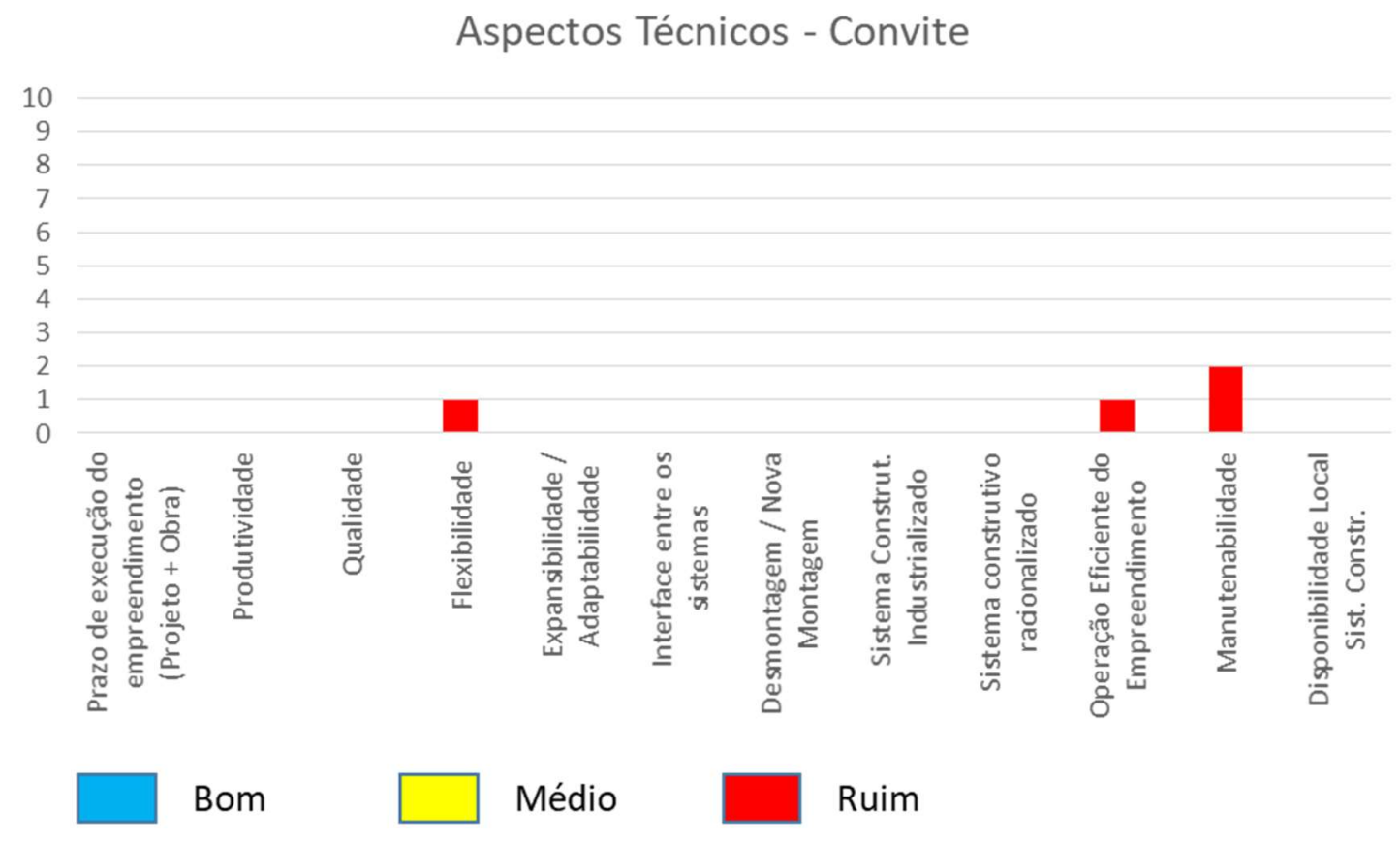

Gráfico 10: Resultado / Aspectos Técnicos - Modalidade Convite.

Conforme tratado anteriormente, a única ausência que pode ser considerada positiva é a que se refere ao critério que trata da disponibilidade local dos sistemas construtivos como diretriz ou premissa de projeto, uma vez que esse critério pode ser considerado um possível entrave à utilização dos sistemas construtivos industrializado e, por isso, deve ser analisado de maneira inversa.

a) Flexibilidade

O critério que trata da flexibilidade como premissa de projeto foi identificado em apenas um processo de licitação, conforme indicado no Gráfico 10. A classificação adotada pela pesquisa considera esse resultado negativo, sendo necessário destacar que a modalidade Convite é a primeira que apresenta um resultado negativo nesse critério.

b) Operação Eficiente do Empreendimento

A operação eficiente do empreendimento também foi considerada por apenas um processo licitatório, conforme o Gráfico 10, sendo esse resultado considerado igualmente negativo. O resultado apresentado pela modalidade convite também foi o pior dentre as modalidades de licitação analisadas pela pesquisa.

c) Manutenção 
$\mathrm{O}$ critério referente à manutenção do empreendimento esteve presente em dois processos licitatórios da modalidade Convite, conforme indicado no Gráfico 10, o que se configura como mais um resultado negativo da categoria em questão nessa modalidade. Esse resultado também é o primeiro resultado negativo dentre as modalidades analisados pela pesquisa, além de ser configurado por uma grande diferença em comparação aos resultados das outras modalidades, que apresentaram resultados bastante superiores.

5.2.4.2 Avaliação dos aspectos ambientais - Modalidade Convite

Os critérios que abordam os aspectos ambientais do processo de planejamento das obras públicas não foram identificados nos processos de licitação da Modalidade, sendo esse o pior resultado dentre todas as modalidades analisadas pela presente pesquisa.

\subsubsection{Avaliação dos aspectos socioeconômicos - Modalidade Convite}

A categoria referente aos aspectos socioeconômicos de planejamento na modalidade Convite é caracterizada por contemplar somente os critérios referentes ao custo, custo de execução e custo de ciclo de vida, conforme indicado pelo Gráfico 11 . Dessa forma, os critérios que tratam da mão de obra não foram contemplados pelos processos licitatórios dessa modalidade.

\section{Aspectos Socioeconômicos - Convite}

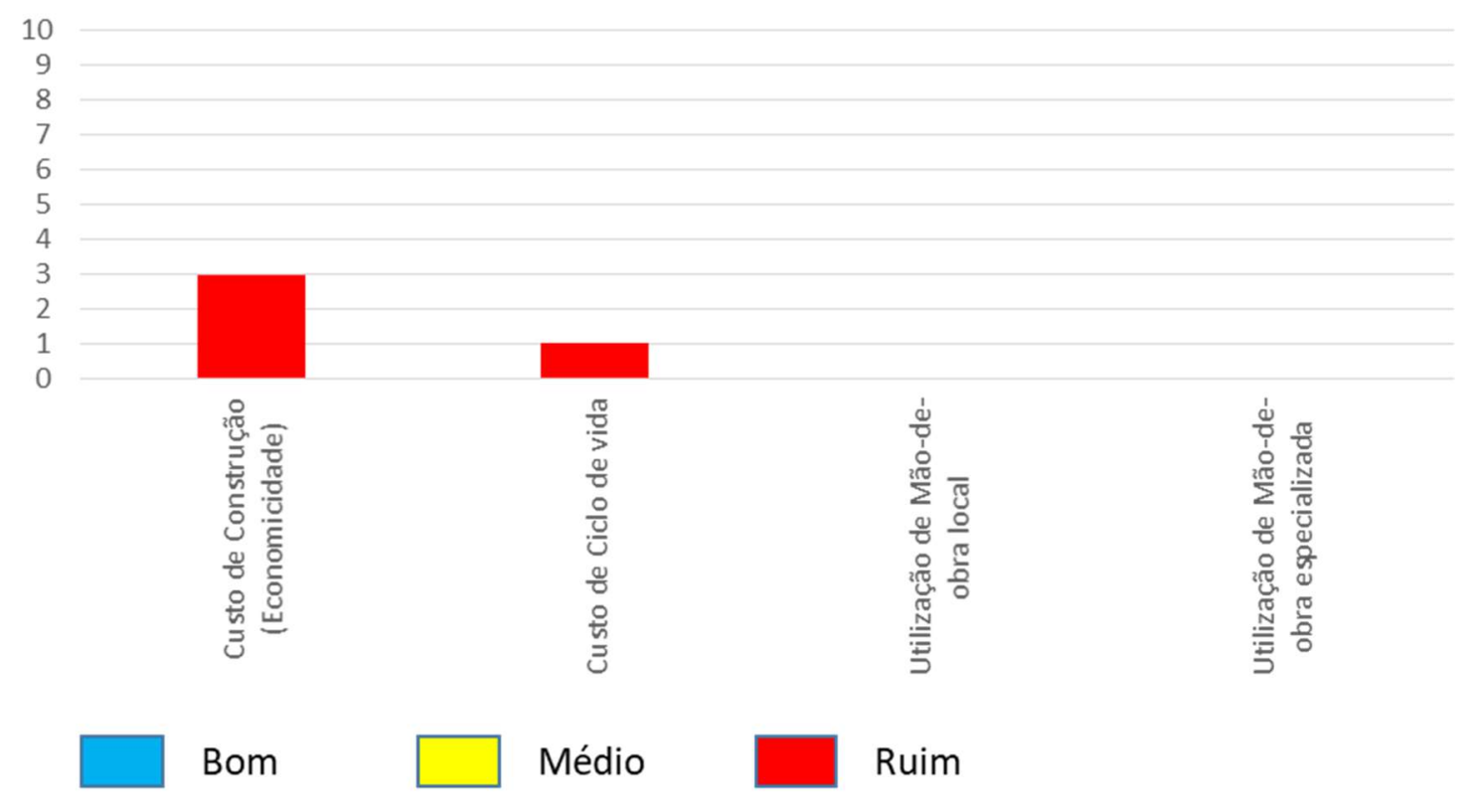

Gráfico 11: Resultados / Aspectos Socioeconômicos - Modalidade Convite

a) Custo de Construção (economicidade)

O critério referente ao custo de execução da obra pública foi identificado em 03 processos licitatórios da modalidade Convite, conforme indicado no Gráfico 11, sendo 
ele considerado negativo. Vale destacar que o resultado apresentado pela modalidade Convite foi o único resultado negativo dentre as modalidades consideradas pela pesquisa.

b) Custo de Ciclo de Vida

Já o custo de ciclo de vida da edificação pública foi considerado em apenas um processo licitatório, conforme o Gráfico 11. Esse resultado é classificado como negativo ou insatisfatório, sendo ele o primeiro resultado com essa classificação entre as modalidades analisadas pesquisa e, por consequência, o pior.

c) Utilização de mão de obra local e utilização de mão de obra especializada

Conforme citado anteriormente, os critérios referentes à utilização da mão de obra como diretriz de projeto não foram contemplados pelos processos licitatórios da modalidade Convite, assim como ocorreu na modalidade Concurso.

No entanto, somente a ausência do critério que trata da utilização de mão de obra especializada pode ser considerada negativo, uma vez que solicitação da utilização de mão de obra local pode ser entendido como um entrave à utilização de sistemas construtivos industrializados como solução de projeto e, portanto, sua análise deve ser realizada de maneira inversa.

\subsubsection{Comparativo entre as modalidades}

A comparação entre os resultados das modalidades tem como objetivo principal obter um panorama do quanto os critérios determinantes na escolha dos sistemas construtivos industrializados são considerados nos processos licitatórios, sem a intenção de eleger uma modalidade ideal.

\subsubsection{Comparativo na Categoria Avaliação dos Aspectos Técnicos}

A intensidade geral da presença dos critérios referentes aspectos técnicos nos processos de licitação é representada pela média dos resultados apresentados pelas modalidades analisadas e pelo desvio padrão apontado pela diferença entre esses resultados, a fim de garantir maior fidelidade da análise à realidade encontrada.

De acordo com as informações demonstradas pelo Gráfico 12, os resultados apresentados pelos critérios da categoria referente aos aspectos técnicos oscilam entre resultados negativos e intermediários com picos de resultados positivos nos critérios que tratam da produtividade, flexibilidade, operação e manutenção. 


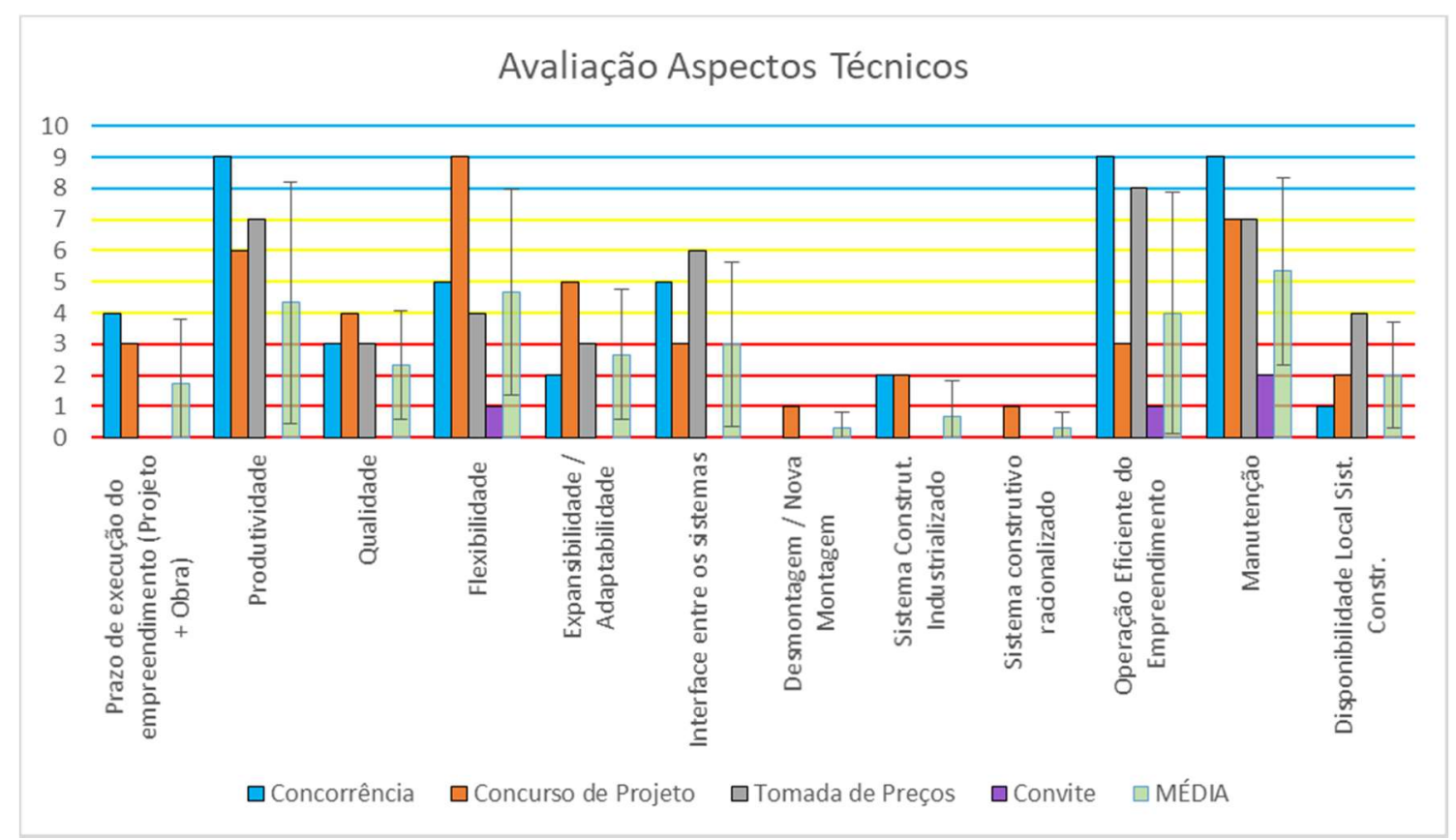

Gráfico 12: Comparativo entre modalidades / Avaliação Aspectos Técnicos.

Já a média dos resultados dos critérios avaliados se restringem a resultados negativos e intermediários; sendo que a redução dos valores da média pode ser atribuída principalmente ao baixo desempenho da modalidade convite, que em muitos critérios teve resultado nulo e nos poucos critérios contemplados os resultados foram sempre negativos.

O baixo desempenho da modalidade Convite na avaliação dos aspectos técnicos teve como consequência o aumento da disparidade entre os resultados das diversas modalidades nos diferentes critérios, caracterizando uma heterogeneidade dos dados obtidos, o que reflete na grande amplitude do desvio padrão da maioria dos critérios. Esse fato pode ser observado principalmente nos critérios referentes à Produtividade, à Flexibilidade, à Operação e à Manutenção.

A comparação entre as modalidades também permite identificar que os critérios relacionados à produtividade e à manutenção do empreendimento são os que apresentaram melhores resultados nas modalidades Concurso, Concorrência e Tomada de Preços, indicando que as entidades já identificam a importância desses critérios no processo de planejamento.

O comparativo também permite identificar que a solicitação expressa pela utilização de sistemas construtivos industrializados ou racionalizados ainda é realizada de forma incipiente, sendo que os achados de pesquisa indicam que a abordagem sobre essa questão ainda é feita de forma indireta na maioria dos casos, ao adotar nomenclaturas alternativas como "sistemas modernos" ou "novas tecnologias" para se referir aos SCI's. 


\subsubsection{Comparativo na Categoria Avaliação dos Aspectos Ambientais}

Os critérios que tratam dos aspectos ambientais foram retratados com a predominância de resultados negativos nos processos licitatórios analisados das diferentes modalidades, sendo que somente o critério referente à gestão de resíduos obteve média classificada como resultado regular, conforme indicado pelo Gráfico 13.

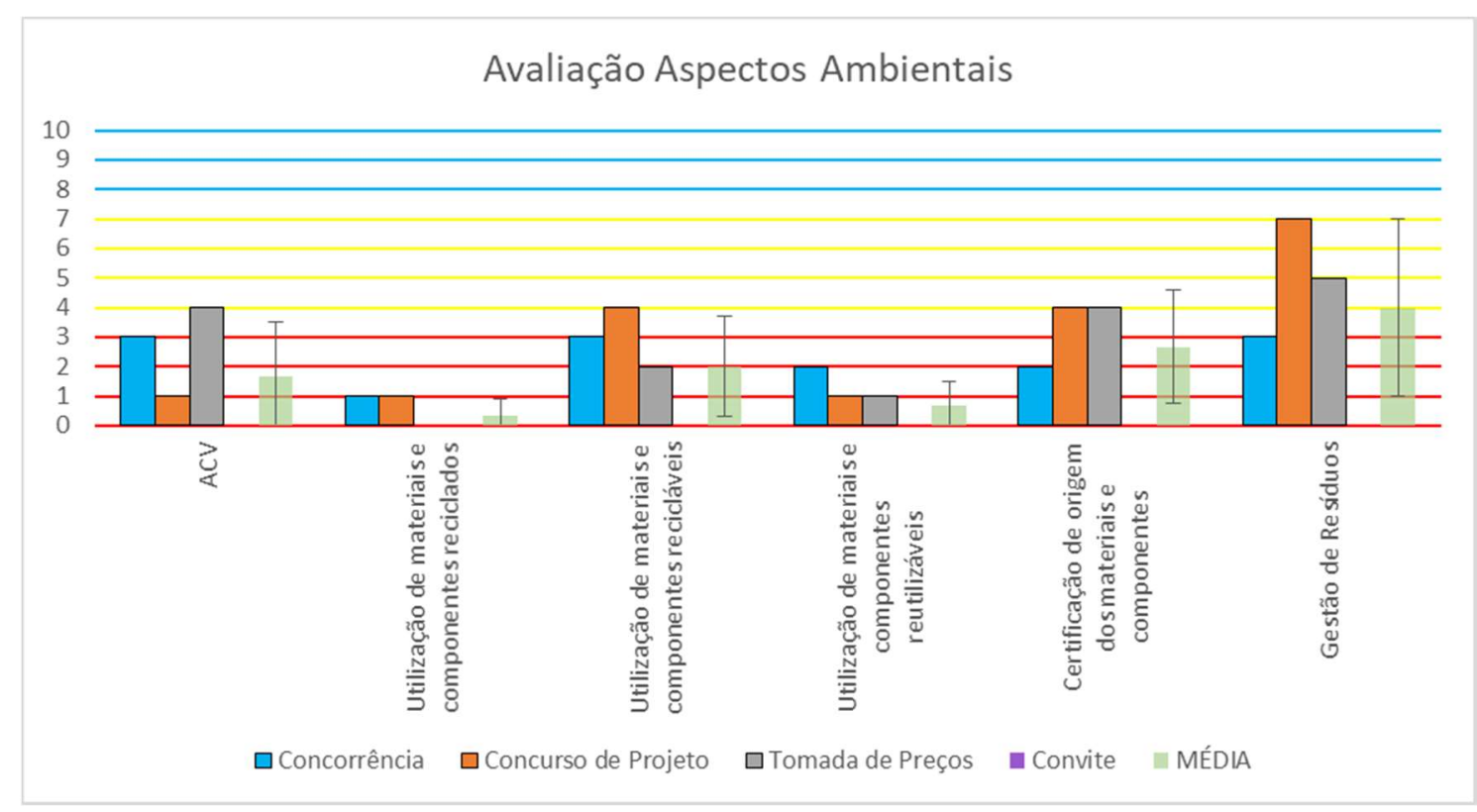

Gráfico 13: Comparativo entre modalidades / Avaliação Aspectos Ambientais.

Os resultados das modalidades Concurso, Concorrência e Tomada de Preços oscilaram entre resultados negativos e regulares, porém a média dos resultados permaneceu negativo, com exceção do critério referente aos resíduos sólidos - que obteve média regular. Esse panorama pode ser justificado também pelo fato de a modalidade convite não considerar os critérios que tratam dos aspectos ambientais.

Assim como ocorreu na avaliação dos aspectos técnicos, também é possível identificar a heterogeneidade dos resultados apresentados pelas modalidades analisadas quanto à presença dos critérios ambientais, sendo ela acentuada pela ausência desses critérios na modalidade convite.

\subsubsection{Comparativo na Categoria Avaliação dos Aspectos Ambientais}

Já os critérios referentes aos aspectos socioeconômicos podem ser divididos em dois grupos, o grupo que trata do custo e o que trata da questão da mão de obra, sendo que os resultados indicam um decrescimento progressivo na importância atribuída a esses critérios pelas entidades contratantes nas diferentes modalidades, conforme o Gráfico 14. 


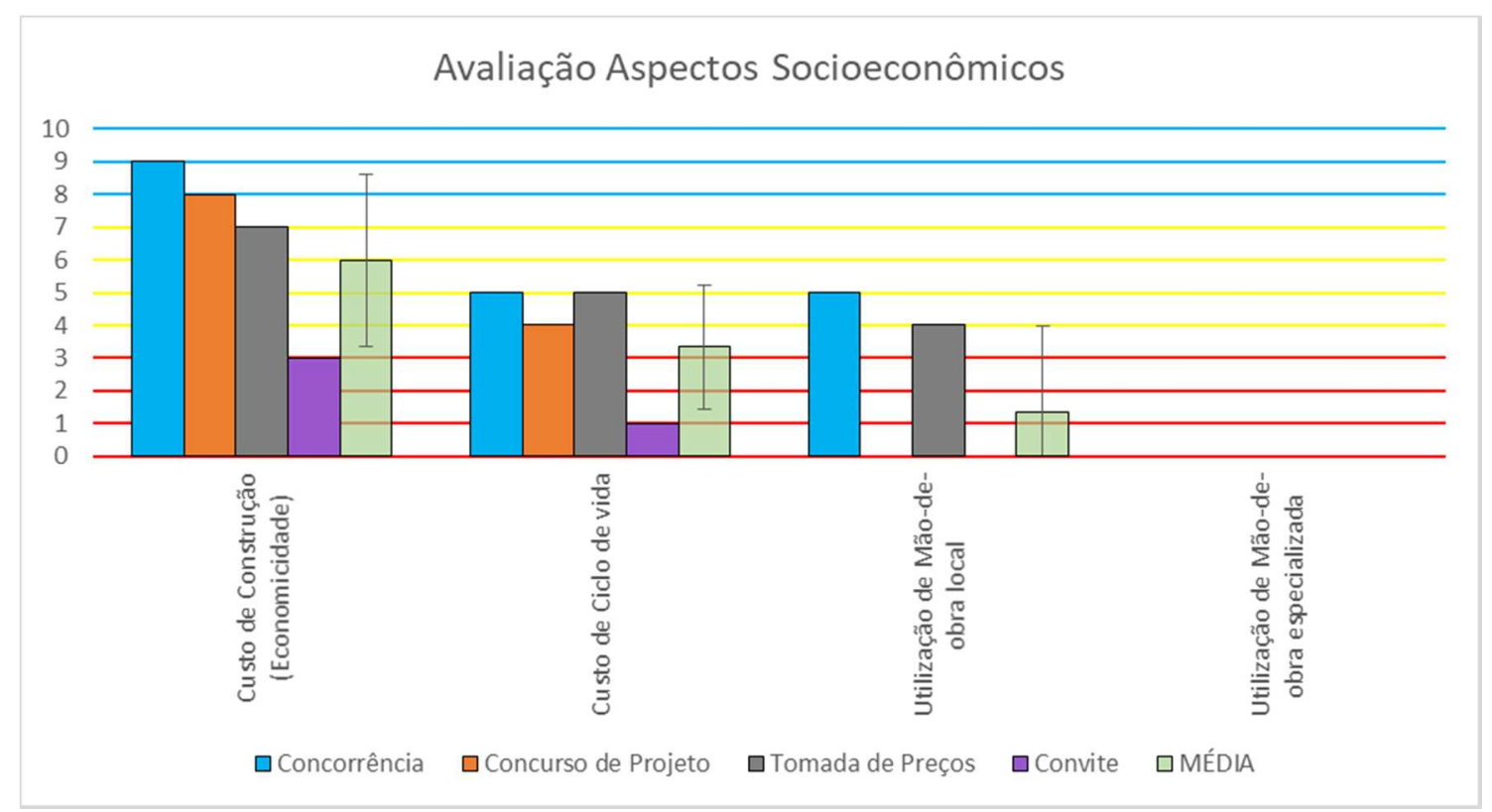

Gráfico 14: Comparativos entre modalidades / Avaliação Aspectos Socioeconômicos.

Ao analisar os dados apresentados pelo Gráfico 14, é possível observar que os critérios que tratam do custo obtiveram média classificada como intermediária ou regular, sendo que o critério que trata da economicidade no custo de execução apresentou resultados positivos nas modalidades Concurso e Concorrência e um resultado classificado como intermediário, porém expressivo, na modalidade Tomada de Preços.

Os critérios que tratam da utilização da mão de obra local obtiveram, por média, um resultado negativo, o que deve ser visto como positivo devido a possibilidade de o mesmo agir como um possível entrave à utilização dos sistemas industrializados; porém, esse critério obteve resultado regular nas modalidades Concorrência e Tomada de Preços.

Outro ponto a ser destacado é o fato do critério referente à utilização de mão de obra especializada não ter sido considerado em todas as modalidades analisadas, corroborando a ideia de que a administração pública não desempenha o papel indutivo na promoção da qualificação da mão de obra.

Assim como ocorreu nas categorias anteriores, as médias dos resultados apresentados foram reduzidas pelo desempenho da categoria Convite, que apresentou resultados negativos em todos os critérios, sendo que a baixa incidência dos critérios que tratam da mão de obra foi intensificada pelo desempenho da modalidade Concurso, influenciando também na heterogeneidade dos dados, conforme indicado pelo desvio padrão representado na Figura 14. 


\subsubsection{Avaliação dos resultados por tipo}

Outra forma de analisar os resultados é a partir do filtro por tipo de licitação, que consiste no critério de avaliação adotado pelas entidades contratantes para a escolha do prestador de serviço; sendo que o tipo Melhor Técnica corresponde aos 10 processos da Modalidade Concurso, o tipo Técnica e Preço é composto por 07 processos da modalidade Concorrência e 06 da Modalidade Tomada de Preços, total de 13 processos, e o tipo Menor Preço é composto por 10 processos da modalidade Convite, 04 da modalidade Tomada de Preços e 03 da modalidade Concorrência, totalizando 17 processos.

Porém, alguns pontos importantes devem ser considerados a fim viabilizar essa análise, como o fato de a amostragem por tipo ser considerada heterogênea - já que a quantidade de processos dos diferentes tipos é diferente, sendo necessário equalizar as amostragens por meio da utilização de porcentagem.

Outro ponto importante a ser destacado são os desequilíbrios identificados devido a todos os processos da modalidade Convite serem do tipo Menor Preço e os processos da modalidade Concurso terem como critério de avaliação a melhor proposta técnica, ainda que a Lei 8.666/03 não o classifique como do tipo melhor técnica, sendo primeiro mais grave, uma vez que os resultados da modalidade Convite foram todos negativos.

Ao comparar o Gráfico 15, que representa os resultados de todos os critérios por tipo, com o Gráfico 16, que trata da avaliação dos mesmos critérios por modalidade, é possível identificar um comportamento similar entre as médias, ainda que o comportamento das modalidades e dos tipos (individualmente) sejam diferentes.

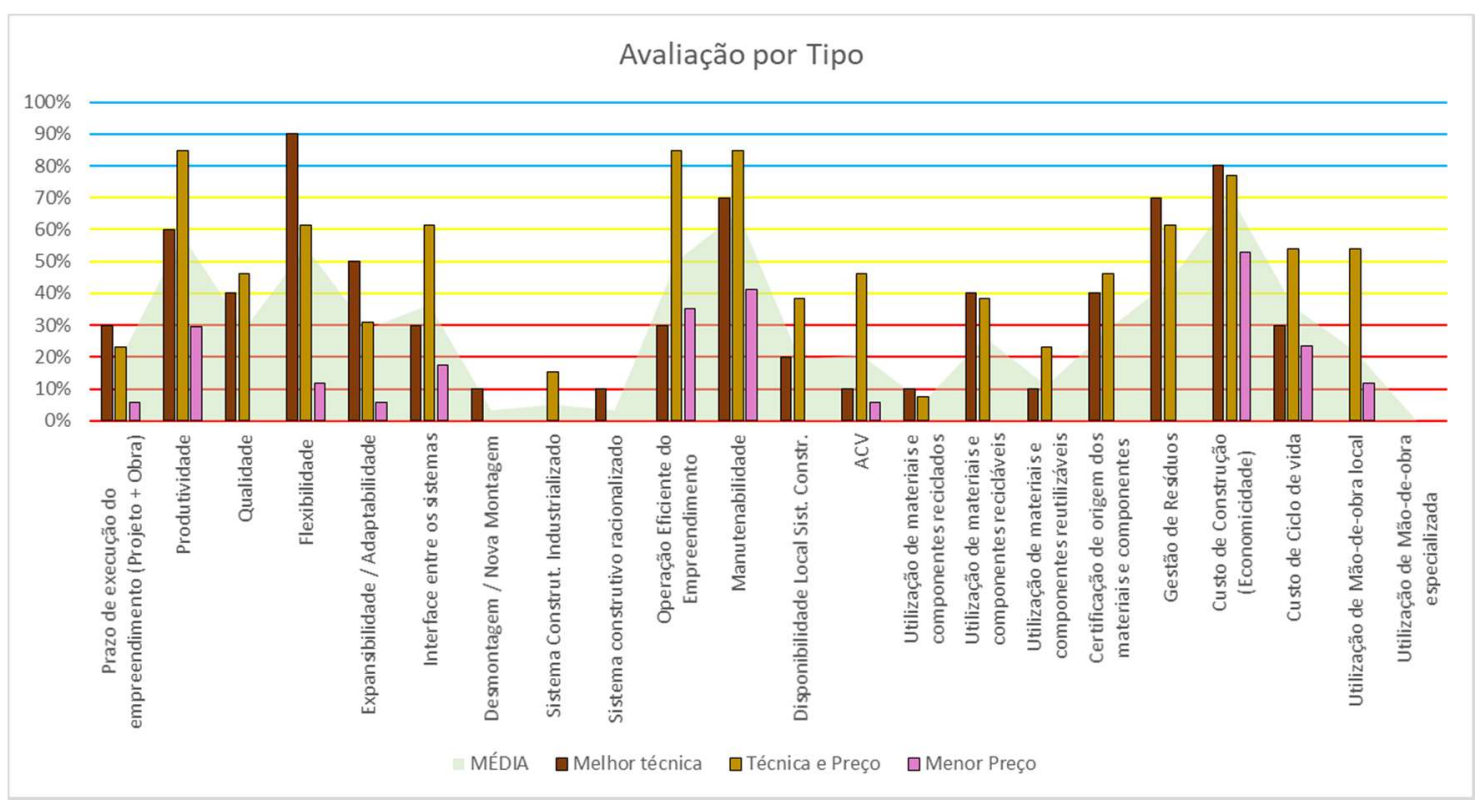

Gráfico 15: Panorama dos Resultados por Tipo 


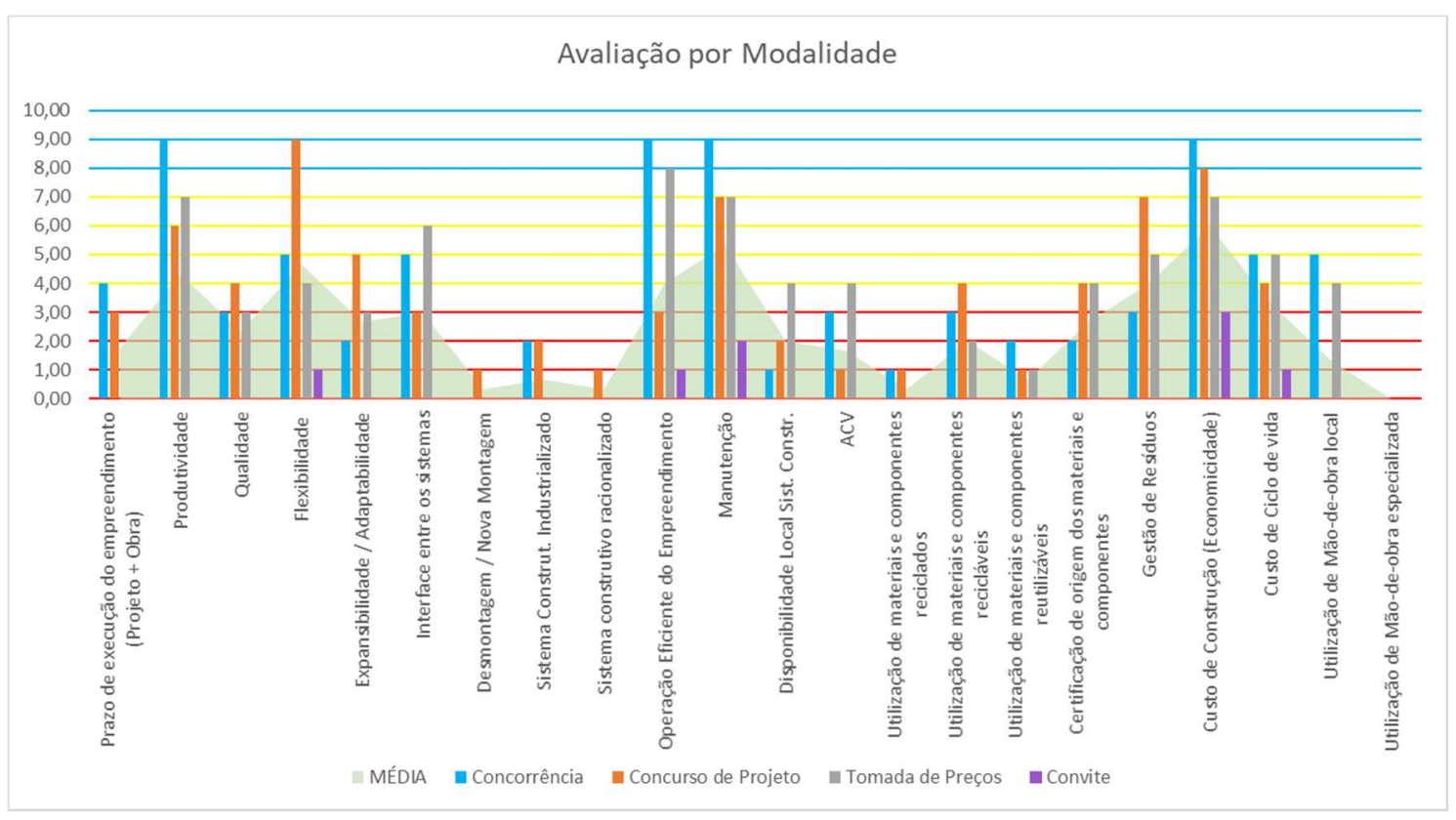

Gráfico 16: Panorama dos Resultados por Modalidade.

Também é possível observar que o comportamento apresentado pelo tipo Técnica e Preço acompanha o comportamento da Modalidade Tomada de Preços, assim como o tipo Menor Preço tende a acompanhar o comportamento da Modalidade Convite. Esses comportamentos são justificados pela predominância das respectivas modalidades nos respectivos tipos.

Porém há de ser observado o fato de a modalidade Convite apresentar uma restrição de valor muito grande quando comparada com as demais, imposta pela Lei 8.666/93, sendo possível a sua utilização em contratações com valor máximo de R \$ 150.000,00, enquanto que a modalidade Tomada de Preços possui um teto de $\mathrm{R} \$ 1.500 .000,00$ e as modalidades Concorrência e Concurso não apresentarem restrição de valor; o que tende a restringir o uso da modalidade Convite a serviços de menor tamanho e complexidade.

Dessa forma, é possível concluir que a complexidade dos serviços possui influência direta no nível de abordagem dos critérios relacionados à tomada de decisão quanto à utilização dos sistemas construtivos industrializados, embora não seja possível fazer a mesma conclusão quanto ao impacto tipo de licitação nesse processo devido aos desequilíbrios apontados pela pesquisa.

Outro ponto a ser destacado é a ausência de 11 critérios de avaliação nos processos de licitação do tipo Menor Preço, ou seja, metade dos critérios analisados. O que indica a inadequação da utilização do custo da prestação dos serviços como único critério a ser adotado no processo de contratação pública. 
Ainda é possível observar a baixa incidência dos critérios que tratam dos aspectos ambientais de maneira geral, tanto na avaliação por tipo quanto por modalidade. Da mesma forma, os critérios que abordam as questões referentes à mão de obra, local ou especializada, apresentaram baixa incidência nas amostragens analisadas, embora a baixa incidência do critério referente à utilização de mão de obra local seja positiva.

\subsection{Diagnóstico}

A aplicação da ferramenta de pesquisa proposta pelo trabalho para análise dos processos de licitação identificou que a presença desses fatores nas contratações públicas ocorreu de forma diversificada, com prevalência de resultados regulares e insatisfatórios, sendo que poucos fatores tiveram presença consistente nesses processos - exemplo da produtividade, da manutenção e do custo de construção.

Porém, os resultados obtidos pela pesquisa revelam que, mesmo quando presentes, as abordagens desses fatores como critérios de contratação são realizadas de maneira abrangente, pouco aprofundada e com pouca reflexão sobre a aplicação desses critérios na realidade da entidade contratante, do empreendimento e do seu usuário.

Essa abordagem abrangente e superficial e a pouca reflexão sobre a aplicação desses fatores na obra objeto do contrato são evidenciadas na repetição da abordagem de vários desses critérios por entidades diferentes nas modalidades Concorrência e Tomada de Preços, principalmente, inclusive do texto - tendo como fonte principal o Manual da SEAP, bem como na modalidade concurso, ainda que em menor intensidade.

A semelhança de abordagem identificada em alguns critérios e processos da modalidade concurso pode ser atribuída ao fato de a organização dos concursos de projeto ficarem sob a responsabilidade de diretórios do Instituto de Arquitetos do Brasil (IAB), tanto o Diretório Nacional quanto Diretórios estaduais, o que induz a uma certa da padronização dos instrumentos licitatórios elaborados por essas entidades.

A elaboração dos termos da contratação pelos diretórios do IAB, que são contratados para a execução desses serviços, implica em uma delegação da condução dessa contratação para essa entidade; o que, de certa forma, pode reduzir a interação entre contratante e contratada durante o processo de licitação nessa modalidade, já que a abordagem dos critérios é realizada por um intermediário, no caso os diretórios do IAB.

Um outro fator que pode ser associado às repetições de abordagem é a análise de mais de um processo licitatório de uma mesma entidade, como ocorreu na modalidade concurso nas contratações realizadas pela CODHAB; ou de entidades semelhantes, tais 
como as contratações da Justiça Federal de Goiás e Minas Gerais na modalidade Tomada de Preços, que também se mostraram bastante semelhantes.

Alguns critérios de avaliação chamaram atenção pelo baixo desempenho, a exemplo dos que compõem a categoria referente aos aspectos ambientais, principalmente os que tratam da reciclagem e da reutilização de componentes e materiais; e os que tratam da utilização da mão de obra especializada, sendo este ausente em todos os processos analisados pela pesquisa.

Outro aspecto identificado na aplicação da ferramenta nos estudos de caso é o que trata da falta de associação entre critérios que possuem relação direta. Um exemplo é a dissociação existente entre os critérios referentes à produtividade e ao prazo, onde o aumento do primeiro tende a reduzir a duração do segundo, porém esses critérios apresentaram resultados diferentes e com certa discrepância em todas as modalidades.

Os critérios que tratam da operação, manutenção e custo de ciclo de vida também apresentaram a dissociação identificada pelo parágrafo anterior, uma vez que os primeiros critérios apresentaram resultados superiores ao último, o que leva a compreender que os aspectos econômicos da operação e da manutenção do empreendimento nem sempre são considerados, ainda que as questões funcionais o sejam.

Os resultados auferidos pela pesquisa mostram o baixo desempenho dos critérios que tratam da solicitação expressa pela adoção de Sistemas construtivos industrializados e de sistemas construtivos racionalizados. Esses resultados indicam a ausência ou baixa incidência da indicação direta pela utilização de sistemas como solução de projeto.

As avaliações realizadas por este capítulo também indicam um agravamento do baixo desempenho dos fatores relacionados aos sistemas construtivos industrializados em função da complexidade dos serviços a serem contratados, uma vez que quanto mais simples o serviço contratado e de menor valor, menor é a incidência desses fatores durante o processo de planejamento preliminar e na contratação dos projetos.

Diante do exposto observa-se que os resultados revelam tanto um problema de intensidade da presença dos critérios, quanto de qualidade e modo de abordar esses critérios, dada a falta de reflexão mais apurada dos critérios e a dissociação entre os critérios conexos, deflagrando tanto uma deficiência de quantidade quanto de qualidade.

\subsection{Diretrizes}

Os resultados e as reflexões apresentadas pela pesquisa indicam que, de modo geral, o tema da construção industrializada não é abordado de maneira satisfatória pelo poder 
público na condição de contratante de serviços técnicos voltados para execução de obras, o que indica a abstenção da Administração pública do seu papel de agente catalisador no processo de inovação CPIC.

A fim de garantir a atuação do Estado como agente de inovação da indústria da construção, a pesquisa propõe as seguintes diretrizes que permitam corrigir os problemas identificados na revisão bibliográfica e nos estudos de caso e desenvolver o processo de inovação da CPIC por meio da utilização de sistemas industrializados em obras públicas:

- Maior reflexão e aprofundamento na abordagem dos critérios

Conforme tratado anteriormente, identificou-se a necessidade de um maior aprofundamento na abordagem dos fatores determinantes para a escolha dos sistemas construtivos industrializados que supere os conceitos gerais apresentados pelo Manual de Obras Públicas da SEAP e que sejam adequados às necessidades do empreendimento.

Essa abordagem deve ser realizada com o estabelecimento dos objetivos estratégicos a serem alcançados com cada critério, a indicação dos requisitos de desempenho a serem atendidos e de indicadores que permitam avaliar o sucesso da aplicação desses critérios e pela consulta às referências normativas que determinam a utilização desses critérios - tais como leis, normas e manuais técnicos.

- Qualificação do Corpo técnico responsável pela tomada de decisões.

Decorrente da diretriz anterior, a qualificação técnica do quadro de agentes responsáveis pelo processo de planejamento, contratação e tomada de decisões se faz necessária tanto para corrigir os problemas identificados pela pesquisa, quanto para permitir o desenvolvimento da qualidade dos processos de contratação dos serviços técnicos e do planejamento dos empreendimentos públicos.

A qualificação proposta deve ser consolidada com a valorização das profissões com formação técnica nos campos de atuação na construção civil, a exemplo da arquitetura e das engenharias, e com o fortalecimento dessas carreiras nos quadros técnicos das diversas entidades da administração pública.

- Estabelecimento de Programas de qualidade das edificações públicas, alinhados à Construção Industrializada.

A revisão bibliográfica realizada pela presente pesquisa identificou que a atuação do Estado como agente catalisador do processo de inovação obtém maior sucesso quando realizada a partir do estabelecimento de demandas específicas com objetivos determinados (MAZZUCATO, 2014). 
Sendo assim, o estabelecimento de programas de qualidade das edificações públicas a partir da utilização de sistemas construtivos industrializados e demais áreas que compõem o modelo de construção industrializada nos processos licitatórios para contratação de serviços de projeto e planejamento e para a execução das obras pode funcionar como uma importante diretriz com objetivo de viabilizar a inovação da IC.

- Simplificação tributária e incentivos para o modo de produção

Conforme apresentado por ABDI (2015), o processo de construção industrializada apresenta quatro aspectos inerentes: Produção em fábrica, Contratação integrada dos projetos de produção e da execução dos sistemas; a forma de tributação e os arranjos de processos produtivos diferenciados.

Quanto a tributação, o fato de os sistemas construtivos industrializados serem tributados como produtos implicam em uma maior complexidade na incidência dos tributos, impactando no custo e dificultando a adoção desses sistemas como soluções técnicas. Dessa forma, a simplificação dos arranjos tributários incidentes nos sistemas construtivos industrializados podem favorece a intensificação do uso desses sistemas.

- Melhoria dos Aspectos Normativos

A análise da legislação referente ao processo de licitação das obras públicas revelou uma lacuna quanto à fase preliminar, carecendo de maior detalhamento dos aspectos técnicos, ambientais e socioeconômicos para o desenvolvimento do planejamento e dos projetos da obra pública, além de uma maior precisão na definição das competências e atividades necessárias para o desenvolvimento dessa fase.

No momento em que é discutida uma nova legislação no tocante à licitação dos serviços e aquisições voltados para as obras públicas, se faz necessária a inclusão de informações que permitam o maior detalhamento da fase preliminar, atribuindo maior importância à fase de planejamento e projeto - principalmente quando esses serviços forem realizados de modo terceirizado.

- Melhoria das Publicações técnicas

De forma complementar às determinações da diretriz anterior, se faz necessária a melhoria das publicações técnicas quanto ao detalhamento dos fatores associados à utilização de Sistemas construtivos industrializados, tais como o Manual de Obras Públicas do TCU, o Manual de Obras Públicas da SEAP e as Instruções Normativas do Ministério do Orçamento, Planejamento e Gestão (MPOG), já que essas publicações influenciam a formulação dos instrumentos licitatórios de maneira direta. 
- Qualificação técnica dos prestadores de serviço.

Embora não seja o objetivo da pesquisa, a análise das licitações permitiu observar que os critérios de avaliação nas modalidades Concorrência, Tomada de Preços e Convite não exploram devidamente os aspectos qualitativos dos concorrentes. Mesmo nas licitações do tipo Técnica e Preço a avaliação dos concorrentes é feita utilizando aspectos quantitativos relacionados à experiência deles, tais como a quantidade de área projetada.

Dessa forma, assim como é necessário um investimento no quadro técnico das entidades públicas, também o é a qualificação técnica dos prestadores de serviço. A melhoria da qualificação técnica pode ser induzida pela administração pública através da exigência de requisitos e conhecimentos específicos quanto à utilização de sistemas construtivos industrializados e demais áreas do modelo de construção industrializada.

Essa diretriz evidencia a inadequação da utilização do tipo Menor Preço como único critério de avaliação para a contratação de serviços técnicos, tais como o planejamento de obras públicas e a elaboração de projetos técnicos necessários à materialização dessas obras, uma vez que desconsidera a necessidade de conhecimentos e expertises específicas adequadas às especificidades dos empreendimentos em questão. 


\section{CONSIDERAÇÕES FINAIS}

Os conceitos e informações apresentados ao longo da pesquisa demonstram a importância da inovação no desenvolvimento de um sistema de produção e a necessidade de investimento em novas soluções de processos e produtos a fim de garantir a sobrevivência em um ambiente competitivo, não sendo diferente para a Indústria da Construção.

O sucesso desse processo depende da identificação de agentes capazes de conduzir o processo de transformação devido à sua capacidade de demanda e de suportar os riscos inerentes ao processo de inovação. A pesquisa identificou que o Estado tem a capacidade de atuar como agente catalizador, uma vez que ele possui, além dos atributos anteriores, o poder normativo e fiscalizador capaz de interferir e direcionar o comportamento de indivíduos e empresas sob sua influência e jurisdição.

No contexto nacional, o Estado brasileiro já possui, de forma clara, o papel de importante agente econômico da Indústria da Construção, uma vez que suas demandas correspondem a aproximadamente $1 / 3$ do PIB dessa indústria, além da participação por de programas e demandas específicas, como os programas habitacionais e de desenvolvimento de instituições (a exemplo do programa de Reestruturação e Expansão das Universidades Federais - REUNI) e dos grandes eventos esportivos realizados no país na presente década.

Dentre as formas de inovação passíveis de serem aplicadas no contexto da IC, a utilização de sistemas construtivos industrializados é capaz de solucionar problemas característicos dessa indústria, tais como a deficiência em produtividade e em qualidade e a melhor aplicação dos recursos naturais e econômicos, devido aos seus atributos e requisitos de projeto e execução e dos aspectos característicos desse processo construtivo.

O modelo de construção industrializada adotado pela pesquisa indica que o processo de industrialização da IC está associado à utilização de sistemas construtivos industrializados, embora não esteja restrito a ela, uma vez que o processo de gestão e a utilização de ferramentas tecnológicas no projeto e planejamento e na produção cumprem papel fundamental nesse modelo; sendo esse processo é caracterizado pela integração de diversas áreas de atuação, consistindo em um processo cíclico. 
Porém, há uma incompatibilidade natural entre esse modelo de construção industrializada e o processo que materializa as obras públicas, determinado pela legislação federal pertinente, que se caracteriza pelo aspecto linear das fases que o compõe e suas respectivas atividades e pela fragmentação entre essas fases e atividades, devido às determinações legais.

Entre as determinações que implicam na fragmentação colocada acima estão a necessidade da conclusão das etapas de projeto como condição para a contratação da obra, o que implica na falta de comunicação entre projetistas e executores, e a vedação da participação dos responsáveis pelos projetos básicos nos processos de contratação da obra, que também dificulta na integração que é própria da construção industrializada.

Como proposta de integração entre o modelo de construção industrializada e de obra pública, deve ser realizada a associação entre as fases da obra pública com as áreas que compõem o modelo de obra pública, de forma que a fase preliminar esteja relacionada com as áreas referentes ao planejamento e controle dos processos, ao desenvolvimento dos sistemas tecnicamente desenvolvidos, entre outras.

A partir da associação entre o modelo de Construção industrializada e o modelo de obra pública determinado pela legislação, constata-se que a utilização de sistemas industrializados está relacionada com a determinação dos requisitos e atributos desses sistemas como fatores determinantes no processo de tomada de decisão das soluções de projeto através de diretrizes que devem ser contempladas nos processos de contratação.

No entanto, a análise dos resultados obtidos pelo estudo de caso da pesquisa revela que a condição descrita acima não ocorre no contexto atual das contratações públicas, uma vez que os fatores relacionados à viabilidade técnica, ambiental e socioeconômica que estão associados a atributos e requisitos de projeto dos sistemas construtivos industrializados não são abordados de maneira consistente nos instrumentos das diferentes modalidades de licitação, tanto aspecto quantitativo quanto no qualitativo.

A inconsistência quantitativa da abordagem dos fatores citados é demonstrada pelas médias dos resultados das diferentes modalidades, que obtiveram como classificação máxima resultados regulares em poucos critérios da ferramenta, sendo predominante a classificação de resultados insatisfatórios ou ruins, com presença inferior a quatro processos licitatórios.

Já os aspectos qualitativos são ilustrados pela superficialidade das abordagens, que tratam esses fatores de forma pouco aprofundada, e pela repetição do texto referente aos 
critérios, o que denota a falta de reflexão sobre as necessidades da entidade e dos usuários da edificação objeto do contrato.

Mesmo os critérios que obtiveram bons resultados em termos quantitativos foram abordados sem a profundidade necessária; a exemplo do critério que trata do custo de execução, que na maioria das vezes foi tratado de maneira abstrata, sem determinação dos custos e sem a devida reflexão sobre os impactos dos custos indiretos no valor da obra e sobre as implicações do custo em termos de gestão pública, tais como a fonte de financiamento do empreendimento e o retorno social do mesmo.

Outro exemplo da deficiência exposta acima é a abordagem do critério referente à produtividade, que também obteve média intermediária, com um bom resultado na modalidade Técnica e Preço, sem, no entanto, expor maiores justificativas e implicações dos ganhos de produtividade, sendo abordada indiretamente em muitos casos.

Por fim, a carência de um maior aprofundamento nas reflexões e na abordagem dos critérios analisados é também demonstrada pela falta de integração ou associação entre fatores que estão naturalmente associados - tais como produtividade, prazo, interface entre os sistemas e mão de obra especializada; interface, flexibilidade e expansibilidade e operação, manutenção e custo de ciclo de vida.

Essas associações auxiliam no fortalecimento da importância de cada critério associado no processo de industrialização da construção e na compreensão da necessidade de uma visão holística de planejamento a fim de garantir o sucesso da implementação desse processo produtivo no empreendimento objeto da contratação.

Diante do exposto, os resultados acabam por revelar que, embora o estado brasileiro relevância no papel de agente econômico da CPIC, ele não tem atuado como agente catalisador do processo de inovação e que não há uma compreensão da Administração pública desse papel, uma vez que as entidades contratantes, por regra, não abordam os fatores capazes de induzir soluções inovadoras, ou os fazem de maneira insuficiente.

Ao considerar a determinação de demandas específicas como forma mais adequada de atuação do Estado no processo inovação, fica ainda mais evidente a abstenção da Administração Pública do papel que lhe cabe nesse processo, uma vez que os resultados e os achados de pesquisa indicam a ausência de políticas públicas quanto à utilização de sistemas industrializados em empreendimentos públicos devidamente formatadas e com objetivos precisos.

Essa abstenção se dá tanto pela falta de projetos e programas específicos para adoção de sistemas construtivos industrializados quanto na abordagem do tema da 
industrialização nos processos de licitação dos serviços técnicos para empreendimentos públicos, tal como mostrado pelos resultados da pesquisa.

Um critério que chama atenção ao evidenciar essa abstenção é o que trata da certificação de origem dos materiais e componentes, que apresentou média considerada insatisfatória e esteve ausente nos processos da modalidade convite, uma vez que, dada a capacidade de demanda da administração pública, esse critério ao ser exigido com frequência nas contratações públicas gera uma mudança no mercado fornecedor.

O baixo desempenho da exigência expressa da utilização de sistemas construtivos industrializados e racionalizados como soluções de projeto também exemplifica a falta de demandas específicas para a utilização desses sistemas por parte da administração pública e da sua abstenção do papel de indutora de mudanças no modo de produção da CPIC.

Os critérios avaliados pela pesquisa influenciam diretamente as cadeias de suprimento, principal e auxiliar, induzindo uma adequação na oferta de produtos e no modo de produção da cadeia de suprimentos, maior grau de especialização da cadeia principal quanto à execução e montagem dos sistemas in loco e maiores conhecimentos técnicos e qualidade das soluções de projetos fornecidas pela cadeia de suprimentos.

Quanto a esta última, a pesquisa ainda revelou a deficiência na abordagem dos aspectos qualitativos dos prestadores de serviço nas modalidades que avaliam o contratante em vez da proposta de projeto - concorrência, tomada de preços e convite uma vez que seus processos licitatórios não consideraram devidamente a expertise dos postulantes à contratação pública, considerando as experiências pregressas apenas por meio de aspectos quantitativos.

Outro ponto a ser considerado é a baixa requisição da utilização da plataforma BIM ou de estratégias voltadas para o gerenciamento dos projetos e das informações produzidas pelas diversas especialidades envolvidas no desenvolvimento dos projetos técnicos, estando esse ponto relacionado à área correspondente ao uso da Tecnologia da Informação do modelo de construção industrializada adotado pela pesquisa. Destaca-se ainda que essa área tem influência nas cadeias auxiliar e de suprimentos, auxiliando o projeto de produção.

O panorama apresentado demonstra a necessidade de mudança da forma de atuação do Estado quanto à industrialização da indústria da construção, devendo ele agir em três frentes básicas a fim de facilitar a utilização de sistemas industrializados nos empreendimentos públicos e na disseminação desses sistemas em outros setores: a questão normativa, as políticas públicas e os incentivos indiretos. 
O aspecto normativo se refere ao aprofundamento da legislação referente à licitação quanto à fase preliminar e quanto aos aspectos técnicos, ambientais e socioeconômicos; as políticas públicas buscam a promover a industrialização por meio de demandas específicas e de uma abordagem mais adequada dos critérios analisados pela pesquisa nas contratações públicas que fomentem a utilização dos SCI; já os incentivos indiretos tratam das barreiras tributárias e na facilitação do transporte dos produtos industrializados.

\subsection{Observações sobre a execução da pesquisa}

Para a execução da pesquisa, foi necessária a consulta dos instrumentos de licitação, o que fez com ela estivesse diretamente associada à disponibilidade de informações públicas, que por sua vez está vinculado ao princípio administrativo da publicidade ou transparência.

No entanto, a busca desses documentos no ambiente da internet se deu com certa dificuldade para acessar processos licitatórios que se adequassem aos condicionantes da pesquisa, o que demonstrou uma persistência dos problemas de transparência na administração pública. Por outro a pesquisa reconhece o pronto atendimento das diversas entidades públicas que disponibilizaram as informações e documentos públicos com pronto atendimento das demandas solicitadas.

Outro ponto a ser destacado foi a dificuldade de obter bibliografia referente à fase de planejamento preliminar, seja no âmbito acadêmico seja nas publicações técnicas do mercado ou da administração pública, tais como manuais técnicos. Essa ausência pode ser relacionada com o fato de a própria legislação pertinente não abordar a fase preliminar com grande profundidade, sendo que essas publicações tendem a acompanhar as determinações legais, o que evidencia a necessidade de revisão desse ponto na legislação em discussão.

\subsection{Sugestões para pesquisas futuras}

A presente pesquisa buscou identificar possíveis entraves para a utilização de sistemas construtivos industrializados nas obras públicas através da investigação da presença de fatores determinantes para o processo de industrialização nos instrumentos dos processos de licitação, se restringindo em aferir a intensidade dessa presença e em observar aspectos capazes de determinar um diagnóstico.

Dessa forma se faz necessário o desenvolvimento de um estudo que desenvolva a forma como cada um dos critérios pesquisados pela presente pesquisa deva ser trabalhado 
pelos processos licitatórios como diretrizes e premissas de projeto e pelas publicações técnicas e normativas, tais como manuais públicos e a legislação pertinente.

Outra diretriz proposta por esse trabalho que carece do desenvolvimento de uma pesquisa com maior detalhamento trata da importância da regulamentação das profissões técnicas da indústria da construção como carreiras de estado, a fim de fortalecer o quadro técnico das entidades públicas e evidenciar a necessidade dessa providência.

Por fim, sugere-se um aprofundamento quanto a questão da sustentabilidade nos processos de contratação pública através do desenvolvimento de diretrizes sustentáveis aplicáveis à legislação referente à licitação. 


\section{REFERÊNCIAS BIBLIOGRÁFICAS}

ACKER, Arnold Van. Manual de sistemas pré-fabricados de concreto. FIP-2002Tradução: Marcelo Ferreira (ABCIC-2003). ABCIC, 2013. 129p

ADDIS, W., SCHOUTEN, J. Principles of Design for Deconstruction to Facilitate Reuse and Recycling, London: Construction Industry Research and Information Association. 2004

AGÊNCIA BRASILEIRA DE DESENVOLVIMENTO INDUSTRIAL (ABDI) (Brasil). Manual da Construção Industrializada - Conceitos e Etapas, Volume 1: Estrutura e Vedação. 2016.

Agência Brasileira de Desenvolvimento Industrial (ABDI) (Brasil). Relatório Prospectivo Setorial: 2009. Brasília: Centro de Gestão e Estudos Estratégicos, 2009. P 104: $21 \mathrm{~cm}$.

ALEXANDRINO, Marcelo. Direito administrativo descomplicado / Marcelo Alexandrino, Vicente Paulo. - 20. Ed. Revle atual. - Rio de Janeiro: Forense; São Paulo: MÉTODO, 2012

ANDRADE, Nilton de Aquino. Contabilidade Pública na Gestão Municipal: Novos Métodos após a LC 101/00 e as Classificações Contábeis Advindas da SOF e STN. São Paulo: Atlas, 2002.

ANDRADE, Ricardo Barretto de; VELOSO, Vitor Lanza. Uma visão Geral solbre o regime diferenciado de contratações públicas: Objeto, objetivos, definições, princípios e diretrizes. 2012. Disponível em: http://www.justen.com.br/pdfs/IE60/IE60_Ricardo_e_ Vitor_RDC.pdf

ASSOCIAÇÃO BRASILEIRA DE NORMAS TÉCNICAS (ABNT). NBR 15.5751: Desempenho de edifícios habitacionais de até cinco pavimentos - parte 1: geral. São Paulo, 2013.

ASSOCIAÇÃO BRASILEIRA DE NORMAS TÉCNICAS (ABNT). NBR 13.531: Elaboração de projetos de edificações - Atividades Técnicas. 1994.

BEREZOWSKI, André Mainardes. Análise dos Custos de Obras Públicas. XIV Simpósio Nacional de Auditoria de Obras Públicas. Cuiabá. 2011. Disponível em: http://www.ibraop.org.br/acervo/XIV_sinaop/docs/AndreMainardes.pdf. Acessado em: 02 de janeiro de 2017.

BLACHÈRE, Gérard. Tecnologías de la construcción industrializada. Barcelona: Editorial Gustavo Gili, S. A., 1977. 168p. 
BLUMENSCHEIN, RAQUEL NAVES. A Sustentabilidade na Cadeia Produtiva da Indústria da Construção, 263 p., 24 mm, (UnB-CDS, Doutor, Política e Gestão Ambiental, 2004).

BRASIL, Ministério Das Cidades (MC). PBQP-H - Programa Brasileiro da Qualidade e Produtividade do Habitat. SINAT - http://pbqp-h.cidades.gov.br/download. php?doc $=$ e4d0ffb0-df04-46c0-9b03-170fd4819db9\&ext=.pdf\&cd $=. \quad$ Acessado em novembro de 2017.

BRASIL, Instituto Aço. Relatório de Sustentabilidade 2014. Rio de Janeiro: 2014, 93f.

BRASIL. Instituto Brasileiro de Geografia e Estatística. PAIC 2014

BRASIL. Instituto Brasileiro de Geografia e Estatística. Incorporações, obras e/ou serviços da construção registraram $-16,5 \%$ de 2014 para 2015. Disponível em: http://agenciadenoticias.ibge.gov.br/agenciasaladeimprensa/2013agenciadenoticias/reles es/10334releasepaic.html. Acessado em: 21 de junho de 2017.

BRASIL. Lei 8.666/93. Regulamenta o art. 37, inciso XXI, da Constituição Federal, institui normas para licitações e contratos da Administração Pública e dá outras providências. 1993.

BRASIL. Lei de $\mathrm{n}^{\circ}$. 10.520, de 17 de julho de 2002. Institui, no âmbito da União, Estados, Distrito Federal e Municípios, nos termos do art. 37, inciso XXI, da Constituição Federal, modalidade de licitação denominada pregão, para aquisição de bens e serviços comuns, e dá outras providências.

BRASIL. Lei 12.462/2011. Institui o Regime Diferenciado de Contratações Públicas (RDC). 2011.

BRASIL. Lei 13.303/2016. Dispõe sobre o estatuto jurídico da empresa pública, da sociedade de economia mista e de suas subsidiárias, no âmbito da União, dos Estados, do Distrito Federal e dos Municípios. 2016

BRASIL. Secretaria de Estado da Administração e Patrimônio - SEAP. Manual de Obras Públicas - Edificações. 1997.

BRASIL. Ministério Do Desenvolvimento, Indústria E Comércio Exterior. Fórum de competitividade: diálogo para o desenvolvimento. 2002. 17p. Documento Básico. Brasília.

BRASIL. MINISTÉRIO DO PLANEJAMENTO, ORÇAMENTO E GESTÃO MPOG. Instrução Normativa $n^{\circ} 05$ Dispõe sobre as regras e diretrizes do procedimento de 
contratação de serviços sob o regime de execução indireta no âmbito da Administração Pública federal direta, autárquica e fundacional. 2017

BRASIL. MINISTÉRIO DO PLANEJAMENTO, ORÇAMENTO E GESTÃO MPOG. Instrução Normativa $\mathrm{n}^{\circ} 01$. Dispõe sobre os critérios de sustentabilidade ambiental na aquisição de bens, contratação de serviços ou obras pela Administração Pública Federal direta, autárquica e fundacional e dá outras providências. 2010

BRASIL. Ministério da Saúde. Secretaria de Assistência à Saúde Série Saúde \& Tecnologia - Textos de Apoio à Programação Física dos Estabelecimentos Assistenciais de Saúde - Sistemas Construtivos na Programação Arquitetônica de Edifícios de Saúde Brasília - 1995. 53 p.

BRASIL. Tribunal de Contas da União - TCU. Processo 033.958/2010-6. 2010

BRASIL. Tribunal de Contas da União - TCU. Súmula 257. O uso do pregão nas contratações de serviços comuns de engenharia encontra amparo na Lei $n^{\circ}$ 10.520/2002. 2010 .

BRASIL. Tribunal de Contas da União. Obras públicas: recomendações básicas para a contratação e físcalização de obras públicas / Tribunal de Contas da União. 3. ed. Brasília : TCU, SecobEdif, 2013.

BRASIL. Tribunal de Contas da União. Obras públicas: recomendações básicas para a contratação e fiscalização de obras públicas / Tribunal de Contas da União. 4. ed. Brasília : TCU, 2014.

BRUNA, P. J. V. Arquitetura, Industrialização e Desenvolvimento. Editora Perspectiva, São Paulo, Brasil, 1976. CBCA; Manual da Construção Metálica - Steel Framing Arquitetura; Rio de Janeiro; 2006.

CAIXA. Selo Casa azul: O que é: Online. Disponível em: http:/www.caixa.gov.br/ sustentabilidade/produtos-servicos/selo-casa-azul/Paginas/default.aspx. Acesso em $30 \mathrm{de}$ outubro de 2017.

CAMARÃO, Tatiana; DANIEL, Felipe Alexandre Santa Anna. A fase interna de licitação - Distinções entre Projeto Básico e Termo de Referência. 2016. Disponível em: http://www.editoraforum.com.br/ef/index.php/noticias/afaseinternadalicitacaodistincoes entreprojetobasicoetermodereferencia/. Acessado em 23/03/2017

CARDOSO, Luiz Reynaldo de Azevedo. Metodologia de avaliação de custos de inovações tecnológicas na produção de habitações de interesse social. Boletim Técnico da Escola Politécnica da USP, Departamento de Engenharia de Construção, BT/PCC/249. 
22p. São Paulo: EPUS, 2000. Disponível em: http://durar.pcc.usp.br/files/text/ publications/BT_00249.pdf. Acesso em 23 de outubro de 2017.

CASTRO, Larissa Crivellari de. A gestão de projetos em órgãos públicos - um estudo de caso em unidades de saúde na Prefeitura de Juiz de Fora. 2013. 119p. Universidade Federal de Juiz de Fora. Faculdade de Engenharia. Dissertação (Mestrado em Ambiente Construído). 2013.

CENTRO BRASILEIRO DE CONSTRUÇÃO EM AÇO - CBCA. Light Steel Framing em empreendimentos de diferentes portes. Disponível em: http:/www.cbcaacobrasil.org.br/site/biblioteca-detalhes.php?cod=10105. Acesso em 07 de setembro de 2017.

CHANG, Ha-Joon. Chutando a escada: a estratégia do desenvolvimento em perspectiva histórica / Há-Joon Chang; tradução Luiz Antônio Oliveira de Araújo - São Paulo: Editora UNESP, 2004.

CONSELHO BRASILEIRO DA INDÚSTRIA DA CONSTRUÇÃO CIVIL CBIC. Boletim estatístico, ed.05, 2015

CRISTÓVAM, José Sérgio da Silva ; PIOVESAN, Filipe da Silva . A Nova Lei das Estatais e a aplicação de sanções nos contratos administrativos: uma análise comparativa com a Lei Geral de Licitações. REVISTA DE DIREITO ADMINISTRATIVO, v. 275, p. 223, 2017.

DURANTE, F. K. O uso da metodologia BIM (Building Information Modeling) para gerenciamento de projetos: Gerente BIM. 2013. 118p. Trabalho de Conclusão de Curso - Universidade Estadual de Londrina. Londrina, 2013

ELY, Daniela Matschulat. Proposta de um modelo para avaliação do processo de concorrência pública de obras ou serviços de engenharia / Daniela Matschulat Ely.. Florianópolis, SC, 2016.

ETZKOWITZ, Henry. The triple helix: university - industry - government innovation in action. Routledge, London. 2008.

FABRICIO, Marcio Minto. Projeto Simultâneo na construção de edifícios. São Paulo: POLI-USP, 2002, 329p.

FABRICIO, M. M. Industrialização das construções: revisão e atualização de conceitos. Pós. Revista do Programa de Pós-Graduação em Arquitetura e Urbanismo da FAUUSP, [S.1.], v. 20, n. 33, p. 228-248, jun. 2013. 
FERRARI, Maria Vitória Duarte; BLUMENSCHEIN, Raquel Naves; ZANONI, Vanda; SPOSTO, Rosa Maria. Guia de Compra Responsável: Gestão Estratégica e Mecanismos operacionais. - Brasília, 2015 - $1^{\text {a }}$ Edição.

FORMOSO, Carlos T.; CESARE, Cláudia M. de; LANTELME, Elvira M. V. e SOIBELMAN, Lúcio. As perdas na construção civil: conceitos, classificações e seu papel na melhoria do setor. 1996. Disponível em: 〈http://www.abepro.org.br/biblioteca/ ENEGEP1997_T3115.pdf〉. Acessado em 23 de setembro de 2016.

FILHA, C. M. et al. PERSPECTIVAS DO INVESTIMENTO 2010-2013: Construção Civil; BNDES, Rio de Janeiro, 2009.

FREEMAN, C. \& LUNDVALL, B.A. Small countries facing the technological revolution. London. Great Britain: Pinter Publishers Limited, 1988.

FULLER, Sieglinde. Life-Cycle Analaysis (LCCA). Whole Building Design Guide. 2010. Disponível em: https://archexamacademy.com/download/Building\%20 Design\%20Construction\%20Systems/Life-Cycle\%20Cost\%20Analysis.pdf. Acesso em: 31 de outubro de 2017.

GADELHA C.A.G. Estado e inovação: uma perspectiva evolucionista. Revista de Economia Contemporânea 2002; 6:85-117. Disponível em: https://www.arca.fiocruz.br/ handle/icict/18121. Acessado em: 21 de setembro de 2017.

GUITOUNI, Adel e MARTEL, Jean-Marc. Tentative guidelines to help choosing na appropriate MCDA method. European Journal of Operational Research. 1998

HAW, Kong Xi. Barriers in the implementation of industrialised building system in Malaysian Construction Industry. Faculty of Civil Engineering Universiti Teknologi Malaysia. 2009

HEINTZ, John L.; WAMELINK, J. W. F. Hans. Obercoming Barries to Innovation in the Building Industry. ResearchGate. 2015. Disponível em: https://www.researchgate.net/publication/281578911_Overcoming_Barriers_to_Innovat ion_in_the_Building_Industry. Acessado em: 19 de setembro de 2017.

HODGE, David R.; GILLESPIE, David. Phrase Completions: Na alternative to Likert Scales. Research Gate. 2003. Disponível em: https://www.researchgate.net /publication/234692602_Phrase_Completions_An_Alternative_to_Likert_Scales. Accessado em: 25 de outubro de 2017.

HOUSING CORPORATION (UK). A Guide to Modern Methods of Construction. Published by IHS BRE Press on behalf of NHBC Foundation, 2006. 
KAMAR, Kamarul Anual Mohd; HAMID, Zuhairi Abd; AZMAN, Mohamed Nor Azhari; AHAMAD, Mohd Sanusi S.. Industrialized Building System (IBS): Revisiting Issues of Denifition and Classification. ReserachGate. 2011.

KAMAR, K. A. M.; ALSHAWI, M.; HAMID, Z.. Barriers To industrialized Building System (IBS): The case of Malaysia. BuHu. The University of Salford. 2009. KAPLAN, Robert S. e NORTON, David P.; A Estratégia em Ação: balanced scorecard. Tradução Luiz Euclydes Trindade Frazão Filho - Rio de Janeiro: Campus, 1997.

KOSKELA, Lauri. Application of the New Production Philosophy to Construction. Finland, 1992.

\section{LABORATÓRIO DO AMBIENTE CONSTRUIIDO, INCLUSÃO E SUSTENTABILIDADE - LACIS; CONSELHO BRASILEIRO DA INDÚSTRIA DA CONSTRUÇÃO CIVIL - CBIC; BRITISH RESEARCH ESTABLISHMENT - BRE.} Parque de Inovação e Sustentabilidade do Ambiente Construído (PISAC) - Projeto Básico Versão 3.0. 2013.

LEMOINE, Bertrand. Aço, um material de construção ecológico para um desenvolvimento sustentável. [ca.2002]. Disponível em: http://www.cbcaiabr.org.br/ upfiles/downloads/Aco-um-material-de-construcao-ecologica-para-um-desenvolvimento -sustentavel.pdf > Acesso em: 28/04/20015

LESSING, Jerker. Industrialised House-Building, Concept and Processes.Department of Construction Sciences, Division of Design Methodology, Lund University, Lund. 2006.

LUNDVALL, Bengt-Åke, ed. National systems of innovation: Toward a theory of innovation and interactive learning. Pinter Publishers, London, 1992

DONNELL, Horacio Mac; DONNELL, Horacio Patricio Mac. Manual de Construcción Industrializada. Revista Vivienda. Buenos Aires. 1999.

MATTOS, Aldo Dórea. Como preparar orçamentos de obras: dicas para orçamentistas, estudos de caso, exemplos / Aldo Dórea Mattos. -- São Paulo: Editora Pini, 2006

MALMGREN, L. Industrialized construction - explorations of current practice and opportunities Faculty of Engineering and Division of Structural Engineering. Lund University. 2014

MAZZUCATO, Mariana. O estado empreendedor: Desmascarando o mito do setor público vs. Setor privado/ Mariana Mazzucato; tradução Elvira Srapico. - 1ªed. - São Paulo: Portfolio - Penguin, 2014. 
MONTEIRO FILHA, Dulce Correa et al. Perspectivas e entraves para inovações na construção civil. BNDES Setorial, n. 31, mar. 2010.

NAHMIAS, Pablo da Silva; FERREIRA, E. D. C.; KATO, R.B. A importância do projeto básico e do termo de referência para o processo licitatório da administração pública. 2013.

NISHIYAMA, Mario Augusto. Gestão de compras no setor público: Uma proposta multicritério para avaliação de desempenho / Mario Augosto Nishiyama. Florianópolis, SC, 2016.

OLIVEIRA, Ana Beatriz de Figueiredo. Inserção de sistemas industrializados de ciclo aberto estruturados em aço no mercado da construção civil brasileira [manuscrito] / Ana Beatriz de Figueiredo Oliveira. Universidade Federal de Ouro Preto. 2013. 155f.: il. color.; graf.; tab.

OLIVEIRA, O. J. ; MELHADO, S.B. . O papel do projeto em empreendimentos públicos: dificuldades em relação à qualidade. In: II WORKSHOP NACIONAL: gestão do processo de projeto na construção de edifícios, 2002, Porto Alegre. Anais do II WORKSHOP NACIONAL: gestão do processo de projeto na construção de edifícios, 2002. Disponível em: https://www.researchgate.net/publication/267202424_O_PAPEL_ DO_PROJETO_EM_EMPREENDIMENTOS_PUBLICOS_DIFICULDADES_E_POS SIBILIDADES_EM_RELACAO_A_QUALIDADE. Acessado em: outubro de 2017

PALUDO, Augustinho Vicente. Orçamento público e administração financeira e orçamentária e LRF / Augustinho Vicente Paludo. - 4. ed. - Rio de Janeiro: Elsevier, 2013

PERALTA, Antonio Carlos. Um modelo do processo de projeto de edificações, baseado na Engenharia simultânea em empresas construtoras incorporadoras de pequeno porte. 2002. 139p. Dissertação (Mestrado em Engenharia de Produção) - Programa de Pós-graduação em Engenharia de Produção, UFSC, Florianópolis.

PINHO, Fernando Ottoboni. Viabilidade Econômica / Fernando Ottoboni Pinho, Fernando Penna. - Rio de Janeiro: IBS / CBCA, 2008. 84 p.; 29cm. - (Série Manual de Construção em Aço)

RIBEIRO, Marcellus Serejo. A Industrialização como Requisito para a Racionalização da Construção. Rio de Janeiro: UFRJ / PROARQ / FAU , 2002. iii, 93p. $29,7 \mathrm{~cm}$.

ROCHA LIMA JR. João da. Qualidade do Empreendimento na construção Civil: Inovação e Competitividade. São Paulo. EPUSP, 1995. Boletim Técnico da Escola 
Politécnica da USP. Departamento de Engenharia de Construção Civil, BT/PCC/144. 44p. Disponível em: http://www.pcc.usp.br/files/text/publications/BT_00144.pdf. Acessado em: 15 de setembro de 2017.

ROGERS, Everett M. Diffusion of innovations. Rev. ed. of: Communication of innovations. 2nd ed. 1971.

ROSSO, Teodoro. Racionalização da construção. São Paulo: Ed. FAU-USP, 1980. 300 p.

SANTIAGO, Alexandre Kokke Steel framing: arquitetura / Alexandre Kokke Santiago, Arlene Maria Sarmanho Freitas, Renata Cristina Moraes de Crasto. - Rio de Janeiro: Instituto Aço Brasil/ CBCA, 2012.

SCHUMPETER, Joseph Alois. A Teoria do Desenvolvimento Econômico: uma investigação sobre lucros, capital, credito, juro e o ciclo econômico. 3. ed. São Paulo: Nova Cultural, 1997.

SILVA, Wesley Pereira da Critérios de sustentabilidade para contratações de obras na administração pública - PR. / Wesley Pereira da Silva. -- Ponta Grossa, 2013.75 f.

SILVA, Wainer da Silveira e; RICO, Maria Alejandra; RIBEIRO, Thiago de Oliveira; PEREIRA, Victor Hugo de Oliveira. Balanced Scorecard aplicado a construção civil no setor Público. Congresso Nacional de Excelência em Gestão. 2015. Disponível em: http://www.inovarse.org/sites/default/files/T_15_262.pdf. Acesso em: maio de 2017.

SOARES, S. R., SOUZA, D. M. de, PEREIRA, S. W. A avaliação do Ciclo de Vida no Contexto da Construção Civil. In: SATTLER, M. A., PEREIRA, F. A. R. Construção e Meio Ambiente. v.7. Habitare. Porto Alegre, 2006.

SOBREIRA, F. J. A.; GOMES, E. ; GUERRA, J. ; VAZ, S.; MAIA, V.; OLIVEIRA, L.. Sustentabilidade em Edificações Públicas: Entraves e Perspectivas. Brasília: Ministério do Meio Ambiente, 2007 (Artigo Técnico).

VIOTTI, E.B. Passive and active national learning systems. 1997. 311f. Tese (Doutorado em Filosofia). The Graduate Faculty of Political and Social Science of the New School for Social Research, EUA.

VIVAN, André Luiz; PALIARI, José Carlos; NOVAES, Celso Carlos. Vantagem produtiva do sistema Light Steel Framing: Da construção enxuta à racionalização construtiva. XIII Econtro Nacional de Tecnologia do Ambiente Construído - ENTAC 2010. 2010. Disponível em: https://www.aea.com.br/blog/vantagem-produtiva-dosistema-light-steel-framing-da-construcao-enxuta-a-racionalizacao-construtiva/. Acessado em: setembro de 2017. 


\section{INSTRUMENTOS DE LICITAÇÃO}

ESTADO DO CEARÁ. Assembleia Legislativa do Estado do Ceará. Termo de Referência da Concorrência Pública $\mathrm{N}^{\mathrm{o}}$ 03/2016-CP. Disponível em: $<$ http://www.al.ce.gov.br/paineldecontrole/pdopdf.php?f_cod=12958441>. Acesso em: 12 jan.2017.

ESTADO DO CEARÁ. Assembleia Legislativa do Estado do Ceará. Edital da Concorrência Pública $\quad \mathrm{N}^{\mathrm{a}}$ 03/2016-CP. Disponível em: $<$ https://www.al.ce.gov.br/paineldecontrole/pdopdf.php?f_cod=12962263>. Acesso em: 12 jan.2017.

BRASIL. Escola Nacional de Administração Pública (ENAP). Edital da Concorrência Pública $\quad N^{o}$ 01/ENAP/2014. Disponível em: < http://www.enap.gov.br/documents/586044/592372/edital_de_concorrencia_n_01_2014 _projeto_executivo_de_arquitetur_e_engenharia_para_a_enap.doc/527f9e0e-2d9948bc-9da2-d4fa23ff51c6>. Acesso em: 13 jan.2017.

BRASIL. Instituto Federal de Educação, Ciência e Tecnologia do Maranhão. Edital Concorrência No 01/2015/IFMA. Disponível em: <http://www2.ifma.edu.br/gercon/ sistema/upload_arquivos/montecastelo/30062015-111241CP_TECNICA_E_PRECOS_ PRECO_GLOBAL_-_JUN_2015_-_RETIFICADO.pdf>. Acesso em: 13 jan.2017.

BRASIL. Instituto Federal de Educação Ciência e Tecnologia do Triângulo Mineiro. Edital de Concorrência N $N^{o}$ 02/2013. Disponível em: < http://ptdocz.com/doc/553988/edital-de-concorr\%C3\%AAncia-n\%C2\%BA-02-2013sistema-de-registro $>$. Acesso em: 05/01/2017.

MUNICÍPIO DE PORTO ALEGRE. Secretaria Municipal de Fazenda. Edital de Concorrência $\mathrm{N}^{0}$ 4/2016. Disponível em: <https://www.google.com.br/url?sa=t\&rct= $\mathrm{j} \& \mathrm{q}=\&$ esrc $=\mathrm{s} \&$ source $=$ web $\& \mathrm{~cd}=1 \& \mathrm{cad}=\mathrm{rja} \&$ uact $=8 \& \mathrm{ved}=0 \mathrm{ahUKEwjCyK} 6 Z 7 \mathrm{OHUAh}$ WHTZAKHfRuDx8QFggnMAA\&url=http\%3A\%2F\%2Flproweb.procempa.com.br\%2 Fpmpa\%2Fprefpoa\%2Fsmf\%2Fusu_doc\%2Fedital_concorrencia04_2016_com_anexos. pdf\&usg=AFQjCNEwnyOzfLJsQRIEs2gFMvtC-QDXYw>. Acesso em: 12 jan. 2017

BRASIL. Superior Tribunal Militar. Edital de Licitação da Concorrência No 001/2013 - DEC/DPE. Disponível em: <http://cpsustentaveis.planejamento.gov.br /assets/conteudo/uploads/concorrencia-12013sede-stm.pdf>. Acesso em: 12 jan. 2017 
ESTADO DO PIAUÍ. Universidade Estadual do Piauí. Edital de Licitação da Concorrência $\quad \mathrm{N}^{\mathrm{o}} \quad$ 002.2016. Disponível em: <http://www.uespi.br/site/wpcontent/uploads/edital-cl\%C3\%B3vis-moura.pdf>. Acesso em: 09 de março de 2017.

ESTADO DO PIAUÍ. Universidade Estadual do Piauí. Edital de Licitação da Concorrência $\quad \mathrm{N}^{\mathrm{o}} \quad$ 001.2016. Disponível em: <http://www.uespi.br/site/wpcontent/uploads/edital-torquato-neto.pdf>. Acesso em: 09 de março de 2017.

ESTADO DE RONDÔNIA. Tribunal de Justiça do Estado de Rondônia. Edital de Licitação Concorrência No 001/2015. Disponível em: https://www.tjro.jus.br/images/ Arquivos/Licita\%C3\%A7\%C3\%B5es/Editais_2015/EDITALCP001.2015.pdf. Acesso em: 07 de novembro 2017

BRASIL. Universidade Federal de Uberlândia. Edital de Licitação da Concorrência No 006/2014. Disponível em: http://www.sinduscontap.com.br/arquivos/Licitacoes/ EditalLicita309-00614\%20_1_.pdf. Acesso em: 02 de novembro de 2017.

BRASIL. Universidade Federal de Uberlândia. Projeto Básico da Concorrência $N^{o}$ 006/2014. Disponível em: lvieira@ufu.br. Acesso em 08 de novembro de 2017.

BRASIL. Fundação de Empreendimento Científicos e Tecnológicos. Edital de Licitação da Tomada de Preço $\mathrm{N}^{\mathrm{o}}$ 002/2015. Disponível em: $<$ http://www.finatec.org.br/site08//files/licitacoes/2015/Edital_TM_002_2015_Projeto_ Conceitual_Basico_Executivo_RETIFICADO.pdf>. Acesso em: 26 jan. 2017

BRASIL. Justiça Federal de Primeiro Grau em Minas Gerais. Edital de Licitação da Tomada de Preços 1/2015. Disponível em: <http://www.jfmg.jus.br/Publicacao/Licitacao/TP0115.pdf>. Acesso em: 26 jan. 2017.

BRASIL. Tribunal Regional Eleitoral de Alagoas. Edital de Licitação da Tomada de Preços $\mathrm{n}^{\mathrm{o}}$ 01/2015. Disponível em: $<$ https://app.treal.jus.br/licitacao/index.jsp?ano=2015>. Acesso em: 20 dez. 2016.

BRASIL. Tribunal Regional Eleitoral da Paraíba. Edital de Licitação da Tomada de Preços $\quad n^{\circ}$ 05/2014-TER/PB. Disponível em: <http://www.trepb.jus.br/transparencia/licitacoes/tomada-de-precos>. Acesso em: 26 jan. 2017.

BRASIL. Tribunal Regional Eleitoral de São Paulo. Edital de Licitação da Tomada de Preços $\mathrm{n}^{\mathrm{o}}$ 02/2013. Disponível em: $<$ http://www.tresp.jus.br/transparencia/licitacoes/editais-1/copy_of_editais-2013>. Acesso em: 10 jan. 2017.

BRASIL. Justiça Federal de Primeiro Grau - Seção Judiciária do Estado de Goiás. Edital de Licitação da Tomada de Preço 01/2014-JFGO. Disponível em: < 
http://www.jfgo.jus.br/transparencia/licitacoes/recupera_anexo.php?id=3023>. Acesso em: 10 jan. 2017.

ESTADO DE SÃO PAULO. Edital de Licitação da Tomada de Preços No 36/2015. Disponível em: <http://www.sef.usp.br/wp-content/uploads/sites/52/2016/01/ TP-362015-Edital.pdf>. Acesso em 03 março 2017.

BRASIL. Universidade Tecnológica Federal do Paraná. Projeto Básico para Contratação de Empresa Especializada no Ramo de Projetos Arquitetônicos e de Engenharia da Tomada de Preços TP 002-2013. Disponível em: $<\mathrm{http}$ ://www.utfpr.edu.br/londrina/licitacoes/tomada-de-precos/2013/tomada-de-precos002-2013/tomada-de-precos-002-2013>. Acesso em: 10 jan. 2017.

CONSELHO REGIONAL DE ENGENHARIA E AGRONOMIA DO PARANÁ. Edital de Licitação da Tomada de Preços No 002/2017. Disponível em: <http://www.creapr.org.br/ws/wp-content/uploads/2011/09/2017_11230_No_015-17_T_002_-_Projeto _basico___Reforma_Cascavel.pdf>. Acesso em: Novem de 2017.

MUNICÍPIO DE COTIA. Câmara Municipal de Cotia - SP. Edital de Licitação da Tomada de Preços No 01/2016. Disponível em: <http://www.cotia.sp.leg.br/licitacoes1/tomada-de-precos-01-2016/Tomada\%20de\%20Precos\%2001-16.pdf/at_download/ file>. Acesso em: Novembro de 2017.

BRASIL. Banco Nacional de Desenvolvimento Econômico e Social. Edital do Concurso AA $\quad \mathrm{N}^{\mathrm{N}} \quad 01 / 2014 \quad-\quad$ BNDES. Disponível em: <www.bndes.gov.br/concursoanexobndes>. Acesso em: 09 jan. 2017

MUNICÍPIO DE PORTO ALEGRE. Câmara Municipal de Porto Alegre. Edital do Concurso Público Nacional de Arquitetura para a Sede Administrativa da Câmara Municipal de Porto Alegre, em Porto Alegre, RS. Disponível em: $<$ http://www.iabrs.org.br/concursocamarapoa/>. Acesso em: 09 jan. 2017.

MUNICÍPIO DE PORTO ALEGRE. Câmara Municipal de Porto Alegre. Termo de Referência do Concurso Público Nacional de Arquitetura para a Sede Administrativa da Câmara Municipal de Porto Alegre, em Porto Alegre, RS. Disponível em: $<$ http://www.iabrs.org.br/concursocamarapoa/>. Acesso em: 09 jan. 2017.

DISTRITO FEDERAL. Companhia de Desenvolvimento Habitacional do Distrito Federal. Edital de Concurso $\mathrm{N}^{\mathrm{o}}$ 01/2016. Disponível em; <www.codhab.df.gov.br/concursos/parquedoriacho-cei>. Acesso em: 09 jan. 2017. 
DISTRITO FEDERAL. Companhia de Desenvolvimento Habitacional do Distrito Federal. Termo de Referência de Concurso $N^{o}$ 01/2016. Disponível em; $<$ www.codhab.df.gov.br/concursos/parquedoriacho-cei>. Acesso em: 09 jan. 2017.

DISTRITO FEDERAL. Companhia de Desenvolvimento Habitacional do Distrito Federal. Edital de Concurso $\mathrm{N}^{\mathrm{o}}$ 02/2016. Disponível em; $<$ http://www.codhab.df.gov.br/concursos/parquedoriacho-cef $>$. Acesso em: 09 jan. 2017.

DISTRITO FEDERAL. Companhia de Desenvolvimento Habitacional do Distrito Federal. Termo de Referência de Concurso $\mathrm{N}^{\mathrm{o}}$ 02/2016. Disponível em; $<$ http://www.codhab.df.gov.br/concursos/parquedoriacho-cef $>$. Acesso em: 09 jan. 2017.

ESTADO DE SANTA CATARINA. Fundação do Meio Ambiente de Santa Catarina e Fundação de Amparo à Pesquisa e Inovação do Estado de Santa Catarina. Edital do Concurso Nacional de Arquitetura IAB/SC 001-2012. Disponível em: $<$ www.iab-sc.org.br/concursofatmafapesc >. Acesso em: 03 março 2017.

ESTADO DE SANTA CATARINA. Fundação do Meio Ambiente de Santa Catarina e Fundação de Amparo à Pesquisa e Inovação do Estado de Santa Catarina. Termo de Referência do Concurso Nacional de Arquitetura IAB/SC 001-2012. Disponível em: <www.iab-sc.org.br/concursofatmafapesc>. Acesso em: 03 março 2017.

BRASIL. Instituto de Arquitetos do Brasil - Departamento Tocantins. Edital de Concurso Nacional de Ideias para Elaboração de Projeto Arquitetônico para o Edifício Sede do Instituto de Arquitetos do Brasil, Departamento Tocantins em Palmas-TO. Disponível em: <http://iabto.blogspot.com>. Acesso em: 03 de março de 2017.

BRASIL. Conselho de Arquitetura e Urbanismo do Brasil e Instituto de Arquitetos do Brasil - Departamento Distrito Federal. Edital de Concurso. Disponível em: $<$ http://www.caubr.gov.br/novasede>. Acesso em: 09 jan. 2017.

BRASIL. Fundação Universidade Federal de Ciências da Saúde de Porto Alegre. Edital Concurso $\mathrm{N}^{\mathrm{o}}$ 001/UFCSPA/2014. Disponível em: <http://www.ufcspa.edu.br/ufcspa/ editaisconcelic/projetos/concurso-01-2014-campus-igara.pdf $>$. Acesso em: 09 jan. 2017.

ESTADO DO MARANHÃO. Governo do Estado do Maranhão. Edital de Concurso. Disponível em: iabdf@iabdf.org.br. Acesso em: 14 de março de 2017.

ESTADO DO MARANHÃO. Governo do Estado do Maranhão. Termo de Referência de Concurso. Disponível em:<iabdf@iabdf.org.br>. Acesso em: 14 de março de 2017. 
MUNICÍPIO DE BELO HORIZONTE. Prefeitura de Belo Horizonte. Edital de Concurso de Projeto. Disponível em: <http://portalpbh.pbh.gov.br/pbh/ecp/comunidade. do? app=concursocentroadministrativo $>$. Acesso em: março de 2017.

MUNICÍPIO DE BELO HORIZONTE. Prefeitura de Belo Horizonte. Termo de Referência de Concurso de Projeto. Disponível em: $<$ http://portalpbh.pbh.gov.br/pbh/ecp /comunidade.do?app=concursocentroadministrativo>. Acesso em: março de 2017.

CONSELHO FEDERAL DE FONOAUDIOLOGIA. Carta-Convite No 01/2015. Disponível em: <http://www.fonoaudiologia..br/cffa/wp-content/uploads/2013/07/ edital -e-anexos5.pdf> . Acesso em: 21 de novembro org de 2017.

MUNICÍPIO DE CANITAR. Câmara Municipal de Canitar. Edital do Convite $\mathrm{N}^{\mathrm{o}}$ 03/2015. Disponível em: <http://www.camaracanitar.com.br/Edital-Convite\%2003. 2015. pdf>. Acesso em: 21 de Novembro de 2017.

MUNICÍPIO DE VENDA NOVA DO IMIGRANTE. Câmara Municipal de Venda Nova do Imigrante. Convite 001/2012. Disponível em: < http://www.camaravni.es.gov.br /sno/licitacoes/CONVITE\%20N\%C2\%BA002-2012\%20Corrigido\%2026-102012.pdf>. Acesso em: 22 de novembro de 2017.

CONSELHO REGIONAL DE CORRETORES DE IMÓVEIS DE MINAS GERAIS - CRECI/4 REGIÃO. Edital de Licitação Convite No 001/2014. Disponível em: $<$ http://www.crecimg.gov.br/Paginas/id-89/Titulo-Editais/>. Acesso em: 21 de novembro de 2017.

CONSELHO REGIONAL DE CORRETORES DE IMÓVEIS DE MINAS GERAIS - CRECI/4 REGIÃO. Termo de Referência de Licitação Convite No 001/2014. $<$ Disponível em: http://www.crecimg.gov.br/Paginas/id-89/Titulo-Editais/>. Acesso em: 13 de novembro de 2017.

CONSELHO FEDERAL DE EDUCAÇÃO FÍSICA DA 9a REGIÃO ESTADO DO PARANÁ - CREF9/PR. Carata Convite No 009/2014. Disponível em: $<$ http://www.crefpr.org.br/wp-content/uploads/2014/09/Edital-ENGENHARIA.doc $>$. Acesso em: 01 de novembro de 2017.

CONSELHO FEDERAL DE FARMÁCIA. Edital do Convite de Preços $\mathrm{N}^{\circ}$ 002/2014. Disponível em: <http://www.crfgo.org.br/wp-content/uploads/2015/07/Edital CartaConvite022014ElaboracaoDeProjetos.pdf>. Acesso em: 21 de novembro de 2017.

CONSELHO FEDEREAL DE FARMÁCIA DO ESTADO DE PERNAMBUCO. Edital de Licitação Convite $N^{o}$ 001/2015. Disponível em: <http://www.crfpe.org.br/ transparencia/licitacao/editalconvite00120153conv.pdf>. Acesso em: novembro de 2017. 
CONSELHO REGIONAL DE PSICOLOGIA DA $17^{\mathrm{a}}$ REGIÃO. Carta Convite CRP/17 No 001/2015. Disponível em: <http://crprn.org.br/documentos/Licitacao-novasede-1-PARA-ENVIO.pdf $>$. Acesso em: 22 de novembro de 2017.

FUNDAÇÃO DE AMPARO À PESQUISA DO ESTADO DE SÃO PAULO FAPESP. Edital de Convite No 01/2017. Disponível em: <http://www.fapesp.br/licitacao/ convite_012017.pdf $>$. Acesso em: 22 de novembro de 2017.

FUNDAÇÃO DIAMANTINENSE DE APOIO AO ENSINO, PESQUISA E EXTENSÃO - FUNDAEPE. Edital de Licitação Convite No 01/2016. Disponível em: $<$ http://www.fundaepe.org.br/docs/EDITAL\%20_carta\%20_convite\%20_01_2016.pdf> . Acesso em: 22 de novembro de 2017. 
APÊNDICES 


\section{APÊNDICE A}

Quadro 01: Aspectos Técnicos - Prazo de Construção / Modalidade Concurso

\begin{tabular}{|c|c|c|c|c|c|}
\hline \multicolumn{6}{|c|}{ SÍNTESE ACHADOS DE PESQUISA } \\
\hline Modalidade & $\begin{array}{l}\text { Concurso de } \\
\text { Projeto }\end{array}$ & Categoria & $\begin{array}{l}\text { Aspectos } \\
\text { Técnicos }\end{array}$ & Critério & $\begin{array}{l}\text { Prazo de } \\
\text { Construção }\end{array}$ \\
\hline Entidade & $\begin{array}{c}\text { Localização } \\
\text { Instrumento } \\
\text { Licitatório }\end{array}$ & \multicolumn{4}{|c|}{ Conteúdo } \\
\hline $\begin{array}{l}\text { CAU-BR / } \\
\text { IAB-DF }\end{array}$ & TR item 2.5 & \multicolumn{4}{|c|}{$\begin{array}{l}\text {... os concorrentes deverão planejar a execução da obra em } \\
\text { prazo curto, de dez meses a um ano. }\end{array}$} \\
\hline $\begin{array}{l}\text { CODHAB- } \\
\text { CEB }\end{array}$ & TR item 6.§5응 & \multicolumn{4}{|c|}{$\begin{array}{l}\text {... Em razão das exigências de prazo para a finalização da obra, } \\
\text { tendo em vista a previsão de entrega do Empreendimento } \\
\text { Parque do Riacho para o final de 2015, a CODHAB/DF dará } \\
\text { prioridade a soluções projetuais que utilizem sistemas } \\
\text { construtivos que demandem menor tempo de execução... }\end{array}$} \\
\hline $\begin{array}{l}\text { CODHAB- } \\
\text { CEF }\end{array}$ & TR item 6.§5응 & \multicolumn{4}{|c|}{$\begin{array}{l}\text {... Em razão das exigências de prazo para a finalização da obra, } \\
\text { tendo em vista a previsão de entrega do Empreendimento } \\
\text { Parque do Riacho para o final de 2015, a CODHAB/DF dará } \\
\text { prioridade a soluções projetuais que utilizem sistemas } \\
\text { construtivos que demandem menor tempo de execução... }\end{array}$} \\
\hline
\end{tabular}

Quadro 02: Aspectos Técnicos - Produtividade / Modalidade Concurso.

\begin{tabular}{|c|c|c|c|c|c|}
\hline \multicolumn{6}{|c|}{ SÍNTESE ACHADOS DE PESQUISA } \\
\hline Modalidade & $\begin{array}{l}\text { Concurso de } \\
\text { Projeto }\end{array}$ & Categoria & $\begin{array}{l}\text { Aspectos } \\
\text { Técnicos }\end{array}$ & Critério & Produtividade \\
\hline Entidade & $\begin{array}{l}\text { Localização } \\
\text { Instrumento } \\
\text { Licitatório }\end{array}$ & \multicolumn{4}{|c|}{ Conteúdo } \\
\hline BNDES & $\begin{array}{l}\text { Edital item } \\
\text { 7.1.c }\end{array}$ & \multicolumn{4}{|c|}{$\begin{array}{l}\text { sistema construtivo - uso de técnica construtiva geral que vise } \\
\text { à economicidade e à exequibilidade... }\end{array}$} \\
\hline CM-POA & $\begin{array}{l}\text { TR item } \\
5.1 . \S 3 \text { 이 }\end{array}$ & \multicolumn{4}{|c|}{$\begin{array}{l}\text { um prédio inteligente, que seja composto por um conjunto de } \\
\text { sistemas e técnicas construtivas pensadas em conjunto e de } \\
\text { forma a permitir uma excelente construção }\end{array}$} \\
\hline & $\begin{array}{l}\text { TR item } \\
5.1 . \S 49\end{array}$ & \multicolumn{4}{|c|}{$\begin{array}{l}\text { sistema moderno e eficiente ... além de aumentar a velocidade } \\
\text { da construção }\end{array}$} \\
\hline $\begin{array}{l}\text { CAU-BR / } \\
\text { IAB-DF }\end{array}$ & TR item 8.3.VI & \multicolumn{4}{|c|}{$\begin{array}{l}\text { Privilegiar a agilidade construtiva, a economicidade e a } \\
\text { facilidade de manutenção. }\end{array}$} \\
\hline $\begin{array}{l}\text { CODHAB - } \\
\text { CEB }\end{array}$ & TR item $6 . \S 50$ & \multicolumn{4}{|c|}{$\begin{array}{l}\text {... serão analisadas: a adoção de soluções construtivas } \\
\text { racionais e eficientes, elegendo-se, sempre que possível, } \\
\text { sistemas de modulação e padronização... }\end{array}$} \\
\hline $\begin{array}{l}\text { CODHAB - } \\
\text { CEF }\end{array}$ & TR item $6 . \S 50$ & \multicolumn{4}{|c|}{$\begin{array}{l}\text {... serão analisadas: a adoção de soluções construtivas } \\
\text { racionais e eficientes, elegendo-se, sempre que possível, } \\
\text { sistemas de modulação e padronização... }\end{array}$} \\
\hline $\begin{array}{l}\text { FATMA / } \\
\text { FAPESC }\end{array}$ & $\begin{array}{l}\text { Regulamento } \\
\text { item } 10.13\end{array}$ & \multicolumn{4}{|c|}{$\begin{array}{l}\text { São critérios básicos de julgamento, a serem utilizados e } \\
\text { explicitados pelo Júri na Ata de seleção dos trabalhos: ... } \\
\text { exequibilidade ... }\end{array}$} \\
\hline
\end{tabular}


Quadro 03: Aspectos Técnicos - Qualidade / Modalidade Concurso.

\begin{tabular}{|c|c|c|c|c|c|}
\hline \multicolumn{6}{|c|}{ SÍNTESE ACHADOS DE PESQUISA } \\
\hline Modalidade & $\begin{array}{c}\text { Concurso de } \\
\text { Projeto }\end{array}$ & Categoria & $\begin{array}{l}\text { Aspectos } \\
\text { Técnicos }\end{array}$ & Critério & Qualidade \\
\hline Entidade & $\begin{array}{l}\text { Localização } \\
\text { Instrumento } \\
\text { Licitatório }\end{array}$ & \multicolumn{4}{|c|}{ Conteúdo } \\
\hline $\begin{array}{l}\text { CAU-BR / } \\
\text { IAB-DF }\end{array}$ & TR item 8.3 & \multicolumn{4}{|c|}{$\begin{array}{l}\text { A proposta deve levar em consideração questões relativas à } \\
\text { funcionalidade, qualidade e sustentabilidade (ambiental, } \\
\text { econômica, social e cultural), utilizando soluções que traduzam } \\
\text { esses quesitos com o menor impacto possível, incorporando, } \\
\text { sempre que conveniente, novas tecnologias que acarretem em } \\
\text { maior eficiência, em seus aspectos construtivo, funcional e } \\
\text { estético. }\end{array}$} \\
\hline $\begin{array}{l}\text { CODHAB - } \\
\text { CEB }\end{array}$ & $\begin{array}{l}\text { TR item } \\
6 . \S 50\end{array}$ & \multicolumn{4}{|c|}{$\begin{array}{l}\text { a CODHAB/DF dará prioridade a soluções projetuais que utilizem } \\
\text { sistemas construtivos que demandem menor tempo de } \\
\text { execução sem prejuízo à qualidade, à economicidade e à } \\
\text { sustentabilidade. Ou seja, serão analisadas: a adoção de } \\
\text { soluções construtivas racionais e eficientes, elegendo-se, } \\
\text { sempre que possível, sistemas de modulação e padronização; }\end{array}$} \\
\hline $\begin{array}{c}\text { CODHAB - } \\
\text { CEF }\end{array}$ & $\begin{array}{l}\text { TR item } \\
6 . \S 50\end{array}$ & \multicolumn{4}{|c|}{$\begin{array}{l}\text { a CODHAB/DF dará prioridade a soluções projetuais que utilizem } \\
\text { sistemas construtivos que demandem menor tempo de } \\
\text { execução sem prejuízo à qualidade, à economicidade e à } \\
\text { sustentabilidade. Ou seja, serão analisadas: a adoção de } \\
\text { soluções construtivas racionais e eficientes, elegendo-se, } \\
\text { sempre que possível, sistemas de modulação e padronização; }\end{array}$} \\
\hline $\begin{array}{l}\text { FATMA / } \\
\text { FAPESC }\end{array}$ & $\begin{array}{l}\text { TR item } \\
7 \S 70\end{array}$ & \multicolumn{4}{|c|}{$\begin{array}{l}\text { Não obstante, considera-se como premissa básica e essencial do } \\
\text { projeto uma alta qualidade arquitetônica e a agregação de } \\
\text { novas tecnologias em sintonia com as questões de } \\
\text { sustentabilidade levantadas. }\end{array}$} \\
\hline
\end{tabular}


Quadro 04: Aspectos Técnicos - Flexibilidade / Modalidade Concurso.

\begin{tabular}{|c|c|c|c|c|c|}
\hline \multicolumn{6}{|c|}{ SÍNTESE ACHADOS DE PESQUISA } \\
\hline Modalidade & $\begin{array}{l}\text { Concurso de } \\
\text { Projeto }\end{array}$ & Categoria & $\begin{array}{l}\text { Aspectos } \\
\text { Técnicos }\end{array}$ & Critério & Flexibilidade \\
\hline Entidade & $\begin{array}{l}\text { Localização } \\
\text { Instrumento } \\
\text { Licitatório } \\
\end{array}$ & \multicolumn{4}{|c|}{ Conteúdo } \\
\hline BNDES & $\begin{array}{l}\text { Edital item } \\
\text { 7.1.b }\end{array}$ & \multicolumn{4}{|c|}{$\begin{array}{l}\text { atendimento às condicionantes e funções previstas no Anexo I } \\
\text { deste Edital (Programa de Necessidades) ... flexibilidade e } \\
\text { reversibilidade... }\end{array}$} \\
\hline CA-BH & TR item 3.4 & \multicolumn{4}{|c|}{$\begin{array}{l}\text { As áreas de escritório deverão ser resolvidas em andares } \\
\text { corridos, com infraestrutura de shafts (verticais e horizontais), } \\
\text { de forma a proporcionar grande flexibilização de layouts. }\end{array}$} \\
\hline CM-POA & TR item 4.1 & \multicolumn{4}{|c|}{$\begin{array}{l}\text { ambientes integradores, criativos e acessíveis. A flexibilidade e } \\
\text { a inovação dos espaços devem refletir os aspectos conceituais } \\
\text { do projeto existente, onde, de certa forma, os espaços de } \\
\text { trabalho têm sempre uma relação com pátios internos ou } \\
\text { áreas externas de proporções generosas. }\end{array}$} \\
\hline $\begin{array}{l}\text { CAU-BR / } \\
\text { IAB-DF }\end{array}$ & Edital 11.10.II & \multicolumn{4}{|c|}{$\begin{array}{l}\text {... flexibilidade para ocupação e reorganização futura de } \\
\text { espaços, considerados os sistemas estruturais e de instalações } \\
\text { técnicas; }\end{array}$} \\
\hline $\begin{array}{l}\text { CODHAB- } \\
\text { CEB }\end{array}$ & TR item 6 & \multicolumn{4}{|c|}{$\begin{array}{l}\text { Os Projetos devem seguir as orientações do Programa de } \\
\text { Necessidades, que tem caráter sugestivo, devendo sempre } \\
\text { priorizar a flexibilidade ... }\end{array}$} \\
\hline $\begin{array}{l}\text { CODHAB- } \\
\text { CEF }\end{array}$ & TR item 6 & \multicolumn{4}{|c|}{$\begin{array}{l}\text { Os Projetos devem seguir as orientações do Programa de } \\
\text { Necessidades, que tem caráter sugestivo, devendo sempre } \\
\text { priorizar a flexibilidade ... }\end{array}$} \\
\hline $\begin{array}{l}\text { FATMA / } \\
\text { FAPESC }\end{array}$ & TR item 5 & \multicolumn{4}{|c|}{$\begin{array}{l}\text { redução do impacto negativo da edificação ao meio ambiente } \\
\text { através do uso racional de recursos na construção e operação } \\
\text { do edifício, proporcionando conforto ambiental aos usuários } \\
\text { gerando bem estar e aumento da produtividade e a } \\
\text { flexibilidade de usos. }\end{array}$} \\
\hline IAB-TO & $\begin{array}{c}\text { Edital item } \\
\text { 11.9.1.III }\end{array}$ & \multicolumn{4}{|c|}{$\begin{array}{l}\text { Organização do Conjunto - ... flexibilidade para ocupação e } \\
\text { reorganização futura de espaços. }\end{array}$} \\
\hline UFSCPA & $\begin{array}{l}\text { PB item } \\
\text { 5.2.1.b }\end{array}$ & \multicolumn{4}{|c|}{$\begin{array}{l}\text { Sempre que possível os espaços devem comportar certo nível } \\
\text { de flexibilidade de uso. Solicitam-se espaços que sejam } \\
\text { multifuncionais e que permitam modificar sua configuração de } \\
\text { forma rápida, com baixo custo. }\end{array}$} \\
\hline
\end{tabular}


Quadro 05: Aspectos Técnicos - Expansibilidade ou Adaptabilidade / Modalidade Concurso.

\begin{tabular}{|c|c|c|c|c|c|}
\hline \multicolumn{6}{|c|}{ SÍNTESE ACHADOS DE PESQUISA } \\
\hline Modalidade & $\begin{array}{l}\text { Concurso de } \\
\text { Projeto }\end{array}$ & Categoria & $\begin{array}{l}\text { Aspectos } \\
\text { Técnicos }\end{array}$ & Critério & $\begin{array}{l}\text { Expansibilidade / } \\
\text { Adaptabilidade }\end{array}$ \\
\hline Entidade & $\begin{array}{l}\text { Localização } \\
\text { Instrumento } \\
\text { Licitatório }\end{array}$ & \multicolumn{4}{|c|}{ Conteúdo } \\
\hline CA-MA & TR item 3 & \multicolumn{4}{|c|}{$\begin{array}{l}\text { Ampliar o Centro Administrativo, mediante novas construções } \\
\text { capazes de atender às demandas atuais e futuras de espaço } \\
\text { físico para o cumprimento da sua missão. }\end{array}$} \\
\hline $\begin{array}{l}\text { CODHAB- } \\
\text { CEB }\end{array}$ & TR item 6 & \multicolumn{4}{|c|}{$\begin{array}{l}\text {... adoção de sistemas que possibilitem expansão do projeto } \\
\text { até o limite do potencial construtivo do terreno. }\end{array}$} \\
\hline $\begin{array}{l}\text { CODHAB- } \\
\text { CEF }\end{array}$ & TR item 6 & \multicolumn{4}{|c|}{$\begin{array}{l}\text {... adoção de sistemas que possibilitem expansão do projeto } \\
\text { até o limite do potencial construtivo do terreno. }\end{array}$} \\
\hline $\begin{array}{l}\text { FATMA / } \\
\text { FAPESC }\end{array}$ & TR item 5.2 & \multicolumn{4}{|c|}{$\begin{array}{l}\text { É importante considerar no projeto características que } \\
\text { permitam ... possibilidade de fácil modificação, manutenção ou } \\
\text { substituição dos sistemas técnicos e de controle destes } \\
\text { sistemas ... }\end{array}$} \\
\hline IAB-TO & $\begin{array}{c}\text { Edital } \\
11.9 .1 . \mathrm{III}\end{array}$ & \multicolumn{4}{|c|}{$\begin{array}{l}\text { Organização do Conjunto - ... reorganização futura de espaços } \\
\text { considerados os sistemas estruturais e de instalações técnicas. }\end{array}$} \\
\hline
\end{tabular}

Quadro 06: Aspectos Técnicos - Interface entre os sistemas e componentes / Modalidade Concurso.

\begin{tabular}{|c|c|c|c|c|c|}
\hline \multicolumn{6}{|c|}{ SÍNTESE ACHADOS DE PESQUISA } \\
\hline Modalidade & $\begin{array}{l}\text { Concurso de } \\
\text { Projeto }\end{array}$ & Categoria & $\begin{array}{l}\text { Aspectos } \\
\text { Técnicos }\end{array}$ & Critério & $\begin{array}{c}\text { Interface entre os } \\
\text { sistemas }\end{array}$ \\
\hline Entidade & $\begin{array}{c}\text { Localização } \\
\text { Instrumento } \\
\text { Licitatório }\end{array}$ & \multicolumn{4}{|c|}{ Conteúdo } \\
\hline CM-POA & TR item 5.1 & \multicolumn{4}{|c|}{$\begin{array}{l}\text { métodos devem ser incorporados já na elaboração do partido } \\
\text { conceitual, incorporando um conjunto de sistemas que } \\
\text { funcionem harmonicamente com a composição arquitetônica } \\
\text { adotada. Através de um anteprojeto que apresente esta } \\
\text { preocupação desde o princípio antecipa-se uma série de } \\
\text { questões projetuais na fase da construção. }\end{array}$} \\
\hline $\begin{array}{l}\text { CAU-BR / } \\
\text { IAB-DF }\end{array}$ & $\begin{array}{l}\text { Edital item } \\
11.10 . \mathrm{VI}\end{array}$ & \multicolumn{4}{|c|}{$\begin{array}{l}\text {... entrosamento entre os sistemas e elementos técnicos do } \\
\text { conjunto arquitetônico... }\end{array}$} \\
\hline IAB-TO & $\begin{array}{l}\text { Edital item } \\
11.9 .1 . \mathrm{VI}\end{array}$ & \multicolumn{4}{|c|}{$\begin{array}{l}\text {... entrosamento entre os sistemas e elementos técnicos do } \\
\text { conjunto arquitetônico ... }\end{array}$} \\
\hline
\end{tabular}


Quadro 07: Aspectos Técnicos - Desmontagem e Remontagem / Modalidade Concurso.

\begin{tabular}{|c|c|c|c|c|c|}
\hline \multicolumn{6}{|c|}{ SÍNTESE ACHADOS DE PESQUISA } \\
\hline Modalidade & $\begin{array}{c}\text { Concurso de } \\
\text { Projeto }\end{array}$ & Categoria & $\begin{array}{l}\text { Aspectos } \\
\text { Técnicos }\end{array}$ & Critério & $\begin{array}{l}\text { Desmontagem } \\
\text { e Remontagem }\end{array}$ \\
\hline Entidade & $\begin{array}{l}\text { Localização - } \\
\text { Instrum. } \\
\text { Licitatório }\end{array}$ & \multicolumn{4}{|c|}{ Conteúdo } \\
\hline $\begin{array}{l}\text { FATMA / } \\
\text { FAPESC }\end{array}$ & TR item 4.V & \multicolumn{4}{|c|}{$\begin{array}{l}\text {... bom desempenho para o uso e função e para a saúde dos } \\
\text { usuários e seu entorno, demonstrando baixa manutenção e } \\
\text { eficiência na montagem e desmontagem dos sistemas e } \\
\text { materiais ... }\end{array}$} \\
\hline
\end{tabular}

Quadro 08: Aspectos Técnicos - Sistema Construtivo Industrializado / Modalidade Concurso.

\begin{tabular}{|c|c|c|c|c|c|}
\hline \multicolumn{6}{|c|}{ SÍNTESE ACHADOS DE PESQUISA } \\
\hline Modalidade & $\begin{array}{l}\text { Concurso de } \\
\text { Projeto }\end{array}$ & Categoria & $\begin{array}{l}\text { Aspectos } \\
\text { Técnicos }\end{array}$ & Critério & $\begin{array}{l}\text { Sistema Constr. } \\
\text { Industrializado }\end{array}$ \\
\hline Entidade & $\begin{array}{l}\text { Localização } \\
\text { Instrumento } \\
\text { Licitatório }\end{array}$ & \multicolumn{4}{|c|}{ Conteúdo } \\
\hline $\begin{array}{l}\text { CAU-BR / } \\
\text { IAB-DF }\end{array}$ & TR item 8.3 & \multicolumn{4}{|c|}{$\begin{array}{l}\text {... incorporando, sempre que possível, novas tecnologias que } \\
\text { acarretem em maior eficiência, em seus aspectos construtivo, } \\
\text { funcional e estético. }\end{array}$} \\
\hline CM-POA & TR item 5.I & \multicolumn{4}{|c|}{$\begin{array}{l}\text { Um sistema construtivo moderno e eficiente é, por exemplo, } \\
\text { aquele que minimiza ao máximo as quebras no momento da } \\
\text { construção. }\end{array}$} \\
\hline
\end{tabular}

Quadro 09: Aspectos Técnicos - Sistema Construtivo Racionalizado / Modalidade Concurso.

\begin{tabular}{|c|c|c|c|c|c|}
\hline \multicolumn{5}{|c|}{ SíNTESE ACHADOS DE PESQUISA } \\
\hline Modalidade & $\begin{array}{c}\text { Concurso de } \\
\text { Projeto }\end{array}$ & Categoria & $\begin{array}{c}\text { Aspectos } \\
\text { Técnicos }\end{array}$ & Critério & $\begin{array}{c}\text { Sistema Constr. } \\
\text { Racionalizado }\end{array}$ \\
\hline Entidade & $\begin{array}{c}\text { Localização - } \\
\text { Instrum. } \\
\text { Licitatório }\end{array}$ & \multicolumn{4}{|c|}{ Conteúdo } \\
\hline BNDES & Edital 7.1.c & $\begin{array}{l}\text { seguintes critérios objetivamente estipulados: (...) Sistema } \\
\text { Construtivo - (...) sistema construtivo racionalizado; }\end{array}$ \\
\hline CM-POA & TR item 5.I & $\begin{array}{l}\text { Um sistema construtivo moderno e eficiente é, por exemplo, } \\
\text { aquele que minimiza ao máximo as quebras no momento da } \\
\text { construção. }\end{array}$ \\
\hline
\end{tabular}


Quadro 10: Aspectos Técnicos - Manutenção / Modalidade Concurso.

\begin{tabular}{|c|c|c|c|c|c|}
\hline \multicolumn{6}{|c|}{ SÍNTESE ACHADOS DE PESQUISA } \\
\hline Modalidade & $\begin{array}{l}\text { Concurso de } \\
\text { Projeto }\end{array}$ & Categoria & $\begin{array}{l}\text { Aspectos } \\
\text { Técnicos }\end{array}$ & Critério & Manutenabilidade \\
\hline Entidade & $\begin{array}{l}\text { Localização } \\
\text { Instrumento } \\
\text { Licitatório } \\
\end{array}$ & \multicolumn{4}{|c|}{ onteúdo } \\
\hline $\mathrm{CA}-\mathrm{BH}$ & TR item 5.5 & \multicolumn{4}{|c|}{$\begin{array}{l}\text { As propostas devem contemplar materiais, sistemas e técnicas } \\
\text { construtivas que possibilitem a durabilidade e a redução dos } \\
\text { custos de construção e de manutenção dos projetos (...) }\end{array}$} \\
\hline CM-POA & TR item 5.1 & \multicolumn{4}{|c|}{$\begin{array}{l}\text { (...) prédio inteligente, que seja composto por um conjunto de } \\
\text { sistemas e técnicas construtivas pensadas em conjunto e de } \\
\text { forma a permitir uma excelente construção e manutenção do } \\
\text { objeto. Com relação a este último item, a otimização da } \\
\text { manutenção predial é indispensável, seja através de uma } \\
\text { técnica construtiva específica como de um sistema que permita } \\
\text { possíveis reparos de modo rápido e preferencialmente sem } \\
\text { quebras. }\end{array}$} \\
\hline $\begin{array}{l}\text { CAU-BR / } \\
\text { IAB-DF }\end{array}$ & TR item 2.4 & \multicolumn{4}{|c|}{$\begin{array}{l}\text { O custo do edifício ao longo do tempo, sua manutenção, a } \\
\text { facilidade para acesso e renovação das instalações (...) }\end{array}$} \\
\hline $\begin{array}{l}\text { CODHAB- } \\
\text { CEB }\end{array}$ & TR item 6§5은 & \multicolumn{4}{|c|}{$\begin{array}{l}\text { (...) serão analisadas: a adoção de soluções construtivas } \\
\text { racionais e eficientes, elegendo-se, sempre que possível, (...) a } \\
\text { adoção de soluções que ofereçam facilidades de operação e } \\
\text { manutenção dos diversos componentes e sistemas de } \\
\text { edificações (...) }\end{array}$} \\
\hline $\begin{array}{l}\text { CODHAB- } \\
\text { CEF }\end{array}$ & TR item 6§5을 & \multicolumn{4}{|c|}{$\begin{array}{l}\text { (...) serão analisadas: a adoção de soluções construtivas } \\
\text { racionais e eficientes, elegendo-se, sempre que possível, (...) a } \\
\text { adoção de soluções que ofereçam facilidades de operação e } \\
\text { manutenção dos diversos componentes e sistemas de } \\
\text { edificações (...) }\end{array}$} \\
\hline $\begin{array}{l}\text { FATMA / } \\
\text { FAPESC }\end{array}$ & TR item 4.V & \multicolumn{4}{|c|}{$\begin{array}{l}\text { (...) soluções mensuráveis que considerem os materiais e } \\
\text { sistemas construtivos utilizados pensando nas fases do ciclo de } \\
\text { vida e durante o período de uso da edificação. De forma a } \\
\text { assegurar o bom desempenho para o uso e função e para a } \\
\text { saúde dos usuários e seu entorno, demonstrando baixa } \\
\text { manutenção. }\end{array}$} \\
\hline IAB-TO & TR item 5.3 & \multicolumn{4}{|c|}{$\begin{array}{l}\text { (...) É também importante a escolha de materiais comerciais } \\
\text { facilmente disponíveis nas proximidades do canteiro, evitando- } \\
\text { se assim longos percursos de transporte. }\end{array}$} \\
\hline
\end{tabular}


Quadro 11: Aspectos Técnicos - Disponibilidade Local dos sistemas / Modalidade Concurso

\begin{tabular}{|c|c|c|c|c|c|}
\hline \multicolumn{6}{|c|}{ SÍNTESE ACHADOS DE PESQUISA } \\
\hline Modalidade & $\begin{array}{l}\text { Concurso de } \\
\text { Projeto }\end{array}$ & Categoria & $\begin{array}{l}\text { Aspectos } \\
\text { Técnicos }\end{array}$ & Critério & $\begin{array}{c}\text { Disponibilidade } \\
\text { Local dos Sistemas }\end{array}$ \\
\hline Entidade & $\begin{array}{l}\text { Localização } \\
\text { Instrumento } \\
\text { Licitatório }\end{array}$ & \multicolumn{4}{|c|}{ Conteúdo } \\
\hline $\begin{array}{l}\text { FATMA / } \\
\text { FAPESC }\end{array}$ & TR item 5.2 & \multicolumn{4}{|c|}{$\begin{array}{l}\text { Utilizar materiais locais ou regionais que tenham menor } \\
\text { consumo energético por conta do transporte (desde que } \\
\text { possuam alta qualidade e propiciem uma menor manutenção); }\end{array}$} \\
\hline CM-POA & TR item 5.3 & \multicolumn{4}{|c|}{$\begin{array}{l}\text { (...) É também importante a escolha de materiais comerciais } \\
\text { facilmente disponíveis nas proximidades do canteiro, evitando- } \\
\text { se assim longos percursos de transporte. }\end{array}$} \\
\hline
\end{tabular}




\section{APÊNDICE B}

Quadro 01: Aspectos Ambientais - ACV / Modalidade Concurso

\begin{tabular}{|c|c|c|c|c|c|}
\hline \multicolumn{6}{|c|}{ SÍNTESE ACHADOS DE PESQUISA } \\
\hline Modalidade & $\begin{array}{l}\text { Concurso de } \\
\text { Projeto }\end{array}$ & Categoria & $\begin{array}{l}\text { Aspectos } \\
\text { Ambientais }\end{array}$ & Critério & ACV \\
\hline Entidade & $\begin{array}{l}\text { Localização } \\
\text { Instrumento } \\
\text { Licitatório } \\
\end{array}$ & \multicolumn{4}{|c|}{ Conteúdo } \\
\hline $\begin{array}{l}\text { FATMA / } \\
\text { FAPESC }\end{array}$ & TR item 4.V & \multicolumn{4}{|c|}{$\begin{array}{l}\text { apresentar soluções mensuráveis que considerem os } \\
\text { materiais e sistemas construtivos utilizados pensando nas } \\
\text { fases do ciclo de vida e durante o período de uso da } \\
\text { edificação. (...) }\end{array}$} \\
\hline
\end{tabular}

Quadro 02: Aspectos Ambientais - Utilização de Materiais e componentes reciclados / Modalidade Concurso

\begin{tabular}{|c|c|c|c|c|c|}
\hline \multicolumn{6}{|c|}{ SÍNTESE ACHADOS DE PESQUISA } \\
\hline Modalidade & $\begin{array}{l}\text { Concurso de } \\
\text { Projeto }\end{array}$ & Categoria & $\begin{array}{l}\text { Aspectos } \\
\text { Ambientais }\end{array}$ & Critério & $\begin{array}{l}\text { Utilização de } \\
\text { Mat. / Comp. } \\
\text { Reciclados }\end{array}$ \\
\hline Entidade & $\begin{array}{l}\text { Localização } \\
\text { Instrumento } \\
\text { Licitatório }\end{array}$ & \multicolumn{4}{|c|}{ Conteúdo } \\
\hline \multirow[t]{2}{*}{ IAB-TO } & TR item 5.6 & \multicolumn{4}{|c|}{$\begin{array}{l}\text { Na escolha dos materiais, a preferência deve ser dada } \\
\text { àqueles que tenham certificação ambiental ou selo } \\
\text { ecológico, de manejo sustentável e reciclável. Os materiais } \\
\text { não convencionais (chamados muitas vezes de } \\
\text { alternativos), como os reciclados, são aqueles que em sua } \\
\text { composição possuem uma porcentagem de material } \\
\text { reciclado, de origem do mesmo produto ou de outra } \\
\text { origem, porém aproveitado na execução do material (...) }\end{array}$} \\
\hline & TR item 5.3 & \multicolumn{4}{|c|}{$\begin{array}{l}\text { seja dada a preferência a materiais recicláveis ou que } \\
\text { contenham componentes reciclados. }\end{array}$} \\
\hline
\end{tabular}


Quadro 03: Aspectos Ambientais - Utilização de Materiais e componentes recicláveis / Modalidade Concurso

\begin{tabular}{|c|c|c|c|c|c|}
\hline \multicolumn{6}{|c|}{ SÍNTESE ACHADOS DE PESQUISA } \\
\hline Modalidade & $\begin{array}{l}\text { Concurso de } \\
\text { Projeto }\end{array}$ & Categoria & $\begin{array}{l}\text { Aspectos } \\
\text { Ambientais }\end{array}$ & Critério & $\begin{array}{l}\text { Utilização de } \\
\text { Mat. / Comp. } \\
\text { Recicláveis }\end{array}$ \\
\hline Entidade & $\begin{array}{c}\text { Localização } \\
\text { Instrumento } \\
\text { Licitatório }\end{array}$ & \multicolumn{4}{|c|}{ Conteúdo } \\
\hline CA-MA & TR item 4.1 & \multicolumn{4}{|c|}{$\begin{array}{l}\text { A redução do impacto ambiental do Complexo, em todas as } \\
\text { fases de sua produção e utilização, deve ser um princípio } \\
\text { norteador do projeto que deverá adotar estratégias } \\
\text { arquitetônicas que promovam o uso racional da água e da } \\
\text { energia, e favoreçam a reciclagem dos materiais utilizados, a } \\
\text { coleta seletiva e a destinação adequada dos resíduos } \\
\text { produzidos. (...) }\end{array}$} \\
\hline $\mathrm{CA}-\mathrm{BH}$ & TR item 5.6 & \multicolumn{4}{|c|}{$\begin{array}{l}\text { As propostas devem adotar estratégias que promovam o uso } \\
\text { racional da água e da energia, e favoreçam a reciclagem dos } \\
\text { materiais utilizados (...) }\end{array}$} \\
\hline $\begin{array}{l}\text { FATMA / } \\
\text { FAPESC }\end{array}$ & TR item 5.2 & \multicolumn{4}{|c|}{$\begin{array}{l}\text { promoção da reciclagem e correto gerenciamento de } \\
\text { resíduos dentro da edificação. }\end{array}$} \\
\hline IAB-TO & TR item 5.3 & \multicolumn{4}{|c|}{$\begin{array}{l}\text { seja dada a preferência a materiais recicláveis ou que } \\
\text { contenham componentes reciclados. }\end{array}$} \\
\hline
\end{tabular}

Quadro 04: Aspectos Ambientais - Utilização de Materiais e componentes reutilizáveis / Modalidade Concurso

\begin{tabular}{|c|c|c|c|c|c|}
\hline \multicolumn{6}{|c|}{ SÍNTESE ACHADOS DE PESQUISA } \\
\hline Modalidade & $\begin{array}{l}\text { Concurso de } \\
\text { Projeto }\end{array}$ & Categoria & $\begin{array}{l}\text { Aspectos } \\
\text { Ambientais }\end{array}$ & Critério & $\begin{array}{l}\text { Utilização de Mat. / } \\
\text { Comp. Reutilizáveis }\end{array}$ \\
\hline Entidade & $\begin{array}{l}\text { Localização } \\
\text { Instrumento } \\
\text { Licitatório } \\
\end{array}$ & \multicolumn{4}{|c|}{ Conteúdo } \\
\hline $\begin{array}{l}\text { FATMA / } \\
\text { FAPESC }\end{array}$ & TR item 5.2 & \multicolumn{4}{|c|}{$\begin{array}{l}\text { Utilizar materiais e sistemas construtivos com alto valor de } \\
\text { reciclagem ou reutilização e cujo descarte não seja prejudicial } \\
\text { ao meio ambiente; }\end{array}$} \\
\hline
\end{tabular}


Quadro 05: Aspectos Ambientais - Gestão de Resíduos / Modalidade Concurso

\begin{tabular}{|c|c|c|c|c|c|}
\hline \multicolumn{6}{|c|}{ SÍNTESE ACHADOS DE PESQUISA } \\
\hline Modalidade & $\begin{array}{l}\text { Concurso de } \\
\text { Projeto }\end{array}$ & Categoria & $\begin{array}{l}\text { Aspectos } \\
\text { Ambientais }\end{array}$ & Critério & $\begin{array}{l}\text { Gestão de } \\
\text { Resíduos }\end{array}$ \\
\hline Entidade & $\begin{array}{l}\text { Localização } \\
\text { Instrumento } \\
\text { Licitatório }\end{array}$ & \multicolumn{4}{|c|}{ Conteúdo } \\
\hline BNDES & $\begin{array}{l}\text { Edital item } \\
\text { 7.1.e }\end{array}$ & \multicolumn{4}{|c|}{ (...) redução de perdas construtivas (...) } \\
\hline CA-MA & TR item 4.1 & \multicolumn{4}{|c|}{$\begin{array}{l}\text { (...) deve ser um princípio norteador do projeto que deverá } \\
\text { adotar estratégias arquitetônicas que promovam o uso } \\
\text { racional da água e da energia, e favoreçam a reciclagem dos } \\
\text { materiais utilizados, a coleta seletiva e a destinação adequada } \\
\text { dos resíduos produzidos. }\end{array}$} \\
\hline $\mathrm{CA}-\mathrm{BH}$ & TR item 5.6 & \multicolumn{4}{|c|}{ (...) destinação adequada dos resíduos produzidos. (...) } \\
\hline CM-POA & TR item 5.1 & \multicolumn{4}{|c|}{$\begin{array}{l}\text { (...) técnica construtiva específica como de um sistema que } \\
\text { permita possíveis reparos de modo rápido e preferencialmente } \\
\text { sem quebras. }\end{array}$} \\
\hline $\begin{array}{l}\text { CAU-BR / } \\
\text { IAB-DF }\end{array}$ & $\begin{array}{l}\text { Edital item } \\
\text { 11.10.VII } \\
\end{array}$ & \multicolumn{4}{|c|}{ (...) ; redução de perdas construtivas; (...) } \\
\hline FATMA / & TR item 4.IV - & \multicolumn{4}{|c|}{$\begin{array}{l}\text { (...), e a máxima redução de resíduos e descartes e transporte } \\
\text { inteligente. }\end{array}$} \\
\hline FAPESC & TR item 5.2 & \multicolumn{4}{|c|}{$\begin{array}{l}\text { promoção da reciclagem e correto gerenciamento de resíduos } \\
\text { dentro da edificação }\end{array}$} \\
\hline IAB-TO & TR item 5.7 & \multicolumn{4}{|c|}{$\begin{array}{l}\text { (...) durante a elaboração do Projeto, para o Processo de } \\
\text { Gerenciamento de Resíduos de Construção e Demolição - RCD } \\
\text { devem ser levados em consideração as legislações em níveis } \\
\text { Nacional, Estadual e Municipal vigentes. }\end{array}$} \\
\hline
\end{tabular}


Quadro 01: Aspectos Socioeconômicos - Custo da Construção (Economicidade) / Modalidade Concurso

\begin{tabular}{|c|c|c|c|c|c|}
\hline \multicolumn{6}{|c|}{ SÍNTESE ACHADOS DE PESQUISA } \\
\hline Modalidade & $\begin{array}{l}\text { Concurso de } \\
\text { Projeto }\end{array}$ & Categoria & $\begin{array}{c}\text { Aspectos } \\
\text { Socioeconômicos }\end{array}$ & Critério & $\begin{array}{c}\text { Custo } \\
\text { Construção } \\
\text { (economicidade) }\end{array}$ \\
\hline Entidade & $\begin{array}{l}\text { Localização } \\
\text { Instrumento } \\
\text { Licitatório }\end{array}$ & \multicolumn{4}{|c|}{ Conteúdo } \\
\hline BNDES & $\begin{array}{l}\text { Edital item } \\
\text { 7.1.b }\end{array}$ & \multicolumn{4}{|c|}{$\begin{array}{l}\text { uso de técnica construtiva geral que vise à economicidade e à } \\
\text { exequibilidade (...) }\end{array}$} \\
\hline CA-MA & TR item 3 & \multicolumn{4}{|c|}{$\begin{array}{l}\text { (...) proposta mais adequada quanto aos aspectos de projeto } \\
\text { arquitetônico, (...) custo, viabilidade técnica e adequação (...) }\end{array}$} \\
\hline $\mathrm{CA}-\mathrm{BH}$ & TR item 5.5 & \multicolumn{4}{|c|}{$\begin{array}{l}\text { (...) As propostas devem contemplar materiais, sistemas e } \\
\text { técnicas construtivas que possibilitem a durabilidade e a } \\
\text { redução dos custos de construção (...) }\end{array}$} \\
\hline $\begin{array}{l}\text { CAU-BR / } \\
\text { IAB-DF }\end{array}$ & TR item 8.3.VI & \multicolumn{4}{|c|}{$\begin{array}{l}\text { Privilegiar a agilidade construtiva, a economicidade e a } \\
\text { facilidade de manutenção. }\end{array}$} \\
\hline CODHAB-CEB & TR item 6 & \multicolumn{4}{|c|}{$\begin{array}{l}\text { (...) as soluções arquitetônicas devem privilegiar a } \\
\text { economicidade e a agilidade construtiva }\end{array}$} \\
\hline CODHAB-CEF & TR item 6 & \multicolumn{4}{|c|}{$\begin{array}{l}\text { (...) as soluções arquitetônicas devem privilegiar a } \\
\text { economicidade e a agilidade construtiva }\end{array}$} \\
\hline $\begin{array}{l}\text { FATMA / } \\
\text { FAPESC }\end{array}$ & TR item 7 & \multicolumn{4}{|c|}{$\begin{array}{l}\text { O custo para o empreendimento deverá ser de } \mathrm{R} \$ 2.000 .00 \\
\text { (dois mil reais) por metro quadrado em média, sendo que o } \\
\text { valor total não poderá ultrapassar } \mathrm{R} \$ 19.200 .000,00 \\
\text { (dezenove milhões e duzentos mil reais). (...) }\end{array}$} \\
\hline UFCSPA & $\begin{array}{l}\text { Edital item } \\
\text { 9.3.c }\end{array}$ & \multicolumn{4}{|c|}{ Viabilidade técnico-construtiva e econômica da proposta (...) } \\
\hline
\end{tabular}


Quadro 02: Aspectos Socioeconômicos - Custo do Ciclo de Vida / Modalidade Concurso

\begin{tabular}{|c|c|c|c|c|c|}
\hline \multicolumn{6}{|c|}{ SÍNTESE ACHADOS DE PESQUISA } \\
\hline Modalidade & $\begin{array}{c}\text { Concurso de } \\
\text { Projeto }\end{array}$ & Categoria & $\begin{array}{c}\text { Aspectos } \\
\text { Socioeconômicos }\end{array}$ & Critério & $\begin{array}{l}\text { Custo de Ciclo } \\
\text { de Vida }\end{array}$ \\
\hline Entidade & \begin{tabular}{|c|} 
Localização \\
Instrumento \\
Licitatório \\
\end{tabular} & \multicolumn{4}{|c|}{ Conteúdo } \\
\hline $\mathrm{CA}-\mathrm{BH}$ & TR item 5.7 & \multicolumn{4}{|c|}{$\begin{array}{l}\text { As propostas devem apresentar viabilidade econômica para sua } \\
\text { implementação e baixos custos de manutenção, sem prejuízo da } \\
\text { qualidade de sua arquitetura. }\end{array}$} \\
\hline CM-POA & TR item 5.1 & \multicolumn{4}{|c|}{$\begin{array}{l}\text { a otimização da manutenção predial é indispensável, seja } \\
\text { através de uma técnica construtiva específica como de um } \\
\text { sistema que permita possíveis reparos de modo rápido e } \\
\text { preferencialmente sem quebras. Esta preocupação evidencia-se } \\
\text { como uma sustentabilidade tanto econômica quanto ambiental } \\
\text { (...) }\end{array}$} \\
\hline $\begin{array}{l}\text { CAU-BR / } \\
\text { IAB-DF }\end{array}$ & TR item 2.4 & \multicolumn{4}{|c|}{$\begin{array}{l}\text { O custo do edifício ao longo do tempo, sua manutenção, a } \\
\text { facilidade para acesso e renovação das instalações, a facilidade } \\
\text { para adequação do edifício para novas funções (...) }\end{array}$} \\
\hline $\begin{array}{l}\text { FATMA / } \\
\text { FAPESC }\end{array}$ & TR item 5.2 & \multicolumn{4}{|c|}{$\begin{array}{l}\text { Utilizar sistemas construtivos que propiciem flexibilidade na } \\
\text { mudança de usos e que propiciem um menor custo na } \\
\text { manutenção da edificação; }\end{array}$} \\
\hline
\end{tabular}




\section{APÊNDICE D}

Quadro 01: Aspectos Técnicos - Prazo de Construção / Modalidade Concorrência

\begin{tabular}{|c|c|c|c|c|c|}
\hline \multicolumn{6}{|c|}{ SÍNTESE ACHADOS DE PESQUISA } \\
\hline Modalidade & Concorrência & Categoria & $\begin{array}{l}\text { Aspectos } \\
\text { Técnicos }\end{array}$ & Critério & $\begin{array}{l}\text { Prazo de } \\
\text { Construção }\end{array}$ \\
\hline Entidade & $\begin{array}{l}\text { Localização } \\
\text { Instrumento } \\
\text { Licitatório }\end{array}$ & \multicolumn{4}{|c|}{ Conteúdo } \\
\hline ENAP & $\begin{array}{l}\text { PB item } \\
5.4 .1 .32\end{array}$ & \multicolumn{4}{|c|}{$\begin{array}{l}\text { (...)será levada em conta a possibilidade de substituição de } \\
\text { serviços artesanais por elementos industrializados para reduzir } \\
\text { prazos e custos de construção. }\end{array}$} \\
\hline IFTM & TR item 7 & \multicolumn{4}{|c|}{$\begin{array}{l}\text { A contratada deverá apresentar uma proposta de concepção } \\
\text { em linhas gerais, oferecendo, para discussão, alternativas a } \\
\text { respeito dos métodos e técnicas a serem utilizados na } \\
\text { construção, bem como o prazo de execução do } \\
\text { empreendimento, com vistas à escolha da solução mais viável } \\
\text { sob os aspectos técnico e econômico. }\end{array}$} \\
\hline UESPI-CM & TR item 4 & \multicolumn{4}{|c|}{$\begin{array}{l}\text { Os empreendimentos deverão ser planejados e concebidos de } \\
\text { forma a utilizar as novas tecnologias de materiais existentes no } \\
\text { mercado, com a finalidade de aperfeiçoar o tempo de } \\
\text { construção (...) }\end{array}$} \\
\hline UESPI-TN & TR item 4 & \multicolumn{4}{|c|}{$\begin{array}{l}\text { Os empreendimentos deverão ser planejados e concebidos de } \\
\text { forma a utilizar as novas tecnologias de materiais existentes no } \\
\text { mercado, com a finalidade de aperfeiçoar o tempo de } \\
\text { construção (...) }\end{array}$} \\
\hline
\end{tabular}


Quadro 02: Aspectos Técnicos - Produtividade / Modalidade Concorrência

\begin{tabular}{|c|c|c|c|c|c|}
\hline \multicolumn{6}{|c|}{ SÍNTESE ACHADOS DE PESQUISA } \\
\hline Modalidade & Concorrência & Categoria & $\begin{array}{l}\text { Aspectos } \\
\text { Técnicos }\end{array}$ & Critério & Produtividade \\
\hline Entidade & $\begin{array}{l}\text { Localização } \\
\text { Instrumento } \\
\text { Licitatório }\end{array}$ & \multicolumn{4}{|c|}{ Conteúdo } \\
\hline AL-CE & $\begin{array}{c}\text { TR item } \\
3.74 .3\end{array}$ & \multicolumn{4}{|c|}{$\begin{array}{l}\text { Adoção soluções construtivas racionais elegendo, na medida do } \\
\text { possível, sistemas de modulação (com projeção de possível } \\
\text { ampliação) e padronização compatíveis com as características } \\
\text { do empreendimento; }\end{array}$} \\
\hline ENAP & $\begin{array}{l}\text { PB item } \\
\text { 5.4.1.35.f }\end{array}$ & \multicolumn{4}{|c|}{$\begin{array}{l}\text { Facilidade de execução, de conservação e manutenção dos } \\
\text { materiais escolhidos; }\end{array}$} \\
\hline IFTM & TR item 6 & \multicolumn{4}{|c|}{$\begin{array}{l}\text { Adotar solução construtiva racional, elegendo sempre que } \\
\text { possível sistema de modulação e padronização compatíveis com } \\
\text { as características do empreendimento; }\end{array}$} \\
\hline PGM-POA & TR item 6.1 .8 & \multicolumn{4}{|c|}{$\begin{array}{l}\text { Adotar solução construtiva racional elegendo, sempre que } \\
\text { possível, sistemas de modulação e padronização, compatíveis } \\
\text { com as características do empreendimento, oferecendo } \\
\text { facilidades de operação e manutenção dos diversos } \\
\text { componentes e sistemas da edificação. A premissa básica para o } \\
\text { sistema construtivo é sua rapidez executiva aliada ao custo } \\
\text { otimizado. }\end{array}$} \\
\hline STM & TR item 6.e & \multicolumn{4}{|c|}{$\begin{array}{l}\text { Adoção soluções construtivas racionais elegendo, sempre que } \\
\text { possível, sistemas de modulação e padronização compatíveis } \\
\text { com as características da edificação; }\end{array}$} \\
\hline TJ-RO & ET item 1.e & \multicolumn{4}{|c|}{$\begin{array}{l}\text { Adoção soluções construtivas racionais elegendo, sempre que } \\
\text { possível, sistemas de modulação e padronização compatíveis } \\
\text { com as características da edificação; }\end{array}$} \\
\hline UESPI-CM & TR item 6 & \multicolumn{4}{|c|}{$\begin{array}{l}\text { A Licitante vencedora deverá elaborar os trabalhos } \\
\text { considerando sempre a qualidade dos projetos, os requisitos de } \\
\text { segurança funcionalidade, adequação ao interesse público, } \\
\text { economia, facilidade na execução da obra (...) }\end{array}$} \\
\hline UESPI-TN & TR item 6 & \multicolumn{4}{|c|}{$\begin{array}{l}\text { A Licitante vencedora deverá elaborar os trabalhos } \\
\text { considerando sempre a qualidade dos projetos, os requisitos de } \\
\text { segurança funcionalidade, adequação ao interesse público, } \\
\text { economia, facilidade na execução da obra (...) }\end{array}$} \\
\hline UFU & PB item 2 & \multicolumn{4}{|c|}{ Facilidade na execução, conservação e operação; } \\
\hline
\end{tabular}


Quadro 03: Aspectos Técnicos - Qualidade / Modalidade Concorrência

\begin{tabular}{|c|c|c|c|c|c|}
\hline \multicolumn{6}{|c|}{ SÍNTESE ACHADOS DE PESQUISA } \\
\hline Modalidade & Concorrência & Categoria & $\begin{array}{l}\text { Aspectos } \\
\text { Técnicos }\end{array}$ & Critério & Qualidade \\
\hline Entidade & $\begin{array}{l}\text { Localização - } \\
\text { Instrum. } \\
\text { Licitatório }\end{array}$ & \multicolumn{4}{|c|}{ Conteúdo } \\
\hline ENAP & PB item 5.4.1.34 & \multicolumn{4}{|c|}{$\begin{array}{l}\text { A inclusão de elementos padronizados no projeto, além de } \\
\text { melhorar cada vez mais a qualidade da construção pela } \\
\text { repetição das operações, proporciona um suporte ideal } \\
\text { para a manutenção da edificação ou elemento urbano, } \\
\text { racionalizando estoques e facilitando o manuseio e troca } \\
\text { de componentes. }\end{array}$} \\
\hline STM & PB item 10.c & \multicolumn{4}{|c|}{$\begin{array}{l}\text { As especificações de serviços deverão considerar (...) } \\
\text { Acabamento superficial; }\end{array}$} \\
\hline TJ-RO & ET item 1.e & \multicolumn{4}{|c|}{$\begin{array}{l}\text { Adoção soluções construtivas racionais elegendo, sempre } \\
\text { que possível, sistemas de modulação e padronização } \\
\text { compatíveis com as características da edificação; }\end{array}$} \\
\hline
\end{tabular}

Quadro 04: Aspectos Técnicos - Flexibilidade / Modalidade Concorrência

\begin{tabular}{|c|c|c|c|c|c|}
\hline \multicolumn{6}{|c|}{ SÍNTESE ACHADOS DE PESQUISA } \\
\hline Modalidade & Concorrência & Categoria & $\begin{array}{l}\text { Aspectos } \\
\text { Técnicos }\end{array}$ & Critério & Flexibilidade \\
\hline Entidade & $\begin{array}{l}\text { Localização - } \\
\text { Instrum. } \\
\text { Licitatório } \\
\end{array}$ & \multicolumn{4}{|c|}{ Conteúdo } \\
\hline $\mathrm{AL}-\mathrm{CE}$ & TR item 3.7.4.f & \multicolumn{4}{|c|}{$\begin{array}{l}\text { Adoção de soluções flexíveis e versáteis nas áreas } \\
\text { destinadas às atividades comuns e públicas }\end{array}$} \\
\hline ENAP & $\begin{array}{l}\text { PB item } \\
\text { 5.4.1.47.d }\end{array}$ & \multicolumn{4}{|c|}{$\begin{array}{l}\text { Espaços flexíveis, maleabilidade/flexibilidade de tamanho e } \\
\text { configuração de sala para atender aos diversos perfis das } \\
\text { áreas e equipes (...) }\end{array}$} \\
\hline PGM-POA & TR item 6.1 .8 & \multicolumn{4}{|c|}{$\begin{array}{l}\text { Deverá prever laje livre, de forma a atender espaços } \\
\text { compartimentados (fechados) definidos por divisórias leves } \\
\text { e espaços compartimentados abertos definidos por } \\
\text { divisórias autoportantes para as atividades de apoio das } \\
\text { diversas equipes (...) }\end{array}$} \\
\hline STM & PB item $6 . f$ & \multicolumn{4}{|c|}{$\begin{array}{l}\text { Adoção de soluções flexíveis e versáteis nas áreas } \\
\text { destinadas às atividades comuns e públicas; }\end{array}$} \\
\hline TJ-RO & ET item 1.e & \multicolumn{4}{|c|}{$\begin{array}{l}\text { Adoção de soluções flexíveis e versáteis e resistentes nas } \\
\text { áreas destinadas às atividades comuns e públicas; }\end{array}$} \\
\hline
\end{tabular}


Quadro 05: Aspectos Técnicos - Expansibilidade ou Adaptabilidade / Modalidade Concorrência

\begin{tabular}{|c|c|c|c|c|c|}
\hline \multicolumn{6}{|c|}{ SÍNTESE ACHADOS DE PESQUISA } \\
\hline Modalidade & Concorrência & Categoria & $\begin{array}{l}\text { Aspectos } \\
\text { Técnicos }\end{array}$ & Critério & $\begin{array}{l}\text { Expansibilidade / } \\
\text { Adaptabilidade }\end{array}$ \\
\hline Entidade & \begin{tabular}{|c|} 
Localização \\
Instrumento \\
Licitatório \\
\end{tabular} & \multicolumn{4}{|c|}{ Conteúdo } \\
\hline AL-CE & $\begin{array}{l}\text { TR item } \\
\text { 3.7.4.e }\end{array}$ & \multicolumn{4}{|c|}{$\begin{array}{l}\text { Adoção soluções construtivas racionais elegendo, na medida do } \\
\text { possível, sistemas de modulação (com projeção de possível } \\
\text { ampliação) e padronização compatíveis com as características do } \\
\text { empreendimento; }\end{array}$} \\
\hline PGM-POA & TR item 6.1 .3 & \multicolumn{4}{|c|}{$\begin{array}{l}\text { projeto arquitetônico para a sede da PGM deverá ser proposto de } \\
\text { forma a atender às equipes especificadas, quantificadas e com } \\
\text { suas relações de trabalho constantes no Anexo B, bem como ser } \\
\text { pensado considerando a previsão de expansão futura (...) }\end{array}$} \\
\hline
\end{tabular}

Quadro 06: Aspectos Técnicos - Interface entre os sistemas / Modalidade Concorrência

\begin{tabular}{|c|c|c|c|c|c|}
\hline \multicolumn{6}{|c|}{ SÍNTESE ACHADOS DE PESQUISA } \\
\hline Modalidade & Concorrência & Categoria & $\begin{array}{l}\text { Aspectos } \\
\text { Técnicos }\end{array}$ & Critério & $\begin{array}{l}\text { Interface entre os } \\
\text { sistemas }\end{array}$ \\
\hline Entidade & $\begin{array}{l}\text { Localização- } \\
\text { Instrumento } \\
\text { Licitatório }\end{array}$ & \multicolumn{4}{|c|}{ Conteúdo } \\
\hline AL-CE: & $\begin{array}{l}\text { TR item } \\
\text { 3.7.4.e }\end{array}$ & \multicolumn{4}{|c|}{$\begin{array}{l}\text { Todos os estudos e projetos deverão desenvolver-se de forma } \\
\text { harmônica, consistente e coordenada, observando a não } \\
\text { interferência entre os elementos dos diversos sistemas da } \\
\text { edificação (...) }\end{array}$} \\
\hline ENAP & $\begin{array}{l}\text { PB item } \\
5.4 .1 .41\end{array}$ & \multicolumn{4}{|c|}{$\begin{array}{l}\text { Os arremates devem compatibilizar materiais diferentes que } \\
\text { não podem ser ligados diretamente sem interferir no } \\
\text { desempenho do sistema, bem como permitir acomodações para } \\
\text { as diferenças de dilatação dos materiais. }\end{array}$} \\
\hline IFTM & TR item 6 & \multicolumn{4}{|c|}{$\begin{array}{l}\text { Todos os estudos e projetos deverão ser desenvolvidos de forma } \\
\text { harmônica e consistente, observando a não-interferência entre } \\
\text { os elementos dos diversos sistemas da edificação (...) }\end{array}$} \\
\hline STM & TR item 6 & \multicolumn{4}{|c|}{$\begin{array}{l}\text { Todos os estudos e projetos deverão ser desenvolvidos de forma } \\
\text { harmônica, consistente e coordenada, observando a não } \\
\text { interferência entre os elementos dos diversos sistemas da } \\
\text { edificação(...) }\end{array}$} \\
\hline TJ-RO & $\begin{array}{l}\text { Edital item } \\
\quad 11.17\end{array}$ & \multicolumn{4}{|c|}{$\begin{array}{l}\text { Coordenar a conceituação e a caracterização, de forma clara, de } \\
\text { todos os elementos do projeto do empreendimento, com as } \\
\text { definições de projeto necessárias a todos os agentes nele } \\
\text { envolvidos, resultando em Projetos (Básico e Executivo) sem } \\
\text { problemas de integridade. }\end{array}$} \\
\hline
\end{tabular}


Quadro 07: Aspectos Técnicos - Sist. Constr. Industrializados / Mod. Concorrência

\begin{tabular}{|c|c|c|c|c|c|}
\hline \multicolumn{6}{|c|}{ SÍNTESE ACHADOS DE PESQUISA } \\
\hline Modalidade & Concorrência & Categoria & $\begin{array}{l}\text { Aspectos } \\
\text { Técnicos }\end{array}$ & Critério & $\begin{array}{l}\text { Sistema Constr. } \\
\text { Industrializado }\end{array}$ \\
\hline Entidade & $\begin{array}{c}\text { Localização } \\
\text { Instrumento } \\
\text { Licitatório }\end{array}$ & \multicolumn{4}{|c|}{ Conteúdo } \\
\hline ENAP & $\begin{array}{l}\text { PB item } \\
5.4 .1 .41\end{array}$ & \multicolumn{4}{|c|}{$\begin{array}{l}\text { A evolução tecnológica dos materiais deverá ser considerada para } \\
\text { garantir melhor qualidade e desempenho nos serviços e produtos } \\
\text { de uma edificação. Além disso, também será levada em conta a } \\
\text { possibilidade de substituição de serviços artesanais por elementos } \\
\text { industrializados para reduzir prazos e custos de construção. }\end{array}$} \\
\hline PGM-POA & $\begin{array}{l}\text { TR item } \\
6.1 .11\end{array}$ & \multicolumn{4}{|c|}{ pré-fabricação na construção. } \\
\hline
\end{tabular}

Quadro 08: Aspectos Técnicos - Operação eficiente / Modalidade Concorrência

\begin{tabular}{|c|c|c|c|c|c|}
\hline \multicolumn{6}{|c|}{ SÍNTESE ACHADOS DE PESQUISA } \\
\hline Modalidade & Concorrência & Categoria & $\begin{array}{l}\text { Aspectos } \\
\text { Técnicos }\end{array}$ & Critério & $\begin{array}{l}\text { Operação eficiente } \\
\text { empreendimento }\end{array}$ \\
\hline Entidade & $\begin{array}{l}\text { Localização } \\
\text { Instrumento } \\
\text { Licitatório }\end{array}$ & \multicolumn{4}{|c|}{ Conteúdo } \\
\hline $\mathrm{AL}-\mathrm{CE}$ & TR item 3.7.4 & \multicolumn{4}{|c|}{$\begin{array}{l}\text { Adoção de soluções que ofereçam facilidade de operação e } \\
\text { manutenção dos diversos componentes e sistemas da edificação. }\end{array}$} \\
\hline ENAP & $\begin{array}{l}\text { PB item } \\
\text { 5.4.1.35.f }\end{array}$ & \multicolumn{4}{|c|}{$\begin{array}{l}\text { Facilidade na execução, conservação e manutenção dos materiais } \\
\text { escolhidos; }\end{array}$} \\
\hline IFTM & TR item 6 & \multicolumn{4}{|c|}{$\begin{array}{l}\text { Adotar soluções que ofereçam facilidades de operação e } \\
\text { manutenção dos diversos componentes e sistemas da edificação; }\end{array}$} \\
\hline PGM-POA & TR item 6.1 .9 & \multicolumn{4}{|c|}{$\begin{array}{l}\text { Adotar soluções que ofereçam facilidades de operação e } \\
\text { manutenção dos diversos componentes e sistemas da edificação; }\end{array}$} \\
\hline STM & PB item 6.g & \multicolumn{4}{|c|}{$\begin{array}{l}\text { Adoção de soluções que ofereçam facilidade de operação e } \\
\text { manutenção dos diversos componentes e sistemas da edificação; }\end{array}$} \\
\hline TJ-RO & ET item 1.g & \multicolumn{4}{|c|}{$\begin{array}{l}\text { Adoção de soluções que ofereçam facilidade de operação e } \\
\text { manutenção dos diversos componentes e sistemas da edificação; }\end{array}$} \\
\hline UESPI-CM & TR item 6 & \multicolumn{4}{|c|}{$\begin{array}{l}\text { A Licitante vencedora deverá elaborar os trabalhos considerando } \\
\text { sempre a qualidade dos projetos, os requisitos de segurança } \\
\text { funcionalidade, adequação ao interesse público, economia, } \\
\text { facilidade na execução da obra, sua conservação, manutenção, } \\
\text { durabilidade, (...) }\end{array}$} \\
\hline UESPI-TN & TR item 6 & \multicolumn{4}{|c|}{$\begin{array}{l}\text { A Licitante vencedora deverá elaborar os trabalhos considerando } \\
\text { sempre a qualidade dos projetos, os requisitos de segurança } \\
\text { funcionalidade, adequação ao interesse público, economia, } \\
\text { facilidade na execução da obra, sua conservação, manutenção, } \\
\text { durabilidade, (...) }\end{array}$} \\
\hline UFU & PB item 2 & \multicolumn{4}{|c|}{ Facilidade na execução, conservação e operação; } \\
\hline
\end{tabular}


Quadro 09: Aspectos Técnicos - Manutenção / Modalidade Concorrência

\begin{tabular}{|c|c|c|c|c|c|}
\hline \multicolumn{6}{|c|}{ SÍNTESE ACHADOS DE PESQUISA } \\
\hline Modalidade & Concorrência & Categoria & $\begin{array}{l}\text { Aspectos } \\
\text { Técnicos }\end{array}$ & Critério & Manutenabilidade \\
\hline Entidade & $\begin{array}{l}\text { Localização } \\
\text { Instrumento } \\
\text { Licitatório } \\
\end{array}$ & \multicolumn{4}{|c|}{ Conteúdo } \\
\hline AL-CE & $\begin{array}{l}\text { TR item } \\
3.7 .4 . b\end{array}$ & \multicolumn{4}{|c|}{$\begin{array}{l}\text { Adoção de soluções que ofereçam facilidade de operação e } \\
\text { manutenção dos diversos componentes e sistemas da } \\
\text { edificação; }\end{array}$} \\
\hline ENAP & $\begin{array}{l}\text { PB item } \\
5.4 .1 .34\end{array}$ & \multicolumn{4}{|c|}{$\begin{array}{l}\text { A inclusão de elementos padronizados no projeto, além de } \\
\text { melhorar cada vez mais a qualidade da construção pela } \\
\text { repetição das operações, proporciona um suporte ideal para a } \\
\text { manutenção da edificação ou elemento urbano, } \\
\text { racionalizando estoques e facilitando o manuseio e troca de } \\
\text { componentes. }\end{array}$} \\
\hline & $\begin{array}{l}\text { PB item } \\
\text { 5.4.1.35 }\end{array}$ & \multicolumn{4}{|c|}{$\begin{array}{l}\text { Facilidade de execução, de conservação e manutenção dos } \\
\text { materiais escolhidos; }\end{array}$} \\
\hline IFTM & TR item 6 & \multicolumn{4}{|c|}{$\begin{array}{l}\text { Adotar soluções que ofereçam facilidades de operação e } \\
\text { manutenção dos diversos componentes e sistemas da } \\
\text { edificação; }\end{array}$} \\
\hline PGM-POA & TR item 6§5은 & \multicolumn{4}{|c|}{$\begin{array}{l}\text { Adotar soluções que ofereçam facilidade de operação e } \\
\text { manutenção dos diversos componentes e sistemas da } \\
\text { edificação. }\end{array}$} \\
\hline STM & PB item 6.g & \multicolumn{4}{|c|}{$\begin{array}{l}\text { Adoção de soluções que ofereçam facilidade de operação e } \\
\text { manutenção dos diversos componentes e sistemas da } \\
\text { edificação }\end{array}$} \\
\hline & $\begin{array}{l}\text { PB item } \\
10.8 . g\end{array}$ & \multicolumn{4}{|c|}{$\begin{array}{l}\text { Aspectos econômicos quanto aos custos iniciais e de } \\
\text { manutenção }\end{array}$} \\
\hline TJ-RO & ET item 1.g & \multicolumn{4}{|c|}{$\begin{array}{l}\text { Adoção de soluções que ofereçam facilidade de operação e } \\
\text { manutenção dos diversos componentes e sistemas da } \\
\text { edificação; }\end{array}$} \\
\hline & ET item 4.8 & \multicolumn{4}{|c|}{$\begin{array}{l}\text { A escolha dos materiais deverá levar em conta condições } \\
\text { ambientais, de manutenção de conservação (...) }\end{array}$} \\
\hline UESPI-CM & TR item 6 & \multicolumn{4}{|c|}{$\begin{array}{l}\text { A Licitante vencedora deverá elaborar os trabalhos } \\
\text { considerando sempre a qualidade dos projetos, os requisitos } \\
\text { de segurança funcionalidade, adequação ao interesse público, } \\
\text { economia, facilidade na execução da obra, sua conservação, } \\
\text { manutenção, durabilidade, (...) }\end{array}$} \\
\hline UESPI-TN & TR item 6 & \multicolumn{4}{|c|}{$\begin{array}{l}\text { A Licitante vencedora deverá elaborar os trabalhos } \\
\text { considerando sempre a qualidade dos projetos, os requisitos } \\
\text { de segurança funcionalidade, adequação ao interesse público, } \\
\text { economia, facilidade na execução da obra, sua conservação, } \\
\text { manutenção, durabilidade (...) }\end{array}$} \\
\hline
\end{tabular}


Quadro 10: Aspectos Técnicos - Disponibilidade Local dos Sistemas / Modalidade Concorrência

\begin{tabular}{|c|c|c|c|c|c|}
\hline \multicolumn{5}{|c|}{ SÍNTESE ACHADOS DE PESQUISA } \\
\hline Modalidade & Concorrência & Categoria & $\begin{array}{c}\text { Aspectos } \\
\text { Técnicos }\end{array}$ & Critério & $\begin{array}{c}\text { Disponibilidade } \\
\text { Local dos } \\
\text { Sistemas }\end{array}$ \\
\hline Entidade & $\begin{array}{c}\text { Localização } \\
\text { Instrumento } \\
\text { Licitatório }\end{array}$ & \multicolumn{4}{|c|}{ Conteúdo } \\
\hline ENAP & $\begin{array}{c}\text { TR item } \\
5.4 .1 .35 . b\end{array}$ & $\begin{array}{l}\text { A escolha dos materiais e técnicas construtivas deverá levar } \\
\text { em consideração: (...) b) Técnica construtiva adequada à } \\
\text { indústria, materiais e mão de obra locais; }\end{array}$ \\
\hline
\end{tabular}




\section{APÊNDICE E}

Quadro 01: Aspectos Ambientais - ACV / Modalidade Concorrência

\begin{tabular}{|c|c|c|c|c|c|}
\hline \multicolumn{6}{|c|}{ SÍNTESE ACHADOS DE PESQUISA } \\
\hline Modalidade & Concorrência & Categoria & $\begin{array}{c}\text { Aspectos } \\
\text { Ambientais }\end{array}$ & Critério & ACV \\
\hline Entidade & $\begin{array}{l}\text { Localização } \\
\text { Instrumento } \\
\text { Licitatório } \\
\end{array}$ & \multicolumn{4}{|c|}{ Conteúdo } \\
\hline $\mathrm{AL}-\mathrm{CE}$ & TR item 3.7.4 & \multicolumn{4}{|c|}{$\begin{array}{l}\text { Adoção de soluções de projeto e construtivas que visem ao } \\
\text { desenvolvimento sustentável ao longo de todo ciclo de vida da } \\
\text { construção; }\end{array}$} \\
\hline STM & PB item 6.b & \multicolumn{4}{|c|}{$\begin{array}{l}\text { Adoção de soluções projetuais e construtivas que visem ao } \\
\text { desenvolvimento sustentável ao longo de todo ciclo de vida da } \\
\text { construção; }\end{array}$} \\
\hline TR-RO & ET item 1.b & \multicolumn{4}{|c|}{$\begin{array}{l}\text { Adoção de soluções projetuais e construtivas que visem ao } \\
\text { desenvolvimento sustentável ao longo de todo ciclo de vida da } \\
\text { construção; }\end{array}$} \\
\hline
\end{tabular}

Quadro 02: Aspectos Ambientais - Utilização de Materiais e componentes reciclados / Modalidade Concorrência

\begin{tabular}{|c|c|c|c|c|c|}
\hline \multicolumn{6}{|c|}{ SÍNTESE ACHADOS DE PESQUISA } \\
\hline Modalidade & Concorrência & Categoria & $\begin{array}{c}\text { Aspectos } \\
\text { Ambientais }\end{array}$ & Critério & $\begin{array}{c}\text { Utilização de Mat. } \\
\text { / Comp. } \\
\text { Reciclados }\end{array}$ \\
\hline Entidade & \begin{tabular}{|c|} 
Localização \\
Instrumento \\
Licitatório \\
\end{tabular} & \multicolumn{4}{|c|}{ Conteúdo } \\
\hline STM & $\begin{array}{l}\text { PB item } \\
\text { 7.1.d }\end{array}$ & \multicolumn{4}{|c|}{$\begin{array}{l}\text { Materiais e Recursos - Encoraja o uso de materiais de baixo } \\
\text { impacto ambiental (reciclados, regionais, recicláveis, de reuso } \\
\text { etc.) e reduz a geração de resíduos, além de promover o } \\
\text { descarte consciente, desviando o volume de resíduos gerados } \\
\text { dos aterros sanitários. }\end{array}$} \\
\hline
\end{tabular}


Quadro 03: Aspectos Ambientais - Utilização de Materiais e componentes recicláveis / Modalidade Concorrência

\begin{tabular}{|c|c|c|c|c|c|}
\hline \multicolumn{6}{|c|}{ SÍNTESE ACHADOS DE PESQUISA } \\
\hline Modalidade & Concorrência & Categoria & $\begin{array}{c}\text { Aspectos } \\
\text { Ambientais }\end{array}$ & Critério & $\begin{array}{l}\text { Utilização de Mat. / } \\
\text { Comp. Recicláveis }\end{array}$ \\
\hline Entidade & $\begin{array}{l}\text { Localização } \\
\text { Instrumento } \\
\text { Licitatório }\end{array}$ & \multicolumn{4}{|c|}{ Conteúdo } \\
\hline ENAP & PB item 7.3 & \multicolumn{4}{|c|}{$\begin{array}{l}\text { Deverão ser preservados os critérios de sustentabilidade, ou } \\
\text { seja, a utilização dos recursos disponíveis com economia, o } \\
\text { reuso, e a reciclagem dos materiais sempre que necessário e } \\
\text { possível }\end{array}$} \\
\hline PGM-POA & TR item 6.1 .6 & \multicolumn{4}{|c|}{$\begin{array}{l}\text { Deverá definir materiais e métodos construtivos adequados aos } \\
\text { objetivos do empreendimento e às condições do local de } \\
\text { implantação, (...) redução do desperdício de materiais e a } \\
\text { reciclagem de resíduos sólidos. }\end{array}$} \\
\hline STM & $\begin{array}{l}\text { PB item } \\
\text { 7.1.d }\end{array}$ & \multicolumn{4}{|c|}{$\begin{array}{l}\text { Materiais e Recursos - Encoraja o uso de materiais de baixo } \\
\text { impacto ambiental (reciclados, regionais, recicláveis, de reuso } \\
\text { etc.) e reduz a geração de resíduos, além de promover o } \\
\text { descarte consciente, desviando o volume de resíduos gerados } \\
\text { dos aterros sanitários. }\end{array}$} \\
\hline
\end{tabular}

Quadro 04: Aspectos Ambientais - Utilização de Materiais e componentes Reutilizáveis / Modalidade Concorrência

\begin{tabular}{|c|c|c|c|c|c|}
\hline \multicolumn{6}{|c|}{ SÍNTESE ACHADOS DE PESQUISA } \\
\hline Modalidade & Concorrência & Categoria & $\begin{array}{l}\text { Aspectos } \\
\text { Ambientais }\end{array}$ & Critério & $\begin{array}{l}\text { Utilização de Mat. / } \\
\text { Comp. Reutilizáveis }\end{array}$ \\
\hline Entidade & $\begin{array}{c}\text { Localização } \\
\text { Instrumento } \\
\text { Licitatório }\end{array}$ & \multicolumn{4}{|c|}{ Conteúdo } \\
\hline ENAP & PB item 7.3 & \multicolumn{4}{|c|}{$\begin{array}{l}\text { Deverão ser preservados os critérios de sustentabilidade, ou } \\
\text { seja, a utilização dos recursos disponíveis com economia, o } \\
\text { reuso, e a reciclagem dos materiais sempre que necessário e } \\
\text { possível }\end{array}$} \\
\hline STM & $\begin{array}{l}\text { PB item } \\
\text { 7.1.d }\end{array}$ & \multicolumn{4}{|c|}{$\begin{array}{l}\text { Materiais e Recursos - Encoraja o uso de materiais de baixo } \\
\text { impacto ambiental (reciclados, regionais, recicláveis, de reuso } \\
\text { etc.) e reduz a geração de resíduos, além de promover o } \\
\text { descarte consciente, desviando o volume de resíduos gerados } \\
\text { dos aterros sanitários. }\end{array}$} \\
\hline UFU & PB item 2 & \multicolumn{4}{|c|}{$\begin{array}{l}\text { Prever a reutilização de recursos naturais disponíveis na área da } \\
\text { obra; }\end{array}$} \\
\hline
\end{tabular}


Quadro 05: Aspectos Ambientais - Certificação de Origem / Modalidade Concorrência

\begin{tabular}{|c|c|c|c|c|c|}
\hline \multicolumn{6}{|c|}{ SÍNTESE ACHADOS DE PESQUISA } \\
\hline Modalidade & $\begin{array}{l}\text { Concurso de } \\
\text { Projeto }\end{array}$ & Categoria & $\begin{array}{l}\text { Aspectos } \\
\text { Ambientais }\end{array}$ & Critério & $\begin{array}{l}\text { Certificação Origem } \\
\text { Mat. / Comp. }\end{array}$ \\
\hline Entidade & $\begin{array}{l}\text { Localização } \\
\text { Instrumento } \\
\text { Licitatório } \\
\end{array}$ & \multicolumn{4}{|c|}{ Conteúdo } \\
\hline IFMA & $\begin{array}{l}\text { PB item } \\
6.2 .9\end{array}$ & \multicolumn{4}{|c|}{$\begin{array}{l}\text { Todos os projetos serão elaborados levando em consideração o } \\
\text { uso de materiais equipamentos e sistemas construtivos } \\
\text { sustentáveis e/ou com certificação ambiental. A utilização de } \\
\text { sistemas de reuso de água, sistemas alternativos de captação e } \\
\text { armazenamento de energia e materiais de fácil manutenção, } \\
\text { será obrigatória sempre que possível. }\end{array}$} \\
\hline PGM-POA & TR 6.1.6 & \multicolumn{4}{|c|}{$\begin{array}{l}\text { Deverá definir materiais e métodos construtivos adequados aos } \\
\text { objetivos do empreendimento e às condições do local de } \\
\text { implantação, adotando estratégias como o uso de materiais com } \\
\text { certificação ambiental, (...) }\end{array}$} \\
\hline
\end{tabular}

Quadro 06: Aspectos Ambientais - Gestão de Resíduos / Modalidade Concorrência

\begin{tabular}{|c|c|c|c|c|c|}
\hline \multicolumn{6}{|c|}{ SÍNTESE ACHADOS DE PESQUISA } \\
\hline Modalidade & Concorrência & Categoria & $\begin{array}{c}\text { Aspectos } \\
\text { Ambientais }\end{array}$ & Critério & $\begin{array}{l}\text { Gestão de } \\
\text { Resíduos }\end{array}$ \\
\hline Entidade & $\begin{array}{l}\text { Localização } \\
\text { Instrumento } \\
\text { Licitatório } \\
\end{array}$ & \multicolumn{4}{|c|}{ Conteúdo } \\
\hline ENAP & PB item 7.3 & \multicolumn{4}{|c|}{$\begin{array}{l}\text { Deverão ser preservados os critérios de sustentabilidade, ou } \\
\text { seja, a utilização dos recursos disponíveis com economia, o } \\
\text { reuso, e a reciclagem dos materiais sempre que necessário e } \\
\text { possível, com o mínimo de comprometimento da infraestrutura } \\
\text { presente e futura, e gerando menor impacto no meio ambiente } \\
\text { e alcançando o máximo possível de autonomia. }\end{array}$} \\
\hline PGM-POA & TR item 6.1.6 & \multicolumn{4}{|c|}{$\begin{array}{l}\text { Deverá definir materiais e métodos construtivos adequados aos } \\
\text { objetivos do empreendimento e às condições do local de } \\
\text { implantação, adotando estratégias como o uso de materiais com } \\
\text { certificação ambiental, equipamentos com alta eficiência } \\
\text { energética, uso de descargas e outros dispositivos de baixo } \\
\text { consumo de água, redução do desperdício de materiais e a } \\
\text { reciclagem de resíduos sólidos. }\end{array}$} \\
\hline STM & $\begin{array}{l}\text { PB item } \\
\text { 7.1.d }\end{array}$ & \multicolumn{4}{|c|}{$\begin{array}{l}\text { Materiais e Recursos - Encoraja o uso de materiais de baixo } \\
\text { impacto ambiental (reciclados, regionais, recicláveis, de reuso } \\
\text { etc.) e reduz a geração de resíduos, além de promover o } \\
\text { descarte consciente, desviando o volume de resíduos gerados } \\
\text { dos aterros sanitários. }\end{array}$} \\
\hline
\end{tabular}




\section{APÊNDICE F}

Quadro 01: Aspectos Socioeconômicos - Custo de Construção (economicidade) /

Modalidade Concorrência

\begin{tabular}{|c|c|c|c|c|c|}
\hline \multicolumn{6}{|c|}{ SÍNTESE ACHADOS DE PESQUISA } \\
\hline Modalidade & Concorrência & Categoria & $\begin{array}{c}\text { Aspectos } \\
\text { Socioeconômicos }\end{array}$ & Critério & $\begin{array}{l}\text { Custo Construção } \\
\text { (economicidade) }\end{array}$ \\
\hline Entidade & $\begin{array}{l}\text { Localização } \\
\text { Instrumento } \\
\text { Licitatório } \\
\end{array}$ & \multicolumn{4}{|c|}{ Conteúdo } \\
\hline & \begin{tabular}{|l|} 
TR item \\
3.7.4.j \\
\end{tabular} & \multicolumn{4}{|c|}{$\begin{array}{l}\text { uso de técnica construtiva geral que vise à economicidade e à } \\
\text { exequibilidade (...) }\end{array}$} \\
\hline AL-CE & TR item 8.4.1 & \multicolumn{4}{|c|}{$\begin{array}{l}\text { A Revisão do Estudo Preliminar de Arquitetura deverá verificar a } \\
\text { adequação do projeto com o intuito de se estabelecer um } \\
\text { controle de ordem físico-econômica, impedindo a adoção de } \\
\text { partidos arquitetônicos e/ou uso de materiais que impliquem em } \\
\text { obras de custos demasiadamente elevados, bem como verificar o } \\
\text { atendimento às demandas da Contratante. }\end{array}$} \\
\hline ENAP & PB item 3.6 & \multicolumn{4}{|c|}{$\begin{array}{l}\text { A escolha dos materiais e técnicas construtivas deverá levar em } \\
\text { consideração: (...) Disponibilidade financeira; }\end{array}$} \\
\hline IFTM & TR item 7 & \multicolumn{4}{|c|}{$\begin{array}{l}\text { Os projetos serão concebidos segundo critérios que privilegiem o } \\
\text { conforto, a modernidade, a segurança, o aproveitamento de } \\
\text { recursos naturais, ofereça menores custos de execução, } \\
\text { funcionamento e manutenção e guardem perfeita consonância } \\
\text { com o que estabelecem as Normas Técnicas Brasileiras (...) }\end{array}$} \\
\hline \multirow[t]{2}{*}{ PGM-POA } & TR item 6.1 .8 & \multicolumn{4}{|c|}{$\begin{array}{l}\text { Deverá definir materiais e métodos construtivos adequados aos } \\
\text { objetivos do empreendimento e às condições do local de } \\
\text { implantação, adotando estratégias como o uso de materiais com } \\
\text { certificação ambiental, equipamentos com alta eficiência } \\
\text { energética, uso de descargas e outros dispositivos de baixo } \\
\text { consumo de água, redução do desperdício de materiais e a } \\
\text { reciclagem de resíduos sólidos. }\end{array}$} \\
\hline & $\begin{array}{l}\text { TR item } \\
6.1 .10\end{array}$ & \multicolumn{4}{|c|}{$\begin{array}{l}\text { Adotar soluções técnicas que considerem as disponibilidades } \\
\text { econômicas e financeiras para a implantação do } \\
\text { empreendimento. }\end{array}$} \\
\hline STM & Edita & \multicolumn{4}{|c|}{ Aspectos econômicos quanto aos custos iniciais e de manutenção. } \\
\hline TJ-RO & ET item 1.j & \multicolumn{4}{|c|}{$\begin{array}{l}\text { Adoção de soluções técnicas que considerem as disponibilidades } \\
\text { econômicas e financeiras para a implantação do edifício; }\end{array}$} \\
\hline UESPI-CM & TR item 4 & \multicolumn{4}{|c|}{$\begin{array}{l}\text { Os empreendimentos deverão ser planejados e concebidos de } \\
\text { forma a utilizar as novas tecnologias de materiais existentes no } \\
\text { mercado, com a finalidade aperfeiçoar o tempo de construção, } \\
\text { atentando para a funcionalidade, a economia, a eficiência } \\
\text { energética e consciência ambiental (...) }\end{array}$} \\
\hline UESPI-TN & TR item 4 & \multicolumn{4}{|c|}{$\begin{array}{l}\text { Os empreendimentos deverão ser planejados e concebidos de } \\
\text { forma a utilizar as novas tecnologias de materiais existentes no } \\
\text { mercado, com a finalidade aperfeiçoar o tempo de construção, } \\
\text { atentando para a funcionalidade, a economia, a eficiência } \\
\text { energética e consciência ambiental (...) }\end{array}$} \\
\hline UFU & PB item 2 & \multicolumn{4}{|c|}{$\begin{array}{l}\text { Favorecer a economia na execução, conservação e operação, sem } \\
\text { prejuízo da durabilidade da obra; }\end{array}$} \\
\hline
\end{tabular}


Quadro 01: Aspectos Socioeconômicos - Custo de Ciclo de Vida / Modalidade Concorrência

\begin{tabular}{|c|c|c|c|c|c|}
\hline \multicolumn{6}{|c|}{ SÍNTESE ACHADOS DE PESQUISA } \\
\hline Modalidade & Concorrência & Categoria & $\begin{array}{c}\text { Aspectos } \\
\text { Socioeconômicos }\end{array}$ & Critério & $\begin{array}{l}\text { Custo } \\
\text { de } \\
\text { Ciclo } \\
\text { de } \\
\text { Vida }\end{array}$ \\
\hline Entidade & $\begin{array}{l}\text { Localização - } \\
\text { Instrum. } \\
\text { Licitatório } \\
\end{array}$ & \multicolumn{4}{|c|}{ Conteúdo } \\
\hline$A L-C E$ & TR item 3.7.4.h & \multicolumn{4}{|c|}{$\begin{array}{l}\text { Adoção de soluções que minimizem os custos de } \\
\text { manutenção da edificação; }\end{array}$} \\
\hline ENAP & PB item 3.6 & \multicolumn{4}{|c|}{$\begin{array}{l}\text { A almejada reforma do campus vem atender às } \\
\text { necessidades físico-espaciais da Enap ao garantir para a } \\
\text { sua Sede uma localização privilegiada com concentração } \\
\text { dos serviços institucionais, educacionais e esportivos, } \\
\text { podendo a vir proporcionar um local com instalações } \\
\text { modernas de menor custo operacional e de manutenção. }\end{array}$} \\
\hline IFTM & TR item 7 & \multicolumn{4}{|c|}{$\begin{array}{l}\text { A contratada deverá apresentar uma proposta de } \\
\text { concepção em linhas gerais, oferecendo, para discussão, } \\
\text { alternativas a respeito dos métodos e técnicas a serem } \\
\text { utilizados na construção, bem como o prazo de execução } \\
\text { do empreendimento, com vistas à escolha da solução } \\
\text { mais viável sob os aspectos técnico e econômico }\end{array}$} \\
\hline & TR item 6 & \multicolumn{4}{|c|}{$\begin{array}{l}\text { Adotar soluções técnicas que considerem as } \\
\text { disponibilidades econômicas e financeiras para a } \\
\text { implantação do empreendimento; }\end{array}$} \\
\hline STM & Edital item 37 & \multicolumn{4}{|c|}{$\begin{array}{l}\text { Todas as especialidades envolvidas, na escolha de suas } \\
\text { soluções técnicas-construtivas, deverão buscar atender } \\
\text { aos requisitos de sustentabilidade e eficiência, } \\
\text { considerando todo o ciclo de vida da edificação. }\end{array}$} \\
\hline & TR item 6.b & \multicolumn{4}{|c|}{$\begin{array}{l}\text { Adoção de soluções projetuais e construtivas que visem } \\
\text { ao desenvolvimento sustentável ao longo de todo ciclo } \\
\text { de vida da construção; }\end{array}$} \\
\hline TI & ET item 1.g & \multicolumn{4}{|c|}{$\begin{array}{l}\text { Aspectos econômicos quanto aos custos iniciais e de } \\
\text { manutenção. }\end{array}$} \\
\hline $12-40$ & ET item 4.8 & \multicolumn{4}{|c|}{$\begin{array}{l}\text { A escolha dos materiais deverá levar em conta condições } \\
\text { ambientais, de manutenção de conservação (...) }\end{array}$} \\
\hline UFU & PB item 2 & \multicolumn{4}{|c|}{$\begin{array}{l}\text { Favorecer a economia na execução, conservação e } \\
\text { operação, sem prejuízo da durabilidade da obra; }\end{array}$} \\
\hline
\end{tabular}


Quadro 03: Aspectos Socioeconômicos - Utilização de mão de obra local / Modalidade Concorrência

\begin{tabular}{|c|c|c|c|c|c|}
\hline \multicolumn{6}{|c|}{ SÍNTESE ACHADOS DE PESQUISA } \\
\hline Modalidade & Concorrência & Categoria & $\begin{array}{c}\text { Aspectos } \\
\text { Socioeconômicos }\end{array}$ & Critério & $\begin{array}{l}\text { Utilização } \\
\text { de mão } \\
\text { de obra } \\
\text { local }\end{array}$ \\
\hline Entidade & $\begin{array}{l}\text { Localização - } \\
\text { Instrum. } \\
\text { Licitatório }\end{array}$ & \multicolumn{4}{|c|}{ Conteúdo } \\
\hline $\mathrm{AL}-\mathrm{CE}$ & TR item 8.3.a & \multicolumn{4}{|c|}{$\begin{array}{l}\text { Técnicas construtivas adequadas à indústria, materiais e } \\
\text { mão de obra locais; }\end{array}$} \\
\hline ENAP & PB item 5.4.1.35.b & \multicolumn{4}{|c|}{$\begin{array}{l}\text { Técnica construtiva adequada à indústria, materiais e mão } \\
\text { de obra locais; }\end{array}$} \\
\hline \multirow{2}{*}{ STM } & PB item 10.a & \multicolumn{4}{|c|}{$\begin{array}{l}\text { Técnicas construtivas adequadas à indústria, materiais e } \\
\text { mão de obra locais; }\end{array}$} \\
\hline & PB item 10.e & \multicolumn{4}{|c|}{$\begin{array}{l}\text { As especificações de serviços deverão considerar (...) } \\
\text { Disponibilidade de mão de obra. }\end{array}$} \\
\hline TJ-RO & ET item 4.8 & \multicolumn{4}{|c|}{$\begin{array}{l}\text { Técnicas construtivas adequadas à indústria, materiais e } \\
\text { mão de obra locais; }\end{array}$} \\
\hline UFU & PB item 2 & \multicolumn{4}{|c|}{$\begin{array}{l}\text { Emprego de mão-de-obra, materiais, tecnologia e matérias- } \\
\text { primas existentes na região, ressalvados os casos em que } \\
\text { seja comprovada a impossibilidade de abastecimento no } \\
\text { mercado local. }\end{array}$} \\
\hline
\end{tabular}




\section{APÊNDICE G}

Quadro 01: Aspectos Técnicos - Produtividade / Modalidade Tomada de Preços

\begin{tabular}{|c|c|c|c|c|c|}
\hline \multicolumn{6}{|c|}{ SÍNTESE ACHADOS DE PESQUISA } \\
\hline Modalidade & $\begin{array}{l}\text { Tomada de } \\
\text { Preços }\end{array}$ & Categoria & $\begin{array}{l}\text { Aspectos } \\
\text { Técnicos }\end{array}$ & Critério & Produtividade \\
\hline Entidade & $\begin{array}{l}\text { Localização } \\
\text { Instrumento } \\
\text { Licitatório } \\
\end{array}$ & \multicolumn{4}{|c|}{ Conteúdo } \\
\hline CREA-PR & $\begin{array}{l}\text { PB item } \\
\text { II.2.b }\end{array}$ & \multicolumn{4}{|c|}{$\begin{array}{l}\text { Adoção de soluções construtivas racionais elegendo, na medida } \\
\text { do possível, sistemas de modulação e padronização compatíveis } \\
\text { com as características do empreendimento; }\end{array}$} \\
\hline JF-GO & $\begin{array}{c}\text { Anexo I item } \\
4.1 .3\end{array}$ & \multicolumn{4}{|c|}{$\begin{array}{l}\text { considerar os requisitos de (...) facilidade e economia na } \\
\text { execução, conservação e operação, sem prejuízo da durabilidade } \\
\text { da obra ou do serviço; adoção das normas técnicas de saúde e } \\
\text { de segurança do trabalho adequadas; }\end{array}$} \\
\hline JF-MG & $\begin{array}{c}\text { Anexo I item } \\
\text { 4.2.c }\end{array}$ & \multicolumn{4}{|c|}{$\begin{array}{l}\text { considerar os requisitos de (...) facilidade e economia na } \\
\text { execução, conservação e operação, sem prejuízo da durabilidade } \\
\text { da obra ou do serviço; adoção das normas técnicas de saúde e } \\
\text { de segurança do trabalho adequadas; }\end{array}$} \\
\hline PISAC & $\begin{array}{l}\text { Edital Anexo } \\
\text { I item } 4.1 .4\end{array}$ & \multicolumn{4}{|c|}{$\begin{array}{l}\text { Definição de conceitos, princípios e as diretrizes norteadoras } \\
\text { para atendimento a cada uma das dimensões do projeto, tais } \\
\text { como: (...) construtibilidade. }\end{array}$} \\
\hline TRE-AL & PB item 6.e & \multicolumn{4}{|c|}{$\begin{array}{l}\text { Adoção soluções construtivas racionais elegendo, sempre que } \\
\text { possível, sistemas de modulação e padronização compatíveis } \\
\text { com as características da edificação; }\end{array}$} \\
\hline TRE-PB & PB item V & \multicolumn{4}{|c|}{$\begin{array}{l}\text { adotar solução construtiva racional, elegendo sempre que } \\
\text { possível, sistemas de modulação e padronização compatíveis } \\
\text { com as características do empreendimento; }\end{array}$} \\
\hline UFTPR & $\begin{array}{l}\text { PB item } \\
4.5 .4 . b\end{array}$ & \multicolumn{4}{|c|}{$\begin{array}{l}\text { A concepção deverá considerar os seguintes itens: (...)facilidade } \\
\text { de fabricação e montagem. }\end{array}$} \\
\hline
\end{tabular}


Quadro 02: Aspectos Técnicos - Qualidade / Modalidade Tomada de Preços

\begin{tabular}{|c|c|c|c|c|c|}
\hline \multicolumn{6}{|c|}{ SÍNTESE ACHADOS DE PESQUISA } \\
\hline Modalidade & $\begin{array}{l}\text { Tomada de } \\
\text { Preço }\end{array}$ & Categoria & $\begin{array}{l}\text { Aspectos } \\
\text { Técnicos }\end{array}$ & Critério & Qualidade \\
\hline Entidade & $\begin{array}{l}\text { Localização } \\
\text { Instrumento } \\
\text { Licitatório }\end{array}$ & \multicolumn{4}{|c|}{ Conteúdo } \\
\hline CREA-PR & $\begin{array}{l}\text { PB item } \\
\text { II.13.i.i }\end{array}$ & \multicolumn{4}{|c|}{$\begin{array}{l}\text { Quanto aos materiais, que serão escolhidos se levando em } \\
\text { conta as condições ambientais, de manutenção e de } \\
\text { conservação, deverão ser citadas as normas de referência, } \\
\text { seu padrão de qualidade e eventuais testes para recebimento } \\
\text { e aceitação (...) }\end{array}$} \\
\hline TRE-AL & $\begin{array}{l}\text { PB item } \\
10.8 .3 . c\end{array}$ & \multicolumn{4}{|c|}{$\begin{array}{l}\text { As especificações de serviços deverão considerar: (...) } \\
\text { Acabamento superficial; }\end{array}$} \\
\hline USP & DT item 5.2 & \multicolumn{4}{|c|}{$\begin{array}{l}\text { Todos os materiais especificados deverão ser de } 1 \text { a. } \\
\text { qualidade, sendo considerado de 1a. qualidade o sentido } \\
\text { comercialmente adotado como de gradação de qualidade } \\
\text { superior e onde aplicável o selo de certificacão do INMETRO. }\end{array}$} \\
\hline
\end{tabular}

Quadro 03: Aspectos Técnicos - Flexibilidade / Modalidade Tomada de Preços

\begin{tabular}{|c|c|c|c|c|c|}
\hline \multicolumn{6}{|c|}{ SÍNTESE ACHADOS DE PESQUISA } \\
\hline Modalidade & $\begin{array}{l}\text { Tomada de } \\
\text { Preço }\end{array}$ & Categoria & $\begin{array}{l}\text { Aspectos } \\
\text { Técnicos }\end{array}$ & Critério & Flexibilidade \\
\hline Entidade & $\begin{array}{l}\text { Localização } \\
\text { Instrumento } \\
\text { Licitatório }\end{array}$ & \multicolumn{4}{|c|}{ Conteúdo } \\
\hline JF-GO & $\begin{array}{l}\text { Anexo I item } \\
\text { 4.2.6.1 }\end{array}$ & \multicolumn{4}{|c|}{$\begin{array}{l}\text { Adotar soluções construtivas que garantam maior } \\
\text { flexibilidade na construção, de maneira a permitir fácil } \\
\text { adaptação às mudanças de uso do ambiente ou de usuário, } \\
\text { no decorrer do tempo, e evitar reformas que podem causar } \\
\text { grande impacto ambiental, pela produção do entulho; }\end{array}$} \\
\hline JF-MG & $\begin{array}{l}\text { Anexo I item } \\
\text { 4.2.5.a }\end{array}$ & \multicolumn{4}{|c|}{$\begin{array}{l}\text { Adotar soluções construtivas que garantam maior } \\
\text { flexibilidade na construção, de maneira a permitir fácil } \\
\text { adaptação às mudanças de uso do ambiente ou de usuário, } \\
\text { no decorrer do tempo, e evitar reformas que possam causar } \\
\text { grande impacto ambiental, pela produção do entulho; }\end{array}$} \\
\hline PISAC & $\begin{array}{l}\text { Edital Anexo I } \\
\text { item 4.1.4 }\end{array}$ & \multicolumn{4}{|c|}{$\begin{array}{l}\text { Definição de conceitos, princípios e as diretrizes norteadoras } \\
\text { para atendimento a cada uma das dimensões do projeto, tais } \\
\text { como: (...) flexibilidade (...) }\end{array}$} \\
\hline TRE-AL & PB item 6.f & \multicolumn{4}{|c|}{$\begin{array}{l}\text { Adoção de soluções flexíveis e versáteis nas áreas destinadas } \\
\text { às atividades comuns e públicas; }\end{array}$} \\
\hline
\end{tabular}


Quadro 04: Aspectos Técnicos - Expansibilidade ou Adaptabilidade / Modalidade Tomada de Preços

\begin{tabular}{|c|c|c|c|c|c|}
\hline \multicolumn{6}{|c|}{ SÍNTESE ACHADOS DE PESQUISA } \\
\hline Modalidade & $\begin{array}{l}\text { Tomada de } \\
\text { Preços }\end{array}$ & Categoria & $\begin{array}{l}\text { Aspectos } \\
\text { Técnicos }\end{array}$ & Critério & $\begin{array}{l}\text { Expansibilidade / } \\
\text { Adaptabilidade }\end{array}$ \\
\hline Entidade & $\begin{array}{l}\text { Localização } \\
\text { Instrumento } \\
\text { Licitatório } \\
\end{array}$ & \multicolumn{4}{|c|}{ Conteúdo } \\
\hline JF-GO & $\begin{array}{c}\text { Anexo I item } \\
4.1 .4\end{array}$ & \multicolumn{4}{|c|}{$\begin{array}{l}\text { conseguir, da melhor maneira possível, suprir as } \\
\text { necessidades físicas atuais e futuras da instituição (prever } \\
\text { possibilidades de ampliação); }\end{array}$} \\
\hline JF-MG & $\begin{array}{c}\text { Anexo I item } \\
\text { 4.1.d }\end{array}$ & \multicolumn{4}{|c|}{$\begin{array}{l}\text { conseguir, da melhor maneira possível, suprir as } \\
\text { necessidades físicas atuais e futuras da instituição, com } \\
\text { previsão de futuras ampliações; }\end{array}$} \\
\hline USP & Anexo I 5.2 & \multicolumn{4}{|c|}{$\begin{array}{l}\text { Por se tratarem de edificações em uso, o projeto deverá } \\
\text { prever as intervenções em etapas, de modo a permitir a } \\
\text { continuidade das atividades da Superintendência } \\
\text { concomitantemente às obras. }\end{array}$} \\
\hline
\end{tabular}

Quadro 05: Aspectos Técnicos - Interface entre os sistemas / Modalidade Tomada de Preços

\begin{tabular}{|c|c|c|c|c|c|}
\hline \multicolumn{6}{|c|}{ SÍNTESE ACHADOS DE PESQUISA } \\
\hline Modalidade & $\begin{array}{l}\text { Tomada de } \\
\text { Preço }\end{array}$ & Categoria & $\begin{array}{l}\text { Aspectos } \\
\text { Técnicos }\end{array}$ & Critério & $\begin{array}{l}\text { Interface entre } \\
\text { os sistemas }\end{array}$ \\
\hline Entidade & $\begin{array}{l}\text { Localização } \\
\text { Instrumento } \\
\text { Licitatório }\end{array}$ & \multicolumn{4}{|c|}{ Conteúdo } \\
\hline CREA-PR & PB item II.2 & \multicolumn{4}{|c|}{$\begin{array}{l}\text { Todos os estudos e projetos deverão ser desenvolvidos de forma } \\
\text { harmônica, consistente e coordenada, observando a não } \\
\text { interferência entre os elementos dos diversos sistemas da } \\
\text { edificação (...) }\end{array}$} \\
\hline JF-GO & $\begin{array}{c}\text { Anexo I } \\
\text { item } 4\end{array}$ & \multicolumn{4}{|c|}{$\begin{array}{l}\text { Todos os estudos e projetos deverão ser desenvolvidos de forma } \\
\text { harmônica, consistente e coordenada, observando a não } \\
\text { interferência entre os elementos dos diversos sistemas da } \\
\text { edificação (...) }\end{array}$} \\
\hline JF-MG & $\begin{array}{c}\text { Anexo I } \\
\text { item } 4\end{array}$ & \multicolumn{4}{|c|}{$\begin{array}{l}\text { Todos os estudos e projetos deverão ser desenvolvidos de forma } \\
\text { harmônica, consistente e coordenada, observando a não } \\
\text { interferência entre os elementos dos diversos sistemas da } \\
\text { edificação (...) }\end{array}$} \\
\hline PISAC & TR item 4.3 & \multicolumn{4}{|c|}{$\begin{array}{l}\text { A partir da negociação de soluções de interferências entre } \\
\text { sistemas, o projeto resultante deve ter todas as suas interfaces } \\
\text { resolvidas. }\end{array}$} \\
\hline TRE-AL & PB item 6 & \multicolumn{4}{|c|}{$\begin{array}{l}\text { Todos os estudos e projetos deverão ser desenvolvidos de forma } \\
\text { harmônica e consistente, observando a não interferência entre } \\
\text { os elementos dos diversos sistemas da edificação (...) }\end{array}$} \\
\hline UTFPR & $\begin{array}{l}\mathrm{PB} \text { item } \\
\text { 4.5.4.b }\end{array}$ & \multicolumn{4}{|c|}{$\begin{array}{l}\text { (...) análise da interface entre a estrutura e projetos hidráulicos, } \\
\text { elétricos e de ar condicionado; }\end{array}$} \\
\hline
\end{tabular}


Quadro 06: Aspectos Técnicos - Operação Eficiente / Modalidade Tomada de Preços

\begin{tabular}{|c|c|c|c|c|c|}
\hline \multicolumn{6}{|c|}{ SÍNTESE ACHADOS DE PESQUISA } \\
\hline Modalidade & $\begin{array}{l}\text { Tomada de } \\
\text { Preços }\end{array}$ & Categoria & $\begin{array}{l}\text { Aspectos } \\
\text { Técnicos }\end{array}$ & Critério & $\begin{array}{l}\text { Operação eficiente } \\
\text { empreendimento }\end{array}$ \\
\hline Entidade & $\begin{array}{l}\text { Localização } \\
\text { Instrumento } \\
\text { Licitatório }\end{array}$ & \multicolumn{4}{|c|}{ Conteúdo } \\
\hline CREA-PR & PB item II.2.d & \multicolumn{4}{|c|}{$\begin{array}{l}\text { Adoção de soluções que ofereçam facilidade de operação e } \\
\text { manutenção dos diversos componentes e sistemas da } \\
\text { edificação. }\end{array}$} \\
\hline JF-GO & $\begin{array}{l}\text { Anexo I item } \\
\quad 4.1 .7\end{array}$ & \multicolumn{4}{|c|}{$\begin{array}{l}\text { adotar soluções que ofereçam facilidades de operação e } \\
\text { manutenção dos diversos componentes e sistemas da } \\
\text { edificação; }\end{array}$} \\
\hline JF-MG & $\begin{array}{l}\text { Anexo I item } \\
\text { 4.1.g }\end{array}$ & \multicolumn{4}{|c|}{$\begin{array}{l}\text { Adotar soluções que ofereçam facilidades de operação e } \\
\text { manutenção dos diversos componentes e sistemas da } \\
\text { edificação; }\end{array}$} \\
\hline PISAC & $\begin{array}{l}\text { Anexo I item } \\
\quad 3.7\end{array}$ & \multicolumn{4}{|c|}{$\begin{array}{l}\text { Priorizar a especificação de materiais que tenham, } \\
\text { comprovadamente, baixo impacto socioambiental em sua } \\
\text { fabricação, bem como em seu transporte e manuseio. }\end{array}$} \\
\hline TRE-AL & PB item 6.g & \multicolumn{4}{|c|}{$\begin{array}{l}\text { Adoção de soluções que ofereçam facilidade de operação, } \\
\text { manutenção e reposição dos diversos componentes e sistemas } \\
\text { da edificação, desde que devidamente comprovada a } \\
\text { existência de assistência efetiva; }\end{array}$} \\
\hline TRE-PB & ET item 1.g & \multicolumn{4}{|c|}{$\begin{array}{l}\text { Adotar soluções que ofereçam facilidades de operação e } \\
\text { manutenção dos diversos componentes e sistemas da } \\
\text { edificação; }\end{array}$} \\
\hline TRE-SP & TR item 4.1.8 & \multicolumn{4}{|c|}{$\begin{array}{l}\text { O projeto deverá obedecer a critérios de conforto, } \\
\text { modernidade, ventilação e claridade dos espaços físicos, } \\
\text { qualidade do ar interno, desempenho, sustentabilidade, } \\
\text { segurança ao fogo, segurança patrimonial, segurança no uso e } \\
\text { operação, acessibilidade, ergonomia e manutenibilidade; }\end{array}$} \\
\hline USP & DT item 5.2 & \multicolumn{4}{|c|}{$\begin{array}{l}\text { Soluções que ofereçam facilidades de operação e manutenção } \\
\text { dos diversos componentes e sistemas da edificação; }\end{array}$} \\
\hline
\end{tabular}


Quadro 07: Aspectos Técnicos - Manutenção / Modalidade Tomada de Preços

\begin{tabular}{|c|c|c|c|c|c|}
\hline \multicolumn{6}{|c|}{ SÍNTESE ACHADOS DE PESQUI } \\
\hline Modalidade & $\begin{array}{l}\text { Tomada de } \\
\text { Preço }\end{array}$ & Categoria & $\begin{array}{l}\text { Aspectos } \\
\text { Técnicos }\end{array}$ & Critério & Manutenabilidade \\
\hline Entidade & $\begin{array}{l}\text { Localização } \\
\text { Instrumento } \\
\text { Licitatório }\end{array}$ & \multicolumn{4}{|c|}{ Conteúdo } \\
\hline CREA-PR & $\begin{array}{l}\text { PB item } \\
\text { II.2.d }\end{array}$ & \multicolumn{4}{|c|}{$\begin{array}{l}\text { Adoção de soluções que minimizem os custos e ofereçam } \\
\text { facilidade de operação e manutenção dos diversos componentes } \\
\text { e sistemas da edificação; }\end{array}$} \\
\hline JF-GO & $\begin{array}{l}\text { Anexo I item } \\
\quad 4.1 .7\end{array}$ & \multicolumn{4}{|c|}{$\begin{array}{l}\text { adotar soluções que ofereçam facilidades de operação e } \\
\text { manutenção dos diversos componentes e sistemas da } \\
\text { edificação; }\end{array}$} \\
\hline JF-MG & $\begin{array}{l}\text { Anexo I item } \\
4.1 .8\end{array}$ & \multicolumn{4}{|c|}{$\begin{array}{l}\text { Adotar soluções que ofereçam facilidade de operação e } \\
\text { manutenção dos diversos componentes e sistemas da } \\
\text { edificação. }\end{array}$} \\
\hline TRE-AL & PB item 6.g & \multicolumn{4}{|c|}{$\begin{array}{l}\text { Adoção de soluções que ofereçam facilidade de operação, } \\
\text { manutenção e reposição dos diversos componentes e sistemas } \\
\text { da edificação, desde que devidamente comprovada a existência } \\
\text { de assistência efetiva; }\end{array}$} \\
\hline TRE-PB & PB item V & \multicolumn{4}{|c|}{$\begin{array}{l}\text { adotar soluções que ofereçam facilidades de operação e } \\
\text { manutenção dos diversos componentes e sistemas da } \\
\text { edificação; }\end{array}$} \\
\hline TRE-SP & $\begin{array}{c}\text { ET item } \\
4.1 .8\end{array}$ & \multicolumn{4}{|c|}{$\begin{array}{l}\text { O projeto deverá obedecer a critérios de conforto, modernidade, } \\
\text { ventilação e claridade dos espaços físicos, qualidade do ar } \\
\text { interno, desempenho, sustentabilidade, segurança ao fogo, } \\
\text { segurança patrimonial, segurança no uso e operação, } \\
\text { acessibilidade, ergonomia e manutenibilidade. }\end{array}$} \\
\hline USP & DT item 5.2 & \multicolumn{4}{|c|}{$\begin{array}{l}\text { Soluções que ofereçam facilidades de operação e manutenção } \\
\text { dos diversos componentes e sistemas da edificação; }\end{array}$} \\
\hline
\end{tabular}


Quadro 08: Aspectos Técnicos - Disponibilidade local dos Sistemas / Modalidade Tomada de Preços

\begin{tabular}{|c|c|c|c|c|c|}
\hline \multicolumn{6}{|c|}{ SÍNTESE ACHADOS DE PESQUISA } \\
\hline Modalidade & $\begin{array}{l}\text { Tomada de } \\
\text { Preços }\end{array}$ & Categoria & $\begin{array}{l}\text { Aspectos } \\
\text { Técnicos }\end{array}$ & Critério & $\begin{array}{c}\text { Disponibilidade } \\
\text { local dos Sistemas }\end{array}$ \\
\hline Entidade & $\begin{array}{c}\text { Localização } \\
\text { Instrumento } \\
\text { Licitatório }\end{array}$ & \multicolumn{4}{|c|}{ Conteúdo } \\
\hline CREA-PR & PB item II.2.d & \multicolumn{4}{|c|}{$\begin{array}{l}\text { Técnicas construtivas adequadas à indústria, materiais e mão } \\
\text { de obra locais; }\end{array}$} \\
\hline JF-GO & $\begin{array}{c}\text { Anexo I item } \\
4.1 .3\end{array}$ & \multicolumn{4}{|c|}{$\begin{array}{l}\text { considerar os requisitos de segurança, funcionalidade e } \\
\text { adequação ao interesse público, possibilidade de emprego de } \\
\text { mão de obra, materiais, tecnologia e matérias primas } \\
\text { existentes no local para execução, de modo a diminuir custos } \\
\text { de transporte; facilidade e economia na execução, conservação } \\
\text { e operação, sem prejuízo da durabilidade da obra ou do } \\
\text { serviço; adoção das normas técnicas de saúde e de segurança } \\
\text { do trabalho adequadas; }\end{array}$} \\
\hline JF-MG & $\begin{array}{c}\text { Anexo I item } \\
\text { 4.1.c }\end{array}$ & \multicolumn{4}{|c|}{$\begin{array}{l}\text { considerar os requisitos de segurança, funcionalidade e } \\
\text { adequação ao interesse público; possibilidade de emprego de } \\
\text { mão de obra, materiais, tecnologia e matérias primas } \\
\text { existentes no local para execução, de modo a diminuir custos } \\
\text { de transporte; facilidade e economia na execução, conservação } \\
\text { e operação, sem prejuízo da durabilidade da obra ou do } \\
\text { serviço; adoção das normas técnicas de saúde e de segurança } \\
\text { do trabalho adequadas; }\end{array}$} \\
\hline TRE-AL & $\begin{array}{l}\text { PB item } \\
\text { 10.8.2.a }\end{array}$ & \multicolumn{4}{|c|}{$\begin{array}{l}\text { Utilização de materiais e métodos construtivos adequados aos } \\
\text { objetivos do empreendimento e às condições do local de } \\
\text { implantação }\end{array}$} \\
\hline
\end{tabular}




\section{APÊNDICE H}

Quadro 01: Aspectos Ambientais - ACV / Modalidade Tomada de Preços

\begin{tabular}{|c|c|c|c|c|c|}
\hline \multicolumn{6}{|c|}{ SÍNTESE ACHADOS DE PESQUISA } \\
\hline Modalidade & $\begin{array}{c}\text { Tomada de } \\
\text { Preços }\end{array}$ & Categoria & $\begin{array}{c}\text { Aspectos } \\
\text { Ambientais }\end{array}$ & Critério & $\mathrm{ACV}$ \\
\hline Entidade & $\begin{array}{l}\text { Localização } \\
\text { Instrumento } \\
\text { Licitatório } \\
\end{array}$ & \multicolumn{4}{|c|}{ Conteúdo } \\
\hline CREA-PR & $\begin{array}{l}\text { PB item } \\
\text { II.2.c }\end{array}$ & \multicolumn{4}{|c|}{$\begin{array}{l}\text { Adoção de soluções de projeto e construtivas que visem ao } \\
\text { desenvolvimento sustentável ao longo de todo ciclo de vida da } \\
\text { construção; }\end{array}$} \\
\hline \multirow[b]{2}{*}{ JF-GO } & $\begin{array}{l}\text { Anexo I item } \\
4.2 .4 .2\end{array}$ & \multicolumn{4}{|c|}{$\begin{array}{l}\text { Planejamento para maior durabilidade possível nas } \\
\text { especificações visando alta performance e evitando } \\
\text { obsolescência prematura; }\end{array}$} \\
\hline & $\begin{array}{l}\text { Anexo I item } \\
4.2 .6 .2\end{array}$ & \multicolumn{4}{|c|}{$\begin{array}{l}\text { Adoção de materiais que sejam duráveis, não somente pelas } \\
\text { suas características técnicas, mas também em função do seu } \\
\text { desempenho e comportamento ao longo do tempo, o que } \\
\text { resulta em longevidade para o edifício. }\end{array}$} \\
\hline \multirow{2}{*}{ JF-MG } & $\begin{array}{l}\text { Anexo I item } \\
\text { 4.2.3.a }\end{array}$ & \multicolumn{4}{|c|}{$\begin{array}{l}\text { Maximização na especificação de materiais sustentáveis, } \\
\text { objetivando o maior volume possível de utilização de materiais } \\
\text { certificados, de manejo sustentável e recicláveis; }\end{array}$} \\
\hline & $\begin{array}{l}\text { Anexo I item } \\
\text { 4.2.3.b }\end{array}$ & \multicolumn{4}{|c|}{$\begin{array}{l}\text { Planejamento para maior durabilidade possível nas } \\
\text { especificações, visando à alta performance e evitando } \\
\text { obsolescência prematura; }\end{array}$} \\
\hline TRE-AL & PB item 6.b & \multicolumn{4}{|c|}{$\begin{array}{l}\text { Adoção de soluções projetuais e construtivas que visem ao } \\
\text { desenvolvimento sustentável ao longo de todo ciclo de vida da } \\
\text { construção; }\end{array}$} \\
\hline
\end{tabular}

Quadro 02: Aspectos Ambientais - Utilização de Materiais e Componentes Recicláveis / Modalidade Tomada de Preços

\begin{tabular}{|c|c|c|c|c|c|}
\hline \multicolumn{6}{|c|}{ SÍNTESE ACHADOS DE PESQUISA } \\
\hline Modalidade & $\begin{array}{l}\text { Tomada de } \\
\text { Preços }\end{array}$ & Categoria & $\begin{array}{c}\text { Aspectos } \\
\text { Ambientais }\end{array}$ & Critério & $\begin{array}{l}\text { Utilização de Mat. / } \\
\text { Comp. Recicláveis }\end{array}$ \\
\hline Entidade & $\begin{array}{l}\text { Localização } \\
\text { Instrumento } \\
\text { Licitatório }\end{array}$ & \multicolumn{4}{|c|}{ Conteúdo } \\
\hline JF-GO & $\begin{array}{l}\text { Anexo I item } \\
\text { 4.2.4.1 }\end{array}$ & \multicolumn{4}{|c|}{$\begin{array}{l}\text { Maximização na especificação de materiais sustentáveis } \\
\text { objetivando o maior volume possível de utilização de materiais } \\
\text { certificados, de manejo sustentável e recicláveis }\end{array}$} \\
\hline JF-MG & $\begin{array}{l}\text { Anexo I item } \\
\text { 4.2.3.a }\end{array}$ & \multicolumn{4}{|c|}{$\begin{array}{l}\text { Maximização na especificação de materiais sustentáveis, } \\
\text { objetivando o maior volume possível de utilização de materiais } \\
\text { certificados, de manejo sustentável e recicláveis; }\end{array}$} \\
\hline
\end{tabular}


Quadro 03: Aspectos Ambientais - Utilização de Materiais e Componentes Reutilizáveis / Modalidade Tomada de Preços

\begin{tabular}{|c|c|c|c|c|c|}
\hline \multicolumn{6}{|c|}{ SÍNTESE ACHADOS DE PESQUISA } \\
\hline Modalidade & $\begin{array}{l}\text { Tomada de } \\
\text { Preços }\end{array}$ & Categoria & $\begin{array}{l}\text { Aspectos } \\
\text { Ambientais }\end{array}$ & Critério & $\begin{array}{l}\text { Utilização de Mat. / } \\
\text { Comp. Reutilizáveis }\end{array}$ \\
\hline Entidade & $\begin{array}{l}\text { Localização } \\
\text { Instrumento } \\
\text { Licitatório }\end{array}$ & \multicolumn{4}{|c|}{ Conteúdo } \\
\hline USP & DT item 5.2 & \multicolumn{4}{|c|}{$\begin{array}{l}\text { Nos memoriais deve estar evidenciada a exigência da } \\
\text { construtora CONTRATADA apresentar plano de gestão de } \\
\text { tratamento dos resíduos sólidos gerados em obra, com as } \\
\text { medidas que serão tomadas para minimizar o impacto } \\
\text { ambiental de suas atividades e o detalhamento das ações para } \\
\text { a redução de desperdícios, segregação dos materiais para } \\
\text { reutilização no próprio canteiro, transporte (através de } \\
\text { caçambeiros credenciados) dos resíduos para reciclagem para } \\
\text { aterros próprios. }\end{array}$} \\
\hline
\end{tabular}

Quadro 04: Aspectos Ambientais - Certificação de Origem / Modalidade Tomada de Preços

\begin{tabular}{|c|c|c|c|c|c|}
\hline \multicolumn{6}{|c|}{ SÍNTESE ACHADOS DE PESQUISA } \\
\hline Modalidade & $\begin{array}{l}\text { Tomada de } \\
\text { Preços }\end{array}$ & Categoria & $\begin{array}{l}\text { Aspectos } \\
\text { Ambientais }\end{array}$ & Critério & $\begin{array}{c}\text { Certificação Origem } \\
\text { Mat. / Comp. }\end{array}$ \\
\hline Entidade & $\begin{array}{l}\text { Localização } \\
\text { Instrumento } \\
\text { Licitatório }\end{array}$ & \multicolumn{4}{|c|}{ onteúdo } \\
\hline CREA-PR & PB item II.2.j & \multicolumn{4}{|c|}{$\begin{array}{l}\text { Deverão ser utilizados materiais e tecnologias de baixo } \\
\text { impacto ambiental, que promovam a conservação e o uso } \\
\text { racional da água, a eficiência energética e a especificação de } \\
\text { produtos com certificação ambiental (...); }\end{array}$} \\
\hline JF-GO & $\begin{array}{l}\text { Anexo I item } \\
\text { 4.2.4.1 }\end{array}$ & \multicolumn{4}{|c|}{$\begin{array}{l}\text { Maximização na especificação de materiais sustentáveis } \\
\text { objetivando o maior volume possível de utilização de materiais } \\
\text { certificados, de manejo sustentável e recicláveis }\end{array}$} \\
\hline JF-GO & $\begin{array}{l}\text { Anexo I item } \\
\text { 4.2.3.a }\end{array}$ & \multicolumn{4}{|c|}{$\begin{array}{l}\text { Maximização na especificação de materiais sustentáveis, } \\
\text { objetivando o maior volume possível de utilização de materiais } \\
\text { certificados, de manejo sustentável e recicláveis; }\end{array}$} \\
\hline PISAC & $\begin{array}{l}\text { Anexo I item } \\
3.7\end{array}$ & \multicolumn{4}{|c|}{$\begin{array}{l}\text { Especificação de materiais: Priorizar a especificação de } \\
\text { materiais que tenham, comprovadamente, baixo impacto } \\
\text { socioambiental em sua fabricação, bem como em seu } \\
\text { transporte e manuseio. }\end{array}$} \\
\hline
\end{tabular}


Quadro 05: Aspectos Ambientais - Gestão de Resíduos / Modalidade Tomada de Preços

\begin{tabular}{|c|c|c|c|c|c|}
\hline \multicolumn{6}{|c|}{ SÍNTESE ACHADOS DE PESQUISA } \\
\hline Modalidade & $\begin{array}{l}\text { Tomada de } \\
\text { Preços }\end{array}$ & Categoria & $\begin{array}{l}\text { Aspectos } \\
\text { Ambientais }\end{array}$ & Critério & $\begin{array}{l}\text { Gestão de } \\
\text { Resíduos }\end{array}$ \\
\hline Entidade & $\begin{array}{l}\text { Localização } \\
\text { Instrumento } \\
\text { Licitatório }\end{array}$ & \multicolumn{4}{|c|}{ Conteúdo } \\
\hline JF-GO & $\begin{array}{l}\text { Anexo I item } \\
4.2 .1\end{array}$ & \multicolumn{4}{|c|}{$\begin{array}{l}\text { Todos os projetos deverão adotar medidas que sigam os } \\
\text { princípios básicos de uma construção sustentável: (...) - } \\
\text { Redução dos resíduos; (...) Reciclar, reutilizar e reduzir os } \\
\text { resíduos sólidos; }\end{array}$} \\
\hline JF-MG & $\begin{array}{l}\text { Anexo I item } \\
4.2\end{array}$ & \multicolumn{4}{|c|}{$\begin{array}{l}\text { Todos os projetos deverão adotar medidas que sigam os } \\
\text { princípios básicos de uma construção sustentável: (...) - } \\
\text { Redução dos resíduos; (...) Reciclar, reutilizar e reduzir os } \\
\text { resíduos sólidos; }\end{array}$} \\
\hline PISAC & TR item 3.6 & \multicolumn{4}{|c|}{$\begin{array}{l}\text { Gestão de Resíduos: Garantir que os impactos de resíduos } \\
\text { gerados por recursos utilizados para a construção dos objetos } \\
\text { de projeto e pela sua eventual demolição sejam atentamente } \\
\text { observadas e minoradas. }\end{array}$} \\
\hline TRE-AL & Edital 35 & \multicolumn{4}{|c|}{$\begin{array}{l}\text { Deverá ser prevista no orçamento de obra a elaboração do } \\
\text { Projeto de Canteiro visando à Prevenção da Poluição na } \\
\text { Atividade da Construção, redução de custos, além de } \\
\text { instituição de um PGRCC (Programa de Gerenciamento de } \\
\text { Resíduos da Construção Civil), assim como valores de registros, } \\
\text { consultorias e aprovações necessários na etapa da obra. }\end{array}$} \\
\hline USP & DT item 5.2 & \multicolumn{4}{|c|}{$\begin{array}{l}\text { Nos memoriais deve estar evidenciada a exigência da } \\
\text { construtora CONTRATADA apresentar plano de gestão de } \\
\text { tratamento dos resíduos sólidos gerados em obra, com as } \\
\text { medidas que serão tomadas para minimizar o impacto } \\
\text { ambiental de suas atividades e o detalhamento das ações para } \\
\text { a redução de desperdícios, segregação dos materiais para } \\
\text { reutilização no próprio canteiro, transporte (através de } \\
\text { caçambeiros credenciados) dos resíduos para reciclagem para } \\
\text { aterros próprios. }\end{array}$} \\
\hline
\end{tabular}




\section{APÊNDICE I}

Quadro 01: Aspectos Socioeconômicos - Custo de Construção (Economicidade) / Modalidade Tomada de Preços

\begin{tabular}{|c|c|c|c|c|c|}
\hline \multicolumn{6}{|c|}{ SÍNTESE ACHADOS DE PESQUISA } \\
\hline Modalidade & $\begin{array}{l}\text { Tomada de } \\
\text { Preços }\end{array}$ & Categoria & $\begin{array}{c}\text { Aspectos } \\
\text { Socioeconômicos }\end{array}$ & Critério & $\begin{array}{c}\text { Custo } \\
\text { Construção } \\
\text { (economicidade) }\end{array}$ \\
\hline Entidade & $\begin{array}{l}\text { Localização } \\
\text { Instrumento } \\
\text { Licitatório }\end{array}$ & \multicolumn{4}{|c|}{ Conteúdo } \\
\hline CM-Cotia & \begin{tabular}{|l} 
Edital / \\
Minuta item \\
5.4 .3
\end{tabular} & \multicolumn{4}{|c|}{$\begin{array}{l}\text { A CONTRATADA realizará estudo preliminar a fim de verificar as } \\
\text { soluções mais adequadas, buscando solução econômica e que } \\
\text { minimize os impactos negativos gerados pelas obras, bem } \\
\text { como a descaracterização arquitetônica das edificações } \\
\text { existentes (...) }\end{array}$} \\
\hline CREA-PR & PB item II.2.a & \multicolumn{4}{|c|}{$\begin{array}{l}\text { Adoção de soluções técnicas que considerem as } \\
\text { disponibilidades econômicas e financeiras para a implantação } \\
\text { do empreendimento; }\end{array}$} \\
\hline \multirow{3}{*}{ JF-GO } & $\begin{array}{l}\text { Anexo I item } \\
2.4\end{array}$ & \multicolumn{4}{|c|}{$\begin{array}{l}\text { A Contratada deverá verificar a possibilidade de conceber um } \\
\text { projeto (...) objetivando a redução dos custos para construção } \\
\text { do edifício dentro de um processo sustentável; item }\end{array}$} \\
\hline & $\begin{array}{l}\text { Anexo I item } \\
4.1 .3\end{array}$ & \multicolumn{4}{|c|}{$\begin{array}{l}\text { considerar os requisitos de segurança, funcionalidade e } \\
\text { adequação ao interesse público, possibilidade de emprego de } \\
\text { mão de obra, materiais, tecnologia e matérias primas } \\
\text { existentes no local para execução, de modo a diminuir custos } \\
\text { de transporte; facilidade e economia na execução, conservação } \\
\text { e operação, (...) }\end{array}$} \\
\hline & $\begin{array}{l}\text { Anexo I item } \\
4.1 .8\end{array}$ & \multicolumn{4}{|c|}{$\begin{array}{l}\text { adotar soluções técnicas que considerem as disponibilidades } \\
\text { econômicas e financeiras para a implantação do } \\
\text { empreendimento }\end{array}$} \\
\hline JF-MG & $\begin{array}{l}\text { Anexo I item } \\
\text { 4.1.h }\end{array}$ & \multicolumn{4}{|c|}{$\begin{array}{l}\text { adotar soluções técnicas que considerem as disponibilidades } \\
\text { econômicas e financeiras para a implantação do } \\
\text { empreendimento. }\end{array}$} \\
\hline TRE-AL & PB item 6.j & \multicolumn{4}{|c|}{$\begin{array}{l}\text { Adoção de soluções técnicas que considerem as } \\
\text { disponibilidades econômicas e financeiras para a implantação } \\
\text { do edifício, observados os parâmetros legais de precificação de } \\
\text { obras públicas; }\end{array}$} \\
\hline TRE-PB & PB item V & \multicolumn{4}{|c|}{$\begin{array}{l}\text { adotar soluções técnicas que considerem as disponibilidades } \\
\text { econômicas e financeiras para a implantação do } \\
\text { empreendimento; }\end{array}$} \\
\hline UFTPR & PB item 4.d & \multicolumn{4}{|c|}{$\begin{array}{l}\text { A elaboração dos projetos deverá primar ainda pela } \\
\text { racionalização de custos e aproveitamento de recursos que } \\
\text { propiciem maximização de eficiência energética e menores } \\
\text { impactos ambientais, (...) }\end{array}$} \\
\hline
\end{tabular}


Quadro 02: Aspectos Socioeconômico - Custo de Ciclo de Vida / Modalidade Tomada de Preços

\begin{tabular}{|c|c|c|c|c|c|}
\hline \multicolumn{6}{|c|}{ SÍNTESE ACHADOS DE PESQUISA } \\
\hline Modalidade & $\begin{array}{l}\text { Tomada de } \\
\text { Preços }\end{array}$ & Categoria & $\begin{array}{c}\text { Aspectos } \\
\text { Socioeconômicos }\end{array}$ & Critério & $\begin{array}{c}\text { Custo de Ciclo } \\
\text { de Vida }\end{array}$ \\
\hline Entidade & $\begin{array}{l}\text { Localização } \\
\text { Instrumento } \\
\text { Licitatório }\end{array}$ & \multicolumn{4}{|c|}{ Conteúdo } \\
\hline CREA-PR & $\begin{array}{l}\text { PB item } \\
\text { II.13.i.ii.X }\end{array}$ & \multicolumn{4}{|c|}{$\begin{array}{l}\text { Aspectos econômicos quanto aos custos iniciais e de } \\
\text { manutenção. }\end{array}$} \\
\hline JF-GO & $\begin{array}{l}\text { Anexo I item } \\
4.1 .3\end{array}$ & \multicolumn{4}{|c|}{$\begin{array}{l}\text { considerar os requisitos de segurança, funcionalidade e } \\
\text { adequação ao interesse público, possibilidade de emprego de } \\
\text { mão de obra, materiais, tecnologia e matérias primas } \\
\text { existentes no local para execução, de modo a diminuir custos } \\
\text { de transporte; facilidade e economia na execução, conservação } \\
\text { e operação, sem prejuízo da durabilidade da obra ou do } \\
\text { serviço; }\end{array}$} \\
\hline JF-MG & $\begin{array}{l}\text { Anexo I item } \\
\text { 4.2.5.b }\end{array}$ & \multicolumn{4}{|c|}{$\begin{array}{l}\text { Adoção de materiais que sejam duráveis, não somente pelas } \\
\text { suas características técnicas, mas também em função do seu } \\
\text { desempenho e comportamento ao longo do tempo, o que } \\
\text { resulta em longevidade para o edifício. }\end{array}$} \\
\hline TRE-AL & PB item 6.h & \multicolumn{4}{|c|}{$\begin{array}{l}\text { A escolha dos materiais deverá levar em conta condições } \\
\text { ambientais, de manutenção e de conservação, dentre as quais } \\
\text { as consideradas abaixo: (...) Aspectos econômicos quanto aos } \\
\text { custos iniciais e de manutenção. }\end{array}$} \\
\hline TRE-PB & PB item V & \multicolumn{4}{|c|}{$\begin{array}{l}\text { os materiais e acabamentos a serem aplicados devem ser } \\
\text { discutidos e acordados com a Seção de Engenharia e } \\
\text { Arquitetura, tendo em vista o objetivo da padronização dos } \\
\text { materiais utilizados nos Fóruns Eleitorais, para fins de redução } \\
\text { dos custos com manutenção. }\end{array}$} \\
\hline
\end{tabular}


Quadro 03: Aspectos Socioeconômicos - Utilização de Mão de Obra Local / Modalidade Tomada de Preços

\begin{tabular}{|c|c|c|c|c|c|}
\hline \multicolumn{6}{|c|}{ SÍNTESE ACHADOS DE PESQUISA } \\
\hline Modalidade & $\begin{array}{l}\text { Tomada de } \\
\text { Preços }\end{array}$ & Categoria & $\begin{array}{c}\text { Aspectos } \\
\text { Socioeconômicos }\end{array}$ & Critério & $\begin{array}{l}\text { Utilização de mão } \\
\text { de obra local }\end{array}$ \\
\hline Entidade & $\begin{array}{l}\text { Localização } \\
\text { Instrumento } \\
\text { Licitatório } \\
\end{array}$ & \multicolumn{4}{|c|}{ Conteúdo } \\
\hline \multirow{2}{*}{ CREA-PR } & $\begin{array}{l}\text { PB item } \\
\text { II.13.i.ii.I }\end{array}$ & \multicolumn{4}{|c|}{$\begin{array}{l}\text { Técnicas construtivas adequadas à indústria, materiais e mão } \\
\text { de obra locais; }\end{array}$} \\
\hline & $\begin{array}{l}\text { PB item } \\
\text { Il.13.i.iii.V }\end{array}$ & \multicolumn{4}{|c|}{$\begin{array}{l}\text { As especificações de serviços deverão considerar: (...) } \\
\text { Disponibilidade de mão de obra. }\end{array}$} \\
\hline JF-GO & $\begin{array}{l}\text { Anexo I item } \\
4.1 .3\end{array}$ & \multicolumn{4}{|c|}{$\begin{array}{l}\text { considerar os requisitos de segurança, funcionalidade e } \\
\text { adequação ao interesse público, possibilidade de emprego de } \\
\text { mão de obra, materiais, tecnologia e matérias primas } \\
\text { existentes no local para execução (...) }\end{array}$} \\
\hline JF-MG & $\begin{array}{l}\text { Anexo I item } \\
\text { 4.1.c }\end{array}$ & \multicolumn{4}{|c|}{$\begin{array}{l}\text { considerar os requisitos de segurança, funcionalidade e } \\
\text { adequação ao interesse público, possibilidade de emprego de } \\
\text { mão de obra, materiais, tecnologia e matérias primas } \\
\text { existentes no local para execução (...) }\end{array}$} \\
\hline \multirow[t]{2}{*}{ TRE-AL } & $\begin{array}{l}\text { PB item } \\
\text { 10.8.2.a }\end{array}$ & \multicolumn{4}{|c|}{$\begin{array}{l}\text { A escolha dos materiais deverá levar em conta condições } \\
\text { ambientais, de manutenção e de conservação, dentre as quais } \\
\text { as consideradas abaixo - (...)Técnicas construtivas adequadas à } \\
\text { indústria, materiais e mão de obra locais; }\end{array}$} \\
\hline & $\begin{array}{l}\text { PB item } \\
\text { 10.8.3.e }\end{array}$ & \multicolumn{4}{|c|}{$\begin{array}{l}\text { As especificações de serviços deverão considerar: (...) } \\
\text { Disponibilidade de mão de obra. }\end{array}$} \\
\hline
\end{tabular}




\section{APÊNDICE J}

Quadro 01: Aspectos Técnicos - Operação eficiente / Modalidade Convite

\begin{tabular}{|c|c|c|c|c|c|}
\hline \multicolumn{6}{|c|}{ SÍNTESE ACHADOS DE PESQUISA } \\
\hline Modalidade & Convite & Categoria & $\begin{array}{l}\text { Aspectos } \\
\text { Técnicos }\end{array}$ & Critério & $\begin{array}{l}\text { Operação eficiente } \\
\text { empreendimento }\end{array}$ \\
\hline Entidade & $\begin{array}{c}\text { Localização } \\
\text { Instrumento } \\
\text { Licitatório }\end{array}$ & \multicolumn{4}{|c|}{ Conteúdo } \\
\hline CRF-PE & TR item 01 & \multicolumn{4}{|c|}{$\begin{array}{l}\text { Considerando que a futura sede do CRF-PE deve conter uma } \\
\text { infraestrutura moderna, econômica em termos operacionais e } \\
\text { de manutenção para atender todas as demandas compatíveis } \\
\text { com a finalidade institucional, abrigando todas as suas } \\
\text { unidades em um único imóvel. }\end{array}$} \\
\hline
\end{tabular}

Quadro 02: Aspectos Técnicos - Manutenção / Modalidade Convite

\begin{tabular}{|c|c|c|c|c|c|}
\hline \multicolumn{6}{|c|}{ SÍNTESE ACHADOS DE PESQUISA } \\
\hline Modalidade & Convite & Categoria & $\begin{array}{l}\text { Aspectos } \\
\text { Técnicos }\end{array}$ & Critério & Manutenabilidade \\
\hline Entidade & $\begin{array}{l}\text { Localização } \\
\text { Instrumento } \\
\text { Licitatório }\end{array}$ & \multicolumn{4}{|c|}{ Conteúdo } \\
\hline CRP-RN & PB item IV & \multicolumn{4}{|c|}{$\begin{array}{l}\text { O projeto deverá propor a flexibilidade, funcionalidade, } \\
\text { segurança institucional, economicidade, durabilidade e } \\
\text { manutenção não-dispendiosa. }\end{array}$} \\
\hline CRF-PE & TR item 01 & \multicolumn{4}{|c|}{$\begin{array}{l}\text { Considerando que a futura sede do CRF-PE deve conter uma } \\
\text { infraestrutura moderna, econômica em termos operacionais e } \\
\text { de manutenção para atender todas as demandas compatíveis } \\
\text { com a finalidade institucional, abrigando todas as suas } \\
\text { unidades em um único imóvel. }\end{array}$} \\
\hline
\end{tabular}




\section{APÊNDICE K}

Quadro 01: Aspectos Socioeconômicos - Custo da Construção (Economicidade) / Modalidade Convite

\begin{tabular}{|c|c|c|c|c|c|}
\hline \multicolumn{6}{|c|}{ SÍNTESE ACHADOS DE PESQUISA } \\
\hline Modalidade & Convite & Categoria & $\begin{array}{c}\text { Aspectos } \\
\text { Socioeconômicos }\end{array}$ & Critério & $\begin{array}{l}\text { Custo Construção } \\
\text { (economicidade) }\end{array}$ \\
\hline Entidade & \begin{tabular}{|c|} 
Localização \\
Instrumento \\
Licitatório \\
\end{tabular} & \multicolumn{4}{|c|}{ Conteúdo } \\
\hline CRP-RN & PB item IV & \multicolumn{4}{|c|}{$\begin{array}{l}\text { O projeto deverá propor a flexibilidade, funcionalidade, } \\
\text { segurança institucional, economicidade, durabilidade e } \\
\text { manutenção não-dispendiosa. }\end{array}$} \\
\hline FAPESP & $\begin{array}{l}\text { TR item } \\
\text { 7.1.1 }\end{array}$ & \multicolumn{4}{|c|}{$\begin{array}{l}\text { PROGRAMA DE NECESSIDADES (...) - Valor disponível para } \\
\text { execução da obra, móveis, de acordo com as premissas da } \\
\text { FAPESP e material permanente; }\end{array}$} \\
\hline FUNDAEPE & TR item VI.II & \multicolumn{4}{|c|}{$\begin{array}{l}\text { A elaboração do projeto deverá primar ainda pela racionalização } \\
\text { de custos e aproveitamento de recursos que propiciem } \\
\text { maximização de eficiência energética e menor impacto } \\
\text { ambiental. }\end{array}$} \\
\hline
\end{tabular}

Quadro 02: Aspectos Socioeconômicos - Custo de Ciclo de Vida / Modalidade Convite

\begin{tabular}{|c|c|c|c|c|c|}
\hline \multicolumn{6}{|c|}{ SÍNTESE ACHADOS DE PESQUISA } \\
\hline Modalidade & Convite & Categoria & $\begin{array}{c}\text { Aspectos } \\
\text { Socioeconômicos }\end{array}$ & Critério & $\begin{array}{c}\text { Custo de Ciclo de } \\
\text { Vida }\end{array}$ \\
\hline Entidade & $\begin{array}{l}\text { Localização } \\
\text { Instrumento } \\
\text { Licitatório }\end{array}$ & \multicolumn{4}{|c|}{ Conteúdo } \\
\hline CRP-RN & PB item IV & \multicolumn{4}{|c|}{$\begin{array}{l}\text { O projeto deverá propor a flexibilidade, funcionalidade, } \\
\text { segurança institucional, economicidade, durabilidade e } \\
\text { manutenção não-dispendiosa. }\end{array}$} \\
\hline
\end{tabular}




\section{APÊNDICE L}

Tabela Complementar Tipo 01 - Modalidade Concurso de Projeto

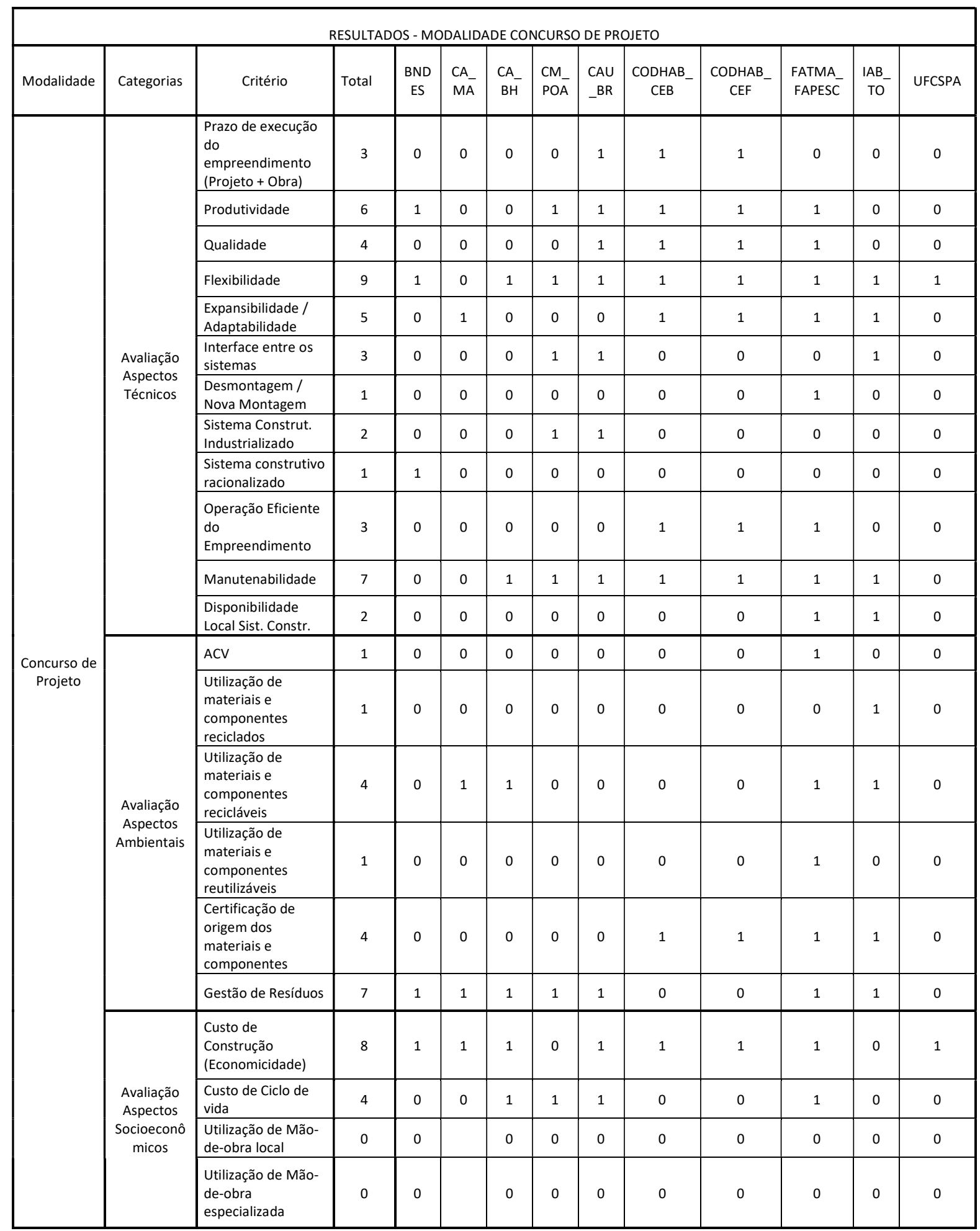




\section{APÊNDICE M}

Tabela Complementar Tipo 01 - Modalidade Concorrência

\begin{tabular}{|c|c|c|c|c|c|c|c|c|c|c|c|c|c|}
\hline & & & SULTA & OS - & MODAL & ADE CO & CORRÊ & $\mathrm{JCIA}$ & & & & & \\
\hline \multirow{19}{*}{ Concorrência } & \multirow{11}{*}{$\begin{array}{l}\text { Avaliação } \\
\text { Aspectos } \\
\text { Técnicos }\end{array}$} & Produtividade & 9 & 1 & 1 & 0 & 1 & 1 & 1 & 1 & 1 & 1 & 1 \\
\hline & & Qualidade & 3 & 0 & 1 & 0 & 0 & 0 & 1 & 1 & 0 & 0 & 0 \\
\hline & & Flexibilidade & 5 & 1 & 1 & 0 & 0 & 1 & 1 & 1 & 0 & 0 & 0 \\
\hline & & $\begin{array}{l}\text { Expansibilidade / } \\
\text { Adaptabilidade }\end{array}$ & 2 & 1 & 0 & 0 & 0 & 1 & 0 & 0 & 0 & 0 & 0 \\
\hline & & $\begin{array}{l}\text { Interface entre os } \\
\text { sistemas }\end{array}$ & 5 & 1 & 1 & 0 & 1 & 0 & 1 & 1 & 0 & 0 & 0 \\
\hline & & \begin{tabular}{|l|} 
Desmontagem / \\
Nova Montagem \\
\end{tabular} & 0 & 0 & 0 & 0 & 0 & 0 & 0 & 0 & 0 & 0 & 0 \\
\hline & & \begin{tabular}{|l|} 
Sistema Construt. \\
Industrializado \\
\end{tabular} & 2 & 0 & 1 & 0 & 0 & 1 & 0 & 0 & 0 & 0 & 0 \\
\hline & & $\begin{array}{l}\text { Sistema } \\
\text { construtivo } \\
\text { racionalizado } \\
\end{array}$ & 0 & 0 & 0 & 0 & 0 & 0 & 0 & 0 & 0 & 0 & 0 \\
\hline & & $\begin{array}{l}\text { Operação } \\
\text { Eficiente do } \\
\text { Empreendimento }\end{array}$ & 9 & 1 & 1 & 0 & 1 & 1 & 1 & 1 & 1 & 1 & 1 \\
\hline & & Manutenabilidade & 9 & 1 & 1 & 0 & 1 & 1 & 1 & 1 & 1 & 1 & 1 \\
\hline & & $\begin{array}{l}\text { Disponibilidade } \\
\text { Local Sist. Constr. }\end{array}$ & 1 & 0 & 1 & 0 & 0 & 0 & 0 & 0 & 0 & 0 & 0 \\
\hline & \multirow{4}{*}{$\begin{array}{l}\text { Avaliação } \\
\text { Aspectos } \\
\text { Ambientais }\end{array}$} & \begin{tabular}{|l} 
Utilização de \\
materiais e \\
componentes \\
recicláveis \\
\end{tabular} & 3 & 0 & 1 & 0 & 0 & 1 & 1 & 0 & 0 & 0 & 0 \\
\hline & & $\begin{array}{l}\text { Utilização de } \\
\text { materiais e } \\
\text { componentes } \\
\text { reutilizáveis } \\
\end{array}$ & 2 & 0 & 1 & 0 & 0 & 0 & 1 & 0 & 0 & 0 & 0 \\
\hline & & $\begin{array}{l}\text { Certificação de } \\
\text { origem dos } \\
\text { materiais e } \\
\text { componentes } \\
\end{array}$ & 2 & 0 & 0 & 1 & 0 & 1 & 0 & 0 & 0 & 0 & 0 \\
\hline & & $\begin{array}{l}\text { Gestão de } \\
\text { Resíduos } \\
\end{array}$ & 3 & 0 & 1 & 0 & 0 & 1 & 1 & 0 & 0 & 0 & 0 \\
\hline & \multirow{4}{*}{$\begin{array}{c}\text { Avaliação } \\
\text { Aspectos } \\
\text { Socioeconômicos }\end{array}$} & $\begin{array}{l}\text { Custo de } \\
\text { Construção } \\
\text { (Economicidade) }\end{array}$ & 9 & 1 & 1 & 0 & 1 & 1 & 1 & 1 & 1 & 1 & 1 \\
\hline & & $\begin{array}{l}\begin{array}{l}\text { Custo de Ciclo de } \\
\text { vida }\end{array} \\
\end{array}$ & 5 & 0 & 1 & 0 & 1 & 0 & 1 & 1 & 0 & 0 & 1 \\
\hline & & $\begin{array}{l}\text { Utilização de } \\
\text { Mão-de-obra } \\
\text { local } \\
\end{array}$ & 5 & 1 & 1 & 0 & 0 & 0 & 1 & 1 & 0 & 0 & 1 \\
\hline & & $\begin{array}{l}\text { Utilização de } \\
\text { Mão-de-obra } \\
\text { especializada }\end{array}$ & 0 & 0 & & 0 & 0 & 0 & 0 & 0 & 0 & 0 & 0 \\
\hline
\end{tabular}




\section{APÊNDICE N}

Tabela Complementar Tipo 01 - Modalidade Tomada Preço

\begin{tabular}{|c|c|c|c|c|c|c|c|c|c|c|c|c|c|}
\hline & & RESU & TADOS & MODAL & DADE TC & AADA DE & REÇOS & & & & & & \\
\hline Modalidade & Categorias & Critério & Total & $\begin{array}{l}\mathrm{CM}_{-} \\
\text {Cotia }\end{array}$ & $\begin{array}{c}\text { CREA- } \\
\text { PR }\end{array}$ & JF_GO & JF_MG & PISAC & $\begin{array}{l}\text { TRE } \\
-A L\end{array}$ & $\begin{array}{l}\text { TRE } \\
-P B\end{array}$ & $\begin{array}{l}\text { TRE } \\
-S P\end{array}$ & UFTPR & USP \\
\hline \multirow{22}{*}{$\begin{array}{l}\text { Concurso de } \\
\text { Projeto }\end{array}$} & \multirow{12}{*}{$\begin{array}{l}\text { Avaliação } \\
\text { Aspectos } \\
\text { Técnicos }\end{array}$} & $\begin{array}{l}\text { Prazo de } \\
\text { execução do } \\
\text { empreendimento } \\
\text { (Projeto + Obra) }\end{array}$ & 0 & 0 & 0 & 0 & 0 & 0 & 0 & 0 & 0 & 0 & 0 \\
\hline & & Produtividade & 7 & 0 & 1 & 1 & 1 & 1 & 1 & 1 & 0 & 1 & 0 \\
\hline & & Qualidade & 3 & 0 & 1 & 0 & 0 & 0 & 1 & 0 & 0 & 0 & 1 \\
\hline & & Flexibilidade & 4 & 0 & 0 & 1 & 1 & 1 & 1 & 0 & 0 & 0 & 0 \\
\hline & & $\begin{array}{l}\text { Expansibilidade / } \\
\text { Adaptabilidade }\end{array}$ & 3 & 0 & 0 & 1 & 1 & 0 & 0 & 0 & 0 & 0 & 1 \\
\hline & & $\begin{array}{l}\text { Interface entre os } \\
\text { sistemas }\end{array}$ & 6 & 0 & 1 & 1 & 1 & 1 & 1 & 0 & 0 & 1 & 0 \\
\hline & & $\begin{array}{l}\text { Desmontagem / } \\
\text { Nova Montagem }\end{array}$ & 0 & 0 & 0 & 0 & 0 & 0 & 0 & 0 & 0 & 0 & 0 \\
\hline & & $\begin{array}{l}\text { Sistema Construt. } \\
\text { Industrializado }\end{array}$ & 0 & 0 & 0 & 0 & 0 & 0 & 0 & 0 & 0 & 0 & 0 \\
\hline & & $\begin{array}{l}\text { Sistema } \\
\text { construtivo } \\
\text { racionalizado } \\
\end{array}$ & 0 & 0 & 0 & 0 & 0 & 0 & 0 & 0 & 0 & 0 & 0 \\
\hline & & $\begin{array}{l}\text { Operação } \\
\text { Eficiente do } \\
\text { Empreendimento }\end{array}$ & 8 & 0 & 1 & 1 & 1 & 1 & 1 & 1 & 1 & 0 & 1 \\
\hline & & $\begin{array}{l}\text { Manutenabilidad } \\
\text { e }\end{array}$ & 7 & 0 & 1 & 1 & 1 & 0 & 1 & 1 & 1 & 0 & 1 \\
\hline & & $\begin{array}{l}\text { Disponibilidade } \\
\text { Local Sist. Constr. }\end{array}$ & 4 & 0 & 1 & 1 & 1 & 0 & 1 & 0 & 0 & 0 & 0 \\
\hline & \multirow{6}{*}{$\begin{array}{l}\text { Avaliação } \\
\text { Aspectos } \\
\text { Ambientais }\end{array}$} & $\mathrm{ACV}$ & 4 & 0 & 1 & 1 & 1 & 0 & 1 & 0 & 0 & 0 & 0 \\
\hline & & $\begin{array}{l}\text { Utilização de } \\
\text { materiais e } \\
\text { componentes } \\
\text { reciclados }\end{array}$ & 0 & 0 & 0 & 0 & 0 & 0 & 0 & 0 & 0 & 0 & 0 \\
\hline & & $\begin{array}{l}\text { Utilização de } \\
\text { materiais e } \\
\text { componentes } \\
\text { recicláveis } \\
\end{array}$ & 2 & 0 & 0 & 1 & 1 & 0 & 0 & 0 & 0 & 0 & 0 \\
\hline & & $\begin{array}{l}\text { Utilização de } \\
\text { materiais e } \\
\text { componentes } \\
\text { reutilizáveis }\end{array}$ & 1 & 0 & 0 & 0 & 0 & 0 & 0 & 0 & 0 & 0 & 1 \\
\hline & & $\begin{array}{l}\text { Certificação de } \\
\text { origem dos } \\
\text { materiais e } \\
\text { componentes }\end{array}$ & 4 & 0 & 1 & 1 & 1 & 1 & 0 & 0 & 0 & 0 & 0 \\
\hline & & $\begin{array}{l}\text { Gestão de } \\
\text { Resíduos }\end{array}$ & 5 & 0 & 0 & 1 & 1 & 1 & 1 & 0 & 0 & 0 & 1 \\
\hline & \multirow{4}{*}{$\begin{array}{c}\text { Avaliação } \\
\text { Aspectos } \\
\text { Socioeconômi } \\
\text { cos }\end{array}$} & $\begin{array}{l}\text { Custo de } \\
\text { Construção } \\
\text { (Economicidade) }\end{array}$ & 7 & 1 & 1 & 1 & 1 & 0 & 1 & 1 & 0 & 1 & 0 \\
\hline & & $\begin{array}{l}\text { Custo de Ciclo de } \\
\text { vida }\end{array}$ & 5 & 0 & 1 & 1 & 1 & 0 & 1 & 1 & 0 & 0 & 0 \\
\hline & & $\begin{array}{l}\text { Utilização de } \\
\text { Mão-de-obra } \\
\text { local }\end{array}$ & 4 & 0 & 1 & 1 & 1 & 0 & 1 & 0 & 0 & 0 & 0 \\
\hline & & $\begin{array}{l}\text { Utilização de } \\
\text { Mão-de-obra } \\
\text { especializada }\end{array}$ & 0 & 0 & 0 & 0 & 0 & 0 & 0 & 0 & 0 & 0 & 0 \\
\hline
\end{tabular}




\section{APÊNDICE O}

Tabela Complementar Tipo 01 - Modalidade Convite

\begin{tabular}{|c|c|c|c|c|c|c|c|c|c|c|c|c|c|}
\hline & & & & RESUL & ADOS - M & DDALIDAL & E CONVIT & & & & & & \\
\hline $\begin{array}{c}\text { Modalida } \\
\text { de }\end{array}$ & Categorias & Critério & $\begin{array}{c}\text { Tota } \\
\mathrm{I}\end{array}$ & CFF8 & $\begin{array}{c}\text { CM_Ca } \\
\text { nitar }\end{array}$ & $\begin{array}{l}\text { CM_V } \\
\text { Nova }\end{array}$ & $\begin{array}{c}\mathrm{CRECl}_{-} \\
\mathrm{MG}\end{array}$ & $\begin{array}{l}\text { CREF } \\
9 \\
\end{array}$ & $\begin{array}{c}\mathrm{CRF}_{-} \\
\mathrm{GO}^{-}\end{array}$ & CRF_PE & $\begin{array}{l}\text { CRP } \\
\text { RN } \\
\end{array}$ & FAPESP & $\begin{array}{c}\text { FUNDAE } \\
\text { PE }\end{array}$ \\
\hline \multirow{12}{*}{\multicolumn{2}{|c|}{$\begin{array}{l}\text { Avaliação } \\
\text { Aspectos } \\
\text { Técnicos }\end{array}$}} & $\begin{array}{l}\text { Prazo de } \\
\text { execução do } \\
\text { empreendime } \\
\text { nto (Projeto + } \\
\text { Obra) }\end{array}$ & 0 & 0 & 0 & 0 & 0 & 0 & 0 & 0 & 0 & 0 & 0 \\
\hline & & Produtividade & 0 & 0 & 0 & 0 & 0 & 0 & 0 & 0 & 0 & 0 & 0 \\
\hline & & Qualidade & 0 & 0 & 0 & 0 & 0 & 0 & 0 & 0 & 0 & 0 & 0 \\
\hline & & Flexibilidade & 1 & 0 & 0 & 0 & 0 & 0 & 0 & 0 & 1 & 0 & 0 \\
\hline & & $\begin{array}{l}\text { Expansibilidad } \\
\text { e / } \\
\text { Adaptabilidade }\end{array}$ & 0 & 0 & 0 & 0 & 0 & 0 & 0 & 0 & 0 & 0 & 0 \\
\hline & & $\begin{array}{l}\text { Interface entre } \\
\text { os sistemas }\end{array}$ & 0 & 0 & 0 & 0 & 0 & 0 & 0 & 0 & 0 & 0 & 0 \\
\hline & & $\begin{array}{l}\text { Desmontagem } \\
\text { / Nova } \\
\text { Montagem }\end{array}$ & 0 & 0 & 0 & 0 & 0 & 0 & 0 & 0 & 0 & 0 & 0 \\
\hline & & $\begin{array}{l}\text { Sistema } \\
\text { Construt. } \\
\text { Industrializado }\end{array}$ & 0 & 0 & 0 & 0 & 0 & 0 & 0 & 0 & 0 & 0 & 0 \\
\hline & & $\begin{array}{l}\text { Sistema } \\
\text { construtivo } \\
\text { racionalizado }\end{array}$ & 0 & 0 & 0 & 0 & 0 & 0 & 0 & 0 & 0 & 0 & 0 \\
\hline & & $\begin{array}{l}\text { Operação } \\
\text { Eficiente do } \\
\text { Empreendime } \\
\text { nto }\end{array}$ & 1 & 0 & 0 & 0 & 0 & 0 & 0 & 1 & 0 & 0 & 0 \\
\hline & & $\begin{array}{l}\text { Manutenabilid } \\
\text { ade } \\
\end{array}$ & 2 & 0 & 0 & 0 & 0 & 0 & 0 & 1 & 1 & 0 & 0 \\
\hline & & $\begin{array}{l}\text { Disponibilidad } \\
\text { e Local Sist. } \\
\text { Constr. } \\
\end{array}$ & 0 & 0 & 0 & 0 & 0 & 0 & 0 & 0 & 0 & 0 & 0 \\
\hline & \multirow{6}{*}{$\begin{array}{c}\text { Avaliação } \\
\text { Aspectos } \\
\text { Ambientais }\end{array}$} & $\mathrm{ACV}$ & 0 & 0 & 0 & 0 & 0 & 0 & 0 & 0 & 0 & 0 & 0 \\
\hline & & $\begin{array}{l}\text { Utilização de } \\
\text { materiais e } \\
\text { componentes } \\
\text { reciclados }\end{array}$ & 0 & 0 & 0 & 0 & 0 & 0 & 0 & 0 & 0 & 0 & 0 \\
\hline & & $\begin{array}{l}\text { Utilização de } \\
\text { materiais e } \\
\text { componentes } \\
\text { recicláveis }\end{array}$ & 0 & 0 & 0 & 0 & 0 & 0 & 0 & 0 & 0 & 0 & 0 \\
\hline & & $\begin{array}{l}\text { Utilização de } \\
\text { materiais e } \\
\text { componentes } \\
\text { reutilizáveis } \\
\end{array}$ & 0 & 0 & 0 & 0 & 0 & 0 & 0 & 0 & 0 & 0 & 0 \\
\hline & & $\begin{array}{l}\text { Certificação de } \\
\text { origem dos } \\
\text { materiais e } \\
\text { componentes } \\
\end{array}$ & 0 & 0 & 0 & 0 & 0 & 0 & 0 & 0 & 0 & 0 & 0 \\
\hline & & $\begin{array}{l}\text { Gestão de } \\
\text { Resíduos }\end{array}$ & 0 & 0 & 0 & 0 & 0 & 0 & 0 & 0 & 0 & 0 & 0 \\
\hline & \multirow{4}{*}{$\begin{array}{c}\text { Avaliação } \\
\text { Aspectos } \\
\text { Socioeconômi } \\
\text { cos }\end{array}$} & $\begin{array}{l}\text { Custo de } \\
\text { Construção } \\
\text { (Economicidad } \\
\text { e) } \\
\end{array}$ & 3 & 0 & 0 & 0 & 0 & 0 & 0 & 0 & 1 & 1 & 1 \\
\hline & & \begin{tabular}{|l|} 
Custo de Ciclo \\
de vida \\
\end{tabular} & 1 & 0 & 0 & 0 & 0 & 0 & 0 & 0 & 1 & 0 & 0 \\
\hline & & $\begin{array}{l}\text { Utilização de } \\
\text { Mão-de-obra } \\
\text { local }\end{array}$ & 0 & 0 & 0 & 0 & 0 & 0 & 0 & 0 & 0 & 0 & 0 \\
\hline & & $\begin{array}{l}\text { Utilização de } \\
\text { Mão-de-obra } \\
\text { especializada }\end{array}$ & 0 & 0 & 0 & 0 & 0 & 0 & 0 & 0 & 0 & 0 & 0 \\
\hline
\end{tabular}




\section{APÊNDICE P}

Tabela Complementar Tipo 02 - Comparativo entre Modalidades

\begin{tabular}{|c|c|c|c|c|c|c|c|}
\hline \multicolumn{8}{|c|}{ Comparativo entre Modalidades } \\
\hline Categorias & Critério & Concorrência & \begin{tabular}{|c|}
$\begin{array}{c}\text { Concurso de } \\
\text { Projeto }\end{array}$ \\
\end{tabular} & $\begin{array}{c}\text { Tomada de } \\
\text { Preços }\end{array}$ & Convite & MÉDIA & $\begin{array}{l}\text { DESVIO } \\
\text { PADRÃO }\end{array}$ \\
\hline \multirow{12}{*}{$\begin{array}{l}\text { Avaliação } \\
\text { Aspectos } \\
\text { Técnicos }\end{array}$} & $\begin{array}{l}\text { Prazo de execução do } \\
\text { empreendimento (Projeto + } \\
\text { Obra) }\end{array}$ & 4 & 3 & 0 & 0 & 1,75 & 2,062 \\
\hline & Produtividade & 9 & 6 & 7 & 0 & 4,33 & 3,873 \\
\hline & Qualidade & 3 & 4 & 3 & 0 & 2,33 & 1,732 \\
\hline & Flexibilidade & 5 & 9 & 4 & 1 & 4,67 & 3,304 \\
\hline & $\begin{array}{l}\text { Expansibilidade / } \\
\text { Adaptabilidade }\end{array}$ & 2 & 5 & 3 & 0 & 2,67 & 2,082 \\
\hline & Interface entre os sistemas & 5 & 3 & 6 & 0 & 3,00 & 2,646 \\
\hline & $\begin{array}{l}\text { Desmontagem / Nova } \\
\text { Montagem }\end{array}$ & 0 & 1 & 0 & 0 & 0,33 & 0,500 \\
\hline & $\begin{array}{l}\text { Sistema Construt. } \\
\text { Industrializado }\end{array}$ & 2 & 2 & 0 & 0 & 0,67 & 1,155 \\
\hline & $\begin{array}{l}\text { Sistema construtivo } \\
\text { racionalizado }\end{array}$ & 0 & 1 & 0 & 0 & 0,33 & 0,500 \\
\hline & $\begin{array}{l}\text { Operação Eficiente do } \\
\text { Empreendimento }\end{array}$ & 9 & 3 & 8 & 1 & 4,00 & 3,862 \\
\hline & Manutenção & 9 & 7 & 7 & 2 & 5,33 & 2,986 \\
\hline & $\begin{array}{l}\text { Disponibilidade Local } \\
\text { Sistemas Construtivos }\end{array}$ & 1 & 2 & 4 & 0 & 2,00 & 1,708 \\
\hline \multirow{6}{*}{$\begin{array}{l}\text { Avaliação } \\
\text { Aspectos } \\
\text { Ambientais }\end{array}$} & ACV & 3 & 1 & 4 & 0 & 1,67 & 1,826 \\
\hline & $\begin{array}{l}\text { Utilização de materiais e } \\
\text { componentes reciclados }\end{array}$ & 1 & 1 & 0 & 0 & 0,33 & 0,577 \\
\hline & $\begin{array}{l}\text { Utilização de materiais e } \\
\text { componentes recicláveis }\end{array}$ & 3 & 4 & 2 & 0 & 2,00 & 1,708 \\
\hline & $\begin{array}{l}\text { Utilização de materiais e } \\
\text { componentes reutilizáveis }\end{array}$ & 2 & 1 & 1 & 0 & 0,67 & 0,816 \\
\hline & $\begin{array}{l}\text { Certificação de origem dos } \\
\text { materiais e componentes }\end{array}$ & 2 & 4 & 4 & 0 & 2,67 & 1,915 \\
\hline & Gestão de Resíduos & 3 & 7 & 5 & 0 & 4,00 & 2,986 \\
\hline \multirow{4}{*}{$\begin{array}{c}\text { Avaliação } \\
\text { Aspectos } \\
\text { Socioeconômicos }\end{array}$} & $\begin{array}{l}\text { Custo de Construção } \\
\text { (Economicidade) }\end{array}$ & 9 & 8 & 7 & 3 & 6,00 & 2,630 \\
\hline & Custo de Ciclo de vida & 5 & 3 & 5 & 1 & 3 & 1,915 \\
\hline & $\begin{array}{l}\text { Utilização de Mão-de-obra } \\
\text { local }\end{array}$ & 5 & 0 & 4 & 0 & 1,33 & 2,630 \\
\hline & $\begin{array}{l}\text { Utilização de Mão-de-obra } \\
\text { especializada }\end{array}$ & 0 & 0 & 0 & 0 & 0 & 0,000 \\
\hline
\end{tabular}

